FACULDADE DE FILOSOFIA, LETRAS E CIÊNCIAS HUMANAS.

DEPARTAMENTO DE ANTROPOLOGIA.

PROGRAMA DE PÓS-GRADUAÇÃO EM ANTROPOLOGIA SOCIAL.

\title{
A mãe-preta na literatura brasileira: a ambigüidade como construção social (1880-1950)
}

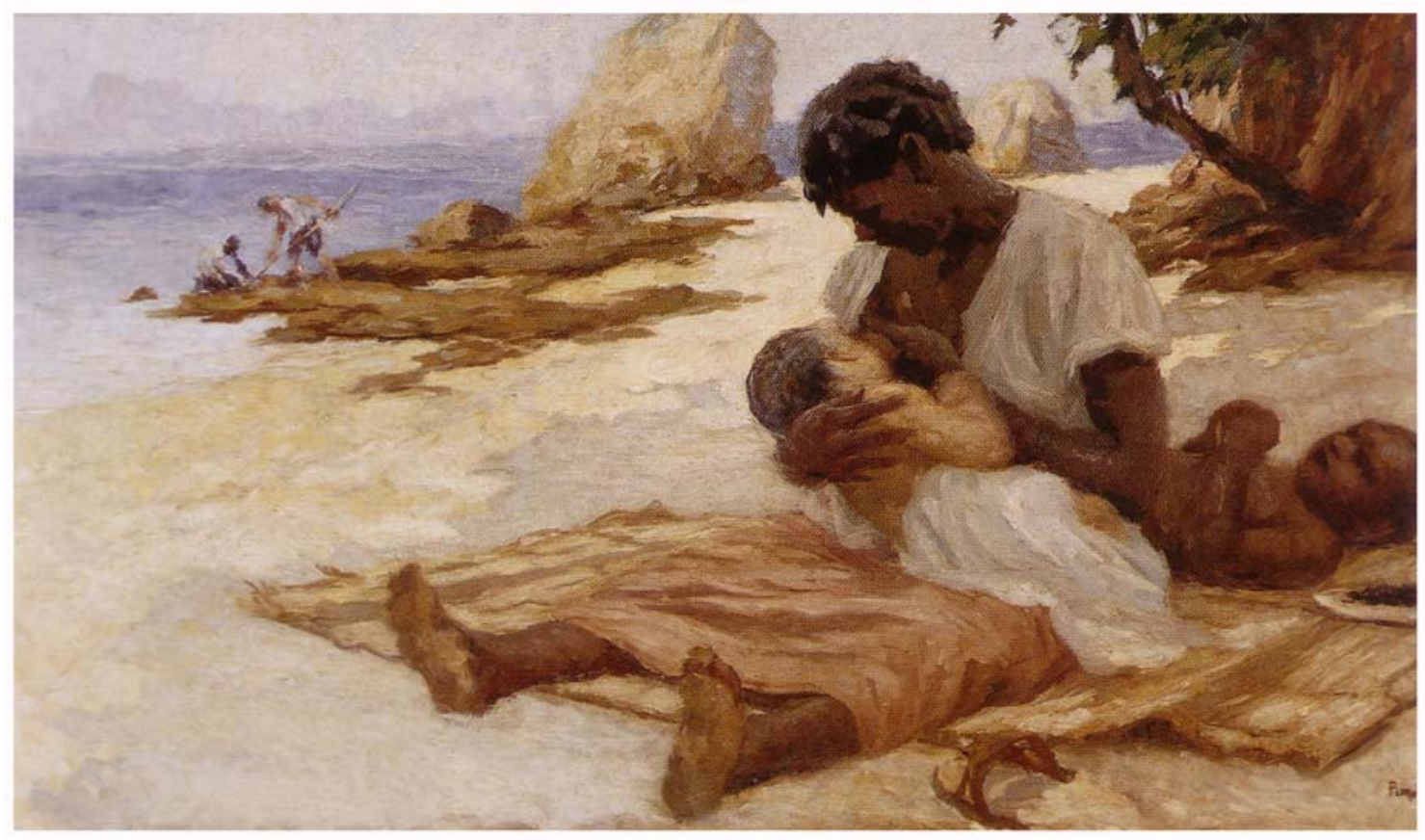

\section{Rafaela de Andrade Deiab}

Dissertação de Mestrado apresentada ao Programa de PósGraduação em Antropologia Social, do Departamento de Antropologia da Faculdade de Filosofia, Letras e Ciências Humanas da Universidade de São Paulo, para obtenção do título de Mestre em Antropologia Social

Orientadora: $\operatorname{Prof}^{\mathrm{a}} \operatorname{Dr}^{\mathrm{a}}$ Lilia Katri Moritz Schwarcz 


\author{
UNIVERSIDADE DE SÃO PAULO. \\ FACULDADE DE FILOSOFIA, LETRAS E CIÊNCIAS HUMANAS. \\ DEPARTAMENTO DE ANTROPOLOGIA. \\ PROGRAMA DE PÓS-GRADUAÇÃO EM ANTROPOLOGIA SOCIAL.
}

\title{
A mãe-preta na literatura brasileira: a ambigüidade como construção social (1880-1950)
}

\author{
Rafaela de Andrade Deiab
}


Ao Vovô Toninho (in memoriam) pela lição de amor incondicional... 
COMO SE FOSSE BALANÇO

"Lá se foi a primeira metade do ano, e já estamos folgados na segunda metade. Agosto continua o quê? Julho deu para balanço? Você fez alguma coisa do que planejava fazer neste ano? Claro que não. Fez, no máximo, aquilo que deixaram ou quiseram que você fizesse". (Carlos Drummond de Andrade, Os dias lindos).

Procurar epígrafe, estabelecer a ordem dos argumentos, ter todos os livros por perto, advertir as pessoas queridas (que podem querer te dissuadir de seus objetivos) de que pelos próximos anos você não estará tão disponível... Esses são pequenos exemplos dos procedimentos "rituais” para a realização de um "Mestrado". Sempre causa apreensão o começo de sua escritura, talvez porque ele deva sintetizar o que foram esses dois anos e meio de trabalho repleto de aprendizado, amadurecimento e realizações; mas também de limitações.

Essa apreensão já está acabando junto com esses agradecimentos... E o problema agora é conseguir encontrar as palavras adequadas para agradecer as muitas, mais muitas mesmo, pessoas que me ajudaram nessa empreitada de longa duração. Como já disse Drummond: “julho deu para balanço”, e estou a me lembrar dos variados momentos em que essa vastidão de gente me ajudou. Queria que essa parte do trabalho não se parecesse com uma nominata impessoal. Farei o possível para que isso não aconteça, porém, continuo a duvidar de minhas "capacidades literárias”.

Primeiramente, agradeço à Fapesp pelo suporte financeiro sem o qual a concretização desse trabalho realmente não seria possível.

Sou grata, também, aos funcionários das bibliotecas e arquivos (Museu Paulista, Biblioteca Mário de Andrade, Instituto de Estudos Brasileiros, Biblioteca Nacional, Biblioteca Florestan Fernandes) que freqüentei, os quais certamente tiveram um papel capital para essa dissertação.

Os funcionários do Departamento de Antropologia (Celso, Edinaldo, Ivanete, Rose e Soraia) sempre me ajudaram muito, esclarecendo as minhas dúvidas sobre a burocracia uspiana.

Muitos professores do meu curso de Ciências Sociais contribuíram para a concretização dessa pesquisa, que é, igualmente, o resultado de uma escolha de vida. Acho que se não fosse pela paciência da Prof ${ }^{\mathrm{a}}$ Sylvia Garcia, no início da graduação, eu não teria continuado o curso. Ela realmente me ensinou a ser aluna dessa Faculdade, iniciando-me nas coisas mais básicas e importantes da vida intelectual: "ler" e "fichar". A Prof ${ }^{\mathrm{a}}$ Maria Arminda, desde as primeiras disciplinas, despertou-me o interesse pelo estudo do "pensamento brasileiro" e da "cultura 
brasileira”, temas que continuo a estudar. O Prof. José Guilherme Magnani, em suas matérias e nas “conversas de corredor”, sempre tinha palavras de incentivo.

Na pós-graduação, Sergio Miceli, Julio Simões e Ana Claudia contribuíram muito para essa discussão por meio de suas disciplinas e indicações bibliográficas.

À Prof ${ }^{\mathrm{a}}$ Maria Lucia Montes e à Prof $^{\mathrm{a}}$ Fernanda Peixoto tenho de agradecer pela participação na Banca de Qualificação. Seus comentários foram realmente o "turning point” dessa pesquisa, e espero tê-los incorporado de maneira adequada. A “Fernandinha”, além de integrante da banca, foi uma das melhores professoras que já tive. Suas aulas eram divertidas, suas leituras profundas e provocantes, e sua companhia incrivelmente estimulante.

A minha querida orientadora, Lilia Moritz Schwarcz, é realmente difícil agradecer. Há pessoas que possuem autonomia intelectual e conseguem escrever uma dissertação de mestrado quase sozinhas. Esse não foi o meu caso, se não fossem as suas críticas, leituras e comentários essa dissertação não existiria. Nós estamos juntas nessa “jornada intelectual” desde o meu segundo ano de faculdade, quando me tornei sua orientanda de Iniciação Científica. Com ela aprendi verdadeiramente tudo sobre a vida acadêmica: desde como se faz pesquisa, se escreve relatório, se prepara trabalhos para congressos e etc. Para mim, é motivo de muito orgulho toda a paciência que ela sempre teve comigo, as palavras de incentivo, as críticas duras e as madrugadas que passou corrigindo essa dissertação. As incorreções que permanecem são, contudo, falhas minhas. Sua capacidade de trabalho, eficiência e qualidade de produção sempre foram inspiradoras. Mas a felicidade maior é pensar que fui orientada justamente pela professora que me revelou os verdadeiros sentidos da Antropologia. O “mantra” - "estudar o outro para entender a si” - continua atuante e mudando outras pessoas, como mudou a mim.

Dentre os amigos, tenho de agradecer aqueles que acompanham minha trajetória desde os tempos de colégio: Cau, Lu, Rafa Costa, Cris, Dani, Thaís (a primeira mamãe da turma), Carlinha (minha companhia perene, que também esteve comigo nesses oito anos de USP) e Carolzinha. Ela, em pleno “julho mês de balanço”, quando eu ainda titubeava em pedir prorrogação, me disse, com aquele jeito que é só seu: "Rafa, termina logo com isso. Eu tenho vários amigos que entraram e estão no mestrado, mas nenhum que saiu... parece até buraco negro... Termina logo!... nada de prorrogação!”. Viu só Carol, obedeci!

Não posso deixar de mencionar os amigos cinematográficos - Gui e Clara - que a Carlinha me legou. Se eu fazia figuração em seus trabalhos de conclusão de curso (que se tratavam, na verdade, de exercícios em película), eles foram quase protagonistas nas 
considerações finais desse trabalho. A Clara realizou as filmagens da Missa da Mãe Negra e o Guili é o autor da belíssima fotografia presente na parte final da dissertação.

Os amigos da Pós-Graduação foram imprescindíveis para fazer dessa jornada intelectual um ofício menos solitário. Lembro-me especialmente de Luciana, Isadora, Maíra Volpe, Rachel, Isabela, Dani, Érica e Cecília. As últimas cinco também são minhas companheiras no corpo editorial da Cadernos de Campo - Revista dos Alunos de Pós-Graduação em Antropologia Social da USP, o que fez com que a amizade e o trabalho se interpenetrassem ainda mais

Íris e Du são companheiros desde os tempos da graduação, quando já partilhávamos a mesma orientadora. Desde então, nossas relações se estreitaram cada vez mais, deixando em mim uma certeza profunda: um bom trabalho só se faz com amizade e companheirismo; e isso eu sempre encontrei de sobra em vocês dois.

A dívida para com as “cidadãs” da república - “A Casa das Sete Mulheres” - que habito é realmente incomensurável. Wania, Lídia, Aluani, Naty, Leane e Pauleca tiveram, por meses, a sala de casa loteada por meus livros, anotações, computador e cópias. “Cobriam” as minhas falhas domésticas e me acompanhavam nas jornadas noite adentro para o cumprimento dos prazos. Na reta final, foi inevitável trazê-las para o trabalho: a Lu ajudou a montar as cópias da dissertação; a Lê virou consultora de vírgulas, digitadora oficial e "help-desk”; já a Pauleca me alimentava e palpitava na redação nos momentos em que eu só escrevia... além de fazer os “animadores” cafés na calada da noite.

Os amigos queridos Francine, Miguel, Isabel, Bruna, Rafael, Joana, Renata, Helder e Ninha me acompanharam de perto na escritura desse trabalho; tanto nos períodos de "labuta esfalfante" diante dos livros, como nos momentos de divertimento e alegria que vivemos junto. Eles são parte importante desse processo de amadurecimento da pesquisadora e da pessoa que me tornei. A Jô é companheira de “boteco” e malhação, além de leitora de meu trabalho; a Isabel foi minha cicerone nas viagens para o Rio, além de ter feito a revisão do meu “abstract”. O Rafa é um grande amigo, além de um interlocutor importante a quem devo a lembrança de Louis Dumont. A Rê e o Helder, meu casal, são meu paradigma de intelectuais de sucesso, além de pessoas maravilhosas. Ela é minha companheira desde os tempos de graduação, amiga dileta, além de leitora exigente de meus textos. Mesmo longe, continua impressionantemente presente. A Ninha é antropóloga, mas essa é apenas uma dentre tantas afinidades que temos e que consolidaram uma amizade para toda a vida.

Ao João também faltam palavras para expressar o quanto lhe devo. Ele me acompanha desde a Iniciação Científica, corrigindo meus textos (aliás, com um prazer “sádico” em por as 
crases que esqueci), “scanneando” minhas imagens, apontando minhas imprecisões historiográficas, além de oferecer seu ombro amigo de maneira incondicional. Por meio dele fiz muitos outros amigos que fizeram desse mestrado uma aventura "nefanda", refiro-me ao Max, Vinícius, Du, Érico, Aline e Diogo.

O Kleber é, literalmente, o meu herói. Ele “encarou” começar a namorar uma garota em plena escritura do mestrado e acabou extremamente envolvido com o trabalho: digitou, corrigiu, palpitou e desenvolveu toda uma filosofia sobre a "formatação da dissertação". Resumindo o que não dá para resumir, não poderia ter sido mais perfeito.

Com a minha família os débitos são imensos. Meus irmãos Tici e Thiago acompanharam com curiosidade as peripécias da “exótica irmã”, que se embrenhava pelo campo da Antropologia. Minhas avós, Aline e Gláucia, sempre torceram e rezaram muito pela netinha. Quando nos falávamos, invariavelmente perguntavam como andava a “escola”. Minha mãe, Nara, e meu pai, Moises, foram a torcida mais constante que tive durante esse mestrado. Ainda que estranhassem ter uma filha antropóloga, foram aos poucos aderindo ao projeto. Minha mãe pediu para que eu fizesse "uma colinha” com meu tema de pesquisa para que ela, orgulhosa, pudesse contar aos outros o que a filhota estudava. No fim do trabalho acabou, também, "consultora de vírgulas”. Meu pai, ainda que reclamasse da ausência da filha, deu sempre todo o apoio para que realizasse meu trabalho. Queridos, obrigado por tudo, sobretudo pela chance que me deram, me tornar uma antropóloga muito contente com a escolha que fiz. 


\title{
RESUMO
}

Esta pesquisa tem como objetivo estudar a memória coletiva que se consolida em torno da figura da mãe-preta. Para a realização dessa empreitada, tomei como objeto de estudo as representações literárias da mãe-preta no período de 1880 a 1950. É nesse intervalo de tempo que se estabiliza uma interpretação mais alentada sobre a escravidão. Nessa medida, as representações da mãe-preta são tomadas como vias de acesso a interpretações paradoxais sobre a escravidão brasileira e seu legado. Tenho como hipótese que, se essa instituição violenta e arbitrária não podia ser esquecida; ela, ao menos, poderia ser lembrada em sua faceta mais íntima, afetiva e "produtora de uma cultura mestiça”. Contudo, ainda assim, afeto e intimidade parecem não conseguir romper com a diferença e a hierarquia social: é justamente nessa tensão que se constroem representações ambíguas da mãe-preta na literatura brasileira.

\section{PALAVRas-Chave:}

Mãe-preta ; Literatura ; Representação ; Escravidão ; Relações Raciais.

\begin{abstract}
The main purpose of this research is to study the collective memory formed around the figure of "mãe-preta" (black-mom). For this purpose, I have taken as object of study the literary representations of "mãe-preta" (black-mom) between 1880 and 1950. This is the main period in which an interpretation of slavery was established. Therefore, the representations of "mãe-preta" (black-mom) are a way of having access to the paradoxical interpretations of Brazilian slavery and its legacy. My hypothesis is that, although this violent and arbitrary institution could not be forgotten, it could at least be remembered in its more intimate and affective ways or as a "producer of a mixed culture". Nevertheless, it seems that intimacy and affection are not capable of breaking up with social difference and hierarchy. Ambiguous representations of "mãe-preta”" (black-mom) in Brazilian literature are built exactly on this tension.
\end{abstract}

\section{KEY-WORDS:}

“Mãe-preta” (black-mom) ; Literature ; Representation ; Slavery ; Racial Relations. 


\section{SUMÁRIO}

Introdução

Ama-de leite: da história rumo à memória

Parte I

Capítulo 1

Mãe-Preta: metáfora de uma discussão valorativa da escravidão $\quad 27$

Introdução $\quad 27$

Retratos: qualificativos para a relação mãe-preta de filho branco 27

A mãe-preta e a historiografia da escravidão 35

Capítulo 2

Versões brancas da mãe-preta 51

A heterogeneidade do material $\quad 51$

O negro e a mãe-preta na literatura brasileira 53

$\begin{array}{ll}\text { A mãe-preta na literatura infantil brasileira } & 67\end{array}$

\section{Parte II}

Capítulo 3

Representações da mãe-preta: delineamento e contrastes 85

$\begin{array}{ll}\text { Introdução } & 85\end{array}$

Mãe-preta de filho-branco $\quad 85$

Mãe-preta e as nuances da escravidão 103

Mãe-preta de filho preto $\quad 111$

Mãe-preta versus mãe escrava $\quad 118$

Mãe-preta e a magia $\quad 124$

Mãe-preta e Pai-joão: personagens simétricos 127

Mãe-preta e o sacrifício pela pátria $\quad 135$

$\begin{array}{ll}\text { O legado da mãe-preta e da escravidão } & 140\end{array}$

Capítulo 4

Diversos sentidos da mãe-preta na literatura infantil brasileira $\quad 144$ Introdução 144

“Negras velhas” contadoras de histórias 145

"Negras velhas” cozinheiras e agregadas da família 162

“Negras velhas” são o “Povo” 183 
Fontes
Anexo
a) Imagem
b) Fontes 
“As tradições pátrias, a poesia popular, todo o nosso folclore, que é a representação emotiva mais genuína da nossa gente e nacionalidade, as velhas pretas, as mucamas, os negros velhos, contadores de histórias e dizedores de crendices e lendas, o transmitiam às suas senhoras-moças e nhanhãs e sinhozinhos, e com elas alguma coisa da própria alma da pátria. Conservando-se às vêzes nas famílias por gerações, passando de avós e netos, guardavam os escravos as tradições das casas, as histórias das famílias, e as transmitiam de geração em geração, de um ramo a outro. Êstes elos, estes fonogramas vivos das tradições familiares, que a sua poesia nativa, bruta, mas comovida, alterava, adulterava, mas freqüentemente também embelecia idealizando-a, e que serviam para manter em cada família brasileira a continuidade das tradições domésticas e de estabelecer entre elas e a terra e a gente, das quais a sua fortuna e posição acaso os afastava, a corrente de contacto e simpatia necessária à persistência e desenvolvimento do sentimento nacional, êstes agentes de comunicação desapareceram com a escravidão.”

\section{José Veríssimo ${ }^{1}$}

\footnotetext{
1 José Veríssimo. A Educação Nacional. Porto Alegre, Mercado Aberto Editoras, 1985.
} 


\section{INTRODUÇÃO}

\section{Ama-de-leite: da história rumo à memória}

"A imagem de uma união paradoxal mas admitida. Uma união fundada no amor presente e na violência pregressa. Na violência que fendeu a alma escrava, abrindo espaço afetivo que está sendo invadido pelo filho do senhor. Quase todo Brasil cabe nessa foto.”1

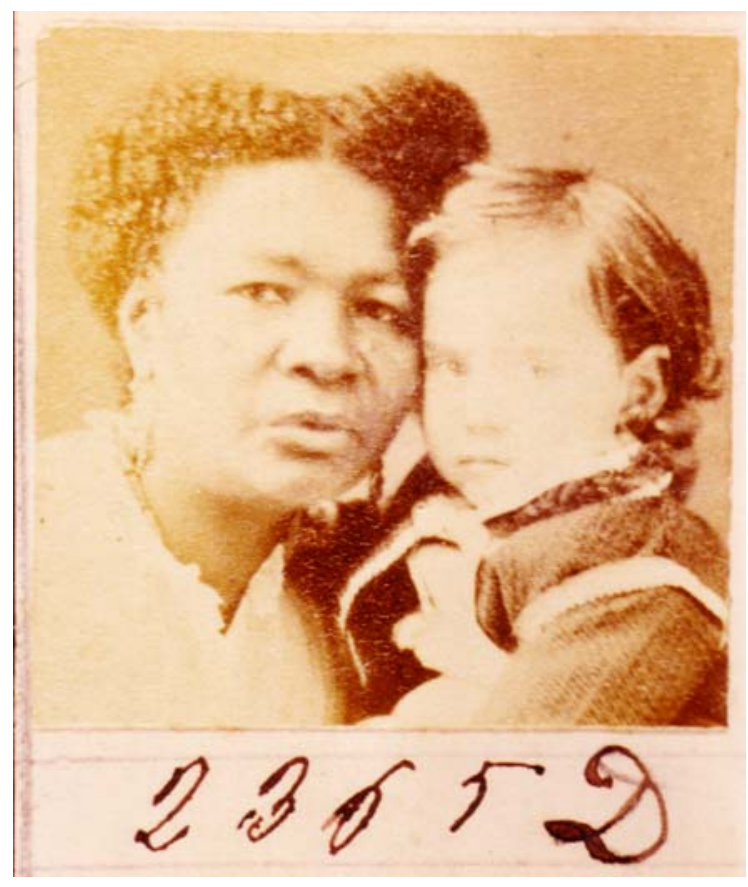

[FIGURA 1 - MILITÃO 1870]

A ama negra e a criança branca posam bem juntinhas, de rostos colados nesse retrato construído para a posteridade. Ambos estão ricamente produzidos. Ela, uma senhora já madura, tem os volumosos cabelos arrumados, repartidos ao meio - conforme ditava a moda francesa - e presos, sem nenhum fio sequer fora do arranjo. Traz brincos grandes nas orelhas e uma roupa bem cortada, com gola alta de babado ou renda. A criança alourada, também está com os cabelos penteados, repartidos com a franja trazida para o lado, vestida com uma camisa e um casaquinho cheio de detalhes. Atrás deles, ao fundo, há um painel-cenário cinza, dando ainda mais destaque aos personagens, ambos em primeiro plano. Esse retrato traz à tona o objeto dessa dissertação: as diferentes representações da mãe-preta, termo esse que só faz sentido diante de sua contrapartida, o filho branco. Trata-se, assim, não de um termo isolado, mas de uma relação.

\footnotetext{
${ }^{1}$ Luiz Felipe de Alencastro. "Epílogo” in: História da vida privada no Brasil - volume 2. São Paulo, Companhia das Letras, 1997/ 2002. p. 440. p.52.
} 
Essas diversas representações da mãe-preta surgem de uma relação social empírica e determinada, que existiu entre a ama negra e os herdeiros da família patriarcal. No entanto, finda a escravidão, e rareando essas mães-pretas “históricas”, suas representações continuam por muito tempo ainda ativas, e sendo constantemente reelaboradas. E é justamente sobre essas diversas representações - sejam aquelas concomitantes a sua existência enquanto figura histórica, ou aquelas descoladas dessa empiria, e pertencentes a uma memória coletiva - que me detenho nesse trabalho.

Seguindo essa lógica, o retrato-epígrafe trataria justamente daquelas representações da mãe-preta simultâneas a sua existência histórica. Isso de modo paradigmático, porque a fotografia, sobretudo na sua forma oitocentista de retrato de estúdio, constitui-se ao mesmo tempo como documento e representação, desse vínculo social tecido entre as escravas e as crianças brancas.

A fotografia, entendida enquanto "traço do real”, atesta somente a existência no passado daquilo que ela mostra²: a mãe-preta escrava e o seu filho branco estiveram lá, bem próximos, diante do fotógrafo, que os fez aguardar imóveis por volta de um minuto, para realizar o retrato de boa qualidade. Durante esse tempo, a luz natural que adentrava o estúdio fotográfico inscreveu a aparência daquilo que era focalizado pela câmara, na placa de vidro sensível, usada como negativo até fins do Império no Brasil. Nessa acepção, este retrato é um documento da realidade. Porém, uma realidade que fora completamente produzida, implicando numa minuciosa preparação para a foto: a escolha do foco, da pose, das roupas, do fundo etc. Essas escolhas produziram, por sua vez, significados que se associaram a tal existência passada e documentada. Daí o retrato-epígrafe documentar a relação entre a ama negra e a criança branca, como existente na São Paulo de 1870 (data em que foi tirado o retrato), além de representar e construir esse mesmo vínculo. ${ }^{3}$

A fotografia foi feita no atelier fotográfico de Militão Augusto de Azevedo ${ }^{4}$, chamado “Photographia Americana”; por essa fábrica de “realidades produzidas”, passaram milhares de

\footnotetext{
${ }^{2}$ Philippe Dubois. O ato fotográfico. Campinas, Papirus, 1994. Roland Barthes ao elaborar os conceitos de linguagem denotada e conotada, também trata desse paroxismo inerente à imagem fotográfica. Vide, sobretudo $O$ óbvio e o obtuso. Rio de Janeiro, Editora Nova Fronteira, 1990 e A câmara clara. Rio de Janeiro, Editora Nova Fronteira, 1984.

${ }^{3}$ Parte preliminar das reflexões que apresento a seguir podem ser encontradas em Rafaela de A. Deiab "A memória afetiva da escravidão” in: Revista de História da Biblioteca Nacional. Ano 1, nº 4, outubro de 2005. p. 36-40.

${ }^{4}$ Militão Augusto de Azevedo (18/06/1837 - 1905) nasceu no Rio de Janeiro, onde também faleceu. Os primeiros registros sobre ele se referem à sua carreira de ator, iniciada na então capital federal, por volta da década de 1860 . Mas, em 1862, o aspirante à carreira dramática já estava em São Paulo, pois são dessa data as primeiras vistas urbanas da cidade, que mais tarde serão utilizadas para compor o seu Álbum Comparativo. Suspeita-se que Militão já tivesse contatos com o ateliê Carneiro\&Smith no Rio de Janeiro, e que ocupasse o cargo de aprendiz no ateliê
} 
pessoas, cujos retratos ainda se preservam em seis álbuns, que funcionavam como catálogos dos negativos do fotógrafo. Esses catálogos eram guardados para o caso de os clientes requererem outras cópias de seus retratos no futuro ${ }^{5}$.

Essa indústria retratística, que se estabilizou no país na segunda metade do século XIX, trazia consigo certos padrões que se repetiam nas mais variadas fotografias; fosse em seus diferentes formatos (carte de visite, cabinet, vitoria, imperial ${ }^{6}$ ), nos paramentos que compunham o cenário no estúdio (fundo, móveis, tapetes) ou também nas diversas poses dos clientes.

No entanto, alguns desses esquemas que chegam junto com a técnica fotográfica supostamente neutra - são relidos no contexto local; e isso se faz evidente nas imagens das amas com suas crianças. A mãe, segurando a criança fortemente junto de seu rosto - apoiando-lhe a cabeça com as mãos - era um padrão internacionalmente reconhecido na época, uma forma de se garantir as fotografias com bebês. Em função da baixa sensibilidade do negativo, o tempo de exposição era muito longo (por volta de um minuto), sendo complicado manter os infantes imóveis. Aproximar as crianças junto ao rosto e segurá-las pelo dorso, visava à obtenção de uma postura estática, segura e garantida. Esse modelo de posição fica claro nessa imagem, [FIGURA 2] assim como as outras tantas preparações que tinham como objetivo um bom retrato.

Carneiro\&Gaspar, quando fez as primeiras fotos de São Paulo. Em 1868, o nome de Militão é publicado no jornal local, como sendo gerente da "Photographia Acadêmica", antigo ateliê Carneiro\&Smith. É justamente esse estabelecimento que ele compra, em 1875, rebatizando-o de "Photographia Americana".

${ }^{5}$ Esses mesmos álbuns estão disponíveis para consulta no Setor de Documentação do Museu Paulista/USP.

${ }^{6}$ Esses termos se referem a diferentes formatos de retratos. O carte de visite foi o mais popular entre eles, pois permitia a produção de doze imagens iguais (de 9,3 por $5,7 \mathrm{~cm}$, que eram coladas em cartões um pouco maiores) a partir de um mesmo "negativo", o que barateava muito o preço do retrato. Os cabinet eram fotos de 9,6 por 14,1 cm, que surgiram após 1860, e tornaram-se uma nova moda. Os Vitoria eram retratos de tamanho intermediário, que foram menos consumidos, ainda que fossem conhecido. Os de tipo imperial possuíam um formato ainda maior que o cabinet, sendo mais adequado para imagens destinadas a porta-retratos ou quadros. In: Militão: São Paulo - Álbum Comparativo da Cidade de São Paulo (1862-1887). Prefeitura do Município de São Paulo, 1981. p. 39 e Ricardo Mendes. CD-Room Militão Augusto de Azevedo e a cidade de São Paulo. Link "Fotografando com Militão". São Paulo, Museu Paulista -USP/Fundação Roberto Marinho, 1997. 


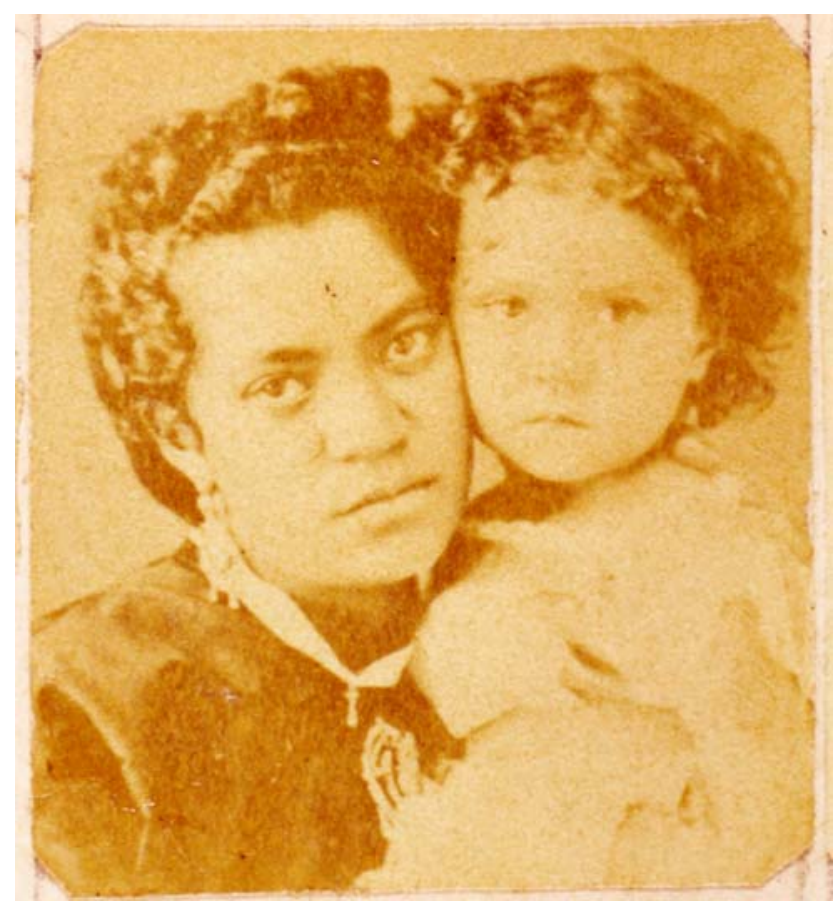

[FIGURA 2 -MILITÃO MAIO-1875]

O apuro na toillete materna é notável, condizente com o padrão das classes locais mais abastadas. O cabelo bem preso, a roupa de cor sóbria com colarinho alto, e o pescoço adornado com uma fita, da qual pende um pequeno crucifixo - aparentemente, uma jóia -, são detalhes importantes na composição. Outras jóias também estão presentes: o broche, logo mais abaixo, e os brincos compridos. Publicizar esse status mediante um meio técnico “insuspeito" como a fotografia, talvez fosse um dos objetivos do retrato. Já sobre a menina, dado o esmaecido da foto, não se pode dizer muitas coisas, além de destacar a roupinha clara com babadinhos e os cabelos soltos que ainda eram permitidos para mulheres dessa idade.

Esse modelo de pose, trazido da Europa juntamente com a fotografia e os fotógrafos, foi absorvido segundo a cultura local, de modo que, em nossa imagem-epígrafe, uma negra posa com a criança branca. Em poses internacionalmente indicadas para unir nas fotos mães e filhos, na São Paulo de meados do século XIX, surgem mães-pretas acompanhadas de seus filhos brancos, termos próprios de um contexto marcado pela escravidão doméstica, a qual promoveu múltiplas ligações entre senhores e escravos.

Agora, com um pouco mais de elementos, retorno àquele primeiro retrato [FIGURA 1] para uma análise mais detalhada. É notável como o fundo cinza destaca a ama e o garoto, uma vez que ambos são o objetivo - e foco - da imagem. A famosa pose está mais uma vez presente, e a ama tem seu rosto colado ao da criança, segura-a junto de si, apoiando-lhe a cabeça. A negra, 
responsável pela amamentação e pelos cuidados com a criança, era sua companhia "natural” nesses retratos; isso porque, estando mais habituados com elas, diminua-se o risco de que os bebês ficassem inquietos e, movendo-se, estragassem a nitidez do retrato.

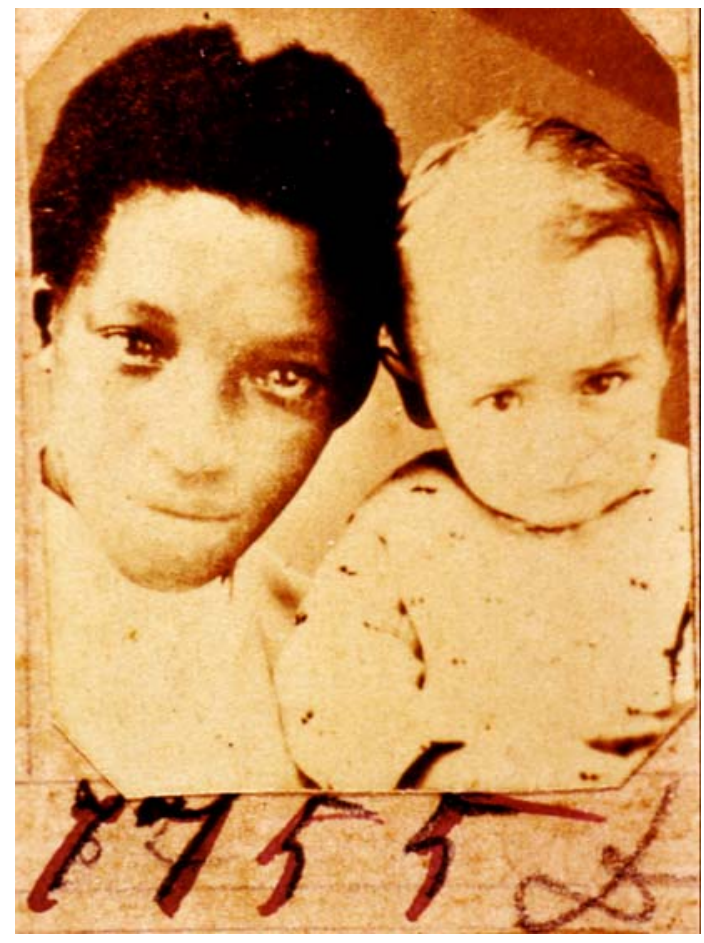

[FIGURA 3 - MILITÃO ABRIL 1876]

Neste outro retrato tirado em abril de 1876, [FIGURA 3] novamente o padrão se repete: uma ama negra segura a criança branca contra seu próprio corpo, de modo a mantê-la parada. A ama dessa imagem é, contudo, bem mais jovem que aquela do retrato anterior, e sua "produção" para a foto não está tão elaborada, possuindo menos detalhes. Os cabelos curtos estão arrumados numa tentativa de reparti-los (conforme se nota no alto da cabeça), não tão bem sucedida. Ela não usa brincos, está vestida apenas com uma roupa de gola alta e de cor clara; sinônimo, talvez, de limpeza. Nesse caso, ela não possui babados ou rendas. As amas mais velhas (como a do primeiro retrato), há mais tempo trabalhando dentro da casa, junto da família patriarcal, teriam mais chance de conquistar prestígio e pequenos favores dentro dela, e isso se refletiria no esmero de sua produção pessoal; seja para o retrato, seja para a ocasião dos passeios públicos com os seus senhores.

O bebê junto da ama mais jovem tampouco está irretocavelmente penteado; sua roupinha também é mais simples. Essa parcimônia de detalhes, que perpassa a negra e a criança, possivelmente significaria uma família mais "remediada” que aquela do retrato-epígrafe. O rosto 
do pequeno, num ensejo de choro, revela o incômodo que era para as crianças serem retratadas nesse estágio da tecnologia fotográfica. O fundo cinza repete-se, destacando ama e bebê, ambos num mesmo plano, conotando serem, igualmente, objeto do retrato, assim como a relação social tecida entre eles.

Nessas imagens, uma representação da relação entre a mãe-preta e o seu filho branco se faz presente: um vínculo muito próximo, de quase continuidade entre a negra e a criança branca; uma continuidade que caracterizaria qualquer relação maternal. Contudo, essa maternidade específica - entre a ama escrava e o filho do senhor - fora construída mediante a amamentação, cuidados e afetos desde a mais tenra infância. Portanto, a proximidade entre a negra e a criança branca, ainda que justificada em parte pelas limitações da técnica fotográfica, evidencia de modo explícito um vínculo afetivo fortemente estabelecido entre essas figuras.

Era mediante seu trabalho como escrava na casa senhorial que a ama tecia relações de intimidade com essa família, sobretudo com as crianças, tornando-se às vezes, sua "mãe de criação”. Essas escravas, deste modo inseridas nesse sistema, eram retratadas sempre muito bem arrumadas, junto dos herdeiros da família - de acordo com as possibilidades da família que encomendava o retrato - e com uma estética que em alguns pontos se aproximava à das senhoras brancas. Além do mais, os adornos dados ou emprestados à escrava distinguiam-na das demais criadas: seriam as cativas mais valorizadas.

A escravidão, relação marcada pelo arbítrio e exploração, proporcionara então um lugar genuíno para o estabelecimento de laços afetivos, mesmo que entre posições hierarquicamente tão distintas.

Nos anúncios de jornal, que tratam da compra e venda de escravos, por exemplo, a habilidade no trato com as crianças é um dos elementos dignos de destaque nas propagandas que os senhores fazem de suas escravas, mostrando que esse cuidado extremado era esperado e desejado pelas famílias:

“(Correio Paulistano, 22/02/1865) Mulatinha. Nesta typographia se dirá quem vende uma mulatinha com 7 para 8 annos de edade, com princípios de costura e muito geitosa para carregar creanças."

“(Correio Paulistano, 06/01/1865) Aluga-se uma creoula, sadia, muito própria para tratar de creanças, por ser muito carinhosa. Já sabe costuras, e engommar alguma cousa, sem vício nenhum: trata-se na rua do Braz defronte da igreja, armazém."7

\footnotetext{
${ }^{7}$ Grafia mantida como no original.
} 
Mas as escravas que trabalhariam dentro da casa da família branca, compartilhando de sua intimidade, e cuidando de seus filhos, além de serem “jeitosas” e “carinhosas” com as crianças, não poderiam ter “vícios”. Isto é, deveriam ser limpas e não apresentar hábitos pouco civilizados, como beber aguardente ou comer terra.

Gilberto Freyre, em seu ensaio Casa-Grande \& Senzala ${ }^{8}$, é um dos primeiros a dar bastante destaque aos laços sentimentais tecidos entre as mães-pretas e seus filhos brancos. As negras velhas, mães-pretas, amas-de-leite, sinhamas têm, na teoria do autor, um papel capital na formação da cultura mestiça brasileira. A ama negra promoveria essa mestiçagem por meio dos cuidados extremados com as crianças brancas, adocicando ou amolengando a cultura portuguesa, transmitida por ela aos pequenos. As histórias lusitanas que contavam nos serões eram adaptadas: tinham seus personagens mudados, e os cenários passavam a conter uma cor local, tornando-se mais compreensíveis para os infantes do que as distantes paisagens européias. Além disso, elas ainda davam outro ritmo às mesmas canções de ninar da tradição portuguesa que embalaram as gerações pregressas. Tinham cuidados com as crianças que iam desde a higiene do corpo, até o resguardo espiritual, por meio de simpatias, benzeduras e mezinhas; preparavam-lhes comidas especiais, ensinavam-lhes a rezar, além de nutri-los com seu próprio leite. ${ }^{9}$

Mas essa relação afetiva que tanto marca a infância brasileira só existiu mediante a separação desses dois pólos da relação (mãe-preta/filho branco) em status hierárquicos distintos: sinhôzinho e sua escrava. Sua, numa relação de posse promovida "por amor e direito de propriedade”. 10

Tal hierarquia e arbítrio próprios ao regime escravista se faziam ainda presentes, de outra maneira, quando se tratava das amas-de-leite ou mães-pretas. Para ter condições de aleitar um filho branco, era necessário que a escrava tivesse engravidado tendo, portanto, também um filho natural. Este último muitas vezes morria, era vendido, dado a criar mediante aluguel, ou levado para a Roda ${ }^{11}$. Quando permanecia junto de sua mãe, era na maioria das vezes preterido na

\footnotetext{
${ }^{8}$ Gilberto Freyre. Casa-Grande \& Senzala. Rio de Janeiro, Record, 1933/2001

${ }^{9}$ Idem. p. 382 passim.

${ }^{10}$ Luiz Felipe de Alencastro. "Epílogo” in: História da vida privada no Brasil vol.2. Op.cit. p. 439.

11 "[Casa dos Expostos] igualmente conhecida por Casa dos Enjeitados, Casa da Roda ou simplesmente 'roda', esta instituição foi criada em 1738 por Romão Mattos Duarte, com o objetivo caritativo-assistencial de recolher as crianças abandonadas. O nome de roda, pelo qual tornou-se mais conhecida, deve-se à assimilação da Instituição ao dispositivo onde eram depositadas as crianças. A roda era um cilindro de madeira que girava em torno de um eixo, com uma parte da superfície lateral aberta, por onde eram introduzidos os 'expostos'. Este dispositivo permitia que as crianças fossem entregues à Casa sem que o depositário e o recebedor pudessem ver-se reciprocamente. Jurandir Freire Costa. Ordem Médica e Norma Familiar. Rio de Janeiro, Edições Graal, 1979. p. 164. Além disso, caso as crianças sobrevivessem, sairiam libertas dessa Instituição. Para maiores detalhes sobre os diversos destinos que tinham os filhos das amas vide: Almir Chaiban El-Kareh. "Famílias adotivas, amas-de-leite e amas-secas e o
} 
alimentação, diante do filho branco do senhor. Esse mercado das amas-de-leite também aparece nos anúncios dos jornais:

“(Correio Paulistano, 05/02/1865) Escrava e filho. Quem quizer comprar uma mulata muito moça, sem vícios, sabendo cosinhar, lavar e engommar e estando com um filho de dous mezes e abundante leite, nesta typographia se dirá quem vende."

“(Correio Paulistano, 05/02/1865) Quem quizer uma ama de leite procure na rua de S. Bento, casa n. 47, por Antonio Francisco que com ele pode contractar."

Charles Pradez - um cidadão suíço - após viver vinte e cinco anos no Brasil, publicou (em 1872) o livro Nouvelles Études sur le Brésil, no qual comenta anúncios semelhantes a esses, publicados diariamente nos periódicos do Rio de Janeiro: "Uma coluna do Jornal do Commercio se enche todos os dias de anúncios de aluguel de amas-de-leite; para quem sabe do que se trata, cada linha representa um drama íntimo, a história do naufrágio de uma aflição santa ou indica uma cruel separação; cada anúncio significa lágrimas, luto e desespero! Apesar disso, o interesse pesa sobre essas coisas e outras, cada ama corresponde de 120 a 150 francos por mês. Tirar o filho de sua mãe! Não é atroz? Não é revoltante? Pois é: fala-se da emancipação diante de algumas pessoas mais ou menos interessadas em manter a ordem de coisas atual e elas responderão se é utópico, visionário, que os operários europeus são muito mais infelizes que os negros etc. etc.”12 A figura da ama-de-leite, portanto, não implicava apenas numa exaltação da relação afetiva com o filho branco do senhor; mas também, em algumas ocasiões, num alerta para a crueldade a que ela era submetida ao ser apartada de seu filho natural.

Médicos ligados à Santa Casa de Misericórdia carioca também testemunharam a separação da escrava de seu filho natural para que se tornasse ama-de-leite. Dr. Vieira considerava essa prática abusiva: “é necessário reprimir o abuso dos senhores de escravos, que mandam lançar na roda ou abandonam os ingênuos com o fim de alugarem as mães ou obterem delas maior soma de trabalho” ${ }^{13}$ Por sua vez, Dr. Neves reafirmava essa condenação numa fala pormenorizada sobre a escrava separada de seu filho natural: "Há entre os senhores das escravas um método horrível e que influi extraordinariamente sobre a moral das escravas, tornando assim o leite nocivo às crianças, isto é, mandar pôr na roda os filhos destas, para assim recuperarem melhor seu aluguel. Observei com grande mágoa muitos destes fatos, quando fui interno de uma

comércio de leite e de carinho na corte do Rio de Janeiro" in: Gênero: Núcleo Transdisciplinar de Estudos de Gênero - NUTEG. Niterói, EdUFF, 2004. Vol. 4, n. 2.

${ }^{12}$ Charles Pradez apud Miriam Moreira Leite. Retratos de Família. São Paulo, Edusp, 2000. p. 69.

${ }^{13}$ Dr. Vieira apud Jurandir Freire Costa. Op. cit. p.167. 
das maternidades da Corte. Adormecida a pobre parturiente, quando ela procurava pelo sono recuperar as forças exaustas no doloroso trabalho de parto, tiravam-lhe o seu inocente filhinho e mandavam colocá-lo na roda; mais tarde, quando a desgraçada acordava e procurava com ansiedade o fruto de suas entranhas, é que sabia que ele havia sido levado para a roda, desfaziase em lágrimas e mergulhava-se em uma grande tristeza. Este fato, que à primeira vista parece pouco importante, influi de tal modo sobre a moral da escrava, que a torna inapta a aleitar outra criança”. 14

Na fala desses dois médicos já é perceptível uma maior preocupação com as escravas, sobretudo com sua salubridade (uma mescla de condições físicas e morais), e a qualidade de seu leite. Tal postura estaria relacionada, por sua vez, a uma onda de epidemias que, a partir de 1850, atingiu a cidade do Rio de Janeiro, contaminando sobretudo sua população mais vulnerável: as classes menos abastadas, compostas por escravos urbanos, libertos, e brancos pobres, que se concentravam nos abundantes e temidos cortiços. ${ }^{15}$ Febre amarela, cólera, varíola, escarlatina, tuberculose, malária e sífilis ceifaram a vida de milhares de pessoas. ${ }^{16}$ Diante desse quadro alarmante de doenças, os moradores dos cortiços, entre os quais se encontravam as criadas domésticas, passaram progressivamente a ser identificados com as enfermidades, tornando-se um “foco de contágio ambulante”, temido pela casa patriarcal. “Agravavam-se as ansiedades quando se identificavam os pobres em geral, e as criadas em particular, como portadoras de contágio. Tal visão não se configurou de uma só vez, mas nas últimas décadas do século [XIX] a velha imagem do cortiço como um ambiente prejudicial desapareceu, sendo substituída pela imagem dos moradores do cortiço contaminados e contaminando incessantemente toda a população da cidade (...)". ${ }^{17}$

As criadas domésticas, especialmente as amas-de-leite, tornam-se liminares nesse contexto. Perigosas, elas trariam as doenças transmitidas pelos habitantes dos cortiços para a intimidade da família branca. "Porque nutria o recém-nascido desde os primeiros e precários momentos, a ama-de-leite tornou-se para os patrões a mais terrível e alarmante transmissora de doenças. A partir da metade do século, aparecem imagens divergentes da ama-de-leite. Ela não era mais a encarnação do alimento e dos cuidados afetuosos; tornou-se também um espectro da

\footnotetext{
${ }^{14}$ Dr. Neves apud Jurandir Freire Costa. Op. cit. p.167.

15 Em 1867, a cidade contava com 502 cortiços, mas esse número foi aumentando num crescente impressionante: dois anos depois já são 642; e em 1888 chegam à marca dos 1331. Sandra Lauderdale Graham. Proteção e Obediência. São Paulo, Companhia das Letras, 1992. p. 140.

${ }^{16}$ Para maiores informações sobre os anos das diferentes epidemias e seus respectivos números de morte consultar: Sandra Lauderdale Graham. Op. cit. p. 130 e 131.

${ }^{17}$ Idem. p. 135.
} 
doença medonha. Com o leite de seu corpo podia infectar o inocente com tuberculose, ou até mesmo sífilis. As moléstias que antes os patrões consideravam seu dever cuidar, como símbolo mais dramático dos cuidados devidos aos dependentes, vieram a ser consideradas importações transpostas pelas criadas, sobretudo pelas amas-de-leite, para dentro das casas outrora protegidas."18

É com esse discurso pautado pelo higienismo, e pelo temor da contaminação promovida pelas amas, nomeadamente as negras, que Gilberto Freyre dialoga em Casa-Grande \& Senzala. Ele argumenta que muitas vezes as amas foram veículo de contaminação, mas que a recíproca também era comum: elas acabaram igualmente contaminadas pelos sinhôzinhos. ${ }^{19}$ É desse contraponto representacional - entre amas promotoras de contágio e amas promotoras de mestiçagem cultural - que surge a reincidente preocupação do ensaísta pernambucano em mostrar que as mães-pretas não foram apenas inoculadoras de doenças na casa-grande mas, principalmente, inoculadoras de cultura: “mas o ponto que pretendemos destacar não é o das fundas afeições, quase de mãe e filho, que no tempo da escravidão se formavam entre escravas amas-de-leite e nhonhôs brancos; mas retificar a idéia de que através da ama-de-leite o menino da casa-grande só fizesse receber da senzala influências ruins; absorvendo com o primeiro alimento os germes de todas as doenças e superstições africanas. Os germes de doenças, recebeuos muitas vezes; e outras os transmitiu; mas recebeu também nos afagos da mucama a revelação de uma bondade porventura maior que a dos brancos; de uma ternura como não a conhecem igual os europeus; o contágio de um misticismo quente, voluptuoso, de que se tem enriquecido a sensibilidade, a imaginação, a religiosidade dos brasileiros”. ${ }^{20}$

Mas aquela mudança valorativa diante da amamentação por parte das cativas, em especial pelas amas negras, num contexto já marcado pela iminência da abolição, começa também a ficar patente, em princípios dos 1880, nos novos termos que surgem nos anúncios de jornais: "amas brancas”, "preferência por brancas ou estrangeiras”, "preferência por captivas”, "ama se oferece” e "professoras estrangeiras". Tais são as categorias que começam a pulular nesse tempo de transição.

“(A Província de São Paulo, 11/01/1883) Ama de leite. Precisa-se de uma que seja sadia, preferindo-se a côr branca. Para tratar rua da Imperatriz n.2, 20 andar."

\footnotetext{
${ }^{18}$ Idem. p. 137.

${ }^{19}$ Gilberto Freyre. Op. cit. p. 373.

${ }^{20}$ Idem. p. 408 e 409.
} 
“(A Província de São Paulo, 03/03/1883) Ama. Precisa-se de uma preferindo estrangeira."

“(A Província de São Paulo, 04/10/1880) Criada. Precisa-se de uma para carregar criança. Prefere-se branca e estrangeira. Tratar na r. Direita n. 8."

“(A Província de São Paulo, 13/09/1880) Ama de leite. Uma boa ama de leite se offerece para receber e amamentar uma criança em sua casa, rua 21 de maio n.28, no Chá."

“(A Província de São Paulo, 14/09/1880) Ama de leite. Precisa-se de uma que seja sadia: prefere-se captiva, sem filho. Para tratar na rua de Santo Amaro em frente ao matadouro."

“(A Província de São Paulo, 22/09/1883) professora. Uma senhora estrangeira habilitada a lecionar allemão, francez, inglez, desenho deseja encontrar uma família n'esta cidade, ou n'uma fazenda da província como dama de companhia."

Esses novos termos sinalizam grandes modificações. Eles levam a significados mais profundos presentes nessa alteração de referências culturais, decorrente do avanço do pensamento médico higienista, aliado ao processo de declínio do sistema escravista e o início mais sistemático da imigração. Uma aproximação mais detalhada desse período pode revelar nexos nessa mudança de "preferências".

Sintomático desses novos tempos, pontuado por idéias inovadoras relacionadas à amamentação e à nutrição infantil, é o anúncio de um produto bem “moderno”: a farinha láctea. “A escassez da ama sadia e baba, o seu preço elevado tem tornado a introdução da farinha láctea Nestlé um verdadeiro benefício para o Brasil. Hoje uma mãe pode ter a satisfação de criar seu filho com o leite se tiver pouco, sem risco de enfraquecer nem sofrer na sua saúde (...)”. ${ }^{21}$ Nesse caso, fica claro como a publicidade do produto estrangeiro tem de dialogar com os valores e o imaginário local. Nessa medida, evidencia as benesses desse alimento para toda a nação, que poderá finalmente substituir as “antigas” amas - que começavam a ficar mais caras, e raramente sadias, com a aproximação da abolição.

Os argumentos econômico e médico não por acaso aparecem lado a lado e conjugados: nesse momento de "alta” do discurso científico (considerado racional e civilizado), a medicina será evocada para, de maneira neutra, justificar situações hierárquicas há muito consolidadas. “Antes peça indispensável, o escravo tornava-se agora número indesejável. Sua existência, até então sinal de conforto, convertia-se em ameaça de doença. Essa versão médico-política do 
escravo coincidia com o movimento econômico que tendia a suprimi-lo da cena social. Com efeito, o hábito de ter escravos no serviço doméstico foi sendo dificultado pelas mudanças econômicas e culturais por que passava o Brasil. Desde a extinção do tráfico negreiro os escravos tornaram-se mais caros e mais difíceis de obter. A família adaptava-se mal a esta situação. Habituada, desde muito, a depender do trabalho servil mostrava sua inépcia em acompanhar a evolução social. A higiene, apontando o escravo como um mal, reforçava a ordem econômica, ensinando a família a prescindir dele. Transformando a necessidade em virtude, os médicos tornavam o inevitável, desejado.”22

O anúncio da farinha láctea revela, também, o imaginário existente em torno da amamentação materna, pautada pelo receio de enfraquecimento e de perda da saúde. Porém, agora a fragilidade do bem-estar materno (remediada por produtos como a farinha láctea) parece preferível perante os “novos riscos” da amamentação feita por escravas. Houve nos jornais e nas escolas de medicina acaloradas discussões sobre os malefícios ou benefícios desse tipo de amamentação: “às famílias abastadas e educadas os médicos ministravam conselhos detalhados sobre os atributos ideais de uma ama-de-leite. Embora dissessem que as 'amas brancas serião a todos os respeitos preferiveis’, estas eram menos adequadas no calor dos trópicos que as pretas, cuja 'saude prospera nas regiões calidas'. Assim, um médico insistia em que se escolhesse uma 'preta [...] moça, forte e robusta', enquanto outro achava as mulatas melhores que as brancas; sobretudo as louras.” ${ }^{23}$ Amas negras, mulatas, brancas etc., esse impasse de recomendações entre os médicos revela, muitas vezes, uma tácita associação da medicina higiênica com as "teorias racistas” tão em voga nos meados do XIX brasileiro. ${ }^{24}$ Mas essa crise no "aleitamento por amas mercenárias” - tal é o termo cunhado em 1873, por José Pereira Rego, Barão do Lavradio, e presidente da Junta Central de Higiene Pública -, concomitante ao fantasma da contaminação da família branca, pressionava cada vez mais para uma redefinição dos papéis associados à senhora branca.

${ }^{21}$ Correio Paulistano 4 de abril de 1876. Apud Lilia Moritz Schwarcz. Retrato em branco e negro. São Paulo, Companhia das Letras, 1987. p.59.

${ }^{22}$ Jurandir Freire Costa. Op. cit. p. 124 e 125.

${ }^{23}$ Sandra Lauderdale Graham. Op. cit. p. 138. Esse debate acalorado em torno da alimentação infantil e das vantagens e desvantagens do aleitamento por amas se faz nas teses da Faculdade de Medicina do Rio de Janeiro, nos guias médicos adotados pelas famílias e, ainda, nos periódicos. Dr. João Baptista Imbert e Dr. Moncorvo de Figueiredo, assim como seu filho, são figuras de destaque nessas discussões. Para um aprofundamento nesse debate vide: Sandra Lauderdale Graham. Op. cit., principalmente capítulo 5 "Contágio e Controle”.

${ }^{24}$ Para um estudo sobre essas teorias, seus diagnósticos da realidade brasileira e marcas profundas deixadas no pensamento social nacional vide: Lilia Moritz Schwarcz. O espetáculo das raças. São Paulo, Companhia das Letras, 1993/2000. 
A mãe branca, enquanto figura mais “elevada”, poderia agora transmitir no leite esta qualidade a seu filho. "Na Europa [e no Brasil] há toda uma discussão sobre as vantagens do leite materno, a fim de garantir melhores cuidados ao bebê e supostamente, transmitir-lhe, pelo leite, as qualidades naturais de sua mãe. Pouco a pouco o costume das amas-de-leite de aluguel declina, e o médico baseado numa nova especialidade - a puericultura -, intervém cada vez mais no cuidado dos bebês, em detrimento de práticas e da autoridade materna”. ${ }^{25}$ A "recriminação" do aleitamento por amas implicou, portanto, numa paulatina mudança das funções da senhora branca dentro da família e no interior da sociedade mais abrangente. Revelador desse processo foi o lançamento, em 1879, do jornal A Mãi de Família: “almejando influenciar as senhoras em que cumprissem adequadamente seu papel materno, a revista defendia que as mulheres, nascidas para ser mães, deveriam empenhar-se tanto em sua vocação que fizessem qualquer sacrifício necessário”. ${ }^{26}$

Contudo, hábitos muito arraigados, cultivados desde os idos do século XVI, não se abatem rapidamente pelas novas teorias: uma mudança nem tão radical seria a contratação de amas brancas; melhor ainda se estrangeiras.

As novas imigrantes brancas pobres usufruiriam do "nicho de mercado” já aberto pelas negras escravas, agora entendidas como insalubres. Nessa medida, elas, alfabetizadas, se oferecem nos jornais para amamentar filhos alheios na própria casa. Luiz Felipe de Alencastro analisa esse novo quadro social por meio da mudança da função sintática da palavra "se”: “uma oferta de senhora (...) que inverte o pronome pessoal se, mudando a partícula apassivadora do verbo pronominal em objeto direto, ativo: uma mucama é posta a alugar-se pelo seu proprietário, a senhora livre se aluga ela própria”. ${ }^{27}$

Há ainda aqueles senhores e senhoras que, impregnados da lógica da escravidão, são mais resistentes a esse processo de "modernização", que os retiraria da posição central de poder exercido mediante a concessão de favores e punições, dosados esses pelo uso da força física. Eles preferem as “captivas”, que submetidas à supervisão do senhor e "obedientes”, representavam uma ameaça menor à ordem escravista exemplificada pelo poder senhorial.

\footnotetext{
${ }^{25}$ Luiz Felipe de Alencastro. "Vida privada e ordem privada no Império” in: História da vida provada no Brasil volume 2. Op.cit. p.64 e 65. Almir Chaiban El-Kareh argumenta que a prática de "senhoras", termo que indica serem livres ou libertas, receberem crianças para amamentarem ou criarem em suas casas era disseminado desde fins de 1850 na Corte. Almir Chaiban El-Kareh. Op. cit. p. 18 e 19.

${ }^{26}$ Sandra Lauderdale Graham. Op. cit. p. 144. Esse jornal feminino durou até 1888. Para um estudo mais sistemático de seu projeto editorial vide: Sonia Maria Giacomini. "A conversão da mulher em mãe: uma leitura do 'A Mãi de Família” ” in: Revista Brasileira de Estudos de População. Campinas, vol. 2 n. 2, 1985. p. 71-98.

${ }^{27}$ Idem. p. 64.
} 
Ainda que os processos sociais não sejam progressivos e unívocos, o fato é que o aleitamento por amas negras foi declinando. Durante o século XIX, é de se imaginar que as teorias higienistas e racistas, discutidas e subsidiadas pelas instituições de saber, se espalhavam por toda a sociedade influenciando, inclusive, as representações das serventes domésticas, entre elas a ama-de-leite. “O que se pode dizer é que (...) essa 'visão racial’ da nação partiu dos estabelecimentos científicos, mas esteve presente sobretudo no domínio das relações pessoais e das vivências cotidianas justificando hierarquias sociais nomeadas em base a critérios biológicos (nesse movimento que partia das instituições de saber para alcançar o senso comum e viceversa)". ${ }^{28}$

Em um mundo de tantas ilustrações, ciências e teorias, melhor opção do que a negra que amolece o português introduzindo outra cadência, são as professoras estrangeiras que preparam meninos para um mundo mais especializado, técnico e cosmopolita. “Os brasileiros, levados a competir em prestígio e enobrecimento de modos com os europeus, começaram a dispensar seus negros e a contratar preceptoras e governantas estrangeiras encarregadas de civilizarem seus modos, educarem seus filhos, europeizarem suas casas.”29 Sintomática dessa preferência, recentemente forjada, é a descrição da criada doméstica perfeita, feita pela romancista Júlia Lopes de Almeida, em seu Livro das Noivas, de 1896: “uma rapariga suíça com 'faces côr de nata e cabello côr de milho maduro'”, ${ }^{30}$

Nessa medida, nos momentos de desmontagem da escravidão, o elemento negro torna-se um sinal do passado retrógrado que não convém mais mostrar nos retratos com os bebês. Interessante notar que neste período, com uma maior penetração das teorias racistas, o antigo negro escravo passa a ser representado pelas elites e jornais como africano, termo que possuía nesse instante correlação quase direta com a idéia de barbárie. “A África era, portanto, um tema

\footnotetext{
${ }^{28}$ Lilia Moritz Schwarcz. Op. cit. 1993/2000. p. 247. Segundo a autora, diferentes vertentes de teorias científicas chegaram ao Brasil em meados de 1870; e foram reelaboradas de modo criativo ao serem consumidas pelos intelectuais nacionais. Desse modo, evolucionismo social, darwinismo social, determinismos geográfico e racial, além de uma antropologia criminal, se mesclaram nas diferentes instituições de ensino criadas durante o Império. Os museus etnográficos enfatizavam os argumentos evolucionistas, hierarquizando animais e gentes, e atestavam o exotismo deste país de formação racial mista. Nos Institutos Históricos e Geográficos responsáveis pela construção da história da recente nação, o evolucionismo era misturado ao darwinismo social que juntos explicavam o predomínio do branco e sua posição na hierarquia social, além da "natural tendência para o branqueamento" da população. Nas escolas de Direito, diagnosticava-se uma lenta evolução da nação, prejudicada pela "anarquia de raças", que era associada a uma tendência para a criminalidade. Assim, nessa instituição, evolucionismo, determinismo racial e antropologia criminal também se misturavam. Nas faculdades de Medicina, determinismo racial e teorias eugênicas aparecem com maior destaque para cuidar do problema das raças. Supostamente, só com a eliminação ou segregação dos negros e mestiços haveria chances para o avanço da nação. São essas combinações, descritas em linhas muito gerais, que passam a informar as relações pessoais deste contexto.

${ }^{29}$ Jurandir Freire Costa. Op. cit. p.125.

${ }^{30}$ Sandra Lauderdale Graham. Op. cit. p. 35.
} 
importante e recorrente [nos jornais do fim do XIX em São Paulo](...) porque informava sobre a própria população negra aqui residente. No caso desses artigos, a intenção parecia clara e as oposições presentes, bastante fixas. Ou seja, enquanto a África ia sendo interpretada como 'berço do barbarismo, da violência, da superstição e da magia’, a Europa representava a civilização, o progresso e a paz.”31

Daí, progressivamente, as amas deixarem de ser foco e objetivo do retrato, tal qual quando estavam posicionadas num primeiro plano junto com os bebês brancos. Tornam-se, então, segundo plano, ficam desfocadas, ou mesmo, são cortadas das fotos.

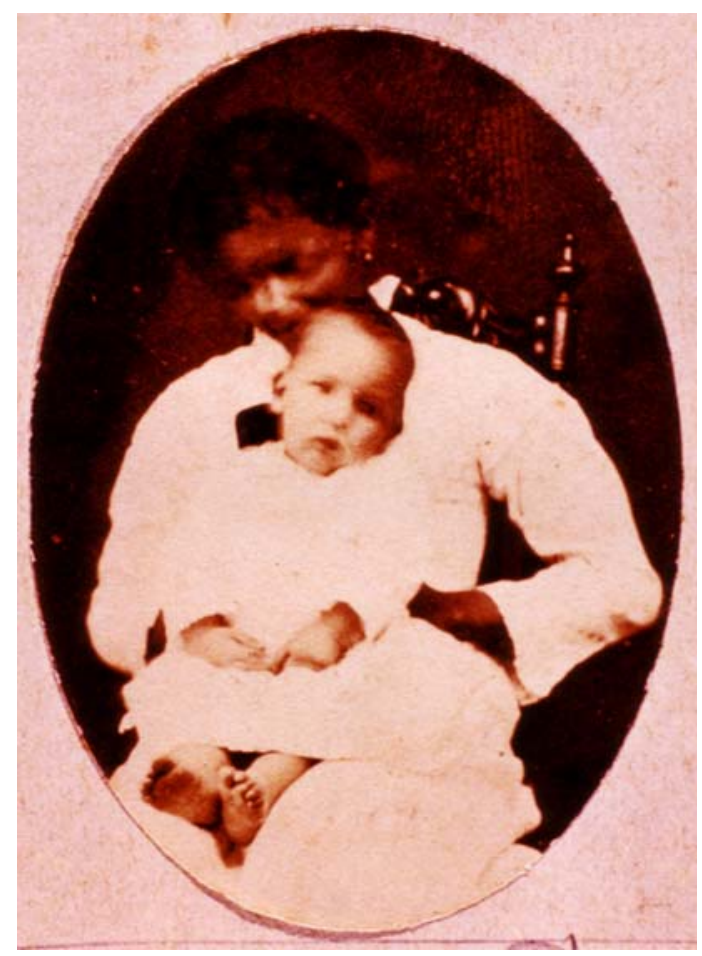

[FIGURA 4 - MILITÃO MARÇO 1883]

Neste outro retrato feito, também por Militão Augusto de Azevedo, em março de 1883, o objetivo talvez fosse apresentar tanto a imagem da ama negra quanto da criança branca; uma vez que ambos se apresentam de corpo inteiro. Contudo, há uma hierarquia que se revela nos diferentes planos. No primeiro plano da foto, está o bebê, posando acomodado no colo de sua mãe-preta, sentada numa cadeira cujo encosto é ricamente trabalhado. Ela, por trás da criança, serve de sustentação e moldura para que o pequeno apareça da melhor maneira possível no retrato. Apóia em toda a extensão de seu tronco e pernas “o sinhozinho”, segura-o pela cintura, de modo a mantê-lo estático durante a sensibilização do negativo, recostando ainda sua cabecinha

\footnotetext{
${ }^{31}$ Lilia Moritz Schwarcz, Op.cit. 1987. p. 117
} 
em seu colo, amparando-a com seu queixo. O bebê apresenta-se numa posição milimetricamente arrumada pelo fotógrafo; notável, sobretudo, pelas perninhas paralelas e esticadas para a frente, que estavam em simetria com as mãozinhas juntas colocadas sobre as pequeninas coxas. A ama, trajando um vestido claro de gola alta, enfeitado por um laço preto na pala, com a cabeça um pouco inclinada para frente, tem parte de seu rosto recoberto pelo nenê branco. Além disso, provavelmente se movera durante a produção do retrato, de modo que a imagem da face está completamente borrada, ficando registrado apenas o reflexo da luz na região do nariz e o brilho do pequeno brinco que usa na orelha.

Ainda que a ama negra fosse parte relevante da imagem, nesse retrato, sua função instrumental de apoio para o menino branco fica mais evidente. Esse também é o caso deste outro retrato, tirado em outubro de 1877.

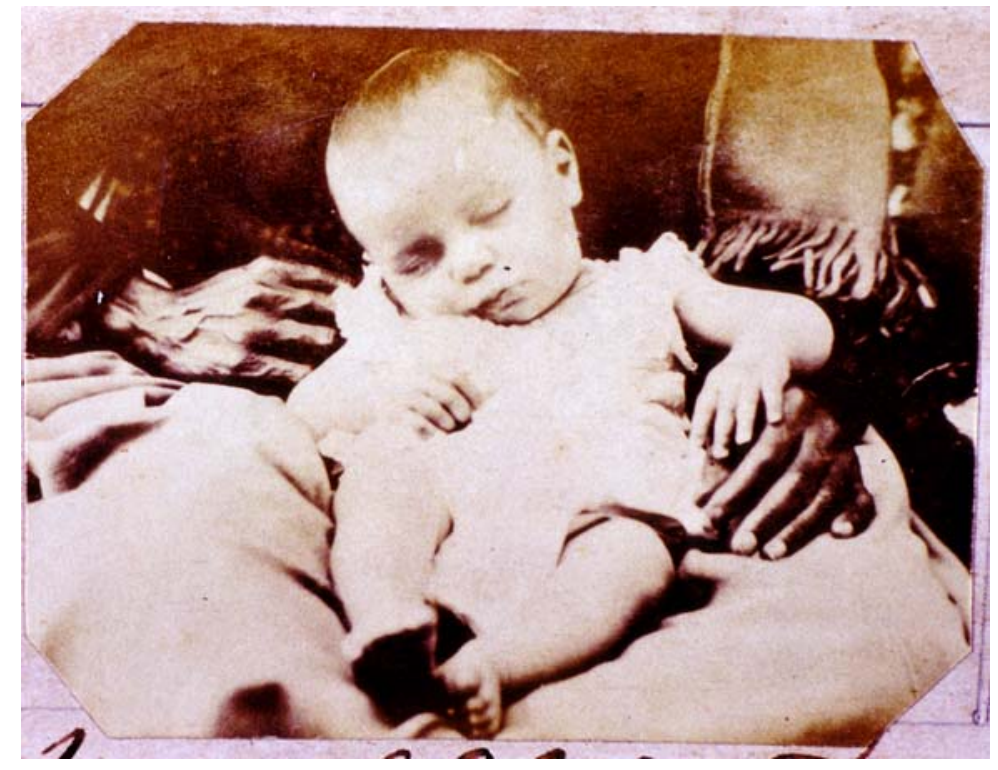

[FIGURA 5 - MILITÃO OUTUBRO 1877]

Aqui, como o retrato está recortado no original, não há como saber se a negra estava de corpo inteiro na imagem. Contudo, esse recorte feito pelo próprio fotógrafo é, em si mesmo, significativo. Ele revela que o cliente encomendara uma fotografia da criança, de modo que ela permanece na seleção da imagem colada no álbum que servia de índice dos negativos. Assim, caso o cliente retornasse querendo outras cópias daquele mesmo clichê, ele procuraria o bebê branco que constituía, possivelmente, o objetivo do retrato.

O bebê branco, de roupa também clara e com babadinhos, está deitado e aconchegado no colo de uma negra, recoberto este por um manto (talvez por sugestão do fotógrafo). Do corpo da ama só vemos as mãos, com veias salteadas e vincos que revelam sua idade já avançada. Sua mão 
esquerda está servindo de apoio para o ombro da criança; já a direita, encontra-se pousada logo abaixo dos pequeninos braço e mão do nenê. ${ }^{32}$ A cabeça dele está recostada na barriga da ama; tal posição deveria ser cômoda a ponto de a criança dormir completamente entregue em seu colo. Parafraseando o comentário de Luiz Felipe de Alencastro, para outra fotografia de mãe-preta com filho branco $^{33}$, o olhar do menino se fecha no devaneio dos sonhos e das coisas postas no seu devido lugar: ela, ao fundo, e servindo, aconchegantemente, de berço ao seu sinhozinho branco, que lhe retribui o gesto, dormindo rendido sobre seu corpo.

Nessa próxima imagem, igualmente realizada em São Paulo, no ateliê de Militão, não restam dúvidas sobre quem é o foco central do retrato: o bebê branco. Da ama negra temos apenas os rastros deixados por suas mãos, a amparar o objeto de desejo daquele que encomendara a fotografia. A pose da ama e da criança é muito semelhante àquela presente na figura 4: há uma negra sentada que acomoda em seu colo o menino branco. Ela firma a postura do pequeno segurando-lhe logo abaixo dos ombros, ou pela cintura. Naquela foto a mãe-preta estava em segundo plano, mas de corpo inteiro, ainda que o rosto estivesse embaçado ou desfocado.

\footnotetext{
${ }^{32}$ Roland Barthes em A Câmara Clara criou uma metodologia própria para discorrer sobre as fotografias, chegando aos conceitos distintos e não excludentes: studium e punctum. O primeiro se refere a um interesse pelas imagens que visa uma compreensão, um "investimento geral ardoroso". O segundo conceito "parte da cena como uma flecha, e vem me transpassar. Em latim existe uma palavra para designar uma ferida, essa picada, essa marca feita por instrumento pontudo; essa palavra me serviria em especial medida em que remete também à idéia de pontuação e em que as fotos de que falo são, de fato, pontuadas, às vezes até mesmo mosqueadas, com esses pontos sensíveis; essas marcas, essas feridas são precisamente pontos.” (A Câmara Clara Op.cit. p. 45 e 46 ) Esse pequenino detalhe - a frágil mãozinha branca sobre a mão negra adulta - teve em mim um efeito pungente tal qual um punctum. Isso porque ela remete a todo um universo de imagens (largamente explorado) ligado à maternidade e a contatos interraciais.

${ }^{33}$ Trata-se do retrato feito no estúdio fotográfico de Villela, no Recife, trazendo a ama negra Mônica e o menino branco Arthur Gomes Leal. A imagem está na capa do volume e é analisada por Luiz Felipe Alencastro, no
} 


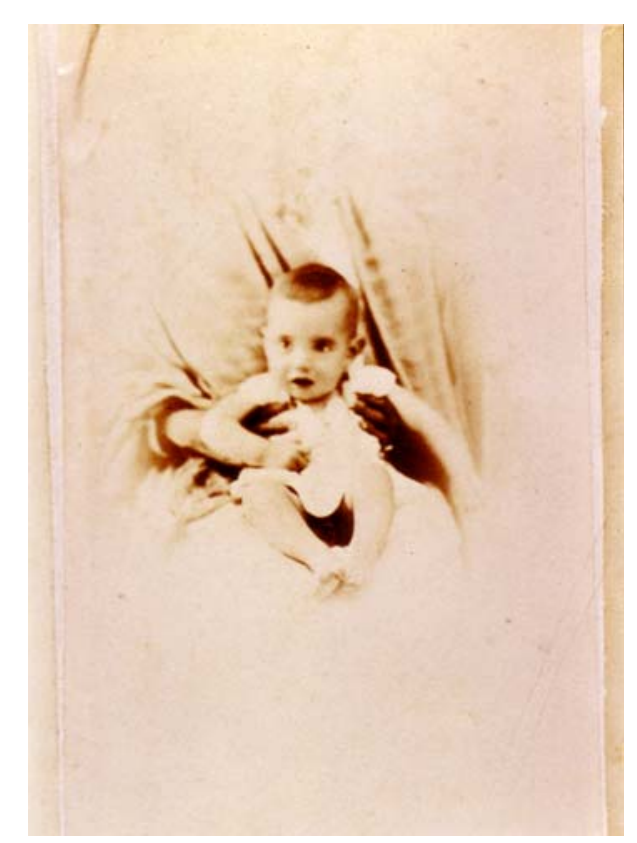

[FIGURA 6 - MILITÃO ABRIL 1879]

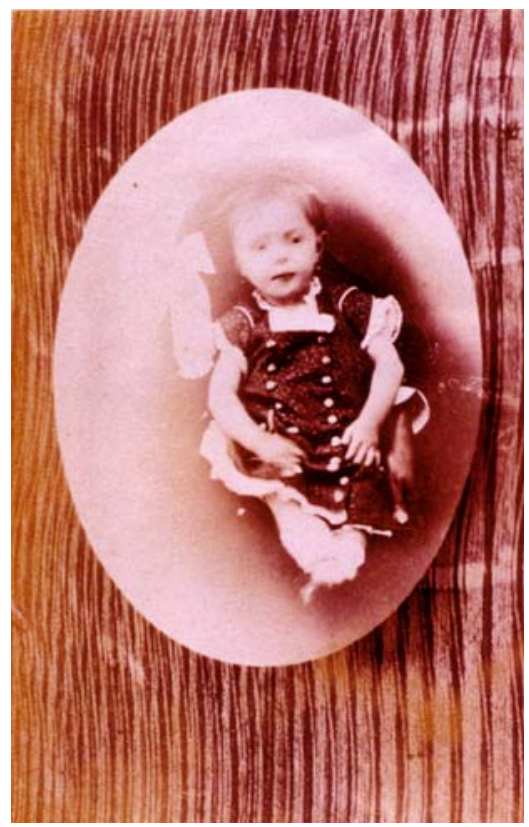

[FIGURA 7 - MILITÃO MAIO 1880]

Aqui [FIGURA 6] não há sequer a cabeça da ama, e tampouco os limites de seu próprio corpo que, progressivamente, mesclam-se com o campo claro fora da moldura oval. Vê-se apenas um tecido branco, disposto sobre o colo da ama, embaixo do bebê. A negra, preparando-se para o retrato, no qual serviria apenas de apoio para o foco da imagem, usava um vestido claro e sobre as costas um provável xale ou pano da costa.

No retrato seguinte [FIGURA 7], já não resta dúvida de que a menina branca era seu único objeto. A fotografia, que recebeu igualmente uma moldura oval, só permite notar a presença da ama negra, a sustentar em seu colo a criança branca, por conta de seu punho, que ladeia o corpo da pequena. Essa última traz um belo vestido de tecido escuro de bolinhas, com muitos botões de enfeite, além dos babadinhos em toda sua extremidade. A menina apresenta também um par de pequenos brincos nas orelhas. A ama, ainda que em segundo plano, desfocada e cortada do retrato, estava bem vestida. Trajava um vestido escuro, com um laço e a barra da manga claros. Mesmo estando bem “produzidas”, e numa pose que supria as necessidades de apoio para a execução de um bom retrato, a fotografia não teve resultados satisfatórios. O

“Epílogo” in: História da vida privada no Brasil vol.2. Op.cit. p. 439. A frase original é: “O olhar do menino voa no devaneio da inocência e das coisas postas em seu devido lugar”. 
fotógrafo, ao tentar excluir a ama da foto, clareando a porção em que seu corpo e rosto apareciam, acabou por embaçar o rosto da garotinha, alvo da encomenda do retrato.

A convivência entre amas negras e crianças brancas, promotora de uma reciprocidade afetiva, contribuía para que os bebês saíssem bem nos retratos. Isso porque já habituados à sua companhia, os pequenos ficavam mais tranqüilos para enfrentar o longo minuto estático. As escravas, dirigidas pelo fotógrafo-artista, auxiliavam na execução de uma boa fotografia, ao apoiarem contra seu próprio corpo as crianças inquietas. No entanto, algumas mudanças vão ficando evidentes. Nos idos de 1870, essa pose ideal para execução das fotos, trazia a ama negra e a criança branca no mesmo plano, de rostos colados e ambos bem focados. Com a aproximação da década de 1880, as amas, ainda companhia dileta das crianças, continuam a ajudar o fotógrafo em seu trabalho; contudo, nessas novas composições, elas estão em segundo plano, desfocadas ou cortadas do retrato. Tornam-se um mero apoio, ainda que absolutamente aconchegante, para os bebês brancos: única finalidade da fotografia. Restam, então, crescentemente apenas rastros de sua presença - uma mão, um punho, até serem completamente banidas das imagens; ajudadas pela técnica (que diminuíra consideravelmente o tempo de exposição para a tomada do retrato), permitindo que as crianças fossem fotografadas sozinhas. Nessa fotografia de 1880, a bebê está sozinha, ao centro da imagem, sem ninguém para lhe amparar. Nota-se apenas um repuxado de tecido em torno.

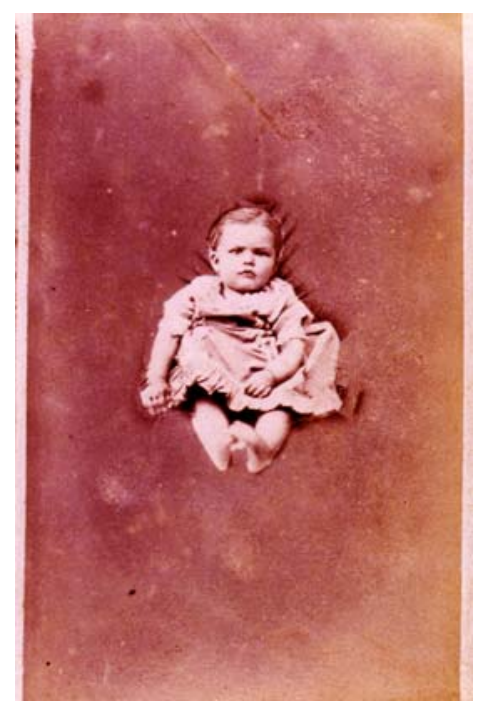

[FIGURA 8 - MILITÃO MARÇO 1880]

Talvez, as mães-pretas tenham sido paulatinamente substituídas a priori pela ama branca e depois pelas governantas ou tutoras as quais, pela origem “caucásica”34, deixam então de ser identificáveis pelos retratos. Definitivamente, os processos culturais têm uma outra

\footnotetext{
${ }^{34}$ Termo usado por Gilberto Freyre para se referir aos estrangeiros de ascendência européia.
} 
temporalidade peculiar, re-inventando e re-interpretando os artífices que ocupam um quase mesmo lugar nos sistemas de relações, há tanto tempo sedimentado.

Nesse sentido, por meio dessa série de fotografias, vislumbrei um movimento nas representações, sobretudo da relação entre a ama negra e a criança branca: em princípio, de 1860 até por volta de 1870, as escravas eram relativamente valorizadas e naturalizadas pela sociedade. Ao serem expostas, junto aos bebês de seus senhores, tornavam evidente, pelo apuro de sua aparência, o status da casa em que eram propriedade. Porém, no final do período escravista, já não era mais considerado adequado associar os sinhozinhos com as suas negras, posto que a escravidão passava a ser sinônimo de uma instituição perigosa, retrógrada, que não se encaixava nas novas ambições de um Brasil “civilizado”, “moderno” e "branco”. "Logo, nos anos 1880, tudo que lembrasse a escravidão deveria ser devidamente criticado por essa 'elite ilustrada' que, ao mesmo tempo que publicava anúncios de fuga de escravos, condenava veementemente seus proprietários. (...) Em todas as notícias o tema central era comum, ou seja, a condenação dessa instituição considerada pelo jornal como decadente e pouco digna do ‘grau de civilização' que havíamos alcançado.”35

Assim, a posição das elites - sempre desejosas de forjar traços evidentes que as distingam do resto da sociedade -, é mantida também pela transição do sistema simbólico-visual: antes afirmada pela abundância e primor de sua escravaria; depois demonstrada pelo requinte e opulência dos próprios senhores e senhoras, cada vez mais “civilizados” em suas roupas, etiqueta e idéias.

Pouco a pouco, a “antiga” negra é retirada dos retratos das crianças brancas; afinal as “ultrapassadas práticas da escravidão” não deveriam mais ser retratadas por este moderno meio que era a fotografia...

Essa série de retratos das amas expressa uma metáfora do que fora a escravidão: a princípio mostrada e publicizada com orgulho, e de rosto inteiro; depois escondida, colocada em segundo plano, desfocada e retocada, até ser retirada do (en)quadro nacional. ${ }^{36}$ Entretanto, mesmo que encoberta, ela persistiria nos hábitos consolidados durante mais de três séculos. Esses hábitos foram cultivados pela experiência de socialização infantil, que transmitiu uma memória

\footnotetext{
${ }^{35}$ Lilia Moritz Schwarcz, Op. cit. 1987. p.182.

36 “(...) nas palavras do próprio Militão, trata-se de “um povo de escravos” que, como tal, não deve ser focalizado, tanto por ser considerado cientificamente inferior, quanto porque, na iminência da abolição da escravatura, uma "má consciência” surge deste fato, relegando esta questão, paulatinamente, ao silêncio. E silêncio, na fotografia, é o nãofocalizado, o não-nítido, o que precisa de um esforço para ser visto.” Emília Viotti da Costa. Da senzala à colônia. São Paulo, Editora Unesp, 1998. p. 364 e Lilia Moritz Schwarcz, Op. cit. 1987 apud Íris Morais Araújo e Rafaela de
} 
de histórias, músicas, receitas e cuidados com o corpo e o espírito que continuaram reverberando até os dias de hoje. Se a escravidão, como instituição, era evidentemente aviltante, as relações humanas que se estabeleceram sob sua vigência, transcenderam seu perfil exclusivamente econômico. As amas foram, desse modo, sistematicamente sumindo das fotografias; tal como a escravidão, na representação oficial e nacional.

É de uma ambigüidade dilacerante que se compõe, portanto, essa relação social entre a mãe-preta e seu filho branco, expressa no laço afetivo entre pessoas pertencentes a diferentes status hierárquicos. Essas barreiras sociais foram, no entanto, transpostas no cotidiano do espaço privado do lar, quando a negra e escrava passou a ter poder sobre o filho branco de seu senhor e, até mesmo, autoridade dentro da casa senhorial. A tensão revela-se também na assimilação da escrava na família, nesse parentesco afetivo, mas sempre qualificado enquanto uma incorporação de segunda ordem... uma incorporação pelo trabalho. Como já anunciava a epígrafe desse trabalho: “imagem de uma relação paradoxal mas admitida”, que mescla amor e violência.

Tal experiência contraditória - entre amas negras e família branca - escasseou no tempo; porém, tem até a atualidade uma longa-duração simbólica. A presente dissertação de mestrado toma como objeto, justamente, essas representações da mãe-preta que reelaboram continuamente tal vínculo social do passado.

O conceito de "representação" utilizado nessa pesquisa assemelha-se àquele de “representação social” tal como definido por Durkheim.

Para o sociólogo, as representações são sociais, não apenas no sentido de terem sido produzidas pela sociedade, mas também por mediarem e produzirem a própria vida social. Nas palavras do autor: "mas, no que lhes diz respeito [às representações sociais], o problema é mais complexo, porque elas são sociais em outro sentido e como que em segundo grau. Elas não apenas derivam da sociedade, mas as coisas que exprimem são sociais”. ${ }^{37}$ Ou ainda, essas representações sociais "não se limitam a enriquecer, com certo número de idéias, um espírito humano previamente formado; elas contribuíram para formá-lo”. ${ }^{38}$

De tal modo, nessa dissertação, a representação social não é apenas fruto dos diferentes arranjos sociais (igualmente qualificados como “reais”); ela constitui, também, uma mediação

Andrade Deiab. Militão Augusto de Azevedo ou formação de um imaginário paulista: olhando retratos e vistas urbanas. 2002, mimeo.

${ }^{37}$ Émile Durkheim. As Formas Elementares da Vida Religiosa. São Paulo, Editora Paulus, 1989. p. 518

${ }^{38}$ Idem. p. 37 e 38. 
que participa da própria produção desses arranjos. O conceito é, portanto, produto social, ao mesmo tempo, que condição para a produção da vida social.

Nessa medida, as amas-de-leite - estudadas pela historiografia - apresentadas nessa introdução não se opõem (ou se separam) às suas próprias representações fotográficas ou sociais. As amas-de-leite "históricas” também eram compreendidas socialmente e mediadas por diversas representações: fossem como “a encarnação do alimento permeado de amor e dos cuidados afetuosos”; fossem como “espectro de doenças medonhas”. O fato é que não havia - e não há mães-pretas “reais” descoladas de suas representações. Como afirma Roger Chartier: “na verdade, é preciso pensar em como todas as relações, incluindo as que designamos por relações econômicas ou sociais, se organizam de acordo com lógicas que põem em jogo, em acto, os esquemas de percepção dos diferentes sujeitos sociais, logo as representações constitutivas daquilo que poderá ser denominado uma 'cultura', seja esta comum ao conjunto de uma sociedade ou própria de um determinado grupo.”39

Mas tomar as representações sociais nessa acepção implica em assumi-las como históricas e inclusive manipuláveis, ou seja, como sujeitas à modificações próprias a qualquer dinâmica social. "Assim; as representações não são um único conjunto que resiste às mudanças do tempo, ou como nos diz Peter Fry, 'não como um retrato fixo; mas antes imagens em movimento que guardam continuidade, mas que também admitem transformação' ", 40

Esse misto de continuidade e mudança, implicados na representação social, são compreensíveis na medida em que é salientado o seu caráter coletivo e as suas funções comunicadoras. As representações, por serem coletivas, possuem uma perenidade maior do que as representações individuais; além disso, devido a tal estabilidade, seus sentidos se mantêm mais ou menos os mesmos, de modo que a sociedade pode se comunicar fazendo uso de seus significados públicos.

Marshall Sahlins também atentou para este jogo entre reprodução e mudança dos sentidos culturais na História. Isso porque a cultura e seus significados se realizam na prática histórica, de modo que os agentes sociais, ao se relacionarem (ao praticarem sua cultura), sempre adaptam - e, portanto, modificam - os sentidos públicos previamente estabelecidos. Mas essas adaptações possíveis e comuns são limitadas pelas próprias possibilidades de significação das representações que, caso contrário, seriam ininteligíveis e perderiam sua função comunicadora. Segundo o autor,

\footnotetext{
${ }^{39}$ Roger Chartier. A História Cultural - entre práticas e representações. Lisboa/Rio de Janeiro, Difel/Bertrand Brasil, 1990. p. 66.

${ }^{40}$ Lilia Moritz Schwarcz, Op. cit. 1987. p.250.
} 
essa negociação se dá "na existência e interação dual entre a ordem cultural enquanto constituída na sociedade e enquanto vivenciada pelas pessoas: a estrutura na convenção e na ação, enquanto virtualidade e enquanto realidade. Os homens em seus projetos práticos e em seus arranjos sociais, informados por significados de coisas e de pessoas, submetem as categorias culturais a riscos empíricos". 41

As representações da mãe-preta que estudo, não são apenas aquelas dos inúmeros retratos em estúdio e, tampouco, as existentes durante a escravidão. Optei por analisar o extenso horizonte da literatura, que também carrega esses sentidos ambíguos da mãe-preta, alguns deles já mencionados nessa introdução.

Num vasto campo literário, a mãe-preta assume vários papéis paralelos. É mãe e não é; mãe natural e mãe social; preta e civilizada como uma branca; é boa e má; ingênua e portadora de grande saber; escrava e livre; faz parte da família, ao mesmo tempo, em que é apenas agregada; profundamente amada, mas incorporada mediante um trabalho desgastante e etc. Portanto, a figura da mãe-preta é, por definição, ambígua e múltipla; de modo que vou explorar justamente essa soma de facetas, ao passo em que tento entender como, após o final da escravidão, se dá a afirmação dessa imagem díspar, e como ela permanece por longa data ainda presente, a despeito do fim da instituição escravocrata. Em outras palavras, persigo as diversas representações da mãe-preta na literatura - sempre caracterizadas por suas ambigüidades -, partindo do cenário de iminência da abolição (1880), até meados de 1950, uma vez que é nesse intervalo em que se estabiliza uma interpretação mais alentada do que fora a escravidão brasileira. Ademais, é nesse contexto que se afirma essa representação, também (mas não só), na esfera oficial.

Este período que recortei possui como marcos extremos as obras que analiso nessa pesquisa: de 1881, data de publicação dos Poemas da Escravidão de Melo Moraes Filho; a 1954, quando vem a público Brasil - Canção, de Antonieta Borges Alves.

Este intervalo de tempo largo, porém controlável, que sucede imediatamente o fim da escravidão, tem a mãe-preta como figura exemplar que, por vezes, “positiva” uma memória da escravidão, ou mesmo de seu legado; por vezes, refaz sua versão mais negativa. Deste modo, nessa dissertação analiso a maneira como as inúmeras versões da representação da mãe-preta constituem uma memória coletiva sobre a escravidão, assim como refazem essa forma ambígua de lidar com o cativeiro humano no Brasil.

\footnotetext{
${ }^{41}$ Marshall Sahlins. Ilhas de História. Rio de Janeiro, Jorge Zahar, 1987/1999. p. 9.
} 
Essa memória social construída a partir da experiência íntima e profunda com a escravidão, eminentemente doméstica, é elaborada, sobretudo, a partir da figura da mãe-preta e de seu “cônjuge”, pai-joão. Desta maneira, preocupo-me menos com uma suposta "realidade histórica” das escravas domésticas e amas-de-leite, do que com as versões que essa memória da mãe-preta permite veicular. Tenho como hipótese que, seja como memória oficial, seja como memória popular ou do senso comum, ela permite fazer as pazes com recente passado escravocrata que, se não podia ser esquecido, podia ao menos ser lembrado em sua faceta mais íntima, afetiva e também dilacerante.

Essa memória em torno das representações da mãe-preta “dependeu de algumas

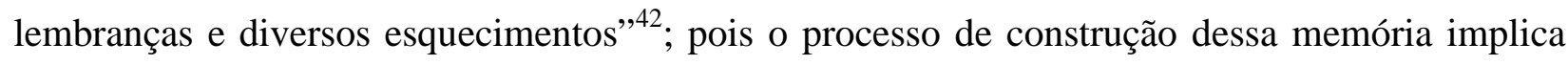
em uma seleção que reelabora determinadas imagens (permeadas por afetividade, santidade, gratidão) em detrimento de outras (que evocam violência, conflito). E essas “escolhas”, feitas ao longo do tempo, foram partilhadas socialmente - por certos grupos - uma vez que a memória para ser lembrada, tal como argumentava Maurice Halbwachs, tem que ser coletiva. Esse autor, seguidor da Escola Sociológica Francesa, também advertia para o fato de que as lembranças são sempre reconstruções do passado, influenciadas pelo momento presente da rememoração. Deste modo, o que se lembra depende muito do quando se lembra... Nas palavras do próprio Halbwachs: “a lembrança é, em larga medida, uma reconstrução do passado com a ajuda dos dados emprestados do presente, e além disso, preparada por outras reconstruções feitas em épocas anteriores e de onde a imagem do outro manifestou-se já bem alterada.”43 O momento presente em que se recupera a memória é, portanto, capital para sua reelaboração. Assim, a mãe-preta que surge na Primeira República - período que sucede a recente abolição da escravidão e que procura escamotear essa marca retrógrada, visando nos “civilizar” - diverge da mãe-preta lembrada pelo Estado Novo, nos idos dos anos 1930 - num momento marcado pela busca de uma identidade nacional que se queria, e se entendia, como sendo mestiça.

Cabe, ainda, um último esclarecimento ao leitor: utilizo o termo e a grafia "mãe-preta” para me referir a uma categoria genérica construída por mim no escopo da pesquisa e da documentação, e que se refere àquelas personagens remanescentes da escravidão, sobretudo mulheres ligadas ao universo da escravidão doméstica. Elas são, portanto, íntimas da família e, em geral, bem quistas pelas crianças brancas de que cuidam e, principalmente, para quem contam

\footnotetext{
${ }^{42}$ Lilia Moritz Schwarcz. As Barbas do Imperador. São Paulo, Companhia das Letras, 2000. p. 520.

${ }^{43}$ Maurice Halbwachs. A Memória Coletiva. São Paulo, Vértice, 1990. p.71.
} 
histórias. No entanto, para evitar a má compreensão, quando estiver analisando as fontes, utilizarei os termos tal como estão grafados no documento original, sempre entre aspas.

No intuito de realizar esses objetivos - recuperar a memória coletiva em torno das representações literárias da mãe-preta no período de 1880 a 1950 - percorro, neste trabalho o seguinte caminho:

Na introdução, busco de maneira breve o contexto histórico em que surge a figura da mãepreta e suas primeiras representações fotográficas e sociais. Neste momento, a mãe-preta, vinculada ao “próprio” filho branco, já aparece como uma personagem ambígua; incorporada na família branca mediante uma forte relação afetiva, mas que tinha como pré-requisito a escravidão. Em seguida, esclareço o recorte de meu material e minha questão.

Na primeira parte do trabalho, preparo o caminho para a análise das fontes. Tal “preparação” implica, na verdade, em dois movimentos: o primeiro deles (desenvolvido no “capítulo 1”) é um mapeamento das interpretações feitas das imagens das amas-de-leite negras com suas crianças brancas. Essas interpretações revelam-se não só diversas, como eminentemente contraditórias, o que acabou por me levar a uma pesquisa sobre o modo como a mãe-preta fora interpretada na historiografia da escravidão brasileira. Além disso, evidencio as diferenças entre a minha análise das representações literárias da mãe-preta daquelas feitas por esses pesquisadores.

O segundo movimento (realizado no “capítulo 2") traz uma ponderação sobre a diversidade do material escolhido para apreciação. Discorro sobre a heterogeneidade dessas fontes no que tange tanto à forma, quanto à importância dos autores. Além disso, examino a mediação feita pelos diferentes movimentos artísticos e contextos históricos culturais na incorporação da temática do negro na literatura, o que influenciou sobremaneira as representações da mãe-preta.

Na segunda parte da dissertação, empreendo uma leitura interpretativa das fontes. No “capítulo 3”, detenho-me, sobretudo, nas representações mais recorrentes da mãe-preta, revelando alguns de seus aspectos mais estruturais, mas salientando também seus sentidos diversos.

No “capítulo 4”, analiso um tipo específico de produção, trata-se da literatura infantil produzida nas décadas de 1920-1930, na qual a mãe-preta ou a “negra velha” contadora de histórias aparece como figura dileta ligada ao folclórico e ao popular. 
Já nas considerações finais, retomo os diferentes sentidos veiculados pelas mães-pretas a partir de uma etnografia da Missa da Mãe Negra; aventando, também, as hipóteses para a longa duração simbólica dessa figura. 


\section{Parte I}

Capítulo 1

Mãe-Preta: metáfora de uma discussão valorativa da escravidão

Capítulo 2

Versões brancas da mãe-preta 


\section{CApÍtulo 1}

\section{Mãe-Preta: metáfora de uma discussão valorativa da escravidão}

\section{Introdução}

Discutir as diferentes representações da mãe-preta constitui tarefa delicada. Isso porque, a mãe-preta vem sendo compreendida por diferentes autores e pesquisadores em sentidos contraditórios, na maior parte das vezes, associados a uma discussão valorativa da escravidão brasileira. Embora o estudo da mãe-preta ocupe um papel tangencial na obra desses intelectuais, suas conclusões sobre a personagem acabam por ser generalizadas para toda a instituição. Nessa medida, a mãe-preta ora é vista como prova de uma escravidão amena, ora como reveladora da crueldade e do arbítrio dos seus senhores. Para realizar uma revisão dos sentidos empregados por certa intelectualidade à personagem em questão, parto de suas apreciações sobre imagens semelhantes àquelas das quais tratei na Introdução deste trabalho chegando, em seguida, aos diferentes arcabouços teóricos que as sustentam.

\section{Retratos: qualificativos para a relação mãe-preta de filho branco}

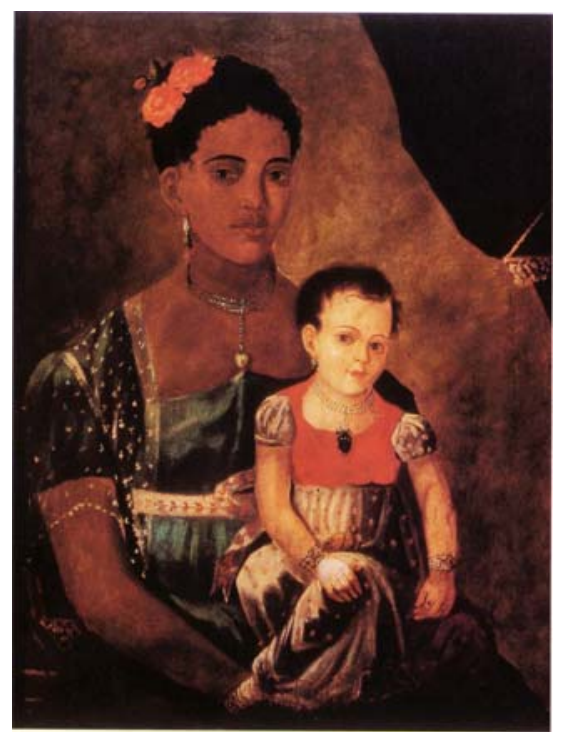

[FIGURA 9]

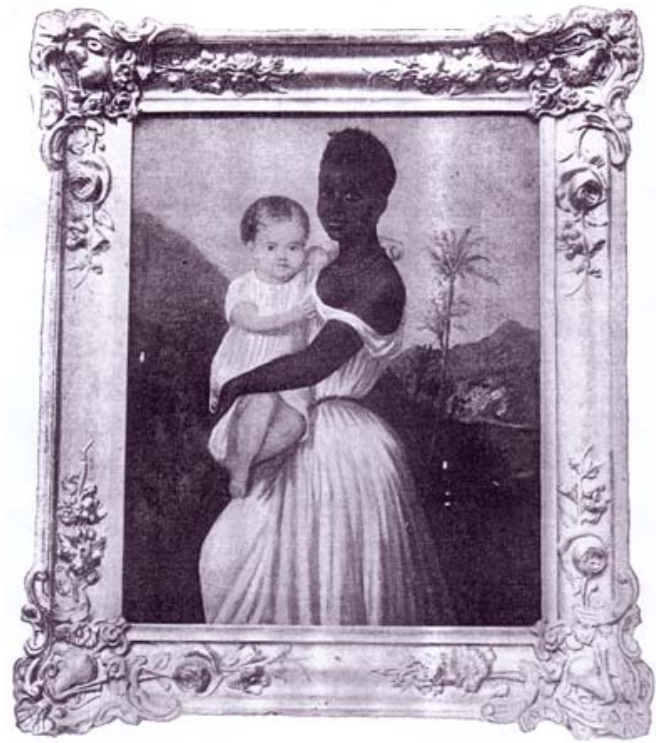

[FIGURA 10] 
Retratos, como os analisados, trazendo a ama negra e as crianças brancas, foram largamente produzidos em todo Brasil desde meados do século XIX. Mas já no princípio desse mesmo século são conhecidos retratos à óleo, que apresentam as mesmas amas negras com os pequenos brancos ao colo. Exemplo disso são as telas reproduzidas nas figuras acima [FIGURA 9 e FIGURA 10]. Essa última imagem, duvidosamente atribuída a Debret ${ }^{44}$, traria, segundo supõe o historiador Pedro Calmon ${ }^{45}$, D. Pedro II criança, no colo de sua ama. Verdade ou não, o fato é que essas imagens “insistem” em aparecer.

Esses riquíssimos e reincidentes documentos iconográficos tiveram uma vasta gama de interpretações. Por vezes eram interpretados como símbolos de uma relação íntima e harmoniosa, entre senhores e escravos. Em outros momentos, foram entendidos como a própria auto-imagem da classe proprietária que, por meio de escravos bem trajados, ostentava sua própria riqueza. Seriam ainda, reveladores de uma forma sinistra de exploração do corpo feminino e da negação de uma maternidade escrava. Todas essas explicações são, em parte, corretas, e nem tão contraditórias como podem parecer numa primeira impressão. O que elas fazem é dar relevo a certas dimensões específicas dessa relação ambígua e multifacetada entre ama escrava e os herdeiros da família patriarcal.

A interpretação desses retratos, como evidência de uma “escravidão mais benigna” existente no Brasil, ou no Nordeste, é reputada a Gilberto Freyre. Mas diferente do que se imagina, muitas vezes, ela não está presente em Casa-Grande \& Senzala ${ }^{46}$, mas em obras bem posteriores, mais especificamente na segunda edição de $O$ escravo nos anúncios de jornais brasileiros do século $X I X^{47}$, que fora acrescida de anexos, dentre os quais consta "Iconografia: Comentário”. É neste segmento, que o autor pernambucano vê nos negros e negras vestidos à européia uma comprovação iconográfica de uma “escravidão mais suave”, fazendo ainda, uso dos relatos de inúmeros viajantes para corroborar sua análise.

“Os fotografados seriam uma elite a destacar-se, por aparências correspondentes à sua efetiva situação social, da massa: uma aparência e uma situação de indivíduos que tivessem alcançado, pela alforria, o status de livres; ou fossem, como ainda escravos, mucamas, bás ou 'tios' sociológicos, dentro de hierárquicas casas-grandes brasileiramente patriarcais, e, como tal, indivíduos ou pessoas recipientes de privilégios quase de livres. Escravos paradoxalmente superiores, sob

\footnotetext{
${ }^{44}$ Esse questionamento sobre a atribuição da imagem e sobre a identidade do retrato está em Lilia Moritz Schwarcz. As barbas do Imperador. São Paulo, Companhia das Letras, 2000. p. 46.

${ }^{45}$ Pedro Calmon. Historia do Brasil vol. 5 - século XIX, o império e a ordem liberal. Rio de Janeiro, José Olympio, 1959. p. 1582.

${ }^{46}$ Gilberto Freyre. Casa-Grande \& senzala. Rio de Janeiro, Editora Record, 1933/2001.

${ }^{47}$ Gilberto Freyre. O escravo nos anúncios de jornais brasileiros do século XIX. São Paulo, Companhia Editora Nacional, 1961/1979. $2^{\text {a }}$ edição aumentada.
} 
vários aspectos - no trajo, nos adornos, no trato aparente ou ostensivo de suas pessoas -, a não poucos brancos livres da época." 48

Esses negros e negras, que surgem muito bem vestidos nos retratos, eram, segundo o autor, integrantes de uma pequena elite, mesmo se comparados aos brancos livres. Os protagonistas das imagens ainda que não fossem alforriados, em função de seus trabalhos prestados no interior da casa-grande, eram “assimilados” a essas “famílias brasileiramente patriarcais". Dentre essas funções promotoras de um "parentesco sociológico” entre senhor e escravo, temos as amas, mencionada no trecho como "bás”. Elas e outros escravos domésticos, em função desse status, teriam privilégios de “quase livres”. Privilégios esses que estariam estampados nos retratos por meio das roupas, adornos e “trato”, presentes na imagem desses negros.

Nesse tipo de raciocínio, a escravidão surge quase como um detalhe. Porque se os negros não são livres, têm acesso a privilégios de “quase livres”, e por isso essa não seria uma escravidão muito violenta e opressiva. Mas Freyre, prosseguindo sua argumentação, revela como os viajantes, entendidos pelo autor como “científicos e insuspeitos”, também tiveram essa interpretação diante da escravidão brasileira.

“A propósito das fotografias, aliás raríssimas, agora publicadas (...) recorde-se o que, acerca do porte, da figura, do semblante de escravos negros no Brasil do meado do século XIX vem testemunhado, com maior ênfase do que por outros observadores da época, por C. B. Mansfield, M. A. de Cambridge, no seu Paraguay, Brazil, and the Plate. Relembre-se este trecho, quase específico sobre o assunto (...): 'Now, the first thing that strikes me about these slaves, so far as I have seen them, is the dignity and independent look which they preserve'. Mais: '... I only wish such cheerful faces were to be seen among our English poor'. (...) O que o levaria a adiantar, já depois de um contato com o Rio de Janeiro, ter sido sua impressão das relações de senhores com escravos no Brasil a de que os escravos eram tratados 'considerably better than labourers in England'. Daí: 'There are even among the Blacks here some noble-looking fellows; and there is a curious air of independence about most of them; and they have a real independence...' "49

Os retratos dos negros e negras bem vestidos seriam, portanto, a versão iconográfica daquilo que fora descrito pelo viajante C. B. Mansfield: “negros com dignidade e olhar independente”, com faces mais “alegres” que os “pobres” trabalhadores ingleses, com aparência de "nobres” e ares de “independência”. Escravos assim, “independentes” e "belos”, só seriam possíveis se a escravidão brasileira não fosse tão “violenta”, e sim, “suave” e "benigna” a ponto

\footnotetext{
${ }^{48}$ Idem. p. 91. Grifos meus.

${ }^{49}$ Idem. p. 92 e 93.
} 
de os cativos serem tratados, segundo Freyre, consideravelmente melhor que os operários ingleses. Ainda na opinião do autor, outros viajantes teriam testemunhado a convivência entre senhor-escravo como sendo relativamente benigna. Cita, nesse sentido: Koster, Frezier, Lindley e Richard Burton.

Ainda tentando subsidiar sua interpretação, o escritor pernambucano sugere um estudo comparado de iconografia, de modo a qualificar a escravidão nas Américas inglesa, francesa e espanhola, e também a condição de vida das classes operárias na Europa.

"Seria interessante confrontar fotografias, quer de operários norteeuropeus dessa época, quer de escravos africanos, também do século XIX, em plantações e minas das Américas inglesa, francesa e espanhola com as de escravos no Brasil agrário-patriarcal, aqui apresentadas. Interessantíssimo, até, dado o fato da iconografia da espécie fotográfica ser tão expressivamente exata como documentação." 50

Nessas outras colônias onde a escravidão fora marcada por mais arbítrio, Freyre desconfia não existirem retratos de negros e negras tão bem vestidos e altivos, reveladores de um contato íntimo e suave com seus senhores, que os tratavam como membros da família patriarcal. Esse "trato ostensivo de suas pessoas" assim como sua alegria, tampouco seriam encontradas nas fotografias de operários norte-europeus. O autor salienta ainda, o caráter exato, tecnologicamente neutro, da fotografia, de modo a confirmar de maneira insuspeita suas conclusões. ${ }^{51}$ No entanto, ele omite a existência de outras espécies de retratos - nessa lógica, igualmente confiáveis - de escravos nem um pouco altivos, como aqueles realizados por Christiano Jr. na corte em meados do XIX. Nestas imagens os cativos posam no estúdio do fotógrafo, portando seus instrumentos de trabalho, e sequer encaram a câmara do fotógrafo. O que se vê nessas imagens comercializadas na Europa são “tipos” existentes no exótico escravismo tropical, muito distantes, portanto, daqueles indivíduos dignos e independentes descritos por Freyre. ${ }^{52}$

Ele encerra sua argumentação reafirmando a "benignidade” da escravidão brasileira, que pode ser inferida a partir dos retratos dos negros e negras ditos “aristocráticos”. Essas imagens são utilizadas, igualmente, como prova conclusiva da mesma hipótese:

“Parece, assim, de todo possível, sem desapreço pelo que considere objetividade científica no trato do assunto, admitir-se, nas relações predominantes - embora não exclusivas - entre senhores e escravos no

\footnotetext{
${ }^{50}$ Idem. p. 98.

${ }^{51}$ Já argumentei minha acepção sobre a fotografia como documento, que diverge muito desta expressa por Freyre. As fotos atestam a existência no passado daquela aparência, mas são produzidas de inúmeras formas. Seguem modelos de época, cumprem os desejos do cliente e tem sua fabricação dirigida por um fotógrafo que faz às vezes de artista.

${ }^{52}$ Estes retratos estão compilados em: Maurício Lissovsky e Paulo César de Azevedo (org.) Escravos brasileiros do século XIX na fotografia de Christiano Jr. São Paulo, Ex-Libris, 1988.
} 
Brasil patriarcalmente escravocrático, ter havido aspectos positivos a favor do que possa ser brasileiramente humanitário ou benigno nessas relações: e que teria tornado possível, em pleno viço daquele sistema de convivência entre senhores e escravos, que emergissem, dentre escravos, ou negros recentemente ou já há algum tempo livres, tipos sócio-antropológicos tão evidentemente caracterizados por uma 'dignidade' ou 'nobreza' de porte, por uma inconfundível ausência de ressentimento ou de humilhação nessas expressões de porte e em semblantes, fisionomias e sorrisos. Expressões das quais existem testemunhos fotográficos tão persuasivos." 53

Alegando seguir os critérios de objetividade científica, Gilberto Freyre assegura ainda, que os cativos manteriam certa "dignidade” e "nobreza” devido a uma relativa predominância 54 das relações "humanitárias” e "benignas” entre senhor e escravo no Brasil. Estas nuances da instituição escravista estariam visíveis, de modo revelador, nos retratos em questão. Por oposição a esse caso, nas colônias da Espanha, França e Inglaterra, onde não existiria esse "patriarcalismo suavizador”, o sistema escravocrata seria muito mais violento; e a iconografia dos negros revelaria tal evidência. Diferente do caso brasileiro, ver-se-ia nestes cativos ou recém-libertos apenas “ressentimento” e "humilhação".

Gilberto Freyre, dessa maneira, ao analisar os retratos das amas e de outros negros e negras vestidos à moda européia, conclui que seriam fruto de uma escravidão "mais amena”, existente no Brasil, mais especificamente no Nordeste. Essa seria “acessível”, sobretudo, aos criados domésticos, que em função do patriarcalismo escravista eram incorporados como “parentes sociológicos” da família branca; recebendo um tratamento muitas vezes raro aos próprios brancos livres. Nessa análise, o autor enfatiza, portanto, a "altivez” e a "independência” dos escravos domésticos - resultante da "benevolência branca” - e "suaviza” a escravidão que era, muitas vezes, a condição para a realização desses retratos.

Essa interpretação também surge em outros autores, que apresentaram retratos das amas negras com as crianças brancas. O vínculo íntimo entre ambos é sempre exaltado, fazendo com que, às vezes, a escravidão apareça como detalhe e não como pré-requisito para a realização do retrato. Na legenda, feita pelo historiador Pedro Calmon para aquela imagem (supostamente) de D. Pedro II com sua ama negra, é explícito um certo eco das posições do autor pernambucano:

“D. Pedro II, com ano e meio de idade, no colo de sua ama. Esse retrato a óleo, de Debret, simboliza os cuidados das mucamas com os filhos do senhor na vida patriarcal brasileira, quando as criança

\footnotetext{
${ }^{53}$ Gilberto Freyre. Op.cit. 1961/1979. p. 102. Grifos meus.

${ }^{54}$ Essas ressalvas, não raras no texto de Freyre, deixam entrever um diálogo com seus críticos. Tratarei deste debate um pouco mais adiante.
} 


\section{chamavam mãe-preta a essas escravas afetuosamente ligadas às famílias dos brancos. O bom exemplo era também imperial." ${ }^{25}$}

O retrato a óleo é considerado pelo historiador como uma evidência simbólica da ligação afetuosa entre a escrava e a família branca. Tal vínculo carinhoso fora promovido pelos cuidados extremados que a ama tinha com os herdeiros. Essa relação próxima e afetiva com as escravas domésticas é valorizada por Calmon, que faz do quadro e da família imperial bons exemplos a serem seguidos no que tange ao tratamento dos escravos ou criados negros. A liberalidade no trato e o afeto dispensados à criada tinham reflexos profundos no modo como ela era chamada pelas crianças brancas: “mãe-preta”. Reconheciam-na como uma espécie de mãe, tal qual o “parentesco sociológico” comentado por Freyre.

Na legenda, porém, não há sequer uma menção à escravidão; fala-se apenas da docilidade com que a negra (escrava) trata a criança, que lhe retribui de modo igualmente afetuoso. Há somente senhores bondosos acompanhados de cativos fiéis que fazem quase parte da família.

Um pouco desse foco na troca afetiva está presente na seguinte análise de retrato, feita mais recentemente, em 1999:

"Só se retratavam os entes muito queridos, os cabeças da família, as matriarcas. (...) Eras mais que apenas querida naquela família. Eras autoridade, mandavas e desmandavas nos que criaras e que logo se tornariam teus senhores. Conservarias sobre estes o poder de mãe. Deras-Ihe o leite e com ele parte da alma. Transmitindo-Ihes o mundo que trouxeras da África, com histórias do tempo em que os bichos falavam. Servias a todos com a dedicação daqueles que haviam escapado ao duro trabalho do eito para servir na Casa-Grande. Eras mãe de duas gerações. Não sabemos de quem fora a idéia. Mas conhecemos os motivos que te levaram a ser retratada para a eternidade. Que os sinhôs e sinhás que criaras pudessem mostrar a seus netos a querida rainha que foras no seio da família"56

A ênfase está na bondade e na permissividade da família senhorial, que retrata seu serviçal mais “querido e dedicado”, e quiçá por esta razão, poupado dos trabalhos no eito. Nessa relação, aparentemente muito afetuosa e cotidiana, a mãe-preta exercia sua autoridade de "mãe sociológica”, conquistada pelo aleitamento e pelas narrações de histórias de bichos falantes. Contudo, essa interpretação do retrato, ao convergir para a troca afetiva, acaba por vezes “amenizando” a condição escrava da mãe-preta. A analista, nessa medida, parece reproduzir em

\footnotetext{
${ }^{55}$ Pedro Calmon. Op.cit. p. 1582. Grifos meus.

${ }^{56}$ Luzilá Gonçalves Ferreira. "Um capítulo à parte: as amas de leite escravas” in: Luzilá Gonçalves Ferreira et alli. Suaves Amazonas: mulheres e abolição da escravatura no nordeste. Recife, Editora Universitária/UFPE, 1999. p. 174 e 175.
} 
seu artigo as explicações que a própria família patriarcal dava à fotografia e, também, os usos sociais que esse grupo fazia da imagem.

Outra interpretação existente é aquela que toma os retratos das amas negras com as crianças brancas como uma publicização do alto status social da família patriarcal. Isso significa fazer uso das intenções dos senhores - os clientes que encomendaram a foto - para solucionar o sentido da imagem. O viajante, professor e jornalista francês Charles Expilly, em 1853, já revelava esse mesmo raciocínio para justificar o fausto com que se vestiam as amas-de-leite brasileiras: "Entre os comerciantes da cidade é uma questão de amor próprio ter uma ama-de-leite que ostente um luxo insolente. Não é impossível, também, que seja uma especulação. O luxo da ama exprime a prosperidade da casa, a menos que sirva para tornar pública a verdadeira situação econômica (...)”. ${ }^{57}$ Por outro lado, Manuela Carneiro da Cunha, analisando outros retratos, para além de notar os desígnios senhoriais nos enfeites da escrava, identifica-os na imagem como um todo:

“(...) pois para tornar escravo um homem, cumpre anular todos os seus laços sociais prévios, na tentativa de fazer do senhor o único elo do escravo com o mundo. Daí a imagem padrão que o senhor quer ter do escravo: o da ama de leite negra com a criança branca no colo. A esta imagem opõe-se outra (...) que é uma obra-prima. É também a única, nesta série de hetero-retratos, que parece ser um auto-retrato, na medida em que transmite uma imagem de si mesmo. ${ }^{\prime 58}$

Segundo a antropóloga, a imagem da ama negra com a criança branca revelaria a imagem do escravo e da manutenção de sua escravidão. Isso porque a escravização, para a autora, implicaria na existência de pessoas cujos laços sociais prévios foram cortados e cujos novos têm invariavelmente a família patriarcal como mediadora. A escravidão aparece assim, com grande peso e crueza, evidenciando-se a ruptura brusca das relações dos africanos em suas comunidades, além da dependência social de seus próprios “algozes”.

Nesta acepção, a mãe-preta representa, de modo contundente, a própria estampa modelar da escravidão; uma vez que suas ligações sociais e afetivas são, nas fontes até aqui mencionadas, tecidas exclusivamente com os herdeiros da família senhorial. Ainda seguindo essa lógica, tais

\footnotetext{
${ }^{57}$ Charles Expilly. Apud Miriam Moreira Leite. Retratos de Família. São Paulo, Edusp, 2000.

58 Manuela Carneiro da Cunha. “Olhar Escravo, Ser Olhado”. In: Paulo Cesar de Azevedo e Mauricio Lissovsky (org.) Op. cit. p. XXX. Grifos meus. A outra imagem referida no trecho - que se encontra em anexo neste trabalho , que comenta os retratos em estúdio de Christiano Jr., traz uma escrava africana junto de uma criança negra, provavelmente sua filha. Esse é o único retrato em que a escrava olha diretamente para a câmara. Segundo a autora, ao posar ao lado da filha - um laço social próprio - a imagem se tornaria uma espécie de auto-retrato.
} 
retratos seriam, portanto, hetero-retratos, uma vez que expressam tão somente o arbítrio senhorial e não uma imagem onde as escravas também pudessem se reconhecer.

Contudo, essa interpretação, que confere maior relevo à escravidão como instituição, não consegue dar conta da troca afetiva também implicada nesse retrato. Esse mesmo peso na condição escrava está presente na análise dos retratos das amas escravas com as crianças brancas, feita pela historiadora Miriam Moreira Leite:

"Os retratos de amas-de-leite que conhecemos apresentam tão-somente a imagem positiva do relacionamento afetivo da ama vestida à européia, com o bebê branco ao colo. Mas é fácil verificar que (...) a prática da amamentação por escravas alugadas a particulares ou asilos de crianças abandonadas foi responsável por uma das formas mais sinistras de inter-relacionamento nos grupos de convívio. Além de privar os filhos de seu leite, as amas-de-leite eram exploradas fisicamente ao máximo, tanto quando eram alugadas a instituições para amamentar diversas crianças, como pelo período prolongado que se exigia que aleitassem." ${ }^{n 9}$

Discutindo com aquela primeira interpretação das imagens, presente em Gilberto Freyre, a autora contra-argumenta trazendo à tona a violência e a exploração inscritas na relação entre a ama escrava e a criança branca. A ama escrava é caracterizada a partir do abuso constante, uma vez que nega seu leite ao próprio filho, assim como amamenta diversas crianças por longos períodos de tempo. A imagem da mãe-preta implicaria, portanto, em um filho preto - uma relação social própria, nos termos de Manuela Carneiro da Cunha - preterido em função do arbítrio senhorial. Miriam Moreira Leite não deixa, desse modo, nenhum espaço para uma versão "positiva” da relação entre ama negra e criança branca, centrando-se, ao contrário, no seu caráter “sinistro”, marcado pela exploração do corpo, da saúde e da maternidade da escrava. Mas, ao fazê-lo, também não trata da troca afetiva existente entre esses personagens. Não se tratando de uma relação exclusivamente hierárquica, a densidade da experiência está na sua ambivalência.

As análises de retratos aqui revisadas são muito diversas e até mesmo contraditórias, o que de algum modo apresenta a dificuldade que a iconografia impõe ao pesquisador. Descobrir significados e retóricas da imagem, quase nunca é um exercício fácil e compreendido com transparência. A comunicação de significados por meio de imagens revela-se mais aberta e, paradoxalmente, duvidosa para os pesquisadores em geral, treinados e habituados a trabalhar com documentos escritos, cujos sentidos não são menos duvidosos, ainda que de outra natureza.

\footnotetext{
${ }^{59}$ Miriam Moreira Leite. Op.cit. p. 69 e 70. Grifos meus.
} 
Além disso, a própria ambigüidade da relação existente entre a ama escrava e a criança branca - onde afeto e violência são interdependentes - faz com que diversas interpretações sejam possíveis. Isso acontece ao se enfatizar parcelas distintas desse vínculo paradoxal, podendo-se atribuir diferentes significados para os retratos que estampam a mãe-preta e o seu filho branco. Quando o argumento valoriza a troca afetiva, surge a interpretação de uma escravidão mais doce, junto aos senhores paternais. Porém, se a ênfase está no "peso" da escravidão, os retratos mostrariam o escravo a partir da perspectiva senhorial: um ser “assimilado” à família branca - o que levaria a uma negação das relações sociais exteriores a esse núcleo. Mas quando o foco está na negação da maternidade natural da negra escrava, as imagens revelariam uma exploração do corpo da ama.

Todas essas interpretações são, portanto, corretas, mas também parciais. Contudo, dar relevo a determinadas parcelas da relação entre a mãe-preta e o filho branco não é um movimento interpretativo feito de maneira incauta pelos pesquisadores. Cada um deles faz uso de diferentes arcabouços teóricos, que implicam em modos peculiares de estudar a escravidão no Brasil ${ }^{60}$. Portanto, é possível dizer que a relação entre a ama escrava e a criança branca foi analisada como metáfora da escravidão - fosse ela caracterizada como "suave” ou “cruel” - dependendo da maneira como cada um desses intelectuais a concebia em seus trabalhos.

Deste modo, é preciso notar como a reiteração dessa imagem (da mãe-preta com seu filho branco) é reveladora e merece atenção. Com efeito, se sua explicação fosse evidente, há muito teriam se interrompido as interpretações. De fato, a ambivalência continua a pedir atenção.

\section{A mãe-preta e a historiografia da escravidão}

Gilberto Freyre, em Casa-Grande \& Senzala ${ }^{61}$ dá um papel de extrema relevância para as amas negras $^{62}$, ressaltando a relação afetiva e de troca cultural promovida pela escravidão. Ele revela também um padrão de relacionamento racial particular, que não se resolvia pelas teorias racistas ou higienistas. Ao tomar esse partido teórico, o autor assumia certa posição de vanguarda no pensamento social brasileiro que, nos idos de 1933, ainda era muito marcado por interpretações racialistas.

\footnotetext{
${ }^{60}$ São muitas as revisões bibliográficas sobre os estudos da escravidão no Brasil. Cito aqui as duas de que mais me utilizei: Lilia Moritz Schwarcz e Lúcia Garcia. "Nem bem passivos, não só heróis: sobre a lógica da negociação” in: Lilia Moritz Schwarcz e Lúcia Garcia (org.) Registros escravos: repertório das fontes oitocentistas pertencentes ao acervo da Biblioteca Nacional. Rio de Janeiro, Fundação Biblioteca Nacional, 2006. Robert Slenes. Na Senzala, uma flor. Rio de Janeiro, Nova Fronteira, 1999. Especialmente o capítulo 1 "Histórias de família escrava”.

${ }^{61}$ Gilberto Freyre. Casa-Grande \& senzala. Op. cit. 1933/2001. Principalmente capítulos 4 e 5.
} 
O ensaísta, ao eleger a mãe-preta como um dos espaços privilegiados de influência da cultura negra sobre a portuguesa, permite identificar, em alguns momentos do seu texto, uma certa imagem de senhores mais paternais e de escravos bem-cuidados, fiéis, e "quase da família”. Estes elementos estão presentes na seguinte descrição:

"Quanto às mães-pretas, referem as tradições o lugar verdadeiramente de honra que ficavam ocupando no seio das famílias patriarcais. Alforriadas, arredondavam-se quase sempre em pretalhonas enormes. Negras a quem se faziam todas as vontades: meninos tomavamIhe a bênção; os escravos tratavam-nas de senhoras; os boleeiros andavam com elas de carro. E dia de festa, quem as visse anchas e enganjentas entre os brancos da casa, havia de supô-las senhoras bemnascidas; nunca ex-escravas vindas da senzala. É natural que essa promoção de indivíduos à Casa-Grande, para o serviço doméstico mais fino, se fizesse atendendo a qualidades físicas e morais; e não à toa e desleixadamente. A negra ou mulata para dar de mamar a nhônhô, para niná-lo, preparar-lhe a comida e o banho morno, cuidar-lhe a roupa, contar-Ihe histórias, às vezes substituir-Ihe a própria mãe - é natural que fosse escolhida dentre as melhores escravas da senzala. Dentre as mais limpas, mais bonitas, mais fortes." ${ }^{13}$

Nessas passagens - em que escravas bonitas, limpas e fortes ascendiam ao serviço da casa-grande, cuidando da prole senhorial, e sendo bem tratadas ou até mesmo alforriadas, mas permanecendo junto da família patriarcal em lugar de honra - depreende-se uma imagem da escravidão repleta de senhores benevolentes e escravos (ou ex-escravos) fiéis nos engenhos de açúcar do Brasil ${ }^{64}$.

No entanto, Gilberto Freyre, na análise que realiza ainda em 1933, não foi tão homogênea e previsível. Em outros momentos do livro, ele denuncia e analisa a violência existente nesse sistema de relações entre casa-grande e senzala; fala do sadismo dos senhores, dos castigos e das doenças que acometiam os escravos. Essa ambigüidade latente em sua interpretação do Brasil Colonial revela, portanto, a constrição essencial da forja dessa cultura brasileira mestiça tão rica: essas trocas culturais entre brancos e negros se davam mediante uma relação hierárquica, a escravidão; jamais entre iguais. É dessa desigualdade de princípio que surgiria a particularidade brasileira enquanto civilização, levando a um privatismo exacerbado que qualifica nossas relações sociais como paradoxais, repletas de tensão, violência e, também, proximidade. É esse

\footnotetext{
${ }^{62}$ Para nomear essas negras Freyre faz uso de diversas categorias: escrava, sinhama, mucama, negra velha, mãepreta, bás, mulata, ama, ama-de-leite e etc.

${ }_{63}$ Gilberto Freyre. Op.cit. 1933/2001. p. 406.

${ }^{64}$ Essa é a interpretação canônica da obra de Freyre e com a qual discutem aqueles que estudam a escravidão no Brasil. Tratarei desse debate mais adiante. No entanto, uma outra crítica mais contemporânea tem recuperado a obra dos anos 1930 desse autor, pondo em foco seu paroxismo e ambigüidade. É com ela que passo a dialogar sobre o papel central da mãe-preta em Casa-Grande \& Senzala.
} 
“equilíbrio de antagonismos”65, que matiza violência com doçura, que marca as relações da casagrande com a senzala - da ama com o filho do senhor - e quiçá as relações sociais brasileiras de uma maneira mais geral.

Freyre fez, portanto, nesse seu primeiro ensaio, uma análise que não se limita (embora trabalhe com) a determinismos raciais e relações de poder, chegando a uma sociabilidade e convivência possíveis entre status sociais distintos. Dessa forma, sua obra se sustenta em uma acomodação de conflitos. E a ama negra, por meio de seu afeto pelo filho do senhor, é uma das agentes promotoras desse precário equilíbrio.

A historiografia nacional esteve muito influenciada pelas obras de Freyre até meados de 1950. Mas, progressivamente, desde meados da década de $1940^{66}$, sua obra começa a ser criticada. Essas críticas eram em grande parte motivadas por posicionamentos políticos que combatiam, sobretudo, a "tese da suave escravidão brasileira”, que ficava cada vez mais explícita, e menos matizada pela violência, na produção do autor. ${ }^{67}$ Além disso, essa "escravidão mais amena” era reputada ao colonizador português, e generalizada para todos os seus empreendimentos coloniais, o que demonstra uma clara aproximação de Freyre com o regime salazarista em Portugal. “A ênfase de Prado na dissolução moral do escravo e, em seguida, na devassidão geral de todos os grupos sociais obedecia a uma estratégia política: contribuía à condenação do legado socioeconômico do sistema colonial português, que Freyre, apesar das ambigüidades de sua análise, insistia em defender. Nas décadas posteriores, os autores que concordavam com Prado tinham mais motivos ainda para adotar essa estratégia. De um lado, havia o crescente prestígio de Casa-grande e senzala e de seu autor, este agora elogiando em tons muito menos matizados 'o mundo [de convivência racial harmoniosa] que o português criou', e defendendo, inclusive, a política salazarista na África portuguesa.”68

Florestan Fernandes foi quem passou a criticar mais abertamente o controvertido autor pernambucano. Especificamente em sua obra A Integração do Negro na Sociedade de Classes ${ }^{69}$, o sociólogo paulista, a partir de estudos empíricos em São Paulo, revê as posições do autor pernambucano, sobretudo no que tange às suas qualificações da escravidão. Ela não teria sido

\footnotetext{
${ }^{65}$ O termo está na própria obra de Freyre. No entanto, Ricardo Benzaquem, ao destacá-la, fez uso dela como sendo uma categoria teórico-explicativa. Ricardo Benzaquem Araújo. Guerra e Paz. Casa-Grande \& senzala e a obra de Gilberto Freyre nos anos 30. Rio de Janeiro, Editora 34, 1994.

${ }^{66}$ Em 1942, Caio Prado Junior lançou Formação do Brasil Contemporâneo em discutia criticamente com Gilberto Freyre. Caio Prado Junior. Formação do Brasil Contemporâneo. São Paulo, Brasiliense, 1942/1987.

${ }^{67}$ Os resultados dessa tendência foram apresentados quando discuti suas análises dos retratos em $O$ escravo nos anúncios de jornais brasileiros do século XIX.

${ }^{68}$ Robert Slenes. Op.cit. p. 30.

${ }^{69}$ Florestan Fernandes. A integração do negro na sociedade de classes. São Paulo, Ática, 1964/1978.
} 
harmônica, "branda”, ou “benigna”. Florestan Fernandes argumenta que o sistema escravista sempre e incondicionalmente faz uso da violência e da opressão e que, dentro dele, promove-se um processo de "coisificação” do escravo. Nessa medida, esses cativos "mercadorias”, sob um arbítrio senhorial extremamente violento, não conseguiriam estabelecer laços sociais próprios de solidariedade, como famílias ou grupos religiosos, de modo a possuírem qualquer relevância histórica no processo político de sua própria libertação, ou mesmo na história do país. ${ }^{70}$

Outros estudos da década de 1960, que traziam a idéia de “resistência escrava”, também se contrapunham a Gilberto Freyre - e a sua teoria da escravidão composta por senhores paternais

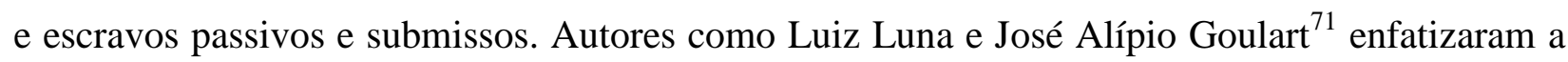
violência da escravidão e a sua contrapartida, composta por escravos rebeldes e bravos, que corajosamente combatiam tal instituição opressora. Contudo, essa abordagem acabou por fazer dos cativos verdadeiros "heróis românticos” ao dar destaque para o caráter heróico do escravo. ${ }^{72}$

Uma mistura dessas duas correntes de pensamento ("Escola de Sociologia Paulista”73 e “Resistência escrava”) que reagiram ambas às interpretações de Gilberto Freyre, está presente na análise que Sonia Maria Giacomini faz das mães-pretas, em Mulher e Escrava: uma introdução histórica ao estudo da mulher negra no Brasil ${ }^{74}$. Nesse livro, a autora se propõe analisar a situação da mulher escrava de modo “realista”, contrapondo-se às “ideologias” freyrianas, que permeavam a historiografia da escravidão, escamoteando sua exploração:

"Quanto ao primeiro [silêncio sobre as mulheres], ele aparece travestido na mitologia sobre a natureza doce e patriarcalista do escravagismo brasileiro. Mas é interessante notar que esta mitologia não se limita a produzir uma imagem deformada da relação senhor-escravo. Isto porque, na sua lógica a mulher escrava ocupa um papel central: 'ponte entre duas raças', 'embaixadora da senzala na casa-grande, e viceversa', e outras coisas do gênero. Em outras palavras: as relações senhorescrava, senhora-escrava, filhos brancos-escrava jogam um papel estratégico na estruturação de teorias sobre o patriarcalismo da escravidão brasileira." 75

\footnotetext{
${ }^{70}$ Lilia Moritz Schwarcz e Lúcia Garcia. Op. cit p. 11 e Robert Slenes. Op. cit p. 30 e 31.

${ }^{71}$ Luiz Luna. O negro na luta contra a escravidão. Rio de Janeiro, Leitura, 1968. José Alípio Goulart. Da palmatória ao patíbulo: castigos de escravos no Brasil. Rio de Janeiro, Conquista, 1971. José Alípio Goulart. Da fuga ao suicídio: aspectos da rebeldia de escravos no Brasil. Rio de Janeiro, Conquista, 1972.

${ }_{72}$ Lilia Moritz Schwarcz e Lúcia Garcia. Op. cit. 2006. p. 12 e Lilia Moritz Schwarcz. Retrato em branco e negro. São Paulo, Companhia das Letras, 1987. p.21.

${ }^{73}$ Composta por Florestan Fernandes e seus alunos entre os quais se encontram Otávio Ianni e Fernando Henrique Cardoso.

${ }^{74}$ Sonia Maria Giacomini. Mulher e escrava: uma introdução ao estudo da mulher negra no Brasil. Petrópolis, Vozes, 1988.

${ }^{75}$ Idem. p. 19.
} 
Segundo Giacomini, Freyre construíra $^{76}$, para além de uma versão distorcida (mitológica ${ }^{77}$ ) sobre o caráter da escravidão brasileira - como sendo patriarcal e doce -, uma imagem incorreta da mulher escrava em geral, descrita como "ponte entre as duas raças” ou ainda, “embaixadora da senzala na casa-grande e vice-versa”. E são justamente essas relações entre a família patriarcal e a escrava que serviam de metáfora da escravidão. Para se contrapor ao autor pernambucano, a antropóloga enfatiza, ao longo de todo o seu livro, a exploração a que estava submetida a mulher escrava, durante a vigência de tal instituição.

Nessa medida, argumenta que as baixas taxas de natalidade das escravas no Brasil (enquanto esteve ativo o tráfico) são frutos da preferência dos senhores pelo seu potencial produtivo, em detrimento de sua capacidade reprodutiva. Assim, negras grávidas continuavam no mesmo regime de trabalho pesado e forçado. Nesse cenário de extrema violência, os infanticídios e abortos promovidos pelas escravas são interpretados como uma "resistência escrava”. Desse modo, a relação é resumida na chave exclusiva da exploração.

No que tange à família escrava, Giacomini, tal como Florestan Fernandes, conclui pela sua inexistência:

"A noção de privacidade e de família refere-se a uma esfera própria que o escravo não possui por sua condição de coisa. Constituir família, ter uma prole é algo inacessível àqueles que não possuem nem a si próprios". ${ }^{78}$

Os escravos na sua qualidade de “coisa” seriam, segundo a autora, anômicos. Seres desprovidos de laços de solidariedade ou sequer de parentesco, e esta condição era reputada unicamente ao arbítrio senhorial. Isso porque o casamento significaria para seus patrões “uma limitação à mobilidade de sua 'mercadoria-escravo', o que os levava a desencorajar as uniões permanentes, sobretudo após 1869, quando a separação de escravos casados, pela venda, tornavase ilegal”. ${ }^{79} \mathrm{O}$ abuso sexual a que as escravas eram submetidas também é abordado. A própria potencialidade sexual da mulher escrava e de seu corpo, no limite, poderiam ser apropriados

\footnotetext{
${ }^{76}$ Uma crítica mais direta a Freyre, discutindo detidamente trechos de Casa-Grande \& Senzala, foi feita pela autora em: Sonia Maria Giacomini e Elizabeth K.C. de Magalhães. "A escrava ama-de-leite: anjo ou demônio" in: Carmen Barroso e Albertina Oliveira Costa (org.) Mulher, mulheres. São Paulo, Cortez Editora/ Fundação Carlos Chagas, 1983.

${ }^{77}$ Mito tem aqui o sentido de ideologia, de falsidade e ocultamento da realidade. E foi utilizado nesse mesmo sentido por Florestan Fernandes, no livro A integração do negro na sociedade de classes (Op. cit.), capítulo 1 - "O mito da 'democracia racial' ” da parte III do livro, intitulada: "Heteronomia racial na sociedade de classes”. Nesse segmento, o autor se dedica a desconstruir o "mito da democracia racial brasileira".

${ }^{78}$ Sonia Maria Giacomini. Op. cit. 1988. p. 29.

${ }^{79}$ Idem. p. 41.
} 
pelos senhores, dada sua condição de escrava-coisa. ${ }^{80}$ Para além disso, as determinações patriarcais da sociedade - que ditavam a dominação do homem pela mulher - legitimariam ainda mais a exploração da escrava, que além de propriedade privada era mulher.

Uma relação violenta entre a escrava e a senhora branca seria, igualmente, resultante dessa dominação patriarcal da sociedade, a qual repartia de maneira antagônica os papéis sexuais femininos. "Físico e sexualidade de senhoras e escravas funcionaram na sociedade patriarcal escravista de forma antagônica. Num a sexualidade está reduzida à procriação através das relações de parentesco; noutra, destaca-se a apropriação como objeto sexual do branco, ao mesmo tempo em que se nega ou se ignora a maternidade e a possibilidade de relações familiares. Senhoras, mães, castas, puras e brancas contrapõem-se a escravas, infanticidas, sensuais, lascivas, imorais, sem religião e negras.”,

Mas essa senhora branca de papel sexual reduzido e ocupada na administração do lar supervisionando as escravas domésticas, numa espécie de papel de um “feitor feminino”, era comumente descrita como ciumenta, violenta e sádica. ${ }^{82}$ Faziam uso da palmatória, do chicote, viviam aos gritos e xingamentos, castigando as escravas - sobretudo aquelas que eram alvo da lascívia de seus maridos - nas partes identificadas ao seu poder de sedução: bunda, dentes, orelhas e face.

Giacomini evidencia, ao longo dos capítulos de seu livro, as diversas explorações impingidas contra a mulher escrava. Destaca desde a negação de sua procriação e família próprias, até os abusos sexuais cometidos pelos seus senhores, além dos castigos físicos mandados realizar por suas esposas ciumentas. A antropóloga, opondo-se aos argumentos de Freyre, defende que as relações entre senhor-escrava e senhora-escrava - que tinham papel estratégico para qualificação da escravidão brasileira - eram notadamente marcadas pela opressão e pelo arbítrio.

Restava, ainda, demonstrar que também eram violentas as relações entre filhos brancosescrava, e assim a autora lançaria por terra a teoria de uma "escravidão doce”, em que as mulheres escravas eram as “embaixadoras da senzala na casa-grande”.

Giacomini começa sua argumentação mostrando como as próprias famílias brancas, a partir de 1850, viam com reservas as amas-de-leite escravas, temendo serem elas "agentes corruptores de suas famílias”. Transcrevendo trechos de jornais, onde diversos médicos e

\footnotetext{
${ }^{80}$ Idem. p. 65.

${ }^{81}$ Idem. p. 77.
} 
educadores apontam como maléfica a influência dos escravos negros nos lares brancos, Giacomini, de princípio, anuncia que nem mesmo a elite branca, que explorava essa "mão-deobra”, via apenas de modo idílico a relação entre ama negra e criança branca.

Em seguida, analisando uma série de anúncios de compra, venda e aluguel de escravas, mostra que ser mãe-preta de filho branco implicava na negação da maternidade do próprio filho natural das amas. Isso porque os anúncios que oferecem as escravas enfatizam "sem cria” ou sequer mencionam sua existência. As crias das escravas seriam utilizadas apenas para a manutenção da “capacidade de aleitamento da ama”, até o momento em que a senhora branca desse à luz. Então, a maior parte dos moleques era levada, a mando do senhor, para a Roda. Nessa medida, argumenta a autora, que a mera existência das mães-pretas é reveladora de violência e expropriação contra a mulher escrava:

“A existência das 'mães-pretas' revela mais uma faceta da expropriação da senzala pela casa-grande, cujas conseqüências inevitáveis foram a negação da maternidade escrava e a mortandade de seus filhos. Para que a escrava se transformasse em mãe-preta da criança branca, foi-lhe bloqueada a possibilidade de ser mãe de seu filho preto. A proliferação de nhonhôs implicava o abandono e a morte dos moleques.

Desta forma, ao incorporar a negra ao ciclo reprodutivo da família branca, a escravidão reafirmava a impossibilidade para os escravos de constituírem seu próprio espaço reprodutivo." ${ }^{83}$

Mas se as mães-pretas são, tão somente, sinônimo da expropriação e do autoritarismo senhorial, como poderiam ser tão correntes as representações que encontram nelas exemplos de doação, carinho e maternidade dedicada? Giacomini resgata, então, alguns artigos de jornais nos quais existem imagens positivas da figura, alegando serem minoria.

“A figura da 'mãe-preta' suscita diferentes reflexões nas nossas fontes. Privilegiado 'exemplo de corrupção' na maior parte de nossas referências, mas também 'alma de sentimentos extraordinariamente nobres' e 'coração transbordando de sublimes dotes' em outros textos, a ama-de-leite parece ser figura de proa nas 'inevitáveis' conclusões a que chega cada autor". ${ }^{84}$

Mas a autora realiza uma exegese destas representações, marcadamente diversas, da mãepreta e novamente polemiza abertamente com Freyre:

"O componente subjetivo presente nos atos de amamentar, ninar, cuidar do filho do senhor, serve em cada caso, negado, diluído, aumentado, à conformação de visões específicas: seja na visão racista e

\footnotetext{
${ }^{82}$ Idem. p. 80. Aqui, a autora que via em Freyre apenas uma versão da doce escravidão, apropria-se de uma passagem em que o autor pernambucano trata da violência e sadismo presentes na relação entre escravo-senhor.

${ }^{83}$ Idem. p. 58. Grifos meus.

${ }^{84}$ Idem. p. 63.
} 
etnocêntrica, que só reconhece a subjetividade da escrava na sua 'nefasta influência' nas crianças brancas, seja na visão da 'boa ama' enunciada em nossas fontes, cuja expressão acabada em nossos dias é a obra da Gilberto Freyre. Exacerbando ao extremo o componente subjetivo principalmente nas relações ama-de-leite/criança branca, edifica esse autor a conhecida imagem de escrava 'embaixadora da senzala na casagrande e vice-versa'.

Os estereótipos construídos em torno da figura da 'mãepreta' desempenharam e desempenham papel estratégico nas diferentes visões quanto à natureza da escravidão em nosso país. O interessante a destacar é que as bases materiais que sustentaram a existência das 'mães-pretas' são omitidas, centrando-se a atenção no investimento subjetivo da escrava no desempenho das funções de amade-leite. Que essa subjetividade seja ignorada, afirmada ou diluída, continuamos frente a análises absolutamente subjetivas da subjetividade da escrava." ${ }^{85}$

Para Giacomini, os diversos significados que recobrem a figura da mãe-preta se justificariam pelos diferentes sentidos dados ao "componente subjetivo" presente no cuidado da ama escrava com o filho da família senhorial. Caso esse “componente subjetivo” fosse negado, a negra surgiria como influência deletéria na educação e na saúde do bebê; se ele fosse aumentado, a ama apareceria como figura memorável de boa escrava, que faria a ponte entre as raças e as culturas. Seguindo tal raciocínio, são as ênfases peculiares dadas ao “componente subjetivo da relação” que levariam a conclusões tão díspares sobre o “caráter da escravidão brasileira”.

Mas, segundo a autora, permanecer no nível dos “componentes subjetivos” significa manter-se na ideologia - em “análises absolutamente subjetivas da subjetividade escrava”. Um passo além seria dado ao se “destacar as bases materiais que sustentaram a existência da 'mãepreta'” ; foi justamente isso que a autora pretendeu fazer ao mostrar como, mediante o modo de produção escravista, “a mãe-preta foi mãe da criança branca e não de seu filho preto”, ${ }^{86}$

Pode-se dizer sobre as análises desenvolvidas por Sonia Maria Giacomini, que pretendendo combater as teorias sobre a suposta "amenidade da escravidão brasileira” (cuja metáfora privilegiada seriam as relações entre mulher escrava e família senhorial, sobretudo a relação entre ama-de-leite e criança branca), ela demonstrou o quão violento e opressor era esse sistema, a ponto de não deixar possibilidades para a existência de uma família escrava e, sequer, para a maternidade escrava. Assim sendo, ela centrou seu argumento nas "bases materiais de vida da mulher escrava”. Nessa medida, as interpretações da mãe-preta que rivalizam com a interpretação da autora - tanto a representação higienista, quanto a culturalista de Freyre - só

\footnotetext{
${ }^{85}$ Idem. p. 63 e 64.

${ }^{86}$ Esse é um subtítulo de uma parte do artigo da autora, em que ela trabalha com os anúncios das amas nos jornais do XIX. Sonia Maria Giacomini e Elizabeth K.C. de Magalhães.Op. cit. 1983. p. 77.
} 
existem porque se atêm aos “elementos subjetivos” envolvidos nos cuidados da ama negra para com a criança branca entre eles: a amamentação, as canções de ninar, as histórias etc.

No entanto, a antropóloga, ao tentar legitimar seu argumento sobre a mãe-preta em detrimento dos outros existentes, instaurou uma precedência da realidade (das bases materiais) sobre a representação (a “ideologia” ou os demais componentes subjetivos), hierarquia essa que pouco se sustenta. Isso porque a Antropologia é uma disciplina que toma a dimensão simbólica logo as representações e significações - como parte constitutiva da ação do homem no mundo, inclusive na produção das bases materiais de sua existência. Como argumentou Eunice Durham em seu artigo “Cultura e Ideologia”: “(...) ação e representação aparecem indissoluvelmente ligadas, numa concepção de prática significante, [portanto] a antropologia não desenvolveu nenhuma tendência a opor formalmente 'condições reais de existência' às representações, nem a perceber estas como manifestações distorcidas daquelas. Dentro da orientação antropológica, é impossível relegar o universo simbólico, em sua totalidade, à instância de superestrutura, uma vez que ele é indissociável de qualquer prática social, inclusive da produção material, e é o instrumento fundamental para sua decifração. Voltada para o plano das práticas sociais concretas, a antropologia jamais operou satisfatoriamente com a oposição infra-estrutura/super-estrutura.”87

Acredito, deste modo, que relegar essa insistente e generalizada interpretação da relação entre mãe-preta e filho branco - como sendo positiva e marcada por afetividade - a “componentes subjetivos” que levam a interpretações ideológicas, não dá conta da questão. Pois caso a solucionasse, uma vez que tivessem sido analisadas sob o viés "revelador" das bases materiais, os tais “mitos” - da boa escravidão e da mãe-preta símbolo de doação e carinho deixariam de existir e de fazer sentido. No entanto, não foi o que aconteceu. ${ }^{88}$ Essas representações, mesmo depois de desconstruídas pelas abordagens que dão precedência às bases econômicas, continuam a ser re-significadas. Portanto, ver na mãe-preta apenas a violência da escravidão não dá conta das trocas estabelecidas entre ela e a família patriarcal; assim como, tampouco, explica a insistência dessa figura no imaginário e na memória nacional.

Retorno, agora, ao balanço historiográfico sobre a escravidão que eu vinha fazendo, e que incluía, também, uma revisão sobre as interpretações da mãe-preta.

\footnotetext{
${ }^{87}$ Eunice Durham. “Cultura e Ideologia” in: A Dinâmica da Cultura. São Paulo, Cosac \& Naify, 1984/2004. p. 262. Sobre as relações da antropologia com o marxismo consultar Marshall Sahlins. Cultura e Razão Prática. Rio de Janeiro, Jorge Zahar Editor, 2003.

${ }^{88} \mathrm{Na}$ próxima parte dessa dissertação trabalharemos inúmeras fontes que demonstram uma insistência na figura da mãe-preta, na literatura, ao longo do século XX.
} 
O que se pode dizer é que o quadro existente ao longo da década de 1960 era dominado pelas duas abordagens - aquela da chamada "Escola de Sociologia Paulista” e a que insistia na concepção de uma "resistência escrava" - que rechaçavam a interpretação freyreana, ambas enfatizando exclusivamente a violência e a opressão do sistema escravista. Para a Escola Paulista, a decorrência desse sistema seria uma certa "patologia” na personalidade do escravo, fruto da carência de laços sociais que conformassem tanto uma vida familiar, como até mesmo cultural. Para aqueles que defendiam a noção de resistência escrava ${ }^{89}$, num mundo marcado por tantos arbítrios, houve escravos que superaram as adversidades com bravura e heroísmo. Ainda que esse movimento apenas invertesse os termos qualificativos do escravo - outrora submisso e passivo, agora herói e bravo - surgia pela primeira vez no Brasil uma incipiente idéia do escravo enquanto “agente histórico" 90 . E são escravos agentes de sua história, redefinidos não mais em moldes românticos, que surgem na historiografia paulatinamente a partir de meados de 1970, mas, sobretudo, 1980.

Esse novo paradigma se estabelecera a partir de um novo consenso historiográfico, marcado por uma revolucionária interpretação do paternalismo, empreendida por Eugene Genovese (em $1974^{91}$ ) e pela afirmação da existência e importância das famílias cativas na obra de Herbert Gutman (1976 ${ }^{92}$ ). Para ambos historiadores, “a cultura transmitida e reformulada entre as gerações, fornecia aos escravos recursos importantes para enfrentar e subverter as condições de seu cativeiro" 93 Escravos deixavam de ser, sob essa nova perspectiva, meros sobreviventes desse sistema autoritário; para se tornarem agentes cotidianos de sua história, imersos em laços familiares e culturais, aproveitavam-se das frinchas do sistema, sempre violento, para negociar sua condição escrava ou mesmo lutar contra ela. ${ }^{94}$

Esse partido teórico não implicava na crença da existência de relações harmoniosas entre escravo e senhor, mas sim, na consciência de que "ao lado da sempre presente violência, havia

\footnotetext{
${ }^{89}$ Entre eles estão Luiz Luna e José Alípio Goulart cujas obras foram citadas anteriormente.

${ }^{90}$ Lilia Moritz Schwarcz e Lúcia Garcia. Op. cit. 2006. p. 11 e 12.

${ }^{91}$ Eugene Genovese. Roll, Jordan, Roll: the world the slaves made. New York, Panteon Books, 1974. A versão em português chama-se A terra prometida: o mundo que os escravos criaram. Rio de Janeiro, Paz e Terra, 1988. v.I ( o volume II permanece inédito)

${ }^{92}$ Herbert G. Gutman. The Black Family in Slavery and Freedom, 1750-1925. New York, Random House, 1976.

${ }^{93}$ Robert Slenes. Op. cit. p. 39.

${ }^{94}$ Toda uma nova histografia tem sido feita sob essa perspectiva ainda que essas obras possuam inúmeras divergências entre si. Cito algumas: João José Reis. Rebelião Escrava no Brasil: a história do levante dos malês (1835). São Paulo, Companhia das Letras 2003. João José Reis e Eduardo Silva (org.) Negociação e Conflito: $a$ resistência negra no Brasil escravista. São Paulo, Companhia das Letras, 1999. Sidney Chalhoub. Visões da liberdade: uma história das últimas décadas da escravidão na corte. São Paulo, Companhia das Letras, 1990. Manolo Florentino, Paz nas Senzalas. Rio de Janeiro, Arquivo Nacional, 1995. Hebe Mattos de Castro. Das cores do
} 
um espaço social que se tecia tanto de barganhas como de conflitos. Essa abordagem que vê a escravidão, sobretudo, da perspectiva do escravo, um escravo real [sic], não reificado e nem mitificado, só muito recentemente vem ganhando corpo na historiografia brasileira.”95

Ainda que discorde da existência de um “escravo real”, o novo posicionamento teórico, manifesto (no Brasil) na análise de João José Reis e Eduardo Silva, permitiria tratar o escravo para além das categorias bipolares de “coisa”/“vítima” versus "herói”. Essa perspectiva, ao se utilizar desses conceitos (“vítima” e "herói”), como sendo os extremos de um gradiente dentro do qual os escravos se moviam, dá margem para que se possa pensar em uma gama ampla de possibilidades para o cativo, além da mera sobrevivência. “Os escravos não foram vítimas nem heróis o tempo todo, se situando na sua maioria e na maior parte do tempo numa zona de indefinição entre um e outro pólo. O escravo aparentemente acomodado e até submisso de um dia podia tornar-se o rebelde do dia seguinte, a depender da oportunidade e das circunstâncias". 96

Outro ponto significativo na análise de Silva e Reis são os nomes de figuras negras - na verdade, representações socialmente correntes - associados às categorias antitéticas de escravos “heróis” e “passivos”, respectivamente: Zumbi versus Pai-João/Mãe-Preta .

"A longa experiência colonial, no tocante às formas básicas de relacionamento, tem sido sintetizada através de uma dicotomia que permanece extremamente forte em nossa mentalidade coletiva. De um lado, Zumbi de Palmares, a ira sagrada, o treme-terra; de outro, Pai-J oão, a submissão conformada." 97

"Zumbi, Mãe-Preta e Pai-João, são apenas ênfases historiográficas. Concretamente, na história real [sic], cada cativo segundo um destino que muito raramente podia controlar - do eito, das minas, 'de servir', ao ganho, pajem ou capataz -, teria sua porção de ambos, maior ou menor, segundo cada caso, cada oportunidade. Na história, Pai-João não foi a ausência de luta, mas uma estratégia de luta sob condições extremamente desfavoráveis. 'A acomodação, em si mesma' como escreve Genovese, 'transpirava espírito crítico, disfarçava ações subversivas e freqüentemente confundia-se com seu aparente oposto - resistência'." 98

Essa dicotomia entre Zumbi e Pai-João/Mãe-Preta que, segundo Eduardo Silva, permanece muito forte em nossa mentalidade coletiva, re-afirma que tanto "Mãe-Preta” quanto

silêncio: os significados da liberdade no Sudeste escravista - Brasil século XIX. Rio de Janeiro, Nova Fronteira, 1998.

95 “Introdução” João José Reis e Eduardo Silva (org.) Op. cit. p.7.

${ }^{96}$ Idem. Aliás, Robert Slenes mostra que são os cativos mais “chegados” aos senhores que freqüentemente eram os líderes das revoltas nas senzalas. Robert Slenes. "Senhores e Subalternos no oeste paulista” in: Luiz Felipe de Alencastro (org.) História da vida privada no Brasil vol.2. São Paulo, Companhia das Letras. 1997/2002. p. 236 e 281.

${ }^{97}$ Eduardo Silva. “Entre Zumbi e Pai João, o escravo que negocia” in: João José Reis e Eduardo Silva (org.) Op. cit. p. 13. 
“Pai-João”99 são usualmente reconhecidos como escravos submissos, mansos, fiéis e vitimizados. Mas o autor, ao ter que discutir com essa imagem - nuançá-la - revela, também, como ela permaneceria ativa, não só no senso comum, mas inclusive na historiografia.

Eduardo Silva, na seqüência desse último trecho citado, identifica as origens de tais estereótipos historiográficos: “Tratávamos com imagens historiográficas, seja na linha da 'suave escravidão brasileira' que tem origem em Freyre, Tannenbaum, e Elkins; seja na linha revisionista, influenciada tanto por Marx quanto por Weber, empenhada - desde o final da década de 1950, mas sobretudo na década de 1960 - na busca de uma tradição revolucionária.”100 Mas tratando-se de "Mãe-Preta” e “Pai-João”, termos tão peculiarmente brasileiros, é de se imaginar que esse estereótipo da “doce escravidão”, cristalizado sob tais nomes, fosse reputado a Gilberto Freyre. Novamente, interligam-se metaforicamente imagens de uma escravidão mais amena, a figura da mãe-preta e Gilberto Freyre como autor dessa associação.

No entanto, na análise inaugurada por esses historiadores da geração de 1980, tanto “Mãe-Preta” quanto “Pai-João” não são meros cativos submissos, mas agentes de suas próprias histórias que negociam sua situação, ainda que submetidos à escravidão. A "Mãe-Preta”, sobretudo, fazia uso de sua "ascendência afetiva” e de sua intimidade cotidiana com os membros da família senhorial, para negociar sob esse regime hierárquico ${ }^{101}$. Aqui, pela primeira vez, dentre as análises citadas, a relação entre mãe-preta e filho branco é abordada integralmente, com toda sua ambigüidade. Afeto e violência são interdependentes tanto para as escravas - que têm acesso a favores senhoriais em função do amor que tecem pelo seu filho branco e que ele (criança) igualmente tece por ela -, como para o senhor que estimula o amor mais desinteressado da ama por seu filho, mediante o domínio da liberdade da escrava. Caso ele viesse a alforriá-la, seria um favor, em reconhecimento à fidelidade e ao amor que a escrava tinha pela família patriarcal. Luiz Felipe de Alencastro, com a mesma precisão cirúrgica do médico (Dr. Ferreira Pinto), “localiza a artéria que irriga o escravismo: aspirando sair de seu estatuto aviltante, 'seduzida e embalada' por essa esperança, a mucama deixaria de lado a sua ‘cria' para fornecer ao nhonhozinho todo o

\footnotetext{
${ }^{98}$ Eduardo Silva. "Fugas, revoltas e quilombos: os limites da negociação” in: João José Reis e Eduardo Silva (org.) Op. cit. p.78.

${ }^{99}$ Na próxima parte da dissertação trataremos da vinculação existente entre as representações da mãe-preta e de paijoão.

${ }^{100}$ Idem. Os autores citados em nota sobre linha revisionista são: Florestan Fernandes e Roger Bastide. Brancos $e$ Negros em São Paulo. São Paulo, Editora Nacional, 1971. Fernando Henrique Cardoso. Capitalismo e Escravidão. São Paulo, Difel, 1962. Otavio Ianni. As metamorfoses do escravo. São Paulo, Difel, 1962. Emilia Viotti da Costa. Da senzala à colônia. São Paulo, Difel, 1966. Para referência completa dos outros autores mencionados na citação vide bibliografia.

${ }^{101}$ Eduardo Silva. "Fugas, revoltas e quilombos: os limites da negociação” in: João José Reis e Eduardo Silva (org.) Op. cit. p.76.
} 
carinho que ele necessitasse. O arbítrio senhorial lograva extorquir da escrava um tipo especial de serviço que o simples salário não podia extorquir da ama-de-leite livre”. ${ }^{102}$

Seguindo essa perspectiva que faz da mãe-preta agente histórico, sua relação com o filho branco torna-se mais inteligível, sem entrar nas discussões qualificativas da escravidão, tal abordagem permite ver o paternalismo como o léxico de negociação entre senhores e escravos; léxico esse que envolvia sempre força e favor, perigos e prêmios. ${ }^{103}$

A ama-de-leite, escrava doméstica, estava intimamente envolvida nesse jogo. Por estar mais próxima da família senhorial, a escrava receberia alimentação e vestimentas diferenciadas, passaria a residir na casa da família e não mais na senzala, além de cultivar relações afetivas e favores do núcleo familiar senhorial, levando mesmo à expectativa de uma possível alforria. Graham comenta essas esperanças das amas: “as criadas pessoais - camareiras e amas-de-leite podiam aspirar ser recompensadas com afeição e confiança. No curso de seu trabalho, essas criadas atravessavam com freqüência os espaços da casa exclusivos aos membros da família e mantinham com estes um contato diário. Por meio da infinidade de pequenas atenções que prestavam aos patrões, podiam testemunhar de perto o lazer e a riqueza, que pertenciam a uma classe da qual elas, por serem pobres e serviçais, permaneceriam para sempre e de todo afastadas. Ainda assim, elas (...) se identificavam com as famílias às quais pertenciam. Ser uma mucama ou ama trazia recompensas tangíveis - entendidas como tais por ambos os lados - em retribuição por um serviço apreciado: podiam receber um atavio ou ornamento que significasse um status especial, (...) uma excursão ou, às vezes, até uma longa viagem (...) ou, talvez, um casamento com o escravo preferido do patrão. Por serem as mais privilegiadas entre as criadas, as mucamas [e amas], embora fossem escravas, podiam talvez esperar a alforria.”104

Nesse mundo permeado de afetos, favores, força e violência da escravidão, as amas-deleite teceram com os filhos da família branca, e mesmo com os pais desses filhos, uma relação íntima de troca afetiva; enunciada em inúmeras obras de literatura que analisarei. Mas essa relação não se constituía apenas de modo idílico; sua própria existência dependia da escravidão, ela era a condição dessa ligação afetiva que tanto marcou a infância brasileira, a ponto de ser evocada até os dias de hoje. O exemplo de doação extrema, de amor; o vínculo entre mãe-preta e filho branco só existiu mediante a separação de seus envolvidos em status hierárquicos distintos.

\footnotetext{
${ }^{102}$ Luiz Felipe de Alencastro. "Vida privada e ordem privada no Império” in: Luiz Felipe de Alencastro (org.) História da vida privada no Brasil vol.2. p. 66 e 67.

${ }^{103}$ Robert Slenes. "Senhores e Subalternos no oeste paulista" in: Luiz Felipe de Alencastro (org.) História da vida privada no Brasil vol.2. Op. cit.

${ }^{104}$ Sandra Lauderdale Graham. Proteção e Obediência. São Paulo, Companhia das Letras, 1992. p. 61.
} 
Nessa parte da dissertação, procurei mostrar como a representação da mãe-preta não constitui uma memória social qualquer. Surgida durante a escravidão, essa representação, do modo como foi incorporada por determinada intelectualidade brasileira, se mantém intimamente ligada a tal instituição. No entanto, os sentidos atribuídos a esta conexão - entre mãe-preta e escravidão - são muito diversos. Essa diversidade é resultado da própria ambigüidade desta representação, que abarca sentidos dessemelhantes. Pois, a mãe-preta tornou-se o símbolo tanto de uma “escravidão mais suave” - que possuía senhores severos, mas bondosos, e escravos fiéis , quanto do arbítrio escravocrata - que vetaria a possibilidade de relações sociais próprias aos escravos; entre as quais se encaixava a maternidade escrava.

Contudo, mais recentemente, a partir da década de 1980, a mãe-preta, em sua associação com a escravidão, vem sendo interpretada de uma nova maneira: ela deixa de ser apenas vítima, tornando-se um agente histórico que atuava sob o arbítrio da escravidão. Mas a escravidão tampouco, nessa mesma linha de pensamento, continua a ser a mesma; ela não é mais adjetivada por qualificativos como "suave” ou “cruel”. A instituição passa a ser entendida como fundada na força e no arbítrio, mas tendo o "paternalismo" como léxico. E, justamente, nessa frincha entre escravidão e paternalismo, a mãe-preta agia historicamente, fazendo uso de sua ascendência afetiva pela família branca.

Suponho, assim, que a "versatilidade” da representação da mãe-preta é resultado da ambigüidade fundante da sua figura, que mescla afeto e proximidade, com hierarquia e diferença. No entanto, quando me dedico a estudar as representações da mãe-preta não busco esclarecer o modo de funcionamento da instituição escravista no Brasil e, nem mesmo, as condições de vida das amas-de-leite escravas. Na verdade, meu objetivo é entender como essa figura comporta uma memória no pós-abolição que reverbera até os dias de hoje. No limite, tenho como propósito analisar os sentidos que a mãe-preta permite veicular.

Diante desse quadro, minha posição - como intérprete e antropóloga - implica em "levar a sério” os discursos sobre a mãe-preta e, por meio deles, dar inteligibilidade às práticas sociais que a envolvem. Nessa medida, em minha análise, a ambigüidade da representação da mãe-preta não é desconstruída e, tampouco, tomada como decorrência de qualquer contexto específico; ela constitui o ponto de partida que constrói inúmeros discursos sobre esta figura. Não se pretende, também, supor que não existam diferenças e hierarquias, ao contrário, tal suposição é ponto de partida. 
Analisarei, portanto, alguns desses discursos; mais especificamente, os daqueles "literatos” que constroem a figura da mãe-preta em suas obras, publicadas entre os anos de 1880 e 1950. Nessa pesquisa, tais agentes funcionam como uma espécie de "nativos", pois fornecem versões sobre a mãe-preta.

Interessa-me, em particular, os sentidos que os "literatos/nativos" deram à mãe-preta. Tendo como ponto de partida as formulações feitas por eles, perscruto a memória edificada em torno dessa figura. Portanto, é por meio de um “corpo a corpo” com a literatura que realizo meu trabalho antropológico. Numa antropologia definida como ciência social do observado ${ }^{105}$, analiso os significados agenciados pelos literatos para construir (e reelaborar) a figura da mãe-preta.

Nesse contexto histórico-cultural (1880-1950), quando os literatos/agentes culturais realizavam um movimento de construção, logo re-construção, da memória em torno da mãe-preta - selecionando experiências e personagens da escravidão - eles não “inventaram uma tradição"106, tal como o termo fora definido por Eric Hobsbawn. Segundo esse historiador, há “tradições inventadas” que se contrapõem a "tradições genuínas”; de modo que o termo invenção é utilizado no sentido de falseamento (quase ideológico), na acepção de ato de criação de uma obra inautêntica.

No entanto, toda tradição - assim como toda cultura, ou mesmo, toda memória - é “inventada”. Mas “invenção” aqui, tem o sentido de “imaginação”, de “criação”, de “experimentação original” de sentidos culturais pré-estabelecidos. Para Roy Wagner a própria antropologia como disciplina depende da "invenção" da cultura: “anthropology is the study of man 'as if' there were culture. It is brought into being by the invention of culture, both in the general sense, as a concept, and in the specific sense, through the invention of particular cultures”. 107 Para Maurice Halbwachs, a própria memória coletiva implicava em seleção e em "invenção": alguns poucos fatos lembrados eram re-articulados entre si, numa espécie de invenção de conexões e lógica ${ }^{108}$.

Os literatos que estudo, por conseguinte, “inventaram” uma memória que era influenciada (mas não determinada) pelo contexto (1880-1950) em que realizaram essa rememoração literária. Cabe-me agora ficar atenta aos modos como se deu a rememoração da figura da mãe-preta - se traz a ambigüidade de um afeto surgido mediante a escravidão, se qualifica uma especificidade da

\footnotetext{
${ }^{105}$ Essa definição de Antropologia é de Claude Lévi-Strauss e está expressa em: Claude Lévi-Strauss. Antropologia Estrutural. Rio de Janeiro, Tempo Brasileiro, 1975. p. 404.

${ }^{106}$ Eric Hobsbawm e Terence Ranger. A Invenção das Tradições. São Paulo, Paz e Terra, 1997/2002.

${ }^{107}$ Roy Wagner. The Invention of Culture. Chicago, University os Chicago Press, 1981. p. 10.

${ }^{108}$ Maurice Halbwachs. A Memória Coletiva. São Paulo, Vértice, 1990.
} 
escravidão brasileira, ou mesmo, se remete-se, impreterivelmente, ao universo da escravidão etc. Atentarei, nessa medida, para os sentidos comunicados por meio das representações da mãe-preta na literatura desse período. Somente por esse viés é possível descobrir por quais caminhos essas representações se tornaram re-incidentes e, de alguma maneira, mutáveis entre 1880 e 1950.

Mas, antes deste empreendimento interpretativo, convém refletir um pouco mais sobre esses “literatos/nativos” e sua literatura, que produziram uma memória da mãe-preta. 


\section{CAPÍtULO 2}

\section{Versões brancas da mãe-preta}

\section{A heterogeneidade do material}

As fontes literárias que construíram essas múltiplas representações da mãe-preta são muito heterogêneas. Foram produzidas em contextos históricos muito diversos, além de integrarem movimentos literários diferentes. Quanto à forma, elas tampouco se parecem. Só para se ter uma primeira idéia, trabalharei com poesia e prosa e, dentro dessa última categoria, há contos, romances e literatura infantil.

Entre os autores, existem os que são famosos e reconhecidos pela crítica nacional, e aqueles que foram publicados em diversas línguas, tais como: Joaquim Nabuco, Olavo Bilac, Monteiro Lobato, Cassiano Ricardo, Jorge de Lima e José Lins do Rego. Há também escritores reconhecidos, mas cuja obra não foi tão explorada, entre eles destaco: Mello Moraes Filho, Augusto dos Anjos, Raul Bopp, Luís Jardim, Viriato Corrêa. Outros são, literalmente, ilustres desconhecidos, que tiveram muita relevância em sua época ou região, mas que não mantiveram seus nomes junto à história da literatura mais canônica: Luiz Delfino dos Santos, Luiz Demétrio Juvenal Tavares, Cornélio Pires, Cyro Costa, Murillo Araújo, Oswaldo Orico, Ofélia e Narbal Fontes. Estão incluídas nas fontes, ainda, figuras mais “obscuras”, cujos dados biográficos são até mesmo difíceis de serem encontrados, mas que do mesmo modo escreveram sobre as mãespretas; destaco os nomes de: Maria Alves Velloso, Wilson W. Rodrigues e Antonieta Borges Alves.

Em meio a esse mar heterogêneo fica cada vez mais perceptível como o crivo para a seleção dessas obras foi, meramente, a presença de representações da mãe-preta. Nesse recorte temático da documentação, acabei por trabalhar com um largo intervalo de tempo que tem como marcos 1881 - 1954. Essa aparente falta de critério visa, no entanto, explorar a variedade de representações que a mãe-preta evoca ao longo do tempo, sobretudo, a partir do momento de desmontagem da escravidão.

Diferentes ênfases representativas em alguns momentos podem, e serão, explicadas em função de tendências culturais e literárias da época. Porém, junto a essa análise mais circunstanciada, procurarei, igualmente, expor características e tendências estruturais presentes nas diferentes versões das mães-pretas nesse dilatado intervalo de tempo. 
Mas antes de começar a refletir sobre os filtros que os diferentes movimentos históricoliterários construíram para a composição de sua obra, convém ponderar sobre os autores dessa literatura que fazem referências às mães-pretas.

Escrever entre finais do Segundo Reinado e início da República era um privilégio de poucos, de modo que é uma elite intelectual - majoritariamente branca - a qual inicia a produção dessas representações. Nessa medida, as versões literárias da mãe-preta não são autorepresentações, mas sim construções de uma elite letrada, branca e eminentemente masculina. Ou seja, trata-se do mesmo segmento social que num passado muito recente fora camada senhorial, e que possuía escravos.

Daí o maior viés inerente às fontes utilizadas: elas são representações dos brancos sobre os negros. Tratam dos negros, escravos ou ex-escravos, em suas relações com os brancos e sua família. Há, portanto, uma ausência de relações dos negros entre si mesmos. Por esta razão, não desconsidero as relações hierárquicas estabelecidas: elas são o ponto de partida, mas não de chegada.

É esse jogo de projeções dos brancos sobre as negras (no caso específico da mãe-preta) que aparece nos textos. E por esse fator de dissociação social se explicam, em parte, o exotismo e o sentimentalismo piedoso presentes em alguns desses escritos ${ }^{109}$. O primeiro só era possível mediante uma separação - uma visão externa - que supõe um afastamento social entre classes produtoras (branca) e objeto (negros) de literatura. O segundo revela um "branco consciente”, que luta pela libertação dos “negros brutalmente explorados” ou, ainda, evoca experiências pessoais com a escravidão, e até mesmo uma certa "memória poética” da convivência com as escravas domésticas.

Ciente desses limites existentes para a produção de representações da mãe-preta, não trato essas imagens apenas como meros produtos dessas relações sociais de classe. Elas constituem-se igualmente enquanto símbolos que guiam essas relações; são, portanto, produtoras da realidade social. Ainda que se tratem de representações dos brancos sobre os negros, são essas mesmas representações que guiam, muitas vezes, a ação dos brancos perante os negros. E é em relação a essa representação esperada que os negros interagem socialmente. ${ }^{110}$

Desse modo, tendo em mente essa ambigüidade própria das representações artísticas, é que tomo essas fontes como também reveladoras de outras (ou seriam as mesmas) ambigüidades:

109 Exotismo e sentimentalismo também são, em parte, explicáveis pela mediação dos diferentes movimentos literários, os quais também, por serem históricos, estão limitados pela contingência das relações sociais. 
de um verdadeiro afeto trocado entre nhonhozinho e ama; de uma significante interpenetração de culturas, mas permanecendo consciente de que essa troca nunca se processou entre iguais.

\section{O negro e a mãe-preta na literatura brasileira}

A literatura não é tomada aqui apenas como mero epifenômeno ideológico, mas como um dos meios através dos quais se constroem relações e, inclusive, nações. Assim, é sintomático que simultaneamente ao movimento brasileiro de independência política, inicia-se um processo de “independência literária”, bastante evidente no nacionalismo romântico que, por meio do indigenismo, começa uma afirmação de nossa personalidade nacional - peculiar em função do meio, das raças e da história - diante da regra européia ${ }^{111}$.

Mas não só o índio constitui nossa "peculiaridade racial”: o negro, que com seu trabalho sustentava o Império, também será aos poucos incluído nesta afirmação literária; e ainda no romantismo, ele terá papel de destaque.

Segundo Roger Bastide, a poesia do século XIX trará a figura do negro dos gêneros baixos "aos gêneros elevados, e isso constituirá uma nova incorporação ao tesouro poético, uma espécie de ascensão literária vinculada à ascensão social dos mulatos e dos negros livres, um primeiro triunfo da causa de Pai João”. ${ }^{112}$ Dessa maneira, a inclusão da temática do negro nos principais gêneros da literatura ocorre durante o romantismo, mais especificamente em sua terceira fase: a condoreira, encabeçada por Castro Alves. Mas essa elevação literária do negro tem paralelos na estrutura social: a promoção do mulato numa sociedade ainda marcada pelo antagonismo entre brancos e negros. Antonio Candido também pondera sobre essa anexação tardia do negro à literatura nacional, que tinha como limites a estrutura social: "o negro, escravizado, misturado à vida quotidiana em posição de inferioridade, não se podia facilmente elevar a objeto estético, numa literatura ligada ideologicamente a uma estrutura de castas. Ressalvados um ou outro poema lírico, podemos dizer que foi como problema social que surgiu primeiro à consciência literária (...). ${ }^{113}$

\footnotetext{
${ }^{110}$ Sobre o caráter indissociável da relação entre representação e prática social consultar: Eunice Durham. "Cultura e Ideologia” in: A Dinâmica da Cultura. São Paulo, Cosac \& Naify, 1984/2004.

${ }^{111}$ Antonio Candido. "Literatura e cultura de 1900 a 1945" in: Literatura e Sociedade. São Paulo, Publifolha, 1965/2000. Mais especificamente sobre o indigenismo e a construção da nação vide: Lilia Moritz Schwarcz. As Barbas do Imperador. São Paulo, Companhia das Letras, 2000; especialmente capítulo 7.

${ }^{112}$ Roger Bastide. “A incorporação da poesia africana à poesia brasileira”. In: Poetas do Brasil. São Paulo, Edusp, 1946/ 1997. p. 22.

113 Antonio Candido. Formação da Literatura Brasileira. São Paulo/ Belo Horizonte, Edusp/Editora Itatiaia, 1957/1975. p. 274 e 275.
} 
Esse problema social só começa a ser anunciado publicamente com a crise de um Brasil rural, simultânea ao crescimento de uma cultura urbana e com os avanços do movimento abolicionista em meados de 1870. Foi desse modo que, na terceira fase romântica, muito influenciada por Victor Hugo ("satirizador de tiranos e profeta de um mundo novo" 114), numa generalização do sentimento humanitário ao negro - ou melhor, ao escravo -, que este último começa a ser o principal objeto da poesia.

Roger Bastide mostra ainda em seu ensaio “A incorporação da poesia africana à poesia brasileira” (o qual me serve como guia), que anteriormente à fase hugoana - de luta pela libertação do escravo e da humanidade - o negro surgiu na sensibilidade romântica marcado pela influência de Lamartine, quando se enalteceu a brandura e a doçura africanas. Convidava-se ${ }^{115}$, então, a uma efusão sentimental com o escravo “doce, sofredor e resignado”. Mas essa aproximação afetiva com o escravo era limitada pelas barreiras sociais (e também raciais), de modo que foi preciso a passagem de um romantismo sentimental (lamartiniano) a um romantismo social (hugoano), para que surgisse efetivamente uma poesia do escravo. "Em vão procurarão unir-se os corações, as instituições sociais são bastante fortes para impedir a comunhão, o social é mais poderoso do que a boa vontade e que os sentimentos individuais; é preciso então voltar-se, daí para a frente, contra o social e fazer uma poesia revolucionária.”116 É só com o combate efetivo à escravidão que o negro vira centro da vida lírica no papel de herói, de amante e, no limite, de ser humano.

Nesse momento literário é que surgem as primeiras representações das mães-pretas ou, no caso, “mães escravas”, na poesia de Mello Moraes Filho. O autor nascido em 1844, na cidade de Salvador, Bahia, teve dificuldades para concluir os estudos em função da falência do pai. Ingressou num seminário e em 1867 voltou à cidade natal para ordenar-se padre. Nesse momento, travou contato com a então efervescente poesia abolicionista, conhecendo aquele que seria seu mestre, Castro Alves. Retornou depois ao Rio de Janeiro, onde começou a viver, com dificuldades, de literatura e jornalismo ${ }^{117}$. Seu livro Cantos do Equador ${ }^{118}$ possui, na terceira parte - "Poemas da Escravidão” -, inúmeras poesias sobre mães-escravas, amas-de-leite e mães de criação. Os poemas têm um texto descritivo, permeado de muitas denúncias dos castigos e

\footnotetext{
${ }^{114}$ Alfredo Bosi. História concisa da literatura brasileira. São Paulo, Cultrix, 1994. p. 120.

115 Entre os autores influenciados por Lamartine, citados por Bastide, estão João Guilherme Ratcliff e José Joaquim Correia de Almeida. Já Bittencourt Sampaio faria a transição entre os romantismos “sentimental” e "social”. Roger Bastide. Op. cit. p. $23-27$.

${ }^{116}$ Idem. p. 27.

117 Foi nesta mesma cidade que Mello Moraes faleceu em 1919. Dados biográficos extraídos de: Raimundo de Menezes. Dicionário literário brasileiro. Rio de Janeiro, LTC, 1978. p. 461 e 462.
} 
sofrimentos a que eram submetidos os escravos. O poeta, em algumas ocasiões, reage liricamente diante da violência impingida ao objeto de sua descrição. As antíteses de influência hugoana são abundantes como notou, novamente, Roger Bastide: “o Brasil Imperial era a realização concreta daquilo que não passava de um processo poético para Hugo. A estratificação da sociedade em duas classes opostas e contrárias, os brancos e os negros, os senhores e os escravos, contraste de cores e de posição social ao mesmo tempo, não seria a própria antítese hugoana? Bastava acrescentar aí que o amo tinha a alma cruel de um selvagem, ao passo que o escravo (...) tinha a alma de um grão-senhor!”119

Como é comum nos autores desse grupo, Mello Moraes faz, por meio de sua poesia, uma espécie de “diagnóstico social” detendo-se, sobretudo, na categoria social "escravo”, e não nos negros em particular. É, contudo, até mais sentimental que Castro Alves; e em função de seu interesse nos (então) novos estudos folclóricos, faz descrições pormenorizadas, aproximando-se um pouco mais da poesia afro-brasileira. ${ }^{120}$

Outro escritor romântico que compôs poesias que falavam sobre amas negras foi Luiz Delfino dos Santos ${ }^{121}$. Nascido em 1834, na cidade de Desterro em Santa Catarina, o autor cresceu circundado e cuidado por escravos domésticos, como revelou o organizador de sua obra completa, Lauro Junkes: “cresceu na liberdade de criança, ainda muito cercado pela natureza, cuidado por diversas amas e escravos - Ana, Teresa, Pai João... pessoas dóceis e resignadas em sua condição servil, que o poeta, mais tarde, cantou em sonetos." ${ }^{122}$ É fato que na poesia desse autor, os cativos surgem somente como passivos e dóceis, conforme analisarei mais adiante; no entanto, é digno de nota que o autor faça uso de suas experiências infantis com a escravaria doméstica para compor sua obra lírica, reconhecida pela vastidão e plasticidade.

Luiz Delfino, aos dezessete anos, mudou-se para o Rio de Janeiro, onde se formou em Medicina. Exerceu a profissão de médico paralelamente à sua produção poética, até o fim da vida, em 1910. Delfino nunca publicou um livro enquanto viveu. Sua obra foi divulgada apenas por meio da imprensa. Por essa razão, imagina-se que esse poeta, reconhecido e lido por seus contemporâneos, não tenha integrado a Academia Brasileira de Letras, para a qual havia sido cogitado quando de sua fundação. Reputa-se igualmente à dispersão de sua obra, a ausência do autor nas antologias poéticas referidas tanto ao romantismo hugoano, como ao parnasianismo.

\footnotetext{
${ }_{118}^{118}$ Alexandre José de Mello Moraes Filho. Cantos do Equador. Rio de Janeiro, Garnier Livreiro-Editor, 1881/ 1900.

${ }^{119}$ Roger Bastide. Op. cit. p. 28.

${ }^{120}$ Idem. p. 31.

${ }^{121}$ Também conhecido apenas por “Luis Delfino”.
} 
O autor foi até mesmo considerado por Ronald de Carvalho "um dos melhores discípulos do lirismo hugoano, entre nós. Para isso nada lhe falta: nem o verbalismo, nem a exaltação, por vezes gongórica, do estro"123. Segundo revelam as fontes, o poeta apoiava o movimento abolicionista desde 1880, “e a 18 de maio de 1888, Delfino figurou entre destacados expoentes abolicionistas, em matineé literária realizada no Teatro Recreio Dramático, para saudar a Lei Áurea, quando entre poemas de autores vários, foi apresentado o [seu] 'Fiat Libertas' ”. ${ }^{124} \mathrm{O}$ verbalismo mencionado pelo crítico se fez presente em muitos de seus poemas longos - como o composto a propósito da Lei Áurea -, ou ainda em “A Nação”, quando homenageia a abolição da escravidão no Ceará. A exaltação se faz por meio de metáforas grandiloqüentes: com um protesto contra a tirania e uma apologia da liberdade.

Mas, quando o poeta escreveu poesias que remetiam à sua infância entre "escravos queridos”, o tom era mais sentimental do que aquele presente em seus textos condoreiros. Nessa medida, ao evocar “amas e pajens doces e saudosos”, ele se afastava dos "laivos hugoanos”, e se aproximava do romantismo de Lamartine, evidenciando uma valorização da humanidade afetiva do escravo.

Mas o romantismo social - que estende a humanidade e a liberdade ao escravo, numa retórica que faz dele herói - mantém, contudo, certas limitações próprias à época. “Um golpe de vista, mesmo rápido, nas obras que [o romantismo] originou, mostra todavia as resistências que o processo encontrava, não apenas no público, mas no próprio escritor. Enquanto se tratava de cantar as mães-pretas, os fiéis pais-joões, as crioulinhas peraltas, ia tudo bem; mas na hora do amor e do heroísmo o ímpeto procurava acomodar-se às representações do preconceito. Assim, os protagonistas de romances e poemas, quando escravos, são ordinariamente mulatos, a fim de que o autor possa dar-lhes traços brancos e, deste modo, encaixá-los nos padrões da sensibilidade branca.”125 Segundo Antonio Candido, essa poesia consegue, enaltecendo a humanidade desses “escravos fiéis”, denunciar a violência e o sofrimento a que mãe-preta e pai-joão estavam submetidos. Tal atitude é aceitável tanto para o autor como para o público, que os vê como escravos bondosos, amorosos e merecedores dessa piedade humanística, assim como da liberdade. Os leitores poderiam, até mesmo, reconhecer em suas próprias experiências pessoais, escravos domésticos semelhantemente afetuosos. Mas quando se tratava de fazer dos escravos

\footnotetext{
122 Lauro Junkes. “Luiz Delfino: esboço biográfico” in: Luiz Delfino. Poesia Completa: sonetos, tomo I. Florianópolis, Academia Catarinense de Letras, 2001. p. 28.

${ }^{123}$ Ronald de Carvalho apud Raimundo de Menezes. Dicionário literário brasileiro. Op. cit. p. 230 e 231. Alguns dos dados biográficos também foram retirados do mesmo verbete.

${ }^{124}$ Lauro Junkes. “Luiz Delfino: esboço biográfico”. Op.cit. p. 35.
} 
heróis ou pares românticos, era necessário misturá-los ao branco - “amulatá-los” ou mestiçá-los de modo a torná-los verossímeis nesses papéis literários, ocupados ordinariamente pelos brancos, e que não cabiam a um negro "puro”. Portanto, o que Candido defende é que o preconceito vigente na época permite ao romantismo valorizar a humanidade, defender a liberdade, mas somente dos negros tipicamente conhecidos como escravos. No entanto, quando tal postura implica em reconhecê-los como agentes de sua própria liberdade, ou como promotores de laços amorosos $^{126}$ - papéis sociais que não se associam aos negros - sua valorização só é possível mediante um “branqueamento” literário.

Bastide também vê outros limites nessa “poesia do escravo”, feita pelos românticos: “o branco (...) preocupado com a questão social, predominante na pesquisa folclórica, não tinha tempo nem mesmo a idéia de ir além do social ou da pintura externa; quando ele assistia às festas e aos cantos dos escravos, ficava obcecado pelos preconceitos da inferioridade cultural, passava à frente sem procurar deixar-se embebedar por uma música muito estranha ainda para seus ouvidos. Será preciso o 13 de maio para que a incorporação total da poesia africana à poesia brasileira se torne possível”. ${ }^{127}$ Os românticos manteriam certo distanciamento diante das manifestações culturais africanas ou afro-brasileiras; o preconceito e a escravidão vigentes não permitiriam outra posição, senão a de externalidade entre o poeta e seu objeto lírico.

Curiosamente, finda a escravidão, o movimento poético que lhe foi quase contemporâneo - o parnasianismo - manteve, ou mesmo acentuou, esse afastamento diante dos negros. Aqueles “arroubos de sentimentos inflamados”, ou a reação do poeta diante da descrição do sofrimento do escravo, “somem” nessa fase. “O Parnaso é uma reação contra a poesia subjetiva, contra a expressão da vida interior”. Para um poeta parnasiano haveria apenas a vida exterior, de modo que a ênfase lírica se dá sob a forma descritiva por excelência. ${ }^{128} \mathrm{O}$ afastamento entre poeta e objeto lírico era, portanto, um pressuposto para a realização dessa descrição detalhada e externa.

O grupo parnasiano pregava ainda um gosto pela “descrição nítida (a mimese pela mimese), concepções tradicionalistas sobre o metro, ritmo e rima e, no fundo, o ideal da impessoalidade que partilhavam com os realistas do tempo”. ${ }^{129}$ Essa preocupação academicista com a métrica está presente em suas poesias, que tendem “seja para a epopéia, que é uma história dos comportamentos, uma série de gestos, de atos externos, objetivos, seja para a descrição e em

\footnotetext{
${ }^{125}$ Antonio Candido. Op. cit. 1957/1975. p. 275.

${ }^{126}$ À exceção de sua relação afetuosa com as crianças brancas, já que esse era o papel social comum às figuras de mãe-preta e pai-joão.

${ }^{127}$ Roger Bastide. Op. cit. p. 34 e 35.

${ }^{128}$ Idem. p. 36.
} 
particular a descrição da natureza, ainda que estranha a nossas afeições”. ${ }^{130}$ A forma lírica serve, portanto, à expressão dessa externalidade descritiva parnasiana, que também trata do negro dessa maneira.

Nesse momento, o negro deixará de ser visto como humano para tornar-se uma espécie de "escultura”, ou mesmo estátua, feita de bronze, para ser contraposta àquela de mármore que representaria os brancos. O negro, enquanto objeto poético, é tomado por sua aparência exterior, sua beleza formal e corporal. ${ }^{131}$ Roger Bastide até mesmo descreve os poemas parnasianos de Cyro Costa - “Mãe Preta” e "Pai João” -, como sendo "baixos-relevos”, ou seja, um tipo específico de escultura. Esse poeta, cujos sonetos mais conhecidos são justamente “Mãe Preta” e “Pai João”, nasceu em 1879 na cidade de Limeira. Seguiu carreira bacharelesca, formando-se em Direito. Seus primeiros versos são publicados em 1900 no Diário Popular. Foi inclusive por meio dos jornais que divulgou sua obra poética compilada postumamente em Terra Promettida $^{132}$, a qual veio a público um ano após seu falecimento, em 1937. O autor, junto com os colegas do movimento parnasiano - Olavo Bilac ${ }^{133}$, Martins Fontes, Goulart de Andrade, Aníbal Teófilo e outros - fundou a Sociedade dos Homens de Letras do Brasil. ${ }^{134}$

O parnasianismo legou para seus contemporâneos simbolistas a paixão pelo efeito estético. No entanto, esses dois movimentos contrapunham-se pela ênfase na subjetividade. O simbolismo, em função do papel de destaque que dava ao subjetivismo, serviu até mesmo de núcleo para manifestações espiritualistas ${ }^{135}$. Augusto dos Anjos explora ao limite essa dimensão do "eu” poético, extremamente pessimista, e sua relação com o Cosmos. Contudo, para tal, faz uso de um vocabulário científico, tomado de empréstimo ao evolucionismo. Segundo Candido, “a embriaguez da terminologia científica, a visão materialista de carne corrupta e as taras fisiológicas, são a derradeira manifestação daquele sentimento romântico da morte, que vem abalar a pletora verbal dos últimos e vacilantes condores”. ${ }^{136}$

Esse pessimismo subjetivo também está presente em um poema do autor - "Ricordanza della mia Gioventu” -, em que ele se lembra de sua ama-de-leite da infância, o qual pode ser

\footnotetext{
${ }^{129}$ Alfredo Bosi. Op. cit. p. 219 e 220.

${ }^{130}$ Roger Bastide. Op. cit. p. 36.

131 Idem.

132 Cyro Costa. Terra Promettida. Rio de Janeiro, José Olympio Editora, 1938.

133 Esse importante poeta parnasiano também produziu um texto que traz a representação da mãe-preta, mas trata-se de uma obra de literatura infantil, cuja análise será feita mais adiante.

${ }^{134}$ Dados biográficos retirados de Luis Correia de Melo. Dicionário de Autores Paulistas. São Paulo, 1954. p. 164.

135 Antonio Candido. Op. cit. 1965/2000. p. 105.

${ }^{136}$ Antonio Candido. Op. cit. 1957/1975. p. 290.
} 
encontrado no único volume de suas poesias publicado em vida: $E u{ }^{137}$ O poeta nasceu em 1884 , no município de Pau D’Arco, Paraíba, e, desde o Secundário, apresentava problemas de saúde, sofrendo de tuberculose. Formou-se advogado, mas nunca exerceu a profissão, sobrevivendo do ensino de Língua Portuguesa, primeiro no seu Estado natal, depois no Rio de Janeiro, para onde se mudou em 1910. Morreu em 1914, na cidade de Leolpodina, Minas Gerais, para onde se mudara em busca de um melhor clima para viver. ${ }^{138}$

Bastide não comenta quase nada sobre a presença do negro no simbolismo. Diz apenas que ao adotarem o verso livre, os simbolistas permitiram que a principal força da poesia africana - o ritmo - reencontrasse sua autonomia fora das estruturas tradicionais. "Para que a poesia da África floresça no Brasil, será preciso, portanto, que o simbolismo venha quebrar previamente, as normas parnasianas". 139

Outro movimento que também permeia o intervalo entre os anos de 1900-1922 na vida literária brasileira é o regionalismo, principalmente em prosa; sob a forma “conto sertanejo”, alcançou uma voga surpreendente. O realce dado ao típico ou ao regional era de longa data uma das vias pelas quais a literatura afirmava nossa "personalidade peculiar”. Esse verso sertanista, meio popular e meio culto, teve em Catulo da Paixão e Cornélio Pires seus principais representantes. ${ }^{140}$ Esse último autor, nascido em 1884, na cidade de Tietê, ficou reconhecido pelos seus contos de “caboclos”, em que reproduzia o linguajar típico caipira. Ele começou sua vida literária sendo, primeiramente, tipógrafo, depois trabalhando como caixeiro-viajante. Teria desenvolvido ainda pesquisas folclóricas, domínio que se expressaria no preciosismo com que reproduz a fala dos caboclos: sua pronúncia, jeito e atitudes. Cornélio Pires migrou para São Paulo e, além de trabalhar em diversos jornais, travou conhecimento com o grupo “Cenáculo” integrado por Monteiro Lobato e Godofredo Rangel, entre outros. Em 1910, publicou sua primeira obra A musa caipira e, em 1915, Quem conta um conto e outros contos (coisas de outrora) ${ }^{141}$, que traz dois contos em que figuram mães-pretas. O autor tornou-se bastante conhecido, e teve muito sucesso devido a essa "revelação" do Brasil caboclo composto pelos caipiras, entre os quais se encontra “o caipira negro”, descrito da seguinte maneira: “caipiras pretos são os descendentes dos africanos já desaparecidos do Brasil. (...) Almas carinhosas e pacientes, generosas e humildes são os 'negros velhos'. (...) É trabalhador e não se deixa pisar

\footnotetext{
137 Augusto dos Anjos. “Eu” in: Toda Poesia. Rio de Janeiro, Paz e Terra, 1912/1978.

${ }^{138}$ Biografia retirada de Alfredo Bosi. Op. cit. p. 288.

139 Roger Bastide. Op. cit. p. 36.

${ }^{140}$ Alfredo Bosi. Op. cit. p. 333.
} 
pelos brancos - que muito estima e respeita - mas, por 'qualquer-cousa' responde logo: - 'Sinhô me descurpe... mais tempo de escravo já cabô!’ „142

Antonio Candido tem, no entanto, muitas reservas a esse movimento literário, que ele considera exotizante de nossas próprias características: "Gênero artificial e pretensioso, criando um sentimento subalterno e fácil de condescendência em relação ao próprio país, a pretexto de amor da terra, ilustra bem a posição dessa fase que procurava, na sua vocação cosmopolita, um meio de encarar com olhos europeus as nossas realidades mais típicas. Forneceu-lho o 'conto sertanejo', que tratou o homem-rural do ângulo pitoresco, sentimental e jocoso, favorecendo a seu respeito idéias-feitas perigosas tanto do ponto de vista social quanto, sobretudo, estético”. ${ }^{143}$ O regionalismo do conto sertanejo, segundo o crítico, teria resolvido mal a dialética entre localismo e cosmopolitismo que rege nossa vida espiritual. Adotara o ponto de vista cosmopolita - estrangeiro - para falar do local, de modo a tratar como pitoresco aquilo que nos seria peculiar e cotidiano. Esse afastamento "forjado” do escritor nativo para descrever o (também) nativo caboclo leva a um certo sentimentalismo, e à repetição de fórmulas estéticas, sobretudo uma relativa idealização que já fora impingida ao índio e ao escravo durante o romantismo.

Esse alheamento diante daquilo que nos é original só foi rompido no modernismo, que inaugurou uma nova “dialética do universal e do particular, inscrevendo-se neste com força e até arrogância, por meio de armas tomadas a princípio do arsenal daquele”. ${ }^{144}$ É um mergulho profundo no particular, uma fusão que terá resultados evidentes na maneira com que nossas peculiaridades de formação étnica são tratadas.

Mais uma vez, recorro às palavras de Candido; “na nossa cultura há uma ambigüidade fundamental: a de sermos um povo latino, de herança cultural européia, mas etnicamente mestiço, situado no trópico, influenciado por culturas primitivas, ameríndias e africanas. Esta ambigüidade deu sempre às afirmações particularistas um tom de constrangimento, que geralmente se resolvia pela idealização. Assim, o índio era europeizado nas virtudes e costumes (processo tanto mais fácil quanto desde o século XVIII os nossos centros intelectuais não o conheciam mais diretamente); a mestiçagem era ignorada; a paisagem amaneirada. No período de 1900-1920, vimos que o caboclo passou por um processo de idealização (...). O Modernismo rompe com este estado de coisas. As nossas deficiências, supostas ou reais, são reinterpretadas

\footnotetext{
${ }^{141}$ Cornélio Pires. Quem conta um conto... E outros contos (coisas de outrora). São Paulo, Livraria Liberdade, 1915/1943.

${ }^{142}$ Cornélio Pires. Conversas ao pé do fogo (páginas regionaes). São Paulo, Graphico-Editora Monteiro Lobato, 1921/ 1924.

${ }^{143}$ Antonio Candido. Op. cit. 1965/2000. p. 105.
} 
como superioridades. (...) Atribuiu[-se] um significado construtivo, heróico, ao cadinho da raças e culturas localizado numa natureza áspera. (...) O mulato e o negro são definitivamente incorporados como temas de estudo, inspiração, exemplo. O primitivismo é agora fonte de beleza e não mais empecilho à elaboração da cultura. Isso, na literatura, na pintura, na música, nas ciências do homem”. 145

É a partir deste “desrecalque” de nossa composição racial mestiça, recentemente positivada de modo desavergonhado, que se pode entender a ascensão literária definitiva do negro, não apenas como objeto de lirismo dos brancos, mas como fonte de inspiração para uma nova lírica. Esse é justamente o movimento “primitivista”, que recolhe nesse “outro” - o negro interno ao país, a inspiração e, até mesmo, uma nova forma de se fazer poesia. Roger Bastide também observou esse movimento: "resta a única solução de procurar o exotismo no interior da terra exótica, um exotismo de segundo grau. É exatamente o que os poetas vão buscar, antes de mais nada, nos temas brasileiros: uma visão da África, uma sensação de dépaysement."146 Para Bastide, esse processo leva à consolidação de uma poesia inédita: a poesia afro-brasileira. Esta supera a fase do exotismo, o qual pressupunha uma separação entre escritor e objeto lírico; misturando-se a ele, perdendo-se nele. Surge então uma poesia que incorpora um ritmo, característico da lírica africana: "tais sentimentos (...) exprimem-se em sua originalidade poética, e não como na antiga poesia, através de uma tradução de negro em branco; escapa assim a todas as perversões a artificialismos que lhe eram impostos pela aplicação das antigas artes poéticas. Chegamos ao momento da incorporação verdadeira, o momento da África pura. Ora, se, como já dissemos, a África é o ritmo, essa nova poesia vai dançar, girar e deslocar-se segundo ritmos antes desconhecidos". 147

O negro no modernismo não será apenas objeto ou tema de poesia, mas uma autêntica inspiração para uma renovação formal. Mas essa incorporação inédita de nosso elemento africano interno só se tornou possível porque foi ladeada por uma conjuntura favorável, que incluía amplos questionamentos estético-formais na Europa (também voltada para a África nesse momento) e no Brasil. Ademais, ocorreu um desenvolvimento de estudos sócio-antropológicos que re-significaram a influência da cultura africana sobre a brasileira ${ }^{148}$. Esses ensaios e estudos

\footnotetext{
${ }^{144}$ Idem. p. 109.

145 Idem. p. 110.

${ }^{146}$ Roger Bastide. Op. cit. p. 50.

147 Idem. p. 53.

${ }^{148}$ Roger Bastide evoca os trabalhos de Nina Rodrigues e sua escola, além de Casa-Grande \& Senzala de Gilberto Freyre. Idem. p. 40. Antonio Candido também vê no ensaio modernista a influência de Nina Rodrigues, Silvio Romero e Euclides da Cunha. Antonio Candido. Op. cit. 1965/2000. p. 113.
} 
científicos, segundo Bastide, forneceram documentação e material a ser transposto poeticamente, além de ajudarem os poetas em sua crítica das estruturas mentais das velhas gerações.

Segundo Antonio Candido, essa união entre etnografia, primitivismo e modernismo acabou resultando em uma combinação que fazia ainda mais sentido no Brasil do que na Europa: "Finalmente não se ignora o papel que a arte primitiva, o folclore e a etnografia tiveram na definição das estéticas modernas, muito atentas aos elementos arcaicos e populares comprimidos pelo academismo. Ora, no Brasil as culturas primitivas se misturavam à vida cotidiana ou são reminiscências ainda vivas de um passado recente. As terríveis ousadias de um Picasso, um Brancusi, um Max Jacob, um Tristan Tzara, eram, no fundo, mais coerentes com a nossa herança cultural do que com a deles. O hábito em que estávamos do fetichismo negro, dos calungas, dos ex-votos, da poesia folclórica, nos predispunha a aceitar e assimilar processos artísticos que na Europa representavam uma ruptura profunda com o meio social e as tradições espirituais. Os nossos modernistas se informaram pois rapidamente da arte européia de vanguarda, aprenderam a psicanálise e plasmaram um tipo ao mesmo tempo local e universal de expressão, reencontrando a influência européia por um mergulho no detalhe brasileiro”. ${ }^{149}$ É da imersão no exótico interno, no nosso desvio da regra européia, que surgiu nossa “originalidade” artística e, com ela, uma maior relevância poética da negritude.

Dentre os vários modernistas que compuseram poemas com a temática negra, mais especificamente da escravidão doméstica feminina, destaca-se Cassiano Ricardo. Segundo Alfredo Bosi, o escritor, no seu início de carreira, apresentava uma faceta poética mais acadêmica, tendo até mesmo um livro neo-parnasiano, A frauta de Pã. Contudo, o autor renovouse radicalmente sob a influência do Modernismo. ${ }^{150}$ Em Vamos caçar papagaios, de $1926^{151}$, iniciou sua produção modernista, já influenciada pelo movimento Verdeamarelista de Menotti Del Picchia, Cândido Motta Filho e Plínio Salgado. Nessa obra, o Brasil tupi e colonial é tematizado. O Brasil-Colônia é metaforizado, por exemplo, na poesia “Sangue Negro”, com a escravidão do personagem Pai João. Em 1928, Cassiano Ricardo publicou Martim Cererê $^{152}$, considerada uma das obras fundamentais para a inteligência do modernismo, juntamente com Macunaíma (de Mario de Andrade) e Cobra Norato (de Raul Bopp). Neste livro, o poeta narra as diferentes aventuras de Zozé, Columi e Ioiô que, apesar de viverem histórias remetidas à temática

\footnotetext{
${ }^{149}$ Antonio Candido. Op. cit. 1965/2000. p. 111 e 112.

${ }^{150}$ Alfredo Bosi. Op. cit. p. 335.

${ }^{151}$ Cassiano Ricardo. "Vamos caçar papagaios" in: Poesias Completas. Rio de Janeiro, Editora José Olympio, 1926/1957.
} 
paulista - desde os índios, passando pelos bandeirantes até chegar à produção cafeeira -, foram alimentados por amas-de-leite escravas. A opção por tratar o nacional a partir de uma temática paulistana também está presente no ensaio Marcha para o Oeste, e talvez se justifique pelas origens do autor: nasceu em 1895, na cidade de São José dos Campos. Também na capital paulista, estudou Direito. Integrou a Academia Paulista de Letras e a Academia Brasileira de Letras, a partir de 1937, lutando pelo reconhecimento oficial dos poetas modernos. Até o fim da vida continuou produzindo poesias e realizando importantes experiências concretistas. ${ }^{153}$

Raul Bopp, outro autor da importante tríade “primitivista” do modernismo brasileiro, também escreveu poemas sobre a mãe-preta. Assim como fizeram Mario de Andrade e Cassiano Ricardo, o poeta, em Cobra Norato, debruça-se sobre uma temática folclórica que é misturada aos mitos e ao primitivismo presentes em nossa cultura, fosse ela de matriz indígena, ou negra. Em Urucungo ${ }^{154}$, o escritor trabalha diretamente o primitivismo africano, em seus temas e linguagem. Uma das principais temáticas trazidas por Bopp, segundo Bastide, foi o "banzo”, o devaneio desolado (presente na música e na dança que tentam ressuscitar a terra perdida) que faz do negro uma figura ainda exótica, dentro do exotismo brasileiro construído por brancos. ${ }^{155}$ No poema em que se refere à mãe-preta, a personagem central exprime uma nostalgia profunda por tudo que lembrasse a África. O poeta, para além desse exotismo surgido pela evocação da saudade, também explorou e experimentou a nova sonoridade da poesia afro-brasileira, fazendo uso de todo um vocabulário afro ainda poeticamente inexplorado.

Esse profundo conhecimento folclórico talvez se explique um pouco pela atribulada trajetória de vida de seu autor. Nascido no ano de 1898, na cidade Tupaceretã, Rio Grande do Sul, ele descendia de uma família de imigrantes alemães. Estudou Direito em vários lugares, além de ter exercido diversas profissões (desde jornalista, a pintor de paredes ou caixeiro-viajante), enquanto viajava por todo o país. Na década de 1920, percorreu demoradamente a Amazônia, foi até Cuiabá e chegou a Buenos Aires. Além disso, viajou muito pelo mundo afora; desde as selvas africanas, asiáticas, até as americanas. Por onde passou, fez amigos: no Rio de Janeiro, Cassiano Ricardo e André Carrazoni; em Pernambuco, José Lins do Rego. Em São Paulo, poucos anos após a Semana de Arte Moderna, aproximou-se de vários sub-grupos modernistas, integrando inicialmente o Verde-amarelo; já em 1928, ligou-se a Oswald de Andrade e Tarsila do Amaral,

\footnotetext{
${ }^{152}$ Cassiano Ricardo. Martim Cererê: O Brasil dos meninos, dos poetas e dos heróis. São Paulo, Edição Saraiva, 1928/1962.

${ }^{153}$ Dados biográficos retirados de Alfredo Bosi. Op. cit. p. 365 e 366.

${ }^{154}$ Raul Bopp. Urucungo. Rio de Janeiro, Ariel, 1932.

${ }^{155}$ Roger Bastide. Op. cit. p.50.
} 
padroeiros da Antropofagia. Seguiu a carreira diplomática sempre simultânea ao jornalismo, o que contribuiu para que continuasse a viajar até o fim de sua vida. ${ }^{156}$

Mas a poesia primitivista não foi a única vertente poética do movimento modernista. Ele, ao contrário, possuía muitas dissensões internas para além do racha entre Pau-Brasil e Verdeamarelismo - que se transfiguraram respectivamente em Revista de Antropofagia e Anta. “À parte, hesitantes entre as novas liberdades formais e a tradição simbolista, agrupam-se os ‘espiritualistas’ da Festa (1927)”. ${ }^{157}$ Festa é o nome do grupo composto por Tasso da Silveira, Barreto Filho, Adelino Magalhães, Gilka Machado e Murillo Araújo, que culminou numa revista de mesmo nome publicada em 1927-1928 e 1934-1935. Numa segunda fase desse mesmo movimento, Cecília Meireles e Murilo Mendes também passariam a integrar o grupo. Foi, contudo, Murillo Araújo quem compôs uma poesia em homenagem à mãe-preta, em seu livro $A$ iluminação da vida ${ }^{158}$, premiado pela Academia Brasileira de Artes. Nascido em Serro Frio (MG) no ano de 1894, mudou-se para o Rio de Janeiro em 1907, para estudar no Colégio Pedro II onde, tempos depois, lecionou por muitos anos. Foi também nesta cidade em que bacharelou-se em Direito. Teve íntimo contato com o simbolismo, tanto no Rio de Janeiro como em São Paulo, a ponto dessa corrente influenciar também a poesia modernista que compunha. Segundo Alfredo Bosi, uma das faces de sua obra poética possuía um tom saudosista, rítmico, de cunho pessoal, as vezes ingênuo e tímido. ${ }^{159}$

Existiram outras vertentes do modernismo principalmente em Minas Gerais, Rio Grande do Sul, ou mesmo no Nordeste, capitaneado pelo Recife. Os regionalistas do Recife, que se congregaram entre 1925-1926 em torno de Gilberto Freyre, não tinham um projeto propriamente literário. No entanto, o grupo promoveu um debate em consonância com as inovações modernistas, principalmente a partir da década de 1930; sobretudo na poesia de Jorge de Lima e no romance de José Lins do Rego.

Jorge de Lima, que fora no começo da carreira um apreciado poeta neo-parnasiano, depois de entrar em contato com o modernismo e regionalismo do Nordeste, produziu uma poesia social e de temática negra. Numa terceira fase, dedicou-se a uma obra de tom eminentemente religioso. Em todos esses momentos sua poesia é, segundo Bosi, “organicamente lírica, isto é, enraizada na própria afetividade mesmo quando aparenta dispersar-se em notações pitorescas, em ritmos

\footnotetext{
${ }^{156}$ Dados biográficos retirados de Alfredo Bosi. Op. cit. p. 369 e de Raimundo de Menezes. Dicionário literário brasileiro. Op. cit. p. 121.

${ }^{157}$ Alfredo Bosi. Op. cit. p. 343.

${ }^{158}$ Murillo Araujo. A illuminação da vida. Rio de Janeiro, sem editora, 1927.
} 
folclóricos, em glosas dos grandes clássicos”. ${ }^{160}$ Esse mergulho em torno de si próprio não se faz apenas pela afetividade, mas também pela memória e pelo inconsciente. Em Poemas, Novos Poemas e Poemas Escolhidos ${ }^{161}$ têm na memória infantil o seu mais forte móvel. O autor, nascido em 1895, em União dos Palmares, Alagoas, via de perto de sua casa a Serra da Barriga, onde se estabelecera, no passado, o quilombo dos Palmares, e cujas histórias escutava desde a infância. O abolicionismo também fazia parte de seu imaginário infantil, posto que o pai e o avô materno pertenciam ao movimento, não aceitando em suas propriedades o trabalho dos escravos. A escravidão é, portanto, uma marca profunda em suas memórias, levando mesmo a peculiaridades em sua sensibilidade poética. Em Poemas Negros ${ }^{162}$, vozes e ritmos da linguagem afro-brasileira dão acesso a uma religiosidade mística e terrena, muito influenciada pela cultura africana. Nesse livro também estão presentes inúmeras reminiscências da infância: “a poesia de Jorge de Lima é a saudade da infância. Saudade das ladeiras que ele percorria em menino, saudades das pretas que se banhavam no rio, saudade dos bangüês em que a negra fulô penteava a sinhá-moça e acalentava o bebê com lendas estranhas. Mas, acima de tudo, o leite branco da mãepreta, o gosto desse leite na boca risonha da criança”. ${ }^{163}$ Para Bastide, ser alimentado pelo leite das amas negras era equivalente a ter acesso a uma espécie de “doçura única”, a qual ele só pôde experimentar por meio da poesia de Jorge de Lima: “Mas eu não tive, para acalentar minha infância, a canção de uma mucama, e meus lábios não conheceram a doçura do leite de uma negra. Os Poemas Negros, de Jorge de Lima, foram para mim um pouco como esse leite nutritivo, esse leite que traz consigo tanta beleza e tanta poesia”. ${ }^{164}$ Mas não só em Poemas Negros, mas em todos os livros mencionados, há referências às mães-pretas em várias poesias, nem que seja em poucos versos, ou ainda fazendo uso de seu nome para compor metáforas com a natureza.

Jorge de Lima deixou a terra natal em 1911, para estudar medicina na Bahia, mas acabou por concluir seus estudos no Rio de Janeiro. Voltou a Alagoas em 1916, onde lecionou e

\footnotetext{
${ }^{159}$ Dados biográficos retirados de Alfredo Bosi. Op. cit. p. 343 e de Raimundo de Menezes. Dicionário literário brasileiro. Op. cit. p. 63.

${ }^{160}$ Alfredo Bosi. Op. cit. p. 452.

${ }^{161}$ Respectivamente publicados em 1927, 1929, 1932 e todos constam em sua obra completa: Jorge de Lima. Poesia Completa - volume I. Rio de Janeiro, Nova Aguilar, 1974.

${ }^{162}$ Parte do conteúdo do livro foi publicada numa versão preliminar em 1937, sob o título Quatro Poemas Negros. A publicação, em versão definitiva, sob o título Poemas Negros ocorreu somente em 1947, numa edição que contava com ilustrações de Lasar Segall, além de prefácio de Gilberto Freyre. Jorge de Lima. Poemas Negros. Rio de Janeiro, Editora da Revista Acadêmica, 1947.

${ }^{163}$ Roger Bastide. "Doçura do Leite das Negras” in: Letras e Artes - Suplemento literário do jornal A Manhã. Rio de Janeiro, 22/02/1948. p. 5.

${ }^{164}$ Idem.
} 
trabalhou como médico, além de construir uma carreira política. Retornou ao Rio de Janeiro novamente em 1930, após sofrer um atentado (aparentemente de motivação política), e continuou a clinicar até quase o fim da vida em 1953.

José Lins do Rego fazia parte do mesmo grupo regionalista do Nordeste a que pertencia Jorge de Lima. Sua grande contribuição foi, contudo, no romance, e não na poesia, como fora o caso de Jorge de Lima. O romancista, nascido em 1901, no Engenho Corredor, no município do Pilar, Paraíba, evoca em seus livros esse seu universo da infância vivida num Nordeste de engenhos e bangüês. Ele começou a escrever em 1923; mesmo ano em que se formara advogado pela Faculdade de Direito do Recife. Foi nessa época que se tornou amigo de Gilberto Freyre; ambos travaram contato com outros literatos do Nordeste, entre eles José Américo de Almeida, Osório Borba, e Aníbal Fernandes, dentre outros. Desistiu cedo da carreira de magistrado, passando a morar em Alagoas, onde escreveu sua obra de estréia, intitulada Menino de Engenho $^{165}$. Nela, segundo Alfredo Bosi, o romancista “descendente de senhores de engenho (...) soube fundir numa linguagem de forte e poética oralidade as recordações da infância e da adolescência com o registro intenso da vida nordestina colhida por dentro, através de processos mentais de homens e mulheres que representam a gama étnica e social da região”. ${ }^{166} \mathrm{O}$ autor mesclava em seu texto tanto as memórias da infância quanto a observação daquele cotidiano nordestino permeado por amas-de-leite e negras velhas contadoras de histórias, que se tornam personagens nos romances, e inspiração para a composição de uma obra de literatura infantil: Histórias da Velha Totonia ${ }^{167}$.

Em 1935, adentra o funcionalismo público, passando a residir no Rio de Janeiro, cidade em que também trabalhava como jornalista, sobretudo na área de esportes. Em 1955, foi eleito para a Academia Brasileira de Letras, morrendo em 1957, poucos meses depois de tomar posse de sua cadeira.

A última obra literária a ser analisada, que traz representações da mãe-preta, é BrasilCanção $^{168}$. Ela foi composta por Antonieta Borges Alves ${ }^{169}$, e publicada a propósito da comemoração do IV Centenário da cidade de São Paulo, em 1954. O livro é composto por poemas que evocam uma vida cotidiana, de tons regionalistas, além de tematizar algumas figuras folclóricas. Entre as poesias, há uma dedicada à mãe-preta, e outra a pai-joão.

\footnotetext{
165 José Lins do Rego. Menino de Engenho. Rio de Janeiro, Livraria José Olympio Editora, 1932.

166 Alfredo Bosi. Op. cit. p. 398.

167 José Lins do Rego. Histórias da Velha Totonia. Rio de Janeiro, Livraria José Olympio Editora, 1936.

168 Antonieta Borges Alves. Brasil - Canção. São Paulo, Escolas Profissionais Salesianas, 1954.

${ }^{169}$ Em minha pesquisa, nada consegui encontrar da biografia de Antonieta Borges Alves.
} 
Mas analisarei ainda outro nicho literário em que a mãe-preta esteve em voga por muito tempo: a literatura infantil brasileira.

\section{A mãe-preta na literatura infantil brasileira}

É por volta de 1890, num contexto ainda marcado pela abolição da escravidão e a pela Proclamação da República, que se pode perceber uma maior preocupação em torno da criação de uma literatura infantil no Brasil. A mudança do sistema de governo levou à tentativa de inauguração de novos modelos de nacionalidade, não mais referidos à realeza. Nesse contexto, portanto, a educação infantil - socializadora de valores - adquire grande importância; e os livros, que lhe serviam de instrumento didático, passam a ser repensados. A literatura infantil ganha, desse modo, evidência justamente por transmitir valores morais, condutas a serem seguidas e virtudes de maneira aceitável pelas crianças.

Mas esse gênero específico surgira do trânsito entre a literatura oral e a escrita. Em seus primórdios, limitava-se a registrar as histórias antes transmitidas oralmente. “As primeiras formas de literatura para crianças confundiam-se com as destinadas aos adultos e, no Brasil, chegaram com os primeiros colonizadores portugueses. Tais formas seriam, evidentemente, as narrativas orais que circulavam entre os povos e as cortes européias, cujas origens se perdiam no tempo. Narrativas que, transformadas ou fragmentadas, podem ser rastreadas, hoje, tanto no folclore português (ou europeu em geral), como no folclore brasileiro (principalmente do Nordeste). Portanto, no Brasil, como nos demais países, a literatura em forma de livro (para crianças ou adultos) foi precedida pela forma oral”. 170

A mistura destes registros tem, sobretudo, papel privilegiado na literatura infantil, que muitas vezes faz uso dos serões em suas narrativas. Até meados dos anos 1940, são esses tipos de história que ainda têm precedência. O primeiro livro infantil que trouxe representações da mãepreta apresentava essas características; estava estruturado sob a forma de um serão, em que mãepreta conta histórias de bichos para os filhos brancos de sua sinhá. O livro reproduzia na linguagem escrita, portanto, histórias do universo oral. Refiro-me, especificamente, a Serões da Mãe Preta - Contos populares para crianças, escrito por Luiz Demétrio Juvenal Tavares. ${ }^{171}$ Esse pequeno livro era precedido de um prólogo, em que o autor explicava quem era a mãe-preta, sua

\footnotetext{
${ }^{170}$ Nelly Novaes Coelho. Dicionário crítico da literatura infantil e juvenil brasileira. São Paulo, Edusp, 1995. p. 20.

${ }^{171}$ Luiz Demétrio Juvenal Tavares. Serões da Mãe Preta - Contos populares para crianças. Belém, Fundação Cultural do Pará Tancredo Neves, 1890/1990.
} 
origem histórica e importância. Isto é, esclareceria didaticamente para os leitores mirins quem era a narradora das histórias que transcrevia.

Luiz Demétrio Juvenal Tavares parece ter sido um intelectual de circulação apenas regional, que se interessou pelo folclore e pelas tradições igualmente regionais. Nascido em 1850, na cidade de Cametá, no Pará, Tavares educou-se no Seminário de Belém, de onde só saiu em 1872, quando tinha 22 anos. A partir daí, investiu em sua carreira jornalística, passando por inúmeros jornais de tendências liberais, abolicionistas e republicanas; entre eles: A Tribuna, $O$ Camataense, Diário de Notícias e A Província do Pará. Desse último, tornou-se redator em 1886. Suas primeiras publicações coincidem com seu ingresso no mundo dos periódicos. Em 1873 publicou Pirilampos, uma compilação de seus versos escritos desde os 15 anos de idade. Quatro anos depois lançou seu segundo livro de poemas, intitulado Paraenses. Em 1887, chega ao mercado seu terceiro livro, composto por versos populares - chamado A Viola de Joana - que foi dedicado aos proletários do Pará. Em 1890, vem a público A Vida na Roça e Serões da Mãe Preta; esses últimos, segundo Vicente Salles (seu biógrafo), fixavam “versões correntes no seu tempo de fenômenos da literatura oral, em seus vários aspectos, todos eles dignos de consideração, não só pelo registro em si, mas pelo estilo da narrativa espontânea, simples, muito próximo da expressão oral”. ${ }^{172}$

Serões da Mãe Preta foi aprovado e adotado pelo Conselho Superior de Instrução Pública do Pará. Essa indicação talvez esteja relacionada com a nomeação do autor, em 1890, para o cargo de secretario interino da Instrução Pública do Estado do Pará. Não se sabe se Tavares chegou a assumir a posição mas, de qualquer forma, é sintomático que um livro para crianças cuja figura central é a mãe-preta - tenha contado com a aprovação do Estado.

Por causa de sucessivas brigas políticas, Tavares passou por vários jornais e cargos públicos. Seu último emprego formal foi como funcionário da Inspetoria das Águas, do qual foi demitido em 1901. Morreu em 1907, em estado de penúria, em Soure, na ilha de Marajó. Em seu registro de óbito figurava como profissão: pescador.

Esse apelo ao oral, ao folclórico, e ao passado, comum na literatura infantil, contribuía também para a consolidação de uma imaginação nacional agenciada pela contínua transmissão das mesmas histórias folclóricas por várias gerações. Como diz Andréa Borges Leão: “além do alcance e efeito simbólico, esses livros poderiam ser inseridos num sistema de referências folclóricas que trazia à tona do escrito uma memória nacional, certas imagens e formas de

\footnotetext{
${ }^{172}$ Vicente Salles. "Luiz Demétrio Juvenal Tavares - Cronologia" In: Serões da Mãe Preta. Belém, Secretaria de Estado da Cultura/Fundação Cultural do Pará Tancredo Neves, 1890/1990. s.p.
} 
oralidade. Os livros de imaginação literária destinados às crianças foram espaço privilegiado para o encontro entre as formas orais e a forma escrita."

É interessante pensar que essa ênfase no folclórico e no oral, existente nos livros para crianças, deu-se simultaneamente com um grande surto de modernização (marcada pela reforma urbana, pela higienização pública e pela voga de uma moda cosmopolita entre as elites), ocorrido durante a Belle Époque, principalmente em São Paulo e Rio de Janeiro. Nesses tempos de muito entusiasmo pela “modernidade”, os livros infantis evocavam um passado bucólico, memórias longínquas, retomando ainda a histórias folclóricas desde há muito transmitidas oralmente. Esse tom saudosista, de enaltecimento de um passado glorioso que se esvaía com a civilização revela, por sua vez, um certo desajuste entre o contexto das modernizações exaltadas e o imaginário que cercava os autores dessa "República de Letras”.

Esse descompasso poderia assinalar ainda a frustração que assolou esses escritores com a emergência da República: um governo que tinham ajudado a fundar e no qual foram rapidamente preteridos, em nome da estabilização de uma “mediocracia cavadora de cargos” no Estado. ${ }^{174}$ "No microcosmo das letras, os produtores culturais decerto moviam-se no saracoteio literário das rodas e cafés, investindo nas estratégias comerciais de animação mundana, mas essa singular 'inteligência nacional' vivia mesmo era sob o retorno às formas de oralidade, em constante tematização dos 'tempos idos': tempos da carochinha, da avozinha, do arco da velha. Os escritores consagrados, seja pelos títulos publicados, seja por uma vida literária, lançavam-se numa busca obstinada do elo perdido com a voz que transmite os textos. Daí as páginas nostálgicas de Coelho Neto, Afrânio Peixoto, Sílvio Romero, Olavo Bilac, Viriato Correia, entre tantos.”"175

Concluindo, esses autores, conhecidos por conta de suas obras literárias, e por suas colaborações no universo infantil, tinham como tema os saudosos tempos de antanho, e não a “civilização moderna”, que eles também ajudaram a implantar. Essa perda paulatina da tradição, lamentada pelos autores, acabou tornando-se justamente o elemento que deveria ser perpetuado na imaginação infantil. São os tempos do arco da velha, das histórias contadas pelas pretas velhas, amas e avós, que aparecem agora adequados à socialização infantil. Os autores evocam a lembrança da experiência socializadora que tiveram em sua infância para compor os livros que

\footnotetext{
${ }^{173}$ Andréa Borges Leão. Brasil em Imaginação - Livros, Impressos e Leituras Infantis (1890- 1915). São Paulo, Tese de Doutorado em Sociologia, FFLCH-USP, 2002. p. 46

${ }^{174}$ Sobre esse sentimento de angústia e frustração que permeava os intelectuais da Primeira República vide Nicolau Sevcenko. Literatura como Missão: tensões sociais e criação cultural na Primeira República. São Paulo, Companhia das Letras, 1983/2003. Especialmente cap. 2.

${ }^{175}$ Andréa Borges Leão. Op. cit. p. 40.
} 
entretêm e educam as crianças desses tempos de transformações necessárias, mas parcialmente condenáveis.

Essa é a linha seguida por Olavo Bilac e Coelho Netto no livro infantil que publicaram em 1894, intitulado Contos Pátrios para crianças $^{176}$. Na obra há um conto, de autoria de Bilac, que traz a história de “Mãe Maria”, uma escrava, mãe de criação que contava histórias para o menino Amâncio.

O poeta parnasiano teve uma importante produção infantil que contou com diversos colaboradores. Seus textos procuram documentar a "realidade brasileira” e transmitir "valores cívicos e morais” contribuindo para a formação de futuros “cidadãos conscientes”. Entre esses valores encontram-se as "idéias humanitárias” que enaltecem os pobres dignificados pelo trabalho, simples e felizes. Esse "humanitarismo" está presente na caracterização que Bilac faz de Mãe Maria; uma velha negra africana que tinha um amor extremado por seu sinhozinho.

O envolvimento do autor com a literatura infantil ocorreu principalmente em função de sua carreira profissional. Nascido em 1865, no Rio de Janeiro, Bilac não concluiu nenhum dos cursos superiores iniciados; nem o de Medicina, nem o de Direito. Desde cedo dedicou-se ao jornalismo e à literatura, tirando daí o seu sustento. Em 1898, o autor assumiu, mediante concurso, o cargo de inspetor escolar do Distrito Federal, no qual trabalhou por muitos anos até se aposentar. ${ }^{177}$ Teve ainda uma vasta produção didática e paradidática de Bilac ${ }^{178}$, sempre publicada por Francisco Alves.

A ampla produção de Bilac, e suas sucessivas reedições, revelam que o mercado literário infantil ia consolidando seu público no início do século XX. Os periódicos e impressos, que tinham o baixo preço como principal atrativo, também contribuíram para tal fenômeno. O primeiro jornal infantil, a Gazeta das Crianças, um suplemento da Gazeta dos adultos, passou a circular a partir de 1903. Seu editor mais famoso foi Viriato Corrêa, que fez larga carreira na literatura infantil. “A Gazeta das Crianças oferecia a seus leitores uma 'conversa' instrutiva de nome 'sciencia fácil', dava notícias de batizados, aniversários, publicava cartas dos leitores, contos, versos, anedotas enviadas pelas crianças, anúncios de brinquedos e livros, além de abrir concursos de prêmios. Nas páginas do jornal, esta coluna propunha-se recreativa e instrutiva; os

\footnotetext{
${ }^{176}$ Olavo Bilac e Coelho Neto. Contos Pátrios para crianças. Rio de Janeiro, Francisco Alves \& Cia, 1894/1918, 16 edição.

${ }_{177}$ Dados biográficos retirados de Nelly Novaes Coelho. Dicionário crítico da literatura infantil e juvenil brasileira. Op. cit. p. 46.

${ }^{178}$ Entre estas obras estão: A terra fluminense (1898), Livro de Composição (1899), Livro de leitura (1900), Poesias Infantis (1904), Teatro Infantil (1905), e Pátria Brasileira (1909)
} 
torneios, por exemplo visavam a 'desenvolver a intelligencia e a applicação dos camaradinhas'.,179

O semanário infantil O Tico Tico, fundado em 11 de outubro de 1905, era mais voltado para a diversão e o lazer. Esse primeiro periódico inteiramente infantil foi um marco na estrutura empresarial de uma imprensa para crianças; publicado por mais de 55 anos, encerrou suas atividades apenas em meados de 1962. O público alvo da "avesinha” - termo pelo qual o jornal era conhecido - eram as crianças entre seis e catorze anos. Mas, para os menores, também existiam colunas específicas, como as "histórias em imagens”, destinadas para aqueles na faixa entre um e três anos de idade.

No primeiro volume do jornal, os redatores logo se apresentaram ao público - contavam com a colaboração de Manoel Bonfim e de Coelho Neto, além de vários ilustradores famosos como J. Carlos - e deixaram claros “os objetivos do semanário: (...) 'este jornalzinho para empregar uma chapa inevitável vem preencher uma lacuna. É um jornal que se destina exclusivamente ao uso, à leitura e ao prazer, à distracção das crianças. Não queremos a attenção nem o aplauso da gente grande: os pequeninos, os innocentes, os simples formarão o nosso público. É para elles que escrevemos - e si conseguirmos agradar-lhes, teremos obtido o único triumpho que ambicionamos”. ${ }^{180}$ No embalo desse duradouro empreendimento, e no momento de um surto de nacionalismo editorial, em meados da década de 1930, a Sociedade Anônima “ $O$ Malho” lança sua Bibliotheca Infantil d'O Tico Tico, inaugurada com o livro de Oswaldo Orico Contos da Mãe Preta - adaptados à leitura das crianças. ${ }^{181}$

Segundo Zita de Paula Rosa: “diante das imposições do mercado para a produção de obras didáticas, passíveis de circularem em salas de aula, os diretores da Sociedade Anônima 'O Malho' decidiram aproveitar melhor a infra-estrutura material e os recursos humanos de que dispunham. Investiram, então, na edição de livros para crianças de autores nacionais como Osvaldo Orico, Carlos Manhães de Queirós, Humberto de Campos e Josué Montello, como forma de iniciarem a coleção Biblioteca Infantil de 'O Tico Tico'. Estas obras passaram a integrar as bibliotecas públicas e semi-públicas, cuja criação experimentou grande impulso em meados dos anos trinta."182 Mas a escolha dos autores dessa biblioteca infantil não foi casual, eram escritores renomados, já conhecidos dos adultos que a compunham. No caso de Orico, havia o diferencial

\footnotetext{
${ }_{179}^{179}$ Andréa Borges Leão. Op. cit p. 116 e 117.

180 Idem. p. 222 e 223.

${ }^{181}$ Oswaldo Orico. Contos da Mãe Preta - adaptados à leitura das crianças. Rio de Janeiro, Bibliotheca Infantil d'O Tico-Tico, série I, volume I, 1932.
} 
dele ser afamado por seus empreendimentos no campo da educação; o que garantiria para a editora um sucesso de vendas, caso o livro fosse recomendado pelo governo para integrar as bibliotecas públicas ou para ser adotado pelas escolas.

Osvaldo Orico nasceu em 1900, em Belém, Pará, radicando-se no Rio de Janeiro, onde se formou em Direito, e desenvolveu uma carreira de atuação pública, sobretudo nos meios educacionais dos anos 1920 - 1940. Foi professor na Escola Normal do Distrito Federal (19201932), diretor da Instrução Pública do Distrito Federal (RJ), diretor da Educação e Cultura do Estado do Pará (1933) e Ministro do Brasil junto à ONU, com sede em Paris, para assuntos ligados à Educação, Ciência e Cultura. Foi por conta de uma obra que tratava da educação no Brasil que, em 1928, Orico ganhou um prêmio da Academia Brasileira de Letras, a qual passou a integrar dez anos mais tarde. Além de professor e autor de literatura infantil, escreveu poesias, biografias, fez traduções e livros sobre folclore. ${ }^{183}$

Foi enquanto professor e diretor da Instrução Pública do Distrito Federal que Orico produziu suas obras de literatura infantil, entre elas Contos da Mãe Preta - adaptados à leitura das crianças $^{184}$ e Historias de Pae João - Contos do folk-lore brasileiro adaptados à leitura das crianças $^{185}$, ambos pertencentes a Bibliotheca Infantil d'O Tico-Tico.

Foi, portanto, como parte desse projeto de entretenimento dos editores d'O Tico-Tico, mas com preocupações pedagógicas garantidas por sua atuação no campo da educação, que o autor compôs seu livro infantil no qual há uma representação da mãe-preta no prólogo. Nesse preâmbulo da obra, ele tenta explicar didaticamente a figura nacional da mãe-preta, e o modo como ela teria inspirado o livro que a traz como título. No entanto, no corpo do livro, a mãe-preta não volta a ser citada: são apenas transcritas dezessete conhecidas histórias folclóricas.

Viriato Correia foi outro autor ligado ao jornalzinho Tico-Tico, que publicou um livro infantil onde há a mesma figura da negra velha contadora de histórias. Escritor de múltiplos talentos, tendo produzido contos, romances, crônicas, livros de História e de literatura infantil; foi nessa última área que ele alcançou maior sucesso, em função de seu best-seller Cazuza ${ }^{186}$. É justamente nele que aparece a preta "Vovó Candinha”. O livro conta a história de Cazuza, que decide escrever suas memórias de infância desde o momento em que entra na escola do povoado,

\footnotetext{
${ }^{182}$ Zita de Paula Rosa. O Tico Tico - Mito da Formação Sadia. São Paulo, Tese de Doutorado em História/FFLCH USP, 1991. p. 60 e 61.

${ }_{183}$ Nelly Novaes Coelho. Dicionário crítico da literatura infantil e juvenil brasileira. Op. cit. p. 47 e 48.

${ }^{184}$ Oswaldo Orico. Contos da Mãe Preta - adaptados à leitura das crianças. Op.cit.

185 Oswaldo Orico. Historias de Pae João - Contos do folk-lore brasileiro adaptados à leitura das crianças. Série I, vol.11. Bibliotheca Infantil d'O TICO-TICO, Rio de Janeiro, [1933?].

${ }^{186}$ Viriato Correia. Cazuza. São Paulo, Companhia Editora Nacional, 1938.
} 
até chegar à vila e depois à cidade. Nesse percurso fala das “coisas e gentes” brasileiras, sempre em tom “humanitário", produzindo personagens exemplares.

Nascido em 1884, na cidade de Pirapema, Maranhão, já na adolescência Viriato mudou-se para o Rio de Janeiro, cidade onde se formou como advogado, e na qual faleceu, em 1967. Trabalhou em muitos jornais, mantendo por longo tempo uma coluna de crítica teatral, que o motivou a enveredar pelo campo da dramaturgia. Mas foi na literatura infanto-juvenil que produziu inúmeras obras folclóricas ${ }^{187}$ e paradidáticas, entre elas: Contos da História do Brasil (1928), Histórias da História do Brasil, A Descoberta do Brasil, etc. ${ }^{188}$

Ainda que Viriato Correia tenha atingido grande sucesso de público e criado uma obra reconhecida como de fácil comunicação junto ao público infantil, a crítica não o considera um criador original. ${ }^{189}$ Tampouco os escritores infantis até aqui mencionados (Luiz Demétrio Juvenal Tavares, Olavo Bilac e Oswaldo Orico) são tidos propriamente como autores de literatura infantil brasileira. Eles são tratados, de modo geral, como precursores dessa literatura que é inaugurada somente por Monteiro Lobato.

Essa produção, anterior à obra de Lobato, constitui as primeiras manifestações literárias infantis no Brasil; não chegam, contudo, a formar propriamente uma literatura infantil brasileira.

A primeira obra de Lobato nesse gênero literário foi O Saci, lançada em 1919. A segunda obra foi A Menina do Nariz Arrebitado, também escrita em 1919, mas lançada apenas em 1921, sendo reeditada, em versão modificada, dez anos depois, sob o título de Reinações de Narizinho. Este último livro inaugura a famosa série O Sítio do Picapau Amarelo, a qual revolucionou a literatura infantil brasileira. Assim, entre os anos 1920 e 1930 se forma a literatura infantil brasileira, tendo como marco a série infantil de José Bento Monteiro Lobato.

Nascido em 1882, na cidade de Taubaté, São Paulo, Lobato formou-se em Direito na capital paulista, tentando a carreira de promotor na cidade de Areias, abandonando-a após sete anos. Trabalhou como fazendeiro, mas tampouco seguiu na profissão. Dedicou-se à carreira jornalística, escrevendo para vários jornais; em alguns dos quais foi fundador. Comprou a Revista do Brasil e, a partir desse empreendimento, decidiu investir no mercado editorial criando, primeiramente, a Monteiro Lobato e Cia. (1918-1925) e, em seguida, a Companhia Editora Nacional (1925-1930) - são suas próprias editoras que publicam sua biblioteca infantil. ${ }^{190}$ Uma

\footnotetext{
${ }^{187}$ Entre elas, No país da bicharada, Arca de Noé, A Macacada, etc.

${ }^{188}$ Dados retirados de Nelly Novaes Coelho. Dicionário crítico da literatura infantil e juvenil brasileira. Op. cit. p. $1126-1129$.

${ }^{189}$ Idem. p. 1127.

${ }^{190}$ Luis Correia de Melo. Dicionário de Autores Paulistas. Op.cit. p. 312 - 314.
} 
das personagens principais do Sítio do Picapau Amarelo é uma negra velha, contadora de histórias, agregada da família, e tida como "negra de estimação”: Tia Nastácia. Nastácia tem inclusive um volume próprio intitulado Histórias de Tia Nastácia $(1937)^{191}$, no qual ela é regente de um serão, e conta histórias folclóricas que Lobato extraiu do livro de Silvio Romero, Contos Populares do Brasil ${ }^{192}$.

Simultaneamente, nesse período de consolidação de uma literatura infantil brasileira, as escolas - tão fundamental para o desenvolvimento dessa produção - passavam por profundas reformas em seus níveis Fundamental e Superior. Modificação da metodologia pedagógica, caráter laico, compulsório e gratuito do ensino: iniciativas isoladas e locais nos anos 1920, estenderam-se para o âmbito nacional na década subseqüente. Como diz Antonio Candido: “todas elas [medidas de reforma no ensino] visavam a renovação pedagógica consubstanciada na designação de 'escola nova', que representava posição avançada no liberalismo educacional, e que por isso foi combatida às vezes violentamente pela Igreja, então muito aferrada não apenas ao ensino religioso, mas a métodos tradicionais. Ora, a escola pública leiga pretendia formar mais o 'cidadão' do que o 'fiel', com base num aprendizado pela experiência e a observação que descartava o dogmatismo.”193

Percebe-se assim, como a preocupação governamental em torno da consolidação de uma formação básica - também modeladora do futuro cidadão - ao influir na escola acaba, igualmente, motivando a produção de uma literatura infantil brasileira.

Existiram, ainda, medidas diretas do governo concernentes a esse segmento. Prova disso foi a criação, em 29 de abril de 1936, da Comissão Nacional de Literatura Infantil, composta por Maria Junqueira Schmidt, Cecília Meirelles, Elvira Nizinska, Jorge de Lima, Murilo Mendes, José Lins do Rego e Manuel Bandeira. ${ }^{194}$ A comissão tinha seus cargos preenchidos por eminentes escritores que enveredaram, inclusive, pela literatura infantil ${ }^{195}$, e por professoras ligadas ao Instituto de Educação do Rio de Janeiro. Essa comissão, que avaliava os livros infantis, tinha como principal preocupação a literariedade das obras. Estas não poderiam ser apenas boas traduções e adaptações: tinham de ser composições literárias originais e artísticas,

\footnotetext{
${ }^{191}$ Monteiro Lobato. Histórias de Tia Nastácia. In: Sítio do Picapau Amarelo. Ribeirão Preto, Editora Brasiliense, 1937 /s.d. (Edição de Luxo).

192 Silvio Romero. Contos Populares do Brasil. Belo Horizonte, Editora Itatiaia, 1885/1995.

193 Antonio Cândido. "A Revolução de 1930 e a Cultura". In: Novos Estudos Cebrap. São Paulo, v.2, nº $4,1984$. p.28.

${ }^{194}$ Essas informações sobre a Comissão Nacional de Literatura Infantil encontram-se no arquivo privado de Gustavo Capanema, mantido pelo CPDOC/FGV, GCg 1936.04.29 (rolo 42; ft 814 a 1061).

${ }^{195}$ A obra infantil de José Lins do Rego será examinada mais adiante.
} 
que revelassem equilíbrio entre forma e conteúdo, entre os modos de expressão e valores veiculados.

Monteiro Lobato inaugura, portanto, a figura do autor e da grande obra de literatura infantil que envolvia a criação de histórias e personagens, cenários aliados a uma literariedade nos livros; tudo isso em meio a uma produção em que muitas vezes predominavam cópias adaptadas ou, ainda, o imediatismo de informações úteis e cívicas. As intervenções governamentais procuravam incentivar, mediante esse corpo de especialistas, escritores e pedagogos, uma nova literatura infantil brasileira. Esta se configuraria, por sua vez, como arte e entretenimento sadios, envolvendo agora criações originais, e não mais uma literatura quase instrumental de tão didática, ou somente adaptada.

Ofélia e Narbal Fontes formaram um casal que compôs uma vasta obra infantil, muito influenciada por essa renovação do pensamento pedagógico, principalmente pela linha da Escola Nova. Ofélia Fontes, nascida em 1902, em São Paulo, viveu no Rio de Janeiro, onde veio a falecer em 1986. Trabalhou como professora primária e técnica em educação, produzindo primeiramente "livros de leituras” para as séries primárias. Ampliou suas atividades, mantendo um programa chamado "Rádio Escola”, que tinha patrocínio do governo do Distrito Federal. Seu marido, nascido em Tietê no ano de 1899, foi médico e professor primário, além de escritor para crianças, sempre em colaboração com sua esposa. Faleceu também no Rio de Janeiro, em 1960. ${ }^{196}$

O livro de estréia de ambos na literatura infantil foi Pindorama - leitura para os alunos dos cursos primário e ginasial ${ }^{197}$. Tem como narrador o garoto Iberê, que falava nesse livro de lembranças sobre as coisas que aprendia em seu cotidiano. As outras personagens principais são seus pais e suas irmãs, além de Quitéria - a negra cozinheira agregada da família - e sua filha Isabel. A quituteira é quem, no livro, ensina a Iberê sobre as festas e as músicas folclóricas de sua terra natal, a Bahia. Em outros capítulos se transcrevem mitos e lendas sobre a origem da vitóriarégia, o milho, o mate, a mandioca e o café; explicam-se algumas figuras históricas como Anchieta, os bandeirantes e Zumbi, além de discorrer sobre a razão de alguns feriados nacionais como o Dia do Trabalho, recém-instituído por Getúlio Vargas. Nas informações transmitidas pelo livro, há uma preocupação em focar naquilo que constitui o país; seja a mistura das raças, o

\footnotetext{
${ }^{196}$ Dados retirados de Nelly Novaes Coelho. Dicionário crítico da literatura infantil e juvenil brasileira. Op. cit. p. 749.

197 Ofélia e Narbal Fontes. Pindorama - leitura para os alunos dos cursos primário e ginasial. Rio de Janeiro, Fernandes \& Rohe, 1932.
} 
folclore, a música ou mesmo a paisagem. "Lições humanitárias” também estão presentes nos capítulos dedicados aos mendigos, aos retirantes e à injustiça.

Os autores, numa nota prévia à obra, justificam algumas de suas opções: escolheram diferentes regiões do país para despertar mais curiosidade por esses diversos assuntos brasileiros; procuraram transmitir valores como um “ largo sopro de humanidade, de amor à justiça, ao trabalho, à democracia e uma profunda brasilidade”. 198

Uma personagem muito semelhante à cozinheira negra Quitéria está presente no livro As férias com a vovó ${ }^{199}$, de Maria Alves Velloso. Na obra, muitas crianças vão passar as férias na casa de sua avó, que vive na companhia de "Tia Jovita”: uma negra velha quituteira especialista em goiabadas e cocadas de abóbora, além de contadora de “causos de feitiço”.

Também é da década de 1930 a única incursão de José Lins do Rego na literatura infantil. O escritor, ligado a um certo grupo regionalista de Recife, reunido em torno da figura de Gilberto Freyre, publicou sua única obra infantil Histórias da Velha Totonia ${ }^{200}$ no mesmo ano - 1936 em que passou a integrar a Comissão Nacional de Literatura Infantil. Dessa maneira, é possível pensar que a composição de sua única obra infantil foi influenciada pelas ponderações da Comissão, que incluíam critérios pedagógicos e literários. Seu livro, mesmo impedido de participar do Primeiro Concurso promovido pela Comissão (uma vez que o autor era membro do júri), foi aprovado e recomendado para integrar as bibliotecas infantis de todo país.

A velha Totonia já fora personagem de seu primeiro romance Menino de Engenho ${ }^{201}$, mas aqui, na obra destinada às crianças, ela é retomada somente na abertura. Na verdade, trata-se de uma espécie de dedicatória aos meninos do Brasil e à própria Totonia; uma contadora de histórias inesquecível, a quem o autor gostaria de saber imitar a habilidade narrativa. No corpo do livro a negra não aparece, são apenas narradas quatro histórias folclóricas (“O macaco mágico”, “A cobra que era princesa”, “O príncipe pequeno” e “O sargento verde”), que foram retiradas do livro Contos Populares do Brasil ${ }^{202}$, de Silvio Romero.

Luís Jardim foi outro escritor de livros infantis, que também era ligado ao movimento regionalista de Recife. Nascido em 1910, em Garanhuns, Pernambuco, radicou-se no Recife e adentrou o mercado editorial como ilustrador, realizando pinturas e desenhos para inúmeros

\footnotetext{
198 Idem. p. 6.

${ }^{199}$ Maria Alves Velloso. As férias com a vovó. Rio de Janeiro, Livraria Francisco Alves, 1932. Procurei dados sobre a autora, no entanto não consegui mais informações, além da data de publicação da obra.

200 José Lins do Rego. Histórias da Velha Totonia. Rio de Janeiro, Livraria José Olympio Editora, 1936.

201 José Lins do Rego. Menino de Engenho. Rio de Janeiro, José Olympio Editora, 1932/1980.

202 Silvio Romero. Contos Populares do Brasil. Op. cit.
} 
livros. Algumas das obras que ilustrou eram de autores que, como ele, integravam o mesmo movimento regionalista.

Em seu livro de estréia como escritor (também como escritor infantil), O Boi Aruá ${ }^{203}$, Luís Jardim foi premiado no primeiro concurso de literatura infantil ${ }^{204}$, promovido pela Comissão Nacional de Literatura Infantil. A obra recebeu o primeiro lugar na categoria "Livro para crianças maiores de dez anos de idade”, sendo publicada em 1940 pela editora José Olympio. Tal fato impulsionou sua carreira, fazendo com que o autor se mudasse para o Rio de Janeiro. Lá, passa a colaborar na imprensa, ligando-se depois à área editorial, como autor, tradutor, adaptador e ilustrador. Em 1937, um outro livro, O Tatu e o Macaco, recebeu o $2^{\circ}$ lugar na categoria “Livros de Estampa” no Concurso do MEC. Como escritor para adultos, estreou oficialmente em 1939, com Maria Perigosa, uma reunião de contos regionais, onde já mostra uma mistura entre o efabulador popular e o culto. ${ }^{205}$

Seu primeiro livro premiado ( $O$ Boi Aruá), que traz a personagem da negra velha contadora de histórias, é composto por três contos - “O Boi Aruá”, "História das Maracanãs” e “História do Bacurau” - todas contadas por Sá Dondom; uma velha preta, num serão em sua casa. A estrutura do serão é, portanto, retomada na composição textual desse livro de histórias.

Wilson W. Rodrigues é outro autor de um livro infantil peculiar: trata-se de Pai João Menino $^{206}$, cujo narrador é justamente o filho preto de uma ama-de-leite escrava. Pai João Menino vai crescendo, numa convivência entre a casa-grande e a senzala, brincando com o sinhozinho branco, sendo maltratado por ele, mas sempre agindo com educação, transmitindo “lições de civilidade”. O autor, nascido em 1916, na cidade de Salvador, Bahia, foi jornalista, poeta e folclorista, tendo publicado, em poesia, Pai João (1945), Negrinho do Pastoreio (1945), Bahia Flor (1949) e Lendas do Brasil (1949); este último, especificamente sobre folclore. ${ }^{207}$

\footnotetext{
${ }^{203}$ Luís Jardim. O Boi Aruá. Rio de Janeiro, Livraria José Olympio Editora, 1940/1970.

204 "(...) Uma iniciativa diferencial foi a decisão de se organizar um concurso de livros infantis, cujo objetivo precípuo era estimular a redação de novas e boas histórias. (...) Assim, em setembro de 1936, é lançado um edital em que se instituem três concursos para livros de crianças conforme a faixa etária: até 7 anos de idade, de 8 a 10 anos e de mais de 10 anos. Os trabalhos deveriam ser originais, sendo entregues datilografados em três vias, assinados com pseudônimos, até 28 de fevereiro de 1937. (...) Em cada categoria seriam classificados três livros, recebendo o primeiro, o segundo e o terceiro colocados, respectivamente, prêmios de três, dois e um conto de réis." Angela de Castro Gomes. "As aventuras de Tibicuera: literatura infantil, história do Brasil e política cultural na Era Vargas" in: Brasil República - Revista da USP N ${ }^{\circ}$ 59. São Paulo, set/out/nov 2003.p.121.

${ }^{205}$ Dados biográficos retirados de: Nelly Novaes Coelho. Dicionário crítico da literatura infantil e juvenil brasileira. Op. cit.p. 624.

${ }^{206}$ Wilson W. Rodrigues. Pai João Menino. Rio de Janeiro, Arca Editora, 1945/1949. $3^{\text {a }}$ Edição.

${ }^{207}$ Dados retirados de Afrânio Coutinho e J. Galante de Sousa. Enciclopédia de Literatura Brasileira. São Paulo/Rio de Janeiro, Global / Fundação Biblioteca Nacional/ Academia Brasileira de Letras, 2001. vol. II. p. 1394.
} 
O que se pode extrair dessas considerações sobre como os negros - em especial a mãepreta - aparecem na literatura relaciona-se à permanência de suas representações nos mais diferentes movimentos literários e tipos de literatura, além da sua longa duração no tempo. Esses fatos me levam aos seguintes questionamentos: Por que há uma recorrência da figura da mãepreta no imaginário literário? Por que ela é uma das únicas personagens negras que tem longa vida literária no pós-abolição ${ }^{208} \mathrm{E}$, por último, por que constitui uma memória tão densa?

Essas são algumas das indagações que me levaram a selecionar como recorte para análise os anos entre 1880 - 1950, ou seja, o período pós-abolição. Esse recorte temporal também se justifica, uma vez que os literatos - que tomaram a mãe-preta como uma de suas figuras diletas compuseram suas obras no final da escravidão, imediatamente após o seu término (durante a Primeira República) ou, ainda, durante os anos do governo de Getúlio Vargas.

Com isso, não quero dizer que não existiram representações literárias da mãe-preta anteriormente a 1880. Como já fiz referências, havia personagens negras na produção literária simultânea à escravidão, e muitas são as obras que retrataram essas figuras. Raymond Sayers, em O Negro na literatura brasileira ${ }^{209}$, estudou inúmeras obras poéticas nas quais surgem as seguintes personagens negras: “o negro sofredor, que se revolta com a condição de escravo; o escravo fiel, espécie de anjo da guarda do senhor e de sua família; a mãe negra, dilacerada entre a felicidade da maternidade e a tragédia do cativeiro; e, sobretudo, a bela mulata."210 $\mathrm{Na}$ literatura dramática, Miriam Garcia Mendes analisou o perfil das personagens negras, em $A$ personagem negra no teatro brasileiro ${ }^{211}$. No teatro do século XIX, havia figuras negras que se pareciam muito com aquelas das obras poéticas; entre elas: o negro fiel, a mãe negra e os escravos domésticos corruptores da moral branca.

No romance urbano oitocentista, estudado por Jean M. Carvalho França, o negro aparece em diversas categorizações: muleques, criados de cor, mucamas, escravos de rua, capoeiristas,

\footnotetext{
${ }^{208}$ A mulata é outra personagem negra que também teve (e tem) longa vida literária e cultural depois da abolição. Teófilo de Queiroz Junior tratou da permanência desse estereótipo mediante a análise de um material vasto e eclético. Utilizou a literatura - passando por autores pertencentes ao Barroco, Romantismo, Naturalismo e Modernismo -, músicas de carnaval e textos científicos para entender a reincidência da figura. Vide: Teófilo de Queiroz Junior. Preconceito de Cor e a Mulata na literatura brasileira. São Paulo, Editora Ática, 1975.

${ }^{209}$ Raymond Sayers. O negro na literatura brasileira. Rio de Janeiro, Edições O Cruzeiro, 1958.

210 Essas conclusões de Sayers estão resumidas em Jean M. Carvalho França. "O negro no romance urbano oitocentista”. In: Estudos Afro-Asiáticos, Rio de Janeiro, n.30, dez., 1996. p.99. Grifos no original. O livro de Teófilo de Queiroz Junior também trata de algumas representações da mulata, simultâneas à escravidão, presentes nas obras de Gregório de Matos, Manuel Antonio de Almeida, Bernardo de Guimarães e Aluísio de Azevedo. A esse respeito vide: Teófilo de Queiroz Junior. Op. cit., sobretudo primeira e segunda partes.

${ }^{211}$ Miriam Garcia Mendes. A personagem negra no teatro brasileiro. São Paulo, Editora Ática, 1982.
} 
mulatas, e negros e negras velhas. ${ }^{212}$ Segundo o autor, nessa obra ficcional, os negros ocupavam papéis de seres de índole má e viciada: devassavam a intimidade dos patrões, eram uma péssima influência sobre os membros da família, inoculavam crendices e superstições, faziam “macumbas”, tinham uma sensualidade exacerbada, viviam na vadiagem e promoviam desordens na rua. Os negros e negras velhas constituíam a única exceção entre as personagens negras - não eram descritos de modo detrator ou negativo. “Ao contrário, os negros (ou negras idosos) das páginas dos romances eram aqueles de sua raça que gozavam de melhor reputação na cidade ficcional. Geralmente criados desde cedo no interior da casa patronal, além de fiéis e prestativos, esses elementos chegavam, em alguns casos, a participar ativa e positivamente da vida familiar. Há vários exemplos dessa boa convivência.”213 Coincidentemente, os negros e negras velhas mencionados como exemplo são aqueles escravos que viveram longamente com famílias brancas, e que nutriam verdadeiro afeto materno ou paterno pelas pessoas desse núcleo branco. Assim, no romance do XIX, novamente, a mãe-preta está entre as principais personagens negras evocadas.

A mãe-preta era, portanto, uma das personagens negras mais comuns na literatura contemporânea à escravidão. No entanto, o que eu gostaria de reter mais especificamente, são as razões pelas quais ela "permanece”, dentre as outras personagens negras, como figura dileta da literatura pós-abolição. Jean M. de Carvalho deu pistas que levam a uma possível resposta a tal pergunta, quando revelou que tanto as negras como os negros velhos (que eram pais afetivos de membros da família branca) eram as únicas personagens negras representadas "mais positivamente”.

A representação literária da mãe-preta, dessa forma, atravessa não só os diversos movimentos literários mas, inclusive, contextos sócio-históricos completamente distintos entre 1880 e 1950.

Até o momento, nessa revisão, procurei evidenciar as diferentes características de cada movimento, que influenciavam na produção dessas representações. Retomando essas características de modo ainda mais simplificado, pode-se dizer que havia a denúncia grandiloqüente da escravidão presente no romantismo, embora permeada por sentimentalismo, em alguns casos específicos. O parnasianismo, por sua vez, centrava-se numa descrição mais exterior e estética dos negros, contraposta pelo extremismo subjetivista do simbolismo. O regionalismo, sob a forma do conto sertanejo, descrevia os negros de modo um tanto exotizante e idealizado. No modernismo, quando se assume nossa feição de povo mestiço, o negro deixa de

\footnotetext{
212 Jean M. Carvalho França. Op. cit. p. 101-110.

${ }^{213}$ Idem. p. 106 e 107.
} 
constituir-se apenas como tema de poesia, para se tornar inspiração de uma nova lírica. Além disso, não mais representado de modo tão exótico e distante, é descrito para falar de nós mesmos - uma cultura e um povo mestiço.

A literatura infantil, em linhas gerais, surgiu de uma preocupação, de natureza republicana, com a formação das crianças dentro de certos valores morais e conteúdos próprios à nação brasileira. Mas em seu início, ela ainda era marcada por uma transcrição da literatura oral folclórica, ou mesmo por adaptações de livros estrangeiros. Nesse contexto, a mãe-preta surge como contadora de histórias folclóricas em serões; veja-se, por exemplo, o livro de Luiz Demétrio Juvenal Tavares. Olavo Bilac, que trabalhava no campo da educação ensina, por meio da figura de Mãe Maria, uma certa valorização humanitária. Já Oswaldo Orico, também atuante no campo pedagógico, e ligado a um famoso periódico de entretenimento infantil, retoma a mãepreta “contadora de histórias folclóricas”, que desta mesma maneira aparece na obra de Viriato Correia. Por sua vez, Monteiro Lobato, cuja obra é o marco fundador de uma literatura infantil brasileira, criou Tia Nastácia, uma negra velha contadora de histórias folclóricas, além de agregada da família e cozinheira.

A preocupação com a educação e com uma reforma no ensino, empreendida a partir da chegada de Getúlio Vargas ao poder, também influenciou a produção da literatura infantil. Porém, não sem antes passar pelo crivo de uma comissão que avaliava seus conteúdos e formas de transmissão para as crianças. O livro de Ofélia e Narbal Fontes deixava explícito esse tipo de cuidado, procurando veicular numa linguagem acessível valores morais e cívicos, além do folclore das mais variadas regiões do país. Cabia a Quitéria, negra cozinheira da casa, ensinar as crianças acerca das festas típicas de sua terra natal, a Bahia. José Lins do Rego e Luís Jardim compuseram obras aprovadas e premiadas pela Comissão Nacional de Literatura Infantil, nas quais as negras velhas são exímias contadoras de histórias muito bem-quistas pelas crianças.

Os movimentos literários a que pertenciam os literatos que produziram versões da mãepreta inserem-se em diferentes contextos histórico-culturais, que se concentram durante a Primeira República e na Era Vargas. Dessa forma, obra literária e contexto se implicaram mutuamente.

Na Primeira República, havia a preocupação de fazer do Brasil - racialmente mestiço, recém-saído da monarquia e da escravidão - um país “civilizável”. A Monarquia era, então, associada à escravidão, na mesma medida em que a República à civilização. Mas essa civilização era definida por padrões estrangeiros, cosmopolitas e burgueses. Como admitir e repensar essa população brasileira mestiça, analfabeta e de hábitos “popularescos” (e pouco civilizados) como 
formadora de uma nação? É este o embate da intelectualidade daquele momento, ainda muito influenciada pelas teorias racistas “científicas”, que duvidavam da viabilidade desse país mestiço $^{214}$. O enigma era satisfazer a necessidade de formação de uma nação brasileira, mediante uma forte desconfiança de que o povo do Brasil (desconhecido, liminar, mestiço) fosse digno - e capaz - de tal função. Segundo Nicolau Sevcenko, os intelectuais ${ }^{215}$ desse momento chegaram a duas soluções: “A mais simplista consistia em sublimar as dificuldades do presente e transformar a sensação de inferioridade em um mito de superioridade: é a ‘ideologia do país novo’, o ‘gigante adormecido', cujo destino de grandiosidade se cumprirá no futuro. A outra implicaria um mergulho profundo na realidade do país a fim de conhecer-lhe as características, os processos, as tendências (...). Nesse contexto é que se inserem os esforços renitentes despendidos na tentativa de determinar um tipo étnico específico representativo da nacionalidade ou pelo menos simbólico dela, que se prestasse a operar como um eixo sólido que centrasse, dirigisse e organizasse as reflexões desnorteadas sobre a realidade nacional.,216.

Essa geração intelectual, que tenta realizar sua missão por meio da literatura ${ }^{217}$, acaba por se angustiar na tentativa de encaixar ou enquadrar a realidade que tinham diante de si, entre 1890 e 1914 - um povo analfabeto e mestiço - seja nos modelos civilizados almejados pela República, seja nos modelos racialistas ainda em voga.

Estando ciente desses valores de época, convém repensar os movimentos literários, que produziram representações da mãe-preta, contemporâneos a estes ideais. O afastamento entre o escritor branco e o objeto do discurso, presente no parnasianismo e no conto sertanejo, torna-se mais compreensível. No entanto, neste contexto pós-abolição - mas que escamoteava a escravidão e os negros por visar um "Brasil civilizado” -, quais sentidos poderiam ser veiculados pela mãe-preta?

Numa incipiente literatura infantil, ela surgia como uma personagem negra que contava histórias e ajudava a criar os filhos de sua senhora. Era, nessa medida, uma negra "civilizada” próxima e “amiga” da família branca. Mas, por outro lado, era também uma "agente civilizadora”, no sentido de que era responsável por uma certa socialização das crianças.

\footnotetext{
${ }^{214}$ O impasse desses "homens de ciência" (de fins de XIX e início do XX), que importavam as teorias racistas, num país eminente miscigenado, é analisado por Lilia Moritz Schwarcz. Segundo a autora "esses intelectuais irão se mover nos incômodos limites que os modelos lhes deixavam: entre a aceitação das teorias estrangeiras - que condenavam o cruzamento racial - e sua adaptação a um povo a essa altura já muito miscigenado”. Lilia Moritz Schwarcz. O espetáculo das raças. São Paulo, Companhia das Letras, 1993/2000. p. 19.

${ }^{215}$ Essa intelectualidade da Primeira República estudada por Sevcenko incluía: Olavo Bilac, Coelho Neto, Graça Aranha, Cruz e Sousa, Euclides da Cunha e Lima Barreto etc.

${ }^{216}$ Nicolau Sevcenko. Op.cit. p. 106.

${ }^{217}$ A termo "literatura como missão" é de Nicolau Sevcenko.
} 
A mãe-preta presente nos Contos Pátrios para crianças $^{218}$, de Bilac, também é “civilizada” - isto quer dizer, afetivamente próxima da família branca do conto - e ao mesmo tempo civilizadora - ensinando lições de “cunho humanístico”, sobre o significado do amor, da confiança e do bom comportamento. E quando não “civilizadas”, as mães-pretas são, ao menos, boas o suficiente para se sacrificarem pelos seus senhores e pela pátria.

Houve ainda aqueles escritores que compuseram suas obras - nas quais constam representações da mãe-preta - durante a Era Vargas integrando, portanto, uma geração que construiu algumas representações oficiais do Estado Novo. Os símbolos oficiais desse período apropriaram-se de certos desdobramentos da rotinização do modernismo; que havia assumido nossa identidade como povo, marcadamente, mestiço. ${ }^{219}$ Deste modo, tais representações institucionais insistiam na idéia da mestiçagem nacional. "Na verdade, no Brasil dos anos 30, dois grandes núcleos aglutinam conteúdos particulares de nacionalidade: o nacional-popular e sobretudo a mestiçagem, não tanto biológica como cada vez mais cultural. É nesse contexto também que uma série de intelectuais ligados ao poder público passam a pensar políticas culturais que viriam ao encontro de 'uma autêntica identidade brasileira',,220

Neste período são inúmeros os símbolos, antes associados ao povo e aos negros, que emergem como mestiços e nacionais, entre eles: a feijoada, a capoeira, o samba, o candomblé, o malandro, a mulata, a Nossa Senhora da Conceição Aparecida e o futebol. No entanto, essa “elevação simbólica e oficial da raça” - ou dos elementos e das práticas culturais identificados aos negros - não implicou numa mudança imediata no tratamento dessa população, que continuou marginalizada. Desse modo, ainda que publicamente houvesse uma identificação com os símbolos nacionais mestiços - reveladora de uma "alentada convivência cultural miscigenada”221 - no plano privado, um racismo baseado nas teses de "inferioridade dos negros" continuava vigente.

É nesse contexto paradoxal que as representações ambíguas da mãe-preta voltam a ser acionadas. Mãe-preta de filho branco, se não é mestiça, é ao menos produtora de mestiçagem; amamentando as crianças brancas, ou ainda, ao socializá-las por meio de histórias e cuidados. Esse contato íntimo entre a negra e seu filho branco, promoveu uma mistura de "raças”, cores,

\footnotetext{
${ }^{218}$ Olavo Bilac e Coelho Neto. Op. cit.

${ }^{219}$ Há de se ressaltar que esse reconhecimento “positivo” do povo brasileiro, como sendo mestiço, só foi possível mediante a mudança do paradigma racial, pelo cultural. Gilberto Freyre, em sua obra Casa-Grande \& Senzala catalisou essa passagem de perspectivas. Para uma análise mais detida deste fato vide, entre outros: Lilia Moritz Schwarcz. O espetáculo das raças. Op. cit. 1993/2000.

${ }^{220}$ Lilia Moritz Schwarcz. "Nem preto nem branco, muito pelo contrário: cor e raça na intimidade”. in: Lilia Moritz Schwarcz (org.) História da vida privada no Brasil- volume 4. São Paulo, Companhia das Letras, 1998/2006. p. 193.
} 
afetos e culturas. Assim, a ambígua mãe-preta promove a mestiçagem em suas duas acepções: na "biológica”, por meio do leite, e na cultural, por meio dos cuidados de mãe e das histórias folclóricas. E, nessa acepção, ela pode ser considerada como ser "híbrido”, estando ao mesmo tempo no campo da natureza como no da cultura. ${ }^{222}$

Mas foi no campo da literatura infantil que a mãe-preta apareceu, de certo modo, ligada à construção conjunta de uma identidade nacional. As obras que a tomavam como um repositório de histórias folclóricas, além de exímia narradora, foram aprovadas e premiadas pela Comissão Nacional de Literatura Infantil, criada em 1936, pelo governo Vargas.

Talvez, esses contextos literários e histórico-culturais expliquem alguns dos sentidos ambíguos da mãe-preta, mas eles são inócuos diante da permanência dessa figura por tanto tempo no imaginário brasileiro. Essa dissertação procura tratar exatamente disso.

Passo agora à analise dessas obras literárias e ao levantamento de algumas representações recorrentes da mãe-preta, por vezes afinadas, por vezes contraditórias entre si. Trata-se, de algum modo, da espetacularização da ambigüidade.

Antes de empreender tal exercício interpretativo convém fazer mais uma ressalva.

A partir da década de 1950, as representações literárias da mãe-preta começam a ficar mais rarefeitas, o que dificulta uma compreensão de tais figuras dentro de algum movimento literário delimitado. Soma-se a tal constatação, o fato de seus autores contemporâneos serem progressivamente “obscuros”, o que constitui mais um empecilho à compreensão e análise desse conjunto de obras. Além do mais, o conteúdo do material torna-se progressivamente repetitivo, não fazendo jus à sua inclusão.

No entanto, há um conjunto de obras, dotadas de uma certa homogeneidade, que traz representações da mãe-preta, e que preferi não analisar: as memórias. Dentre elas há aquelas que têm como autores os antigos senhores de engenho, como Minhas Recordações ${ }^{223}$ e O velho Felix e suas 'Memórias de um Cavalcanti' ${ }^{224}$, ou ainda o relato da infância nos sobrados e casasgrandes que estão presentes em No Tempo de Dantes $^{225}$ e Velhos engenhos de minha terra ${ }^{226}$, ou

\footnotetext{
${ }^{221}$ Idem. p. 201.

222 Essa definição de "híbrido", como fazendo a mediação entre a natureza e a cultura é de Bruno Latour. Vide: Bruno Latour. Jamais Fomos Modernos. São Paulo, Editora 34, 1994.

${ }^{223}$ Francisco de Paula Ferreira Rezende. Minhas Recordações. Rio de Janeiro, José Olimpio, 1944.

${ }^{224}$ Gilberto Freyre. O velho Felix e suas 'Memórias de um Cavalcanti'. Recife, Editora Massangana, 1989.

${ }^{225}$ Maria Paes de Barros. No tempo de dantes. São Paulo, Paz e Terra, 1998.

${ }^{226}$ Andréa Godim Fernandes. Velhos engenhos de minha terra. Recife, Editora Asa, 1986.
} 
mesmo as memórias de infância, entre as quais $O$ meu pequeno mundo de Luís Jardim²7 e Meus Verdes Anos de José Lins do Rego ${ }^{228}$. Essas obras, contudo, surgiram tardiamente - em fins da década de 1940 -, e sua produção se estendeu por um dilatado espaço de tempo, até o final da década de 1980. Elas, portanto, não se adequavam ao recorte das fontes escolhido nesta dissertação, que abrange as representações da mãe-preta realizadas nos fins da escravidão até meados de 1950, quando se consolida uma memória sobre tal figura.

${ }^{227}$ Luís Jardim. O meu pequeno mundo. Rio de Janeiro, Livraria José Olympio Editora, 1976.

${ }^{228}$ José Lins do Rego. Meus Verdes Anos. Rio de Janeiro, Editora Nova Aguilar S.A., 1987. 


\section{Parte II}

Capítulo 3

Representações da mãe-preta: delineamento e contrastes

Capítulo 4 Diversos sentidos da mãe-preta na literatura infantil brasileira 


\section{CAPÍTULO 3}

\section{Representações da mãe-preta: delineamento e contrastes}

\section{Introdução}

Como já deve estar ficando claro, são muitas as representações da mãe-preta. Elas ora são definidas como “amas-de-leite”, ora como “amas secas”, ou ainda como “mucamas” ou “mães de criação”. Em outros textos, são “mães escravas”, “agregadas”, “negras velhas”, “cozinheiras” ou “contadoras de histórias”. Diante dessa profusão de sentidos, como ordená-los de modo a conseguir relacionar alguns significados recorrentes?

Genericamente, mãe-preta se refere a personagens remanescentes da escravidão, sobretudo mulheres relacionadas ao universo da escravidão doméstica e que são, portanto, muito íntimas e bem quistas pelas crianças brancas, das quais cuidam e, principalmente, para quem contam suas histórias. Mas em diferentes contextos históricos, e mesmo literários, certas características são mais enfatizadas do que outras.

O próprio termo mãe-preta já aponta para significados diversos construídos por contraposição. Primeiramente, mãe-preta implica na contrapartida oposta e complementar, filhobranco (os pares complementares e opostos seriam mãe/filho e preta/branca). Além disso, essa maternidade - que tem como qualificativo o termo "preta" - evidencia a existência de uma outra maternidade "branca”. E, por existir uma mãe-preta, há de se questionar sobre a existência de um filho igualmente preto. Mas havendo filho-preto, quem é seu pai? E ele é preto ou branco? Ou ainda, existiria o homólogo masculino da mãe-preta; um pai-preto?

Essas relações estruturais, que o termo mãe-preta evoca, também estão presentes como se verá, nas fontes. ${ }^{229}$

\section{Mãe-preta de filho-branco}

Central e definidora da categoria mãe-preta é sua relação com o filho branco: as fontes que tratam desse vínculo social versam, principalmente, sobre as funções realizadas de modo especial pela personagem para com seu “filho". Normalmente, é a maneira particular - em meio a muito carinho e afetuosidade - com que realiza tais obrigações, que lhe garantem, por sua vez, o qualificativo de parentesco afetivo presente no termo “mãe”. Às vezes, mãe-preta protege seus

\footnotetext{
${ }^{229}$ Nessa parte do trabalho selecionei algumas dentre as variadas fontes que recolhi. A seleção feita procura destacar algumas personagens mais recorrentes e, para tal, agencio fontes nacionalmente representativas, e que abranjam diferentes gêneros. No entanto há, em anexo, uma transcrição mais completa de todas as fontes que compilei.
} 
filhos brancos das repreensões de seus próprios pais naturais. A história de mãe Maria, contada por Olavo Bilac ${ }^{230}$ é paradigmática quanto a esses aspectos:

"Mãe Maria

É ainda esta, no fim de minha longa vida, tão cheia de alegrias e tristezas, a recordação mais funda que guardo dentro da alma.

Fechando os olhos, para mais claramente evocar a memória dos dias da minha infancia, vejo logo, nitidamente desenhada pela minha saudade, a doce figura da velha Mãe Maria. Tão velha!... Quando nasci, já o seu cabello encarapinhado embranquecia. Ainda viveo comigo uns treze annos."

O narrador, ex-filho-branco de mãe Maria, inicia o conto mostrando qual é o sentimento que nutria por essa figura que tanto lhe marcou a infância, assim como recupera suas características mais marcantes: “doçura”, “velhice” e o “cabelo encarapinhado” a embranquecer. Em seguida, explicita as razões do porquê era lembrada com tanto carinho e chamada de “mãe”:

“Assim, a velha Maria foi a minha verdadeira mãe. (...) - Boa mãe Maria! Era ella quem me lavava, quem me vestia, que me aturava... Quando eu não queria obedecer, procurava fingir se zangada, e ameaçavame: «Nhô Amancio! Nhô Amancio!» E acalmava-me, por fim, promettendome uma nova historia. Sentava-se no chão cruzava as pernas, e começava. Ouvia-se apenas na sala o resonar de meu pae que dormia a sésta, o pigarro da velha prima que cosia, o ruído que faziam os ferros de engommar sobre as táboas, e a voz arrastada de mãe Maria, falando de saciperêrês, de caipóras, de almas do outro mundo e de anjos do Senhor.

Todo aquelle enredo fantástico, em que passavam bruxas cavalgando cabos de vassouras, principes que roubavam princezas, archanjos que desciam do céo para curar as feridas dos escravos no tronco, negras aleijadas, que invocavam o diabo, à meia noite, no meio do matto, e eram afinal arrebatadas por elle, numa nuvem de fogo e enxofre - tudo aquillo se atropellava na minha cabeça, cançando-me, dando-me arrepios e vertigens de medo.

D'ahi a meia hora, pesavam-me as palpebras. Aos meus ouvidos, a voz de Maria chegava cada vez mais fraca: até que quase sumida de todo, parecia vir de longe, de muito longe, vaga e indistincta como um echo. Eu deixava caír a cabeça sobre o seu collo, e dormia. E era ella quem, carinhosamente, me levava para a cama, era ella quem me despia e, obrigando-me a ficar de joelhos, tonto de somno, me fazia repetir o Padre Nosso, estropiado pela sua língua de africana."

Nhô Amâncio fala que a velha Maria foi "sua verdadeira mãe”, justificando que ela teria cumprido com a mesma "verdade”, “carinho” e competência um cargo que originalmente não seria dela. Sua mãe natural era paralítica e doente, de modo que desde a mais tenra infância fora a ama Maria quem cuidara dele. Esse cuidado incluía os banhos, atenção com o vestuário, ninar a

\footnotetext{
${ }^{230}$ Olavo Bilac e Coelho Neto. Contos Pátrios para creanças. Rio de Janeiro, Francisco Alves \& Cia, 1894/1918, $16^{a}$ edição. p. 15-30. Para as fontes mantenho sempre a grafia original. Além disso, há uma transcrição mais completa de todas as fontes citadas em anexo.
} 
criança em seu colo, acalmá-la com histórias, além de ensiná-la a rezar. Havia, desse modo, uma certa socialização envolvida no trato da mãe-preta para com seu filho branco. Nesse relacionamento, ocorria também uma profunda troca afetiva, que fica expressa no tom saudosista e emocionado do narrador, Amâncio. Desse modo, ainda que não fosse sua mãe biológica ou mãe legítima pertencente à família branca, Maria desempenhava para o garoto, um papel materno definido pela amamentação, pela vigília de seu sono, pela "paciência carinhosa” com que tratava suas birras, pelos ensinamentos religiosos e, principalmente, pelo afeto que nutriam um pelo outro. Ser mãe tal qual a “mãe Maria” implicava em certa natureza - inscrita no aleitamento - e em certa cultura - expressa pelos incontáveis cuidados para com o menino. A própria "mãe Maria”, “africana”, reconhece Nhô Amâncio como "filho”, quando é obrigada a despedir-se dele - estando ambos aos prantos - para a ida do menino ao colégio interno:

“Ella chorava também, chamando-me seu filho, beijando-me, consolandome:

- Vae, Nhô Amâncio! vae, meu filho! vae p'ra ser homem! vae, Nhô Amâncio! a sua negra velha fica resando a Nosso Senhor! a velha fica resando!"

Mãe Maria alterna o uso do termo “filho” com o de "Nhô”, diminutivo terno para o pronome de tratamento "senhor". Ainda que matizado pela afetividade, o uso de "nhô" revela a hierarquia social existente entre os pólos dessa relação de amor: escrava negra e filho da família branca a quem ela servia.

Também emocionada pela despedida, “mãe Maria”, numa atitude tipicamente materna, incentiva "seu filho” a partir para se tornar homem. Resignar-se-ia a rezar por ele. "Mãe Maria” que era “negra velha”, mas também “africana”, é descrita como extremamente religiosa - rezava por Nhô Amâncio - além tê-lo ensinado o "Padre Nosso" na infância. A personagem de "mãe Maria”, ainda que “africana”, não era um “outro”, ou uma “negra bárbara”. Era “civilizada”, no sentido de que tinha hábitos e características próximos aos dos brancos: era católica, amável, bondosa, limpa e conhecedora de histórias. E justamente a transmissão de tais valores a "Nhô Amâncio” que faz dela um "agente civilizador”.

Sem criança para cuidar, a escrava fora remanejada para outros serviços domésticos, principalmente o de lavadeira. Nhô Amâncio vai para o colégio e, nos primeiros meses, sente muitas saudades de Maria, principalmente de seu cabelo “encarapinhado” e de sua voz sempre “doce”, a contar histórias. Contudo, à medida que faz novas amizades e se interessa pelo mundo que lhe vinha sendo apresentado pela escola, a memória da negra velha vai lhe parecendo cada 
vez mais distante e infantil, uma vez que ele se transformava em "sinhô-moço". Quando volta de férias para a casa do pai, “mãe Maria” lhe recebe efusiva:

“- Ah! Nhô Amâncio! - dizia a preta chorando, de joelhos, beijandome as mãos - como Nhô Amâncio está crescido e bonito!"

Nhô Amâncio julga-se crescido para manter o mesmo tipo de relação com a ama, ainda que ela continue a nutrir-lhe o mesmo tipo de cuidados e carinhos. Ele, se considerando um “maduro senhor-moço”, não lhe dá mais a antiga atenção, preferindo fazer ginástica a escutar as histórias (agora consideradas atrapalhadas e tolas) de "mãe Maria”. Para provocá-la, o menino travesso desce ao quintal e atira pedras nas galinhas. A negra, que estava corando as roupas entre o garoto e o galinheiro, protestou:

“- Nhô Amâncio! Nhô Amâncio! que maldade menino! deixa os bichos, Nhô Amancio»

— «Nhô Amâncio! Nhô Amâncio! Deus castiga, Nhô Amâncio! Nhô Amâncio» - repetia a preta, mas sem gritar, receando que meu pae a ouvisse. E eu ria, e continuava. Correo então para mim... Eu ria. E as pedras passavam por ella, rentes algumas, na direção dos cercados."

No entanto, o menino, como a desafiar-lhe, continuava com sua troça, até que feriu sua velha ama na cabeça. Ao vê-la machucada por suas próprias mãos, Nhô Amâncio se desespera e retorna-lhe ao peito todo aquele afeto que negligenciara desde a volta da escola. Busca por socorro, mas é repreendido pela negra, pois chamaria a atenção de seu pai. Quando este chega, o menino teme pelo castigo; mas sua "mãe", num ato de "extrema indulgência”, reinventa o ocorrido, colocando "seu filho" no lugar do herói, para que não fosse repreendido. Para tal, responde da seguinte maneira ao seu patrão, o “pai severo” de Amâncio:

“- Não foi nada, Sinhô, não foi nada! A negra velha escorregou no sabão, e quebrou a cabeça nas pedras. Mas Nhô Amâncio acudiu logo. Não foi nada Sinhô, não foi nada!"

Esse ato da “mãe de criação” faz com que seu "filho branco" lhe reafirmasse todo o amor:

“(...) caí nos seus braços pedindo-lhe perdão, cobrindo de beijos aquella face que me parecia tão bella, tão clara, tão iluminada, como a face de um daqueles anjos do Senhor, de que ella me falava nas suas compridas historias da roça. E ella, chorando tambem:

«Que é isso, Nhô Amâncio? Que foi que mãe Maria fez?... tinha que ver que Nhô Amâncio fosse apanhar uma sova por causa do cangalho de uma negra velha!...»"

Depois dessa atitude indulgente de “mãe Maria”, ela é descrita como "tão bella, tão clara, tão iluminada, como a face de um daqueles anjos do Senhor, de que ella me falava nas suas compridas historias da roça”. Objeto do amor do menino, por quem se sacrificava num ato de 
verdadeiro amor de mãe, "mãe Maria” se santifica, sendo comparada aos anjos do senhor; e nesse mesmo processo, ela também branqueia, passando a ter “faces claras e iluminadas”. Deste modo, sendo muito querida por seu filho branco, e capaz de gestos heróicos, além de altamente honrados, “mãe Maria” se aproxima ainda mais do perfil da família branca e “civilizada”. No entanto, apesar de ser tomada afetivamente como membro da família, isso não impede que Maria seja vendida após a morte de seu senhor.

“D'ahi a um anno, quando de novo voltei ao collegio, ainda, abracei mãe Maria. Vi-a e abracei-a ainda, pelo Natal dois annos seguidos. Depois... morto meu pae, morta minha Mãe, vendido todos os escravos da casa, - nunca tive quem me disesse onde foi dormir o seu ultimo somno a minha velha mãe Maria, alquebrada por quasi um século de captiveiro e trabalho."

Esses imponderáveis da escravidão acabam por tornar o Amâncio-adulto uma pessoa culpada, por não saber onde fora enterrada sua "verdadeira mãe” afetiva, que era também sua escrava, de “corpo alquebrado por um século de cativeiro”, parte considerável desses anos a seu serviço. Como se vê, trata-se de uma relação no mínimo paradoxal: o afeto não leva à liberdade; mas, às vezes, ao seu contrário.

Em um outro conto, de Cornélio Pires ${ }^{231}$, é possível acompanhar a construção de outra relação de "maternidade” entre ama escrava e sinhozinho branco. Em, “Tará Bão de Sá?...” (título do texto), quem está contando a história é “Tia Jacinta”, a própria ama, e seu interlocutor é o sobrinho de seu filho branco "Nho Dô”. Sua fala é grafada pelo autor regionalista, levando em conta sua entonação, trejeitos e sotaques. Nesta passagem, ela narra como foi comprada e escolhida para a função de ama:

“Um dia, graás a Deus e nosso Nossinhô Jezuis Cristo, pareceu seu avô. Sua mãe inda num era casada... Era ua moça tão bunita... suas tia, meas sinhá moça, seus tiu... Seu avô tava percizando de ua maman p'ra seu tio Nho Dô, que tinha nascido; eu tava cum leite de meis... meu marido tinha sido vendido p'runs home da província de Mina... Eles cunversaro; Sinhá chamô eu:

- Jacinta!

- Sinhá! E vim lá da cuzinha.

- Vassuncristo, Sinhô! Lovado seja nossinhô Jezuis Cristo...

- Deus te abençoe.

- Amen Jezuis.

Quim.

- Óia, negra... póde pegá seu fio... Vendí ocê c'o criolinho p'ra nhô

Cumpanhei seu avô.

Quando cheguei, sua avó me inzaminô, vê se eu num tinha firida, se eu era forte, cherô mea boca p'ra vê se eu não bebia pinga... e ficô

${ }^{231}$ Cornélio Pires. Quem conta um conto... E outros contos (coisas de outrora). São Paulo, Livraria Liberdade, 1915/1943. p. 158-165 
contente. Fiquei durmindo em casa e o meu fio durmia na merma cama, ua cama maciu, limpa, c'o meu fio de leite, seu tiu. Eu era tratada cum leite, carne, áua de assuca... E Nhô Dô ia cresceno c'o meu fio... Era ua buniteza. Criei os dois e fiquei negra de cuzinha e p'ra serviço casêro; argua vêiz eu mandava inté in Sinhá... Quirium tão bem eu... Vestia as moça suas tia... Lavava os pé de todos..."

“Tia Jacinta”, porque estava com leite recente, em função do nascimento de seu filho natural, foi comprada para exercer a função de “maman”, termo usado aqui como equivalente de ama-de-leite. Nesse contexto, amamentar relaciona-se a um certo vínculo de maternidade. Seguindo essa lógica, “Tia Jacinta” tem um “fio”, natural, nascido de seu ventre e que ela também amamenta; e um outro, "fio de leite”, que é filho somente porque foi alimentado no seu peito e com seu leite.

No entanto, o título de "maman” e o status de ascendência afetiva adquirido junto à família de "Nho Dô" foi mantido mesmo depois que seu "filho de leite” já estava grande e desmamado. “Tia Jacinta” ocupa, então, outras funções dentro da casa-grande; por vezes a cozinha, por vezes a organização da casa. Mas, ainda que "Nho Dô" estivesse crescido, ela continuava a cuidar dele:

“Bão tempo Bão tempo!

Nhô Dô já tava grandinho... De noite eu fazia pelote pr'ele passarinhá cum bodoque no laranja... Eu fazia pelote, ia pono perto do fogo, na cinza, e ia contano história... Quano eu via o povrezinho tava durmino c'a cabeça no meu colo."

O zelo para com seu “filho de leite” implicava em niná-lo com histórias e auxiliá-lo em suas brincadeiras de criança; e tudo isso alegrava muito a negra, que é descrita como "feliz" junto da família em que servira de ama. Aqui, novamente, a figura da ama - tal como a da mãe pertence, simultaneamente, ao mundo da natureza (pela amamentação) e da cultura (pelos cuidados dispensados ao seu filho).

Entretanto, ainda que tudo corresse bem na história, em função da falência de seu senhor, pai de “Nho Dô”, “Tia Jacinta” é entregue como pagamento de dívida para um vizinho, chamado “capitão Fidele”:

“Ele ê-vê que tava deveno pr'um vizinho, um marvado, um tar capitão Fidele, um hóme ruim. (...) Ele tinha ua reiva de mim, morde me vê $\mathrm{p}^{\prime}$ ra sala lidano c'as criança.

- Ah! Negra! Fosse minha!

- Sinhô se atrapaiô de ua veis c'ua jada e...

(...)

- Capitão Fidele chego um dia tudo cheio de si e aperto sinhô por dois conto...

- Quero a negra Jacinta, sem o filho, e está decidido. 
- Não é possível, Capitão! Escolha dois, três, quantos quiser, menos a Jacinta: é a maman de meu filho...

- Intão vamo vê com o merinho.

- Eu vô, sinhô... Graças a Deus meu fio fica...

- Quéto, negra! Ocê há de sê minha p'ra não sê vadia!

Num teve geito: fui dada por pagamento. Tudo chorava quando eu saí: sua vó teve um ataque, sua mãe e suas tia chorarum; Nhô Dô garrôna mea saia e dava ponta-pé no Capitão, chorano... inté Sinhô garro ingulí in seco e foi simbora p' ra drento pendê-pendeno...

(...)

O Capitão não me dexava nem vê meu fio... O feito era um caboclo de cabelo espetado, avô do Tonico, perfeito hoje de Câimbra, mau cumoquê. Um dia eu tava na roça... Me botaro na inxada! Quando Nhô Dô e meu fio - o sítio era pegado - parecero lá tudo sustadinho, chorano p'ra me vê... O feitô veio e zele correro... Derdaí, povre de mim! panhava tudo o dia e me amarraro u alavanca na perna, cuc corrente, cumo se eu fosse negra fugida."

Mesmo que Jacinta vivesse tão bem e fosse muito estimada dentro da casa do senhor sendo considerada literalmente como “quase da família”, já que era mãe de certo quilate (de leite) de um dos filhos da família -, quando seu senhor empobrece, sua condição de escrava é que volta a prevalecer. Ainda que seu senhor tente protegê-la, oferecendo outros escravos no lugar da “maman de seu filho”, o "cruel Fidele” faz valer sua escolha; com o objetivo de deixar claro para Jacinta e a seus permissivos vizinhos como os escravos “devem ser tratados”. Desse modo, “capitão Fidele” faz efetivar a condição de escrava de Jacinta, que estava borrada pelos "laços de leite” e pela intimidade com a família de seu ex-senhor.

Nessa passagem, nota-se como no conto a figura da ama-de-leite não é apenas uma representação da boa convivência com seu filho branco. O sistema escravocrata, e sua violência, aparecem como condição incontornável - promoveu Jacinta àquele lugar de “maman”, uma vez que a negra fora comprada. E nesse papel, ela havia conquistado o afeto da família senhorial. Ela, assim, tem tudo para ser da família, mas não o é. Como se vê, durante a crise financeira, ainda que não queiram, seus patrões são obrigados a vendê-la, e novamente a escravidão se faz presente.

A ama negra não ultrapassa, portanto, o estágio do “como se fosse da família”, porque esse lugar foi conquistado mediante a escravidão, tratando-se sempre de uma incorporação de segunda ordem junto à família patriarcal.

Mas, ainda que a ama sofra castigos e seja muito machucada, ela não é descrita como vítima. Ao contrário, é num ato de coragem, e de "sacrifício" em nome de seus "bondosos senhores” (pais naturais de seu "filho de leite”), que ela concorda em ser vendida para o "vizinho cruel”. E, como toda heroína sacrificada, ela sente as conseqüências de seu ato de bravura: 
trabalha na lavoura, é proibida de ver seus dois filhos, toma "reiadas" e tem de usar ferros de “negra fugida”.

Esse sacrifício não foi, contudo, feito em vão. Seu “filho de leite” não se conforma com o destino de sua tão querida “maman” e, numa retribuição pelo ato de bravura da ama, dá um jeito de ajudá-la a fugir de seu "violento algoz":

“(...)

- Nhô Dô me viu ua veis, quano ia passarinhano, que eu ia cumpanhada do feitô c' oa lavanca arrastano... Ah! Nhô Dô, meu fio branco que me sarvô!

Um dia eu tava carpino minduim na roça, perto do mato virge... Os ôtro tavum num taião bem longe... eu tava sozinha c'o peso nos pé... Nhô Dô saiu abaxadinho do mato e me deu ua lima grande de treis-quina... limei, limei, limei... suor tava correno... eu tava tremeno... Mandei Nhô Dô simbora... Quano eu vi tava sorta, apareceno as firida na perna... continuou:

E ainda como que assustada, num crescendo impressionante,

- Garrei o mato... achei Nhô Dô no carreado... Carreguei ele... saí correno e mancano... Quando Sinhô seu avô e as famía me viu, foi um baruião... eu tava magra... magra!

- Pobre tia Jacinta!

- A pobre!

- Façamo-la fugir...

- Como?

- Espere...

Sinhá troxe ua rôpa véia de sinhô... Vistí ligero... truxero o cavalo lazão... botei um chapéu de paia... Sinhô me deu um pape e grito:

- P'ra Campinas... Procure Antonho Bento!

O lazão levanto puêra na estrada que ia p'ra Campina... Cheguei assustada: fui na chácra do santo Antonho Bento... Ele fico c' o alimá e me mando p'ra Santo... Júlio Moriço me escondeu, e ansim eu fui trabaiano inté comprá mea liberdade. Fiquei forra. Sinhô seu avô num me forrô por não podê... E inté hoje eu moro cum mecêis... mecêis são meus fio..."

A família de seu "filho branco" - termo usado como sinônimo de "filho de leite" também age de maneira honrada com “Tia Jacinta”. Como se reconhecessem sua generosidade, auxiliam-na a fugir para que, mediante seu próprio trabalho, consiga comprar sua liberdade. Desse modo, “Nho Dô” e sua família aparecem na história como dotados de dignidade; isto é, arriscando-se a salvar Jacinta do jugo a que ela também estava submetida quando trabalhava em sua própria casa. Ainda que aí - na casa de seu "filho branco" -, a escravidão não parecesse pesar tanto, já que ela era uma negra de trabalhos domésticos, e relativamente bem tratada.

Nessa história para crianças, atrelada à rede de negociação e favores inerente ao sistema escravista, os laços afetivos de Jacinta com seus ex-senhores fazem com que ela consiga a liberdade, ainda que tenha trabalhado por ela. Desse modo, a negra revela gratidão aos seus antigos senhores bondosos, que a auxiliaram nessa empreitada pela manumissão, passando a 
viver como agregada da família deles. E, nessa condição, ela chama de “filho" todos os descendentes desta família. No conto, a liberdade de Jacinta, ainda que a escrava tenha trabalhado por ela, é entendida como dádiva dos "bondosos senhores” e não como conquista da própria negra. Nessa medida, são os senhores que recebem os louros por sua "generosidade” e “benevolência”, ainda que a manumissão da negra tenha sido resultado de um resgate, em que ela própria pagara o seu valor. Uma dádiva de tal magnitude implica sempre em contrapartida; de modo que, a escrava agradecida permanece fiel a seus ex-senhores indulgentes, morando com eles e sua família. ${ }^{232}$

Com tantos anos de convivência próxima e íntima, a própria “Tia Jacinta” se inclui no parentesco da família branca, empregando o termo "filhos" a todos os descendentes de seus antigos donos. Eles respondem a tal tratamento, chamando-a por "Tia Jacinta”, palavras que também implicam no reconhecimento de certo “parentesco afetivo”.

Assim, insisto, novamente: “Tia Jacinta” é íntima, é próxima e “é negra; mas é quase da família”. Há, portanto, uma ligação profunda, e de troca afetiva - no limite, uma certa mistura entre os senhores brancos e “Tia Jacinta”. Contudo, diante dessa impressionante proximidade quiçá ameaçadora - se reinstala a diferença. Essa fica expressa na linguagem "africanizada”, “tipicamente” de escrava, com que Jacinta se exprime. Jacinta é quase uma igual, mas sempre diferente.

Outro conto, “Deus Perdoa”, de Cornélio Pires, localizado no mesmo livro, Quem conta um conto... E outros contos (coisas de outrora) ${ }^{233}$, tem como protagonista outra "maman" “extremada” e "incansável” no trato com seus filhos brancos. O narrador descreve a ama do seguinte modo:

"A negra velha, carinhosa e dedicada, é, às vezes, mais solícita no tratamento das crianças que as próprias mães. Quanto amor, quanta dedicação naqueles frangalhos de gente! Raça alguma tem produzido mais adoraveis 'mamans'. Sofrem, se sofremos; gozam, se gozamos. Têm sempre palavras de conforto para os ex-senhores empobrecidos, e para os 'sinhôs-moços' extravagantes e repreendidos pelos 'velhos'."

A “maman” já surge comparada às mães naturais das crianças, já que ela é uma outra espécie de mãe; por vezes considerada até mesmo melhor que as "verdadeiras”. Essa vantagem seria conquistada por meio de uma dedicação sem limites aos seus “filhos de leite”. Elas

\footnotetext{
${ }^{232}$ Há vários estudos que analisam o "caráter dadivoso” tanto da manumissão, quanto da abolição da escravatura. Indico dois deles: Manuela Carneiro da Cunha. "Sobre os silêncios da lei: lei costumeira e positiva nas alforrias de escravos no Brasil do século XIX” in: Manuela Carneiro da Cunha. Antropologia do Brasil. São Paulo, Brasiliense, 1987. Robert Daibert Junior. Isabel a "Redentora" dos escravos. Bauru, Edusc, 2004.

${ }^{233}$ Cornélio Pires. Op. cit. p. 276-280.
} 
chegariam mesmo a compartilhar daquilo que eles sentem - sofrimento ou felicidade -, e estariam sempre dispostas a consolar seus pequenos e seus senhores. Esse ser absolutamente abnegado é corporificado na figura da uma "negra velha”, um "frangalho de gente” de tão acabada, e que pertence a uma "raça” que produz “mamans” incomparáveis. É a "negritude” (ou a ascendência africana) que parece também justificar a excelência dessas mulheres como “mamans”. A vocação para a maternidade, nessa medida, estaria em “sua natureza”.

No desenrolar desta história, a doação da negra velha para com seus dois filhos brancos era tanta, que durante uma epidemia de febre amarela na cidade de Campinas, ela não parte em quarentena, servido-lhes de enfermeira; ainda que sua própria saúde estivesse em risco.

"A febre colhêra, de surpresa, dois moços da nata campineira.

'Mãe-Preta' preferiria morrer queimada viva a abandonar os 'sinhôsmoços'.

Carlos e Nhonhô, na própria casa fidalga e cheia de conforto, eram tratados pelos melhores médicos, sob as vistas da preta-velha, incansavel enfermeira, que sabia resistir ao sono, não despregando do quarto dos doentes.

Quantas vezes, com cuidado extremo, tivera de levantar os doentes, na cama, amparando-os, para que não se afogassem com o vômito, na fraqueza que estavam!

Quantas vezes, ao sentí-los dormindo, se ajoelhara a um canto, rezando rezas fervorosas, rogando a salvação para seus filhos de leite!

No período mais forte da moléstia, 'Mãe-Preta' ergueu os olhos para - céu e fez uma promessa para que seus ricos patrõezinhos não morressem;

- Ai, meu Deus! Jezuis, Maria Jusé, c'oa graça do Divino Esp'rito Santo! Sarvai Nhonhô Taliba e Nhô Carro e eles hão d'i inté o çumitério, andano, cheio de grão de mio drento das butina! Sacrifício in agradecimento da sarvação por vóis!"

“Mãe-Preta”, nome da personagem que fora ama-de-leite dos "sinhôs-moços” - Carlos e Taliba - exercia uma função materna, ao zelar pelos seus filhos de criação enfermos, auxiliando os médicos, velando o sono, amparando-os na fraqueza. Um sentimento materno também se expressa na preocupação que ela tem pela cura dos rapazes. Com medo de que não se salvassem, “Mãe-Preta” novamente é descrita como sendo muito religiosa: “reza fervorosamente”, e faz promessas para a cura dos jovens.

A história continua, anunciando a melhora dos rebentos, e "Mãe-Preta” agradece a Deus pelo milagre recebido. Procura seus filhos de leite para contar-lhes sobre a promessa que lhes havia curado, de modo a convencê-los a cumpri-la:

“Agora eu vô contá p'ra vassunceis: quano tavum muito ruim, eu fiz ua promessa e lógo miorarum...

- Uma promessa?

- E é perciso cumprí...

- Mas não prometemos nada! 
- Mais eu fiz a promessa e meceis hão de cumprí, sinão Deus me castiga, póvre da negra véia...

- Mas qual foi a promessa, Mãe Preta?

- Dos dois irem daquí inté no çumitério, cum mio por drento na sola das butina, sem meia, andano...

- Livra!

- É melhor atendermos, Nhonhô... Satisfaremos a vontade da nossa boa

'Maman'...

- É issomêmo.

- Pois que seja!"

Os rapazes descritos como "boêmios” e “folgazões”, mas com "boa alma” e "nobres corações”, titubeiam em cumprir a promessa feita por sua Mãe-Preta para que ficassem curados. A “maman” alega que sofreria castigos divinos, caso seus filhos não cumprissem o prometido. Assim, para contentarem sua “querida” "Mãe-Preta”, poupando-a também de tais punições, por reconhecimento à sua dedicação constante, os jovens se dispõem a cumprir a promessa. A precedência afetiva da “Mãe-Preta” e sua abnegação em servi-los é que os obriga moralmente, portanto, à contraprestação divina. O ato honrado e heróico da ama teve retribuição de seus filhos brancos, que fizeram o que ela lhes pedira. Assim, senhores brancos e "maman” negra estão atados por um “vínculo moral”; numa posição de igualdade: ambos dignos e nobres. Há certa equidade moral entre os filhos brancos e a mãe-preta. Mas essa parecença implica num imediato reconhecimento da diferença, novamente evocada na fala de "preta-velha” e de “escrava” da “maman”.

Outra ambigüidade presente nessa “maman” negra (mas de moral branca) diz respeito à sua religiosidade. Ela seria católica, referindo-se a "Deus”, “Jezuis”, “Maria Jusé” e ao "Divino Esp’rito Santo”. Porém, a penitência, que implicava uma ida ao cemitério (com milho nas botinas), dá pistas acerca de um catolicismo se não popular; muito permeado pela idéia de magia, cuja origem não seria exatamente "branca”.

Também, Luiz Demétrio Juvenal Tavares, no prólogo de seu livro infantil ${ }^{234}$, apresenta a figura da "Mãe Preta”, como sendo a personagem principal e narradora do livro. Ela é descrita do seguinte modo:

“(...)

Havia (...) outra autoridade no estudo doméstico, igualmente respeitável, que partilhava com ela [com a mãe tinga/branca] esse poder: - era a 'mãe preta', ordinariamente uma mulata velha, séria e bondosa, que tinha a grave incumbência de criar todos os meninos da 'sinhára'.

\footnotetext{
${ }^{234}$ Luiz Demétrio Juvenal Tavares. Serões da Mãe Preta. Belém, Secretaria de Estado da Cultura/Fundação Cultural do Pará Tancredo Neves, 1890/1990. p. 93.
} 
Oh! quantas recordações docemente saudosas, não nos traz este ente querido, em cujo 'colo' íamos para o banho, a cuja narração de historietas inverossímeis passávamos as horas agradáveis do serão, a cuja voz, cantando o 'ninã-ninã' ou o 'murucutu empresta o teu sono', adormecíamos em nossa redinha de fio de algodão!...

A 'mãe preta' tomava a si o cuidado especial e carinhoso de dar aos meninos todo o bom tratamento que Ihes convinha, asseiando-os com especial dedicação.

À noite, rodeada das crianças, embaixo de uma grande candeia de barro alimentada com azeite de andiroba, ela Ihes contava alegres e divertidas histórias.

Se fossemos poeta de gênio, em vez desta singela notícia, consagraríamos um poema a essa personalidade da 'mãe preta', cuja imagem sempre querida, guardamos no peito, cuja recordação perdura em nossa memória, em traços indeléveis."

O saudosismo e a admiração do autor pela "mãe preta” ficam evidentes na maneira como ela a elogia: "imagem querida e guardada no peito". Ele a exalta, ainda, ao mencionar que se sentia incapaz de prestar uma homenagem adequada a ela: seria digna de um poema, muito mais do que de uma "nota explicativa”.

A figura da "mãe preta” é, outras vezes, enaltecida por Tavares; quando a descreve como “autoridade no estudo doméstico”. Autoridade pode ser entendida na chave de associação ao poder, o que se confirmaria por ser ela quem cuida da casa e dos filhos da "sinhá branca”. Mas “autoridade no estudo doméstico” tem ainda um tom de exagero, ao apresentar a "mulata velha" como uma pretensa "bacharel nas ciências do lar”, já que o doméstico é identificado com o estudo.

A “mãe preta” é escrava, e caracterizada como sendo “mulata velha, séria e bondosa”. E aí já existe uma certa imprecisão: pois ela é, ao mesmo tempo, “preta” e “mulata”. Mas a velhice parece igualar ambas as condições; uma vez que a cor indicaria seu status, e a idade o tipo de função que estaria apta a realizar.

Mas “mãe preta” é um termo, novamente, usado para se referir a um parentesco, cujo outro pólo da relação são os filhos-brancos. Ela “tinha a grave incumbência de criar todos os meninos da 'sinhára' ” branca. Essa criação envolvia, segundo o prólogo, o asseio das crianças (que incluía o banho no colo da “mãe preta”), a narração de histórias em serões e as canções de ninar. Esses cuidados realizados pela “mãe preta” são, como de costume, muito adjetivados. Eram “cuidados especiais”, “carinhosos” e “dedicados”. Há, também, uma ênfase maior na personagem enquanto contadora de histórias, de modo que ela é descrita em ação, e qualificada novamente: suas histórias são “alegres e divertidas”. 
Depois desse prólogo, ao longo do livro, a “mãe preta” aparece como narradora de histórias num serão, contando as proezas dos bichos. E é justamente por ser "conhecedora dos bichos e das coisas da mata” que a contadora é tão valorizada. Todo esse seu saber tradicional fica evidenciado em inúmeras passagens das histórias:

"Só há no mato um pau que ele [o jaboti] não quer que venha sobre suas costas; e por isso, quando pressente alguma trovoada, foge bem longe do tal pau.

- Qual é? Perguntaram os meninos.

- É o taperebazeiro, ou cajazeiro, como denominam em outros estados.

- E por que tem ele medo do taperebazeiro?

- Porque essa árvore é carne de cão.

- Ah! é carne de cão... então não morre...

- Não. Ele cai no chão e torna a grelar por toda a extensão que fica sobre a terra.

Por isso, quando um Jaboti sente um taperebazeiro no seu costado, ele perde a esperança de viver e trata logo de fazer seu testamento e encomendar a alma a Deus.

Vamos ao caso.

(...) mutuca?

Por que razão, perguntou a Mãe Preta, tapuio não mata

- Então tapuio não mata mutuca, perguntou por seu turno e muito admirado, o pequeno Eduardo.

- Não mata, não.

- Ora essa! E quando a mutuca ferra a gente, com aquele ferrão que tanto dói, não deve se matar a mutuca?

- Nunca, e eu lhes digo porquê.

(...)

De sorte que o prudente tapuio, temendo ser azoinado e atormentado por milhões de mutucas, prefere não matar a primeira que lhe vem martelar os ouvidos e sugar-Ihe o sangue.

- E o que faz ele para ver-se livre de tão insuportável inseto?

- Ele só diz-Ihe: vai com quem te mandou! Vai com quem te mandou! - e ela se retira zunindo como um pião."235

A “mãe preta” é apresentada como extremamente versada nessas explicações sobre nossa fauna, flora e os nativos do Brasil. Sabe até mesmo os nomes de variantes regionais da árvore de que o jabuti tem medo, e o modo correto de se lidar com as mutucas. Todos esses saberes tradicionais parecem estar concentrados nela, e alguns deles parecem mesmo ter migrado dos “tapuios” para o conhecimento geral do povo. De certo modo, “tapuio” e "mulata velha” têm certa semelhança no que tange ao fato de serem repositórios de inúmeros conhecimentos sobre as maneiras de se lidar com a natureza brasileira. São justamente essas lições de "ciência popular” da terra, que ela transmite aos meninos, e que o autor põe à disposição de seus leitores. 
No entanto, a personagem construída por Luiz Demétrio Juvenal Tavares não é, somente, uma mera "negra velha contadora de histórias de Trancoso”. Essa “mãe preta” é igualmente versada na literatura escrita, e procura fazer com que sua audiência se exercite na leitura dos livros que ela escolhe como sendo adequados.

“Hoje, - disse a Mãe Preta com tristeza, quando chegou a hora do serão, - vamos ler uns pequenos romances, cujo autor se ocupa em narrar os desastres de alguns desses amigos domésticos, que nos servem em casa, de utilidade e divertimento: são o cão, o gato, o passarinho, o galo, a galinha, etc., etc.

- E os ratos também, disse Anica.

- Nada disso, respondeu Mãe Preta: esse é um companheiro intruso e muito prejudicial.

Em seguida, tirando do bolso um livrinho, abriu-o e o deu a ler ao menino mais velho, que logo começou a leitura, indo ela notando os erros que cometia." ${ }^{236}$

Nesse trecho, percebe-se que a "Mãe Preta" é muito mais do que uma contadora de histórias folclóricas; ela também possui conhecimentos sobre a "literatura infantil publicada”. É iniciada, portanto, na “norma culta”, numa certa “alta cultura”, na parcela alfabetizada da população. Selecionando um livro cujas histórias tivessem proveito para os pequenos, ela incentiva e supervisiona o exercício de leitura da criança mais velha presente no serão. Fica então, atenta aos erros nos quais a criança poderia incorrer para, em seguida, corrigi-los.

A representação em questão se parece, nesse momento, muito mais com a figura de uma “preceptora”, quase uma professora domiciliar, do que com a “ama remanescente da escravidão”, conhecedora de histórias tradicionais, tal como expressa no prólogo.

A “mãe preta” de Luiz Demétrio Juvenal Tavares é, portanto, absolutamente ambígüa. É uma “querida mulata velha”, escrava, ama, que conta histórias de bichos. No entanto, possui também as habilidades de uma “civilizada professora branca”, como escolher leituras, supervisionando e corrigindo erros de leitura. Trata-se, nessa medida, de uma "negra civilizada”, tal qual uma "branca”.

No poema a seguir, o escritor Murillo Araújo ${ }^{237}$ constrói uma espécie de ode à figura da mãe-preta, descrevendo-a e justificando a razão de ser digna dessa homenagem:

\section{“MINHA MÃE PRETA}

Minha mãe-preta já pequena de velhice -

\footnotetext{
${ }^{235}$ Idem. p. 23, 24 e 34.

${ }^{236}$ Idem. p. 34 e 35.

${ }^{237}$ Murillo Araujo. A illuminação da vida. Rio de Janeiro, sem editora, 1927. s/p. (Poemas compostos entre $1922 \mathrm{e}$ 1927.)
} 
é hora do sono: escute a minha cantilena como escutei as suas já

na meninice.

Quando com o vulto negro, com a carapinha alvejada,

você erguia uma luz por sôbre nosso berço

e nossos olhos riam para vê-la -

parecia - Mãe-Preta - a noite enluarada

que nos trouxe a graça de uma estrêla!

Quando nos carregava nos seus ombros...

ou nos furtava os doces em segrêdo...

ou nos acalentava nos assombros do nosso mêdo -

oh Mãe-Preta, oh luz mansa

era o seu coração nosso melhor brinquedo,

o ingênuo coração que vivia e morria

com inocência de criança.

Quando a Noite na sua meia-língua

engrolava as histórias

com aquela voz cansada como o sono...

você - mísera enfêrma das senzalas -

você - dor e abandono -

tinha a ilusão e a fôrça de falar-nos só das glórias,

dos palácios de luz, dos príncipes de galas

e das princesas de vestido côr do dia...

você mesma era como a moura encantada,

uma figura de seus contos animada

que viesse e nos levasse aos reinos da Harmonia.

Oh Mãe-Preta, Mãe-Preta -

Deus quis dar-Ihe essa côr entenebrada

para esconder a sua dor calada

sem nos fazer chorar pela sua ânsia!

Deus quis dar-Ihe essa côr de silhueta

Para torná-la mais indefinida

Mais irreal de sonho, mais perdida

Nos longes da memória e da distância...

Deus quis você bem símplice - Mãe-Preta

Deus quis você bem docemente sombra

Para que fôsse a sombra azul da Infância!"

A “Mãe Preta” é descrita como sendo "negra”, “escrava”, “africana”, “pequena de velhice” e com “a carapinha alvejada”. A ama era, portanto, uma metáfora da noite enluarada: era negra como a noite e seus cabelos brancos como a lua. As crianças, entre elas o poeta, gostavam muito de sua “Mãe Preta”, sorriam apenas ao vê-la. Mas ela era digna de tanto afeto justamente porque tratava as crianças com muito carinho: carregava-as ao ombro; era cúmplice no roubo de 
doces; cantava para que dormissem e acalentava-lhes nos momentos de medo provocados pelas histórias que ela própria contava. Aliás, seu desempenho como contadora de histórias merece descrições bastante detalhadas: narrava seus racontos à noite, com uma língua engrolada (meia portuguesa, meia africana); falando sobre príncipes, glórias, harmonia e a moura encantada...

Mas a "Mãe Preta” surge no poema novamente como um ser extremamente abnegado. Escrava “mísera enferma das senzalas” e sinônimo de “dor e abandono” ela só falava de coisas boas, harmoniosas e encantadas. Essa “mãe afetiva” é, portanto, também interpretada como uma “forte”; em função do exemplo de superação que fornece. Ao agir desse modo, "Mãe Preta” era reconhecida como a moura encantada de suas histórias, porque só encantamento permitiria essa transformação de sofrimento em amor.

Esse sofrimento, segundo o poema, fora Deus que promovera: Deus escolhera enviar a negra (logo, escrava), de modo que a sua dor fosse escondida/camuflada ou mesmo justificável. Ele a enviara em sacrifício, para que as crianças não sofressem com sua ausência.

Fora Deus também que determinara que a negra fosse sombra; ou seja, companhia inseparável e zelosa dessa infância, tornando-a, desse modo, ainda mais indefinida na memória afetiva e infantil: cada vez mais próxima do sobrenatural e do sonho.

A poesia revela, por fim, a gratidão à "Mãe Preta”, por parte daqueles que foram criados por ela. O autor tece elogios à "santidade” e "benignidade” da figura, sacrificada por Deus para não fazer os brancos - e também ao próprio poeta - sofrerem. Nessa medida, não são escamoteados o peso da escravidão e o estatuto de cativa da “Mãe Preta”. Mas seus filhos brancos conseguem se eximir dessa culpa, uma vez que essa insuspeita mãe afetiva cumpria os desígnios de Deus, ainda que estivessem cientes de que ela era sacrificada por eles. A “Mãe Preta” é amor “simples” e é “sombra”. Também a escravidão é sombra; é iluminada nos outros, mas apagada na experiência da escravidão doméstica, onde esse personagem é símbolo dileto.

Mais uma “mamãe-preta” que - de modo semelhante - se sacrifica, "matando-se de trabalhar”, mas sempre carinhosa com seu filho branco, está expressa no poema de Antonieta Borges Alves ${ }^{238}$ :

\section{“MAMÃE PRETA}

Dorme, nenê,

Dorme, nenê, que o bicho vem pegá... dorme nenê...

... E o nenê da sinhá

\footnotetext{
${ }^{238}$ Antonieta Borges Alves. Brasil - Canção. São Paulo, Escolas Profissionais Salesianas, 1954. p.46.
} 
dormiu no colo da negra velha.

Agora a mamãe-preta vai dormir?...

- Que! não vai não!

Mãe-preta vai engomar,

vai torrar café,

vai fritar torresmo,

vai fazer sabão...

Mãe-preta não dorme, não!

De repente sinhozinho

faz berreiro lá no quarto:

Ela pega sinhozinho,

põe-se a cantar outra vez...

- Que é isso Mamãe-preta? Você não descansa?

Você vai trabalhar com...

com êsse chorão nos braços?...

- Quá o que! a lã não pesa pro carneiro...

- Verdade! A lã não pesa para o carneiro!...

E mamãe-preta, de tão boa e mansa,

é realmente uma ovelhinha branca,

que afagou o sinhozinho,

que embalou o Brasil!"

A “mamãe preta” desse poema também é descrita como extremamente abnegada. Trabalha muito nas mais diversas funções: “engoma”, “torra café”, “frita torresmo”, "faz sabão” e ainda cuida do "sinhozinho" com o maior carinho. Talvez por essa razão seja chamada "mamãe preta” do "sinhozinho” branco. A “negra velha” nina a criança de sua sinhá - cantando para ela que, entregue, dorme em seu colo. Mas, para fazer tudo isso, “mamãe preta” não dorme. Tudo indica tratar-se de uma escrava, ainda que esta informação não esteja expressa no poema. Inclusive os “pronomes de tratamento” - “mamãe preta”, “sinhá” e “sinhozinho” - parecem fundamentar a hipótese.

A narradora do poema “denuncia” a excessiva exploração do trabalho da personagem. Não obstante, a própria “mamãe-preta”, solicitamente, diz não se importar, estaria "acostumada” a realizar várias tarefas simultâneas, dentre as quais incluía carregar o bebê, de modo que “a lã não pesa para o carneiro”. Assim, por sua prontidão, conformidade e disponibilidade para o 
batente; a "mamãe preta” do poema é tida como "boa” e "mansa” assim como uma ovelhinha branca.

Essa negra resignada à sua condição de escrava é tão “boa”, “meiga” e “cordata” que chega até a ser comparada aos brancos; ainda que no caso, os "brancos” sejam animais. Mas a “mamãe preta” ao “afagar” o sinhozinho estava, em verdade, “embalando o Brasil”. Dessa maneira, ela estaria se sacrificando pela pátria, em sua lida desgastante. E nessa metáfora, em que a personagem “cria”, “embala” e “nina” o Brasil - corporificado numa criança branca - há uma leve alusão à mestiçagem. O menino branco-Brasil, em sua socialização, entrara em contato íntimo com a bondade e cultura africanas surgindo, então, um Brasil-adulto mestiço.

A relação tecida por essas mães-pretas com seus filhos brancos aparece, de ordinário, como bela e afetivamente construída por meio de incontáveis cuidados, entre eles: aleitamento, alimentação, banho, vestuário, canções de ninar, sono velado, rezas, além da reincidente narração de histórias. Trata-se, portanto, de um parentesco "social” e "generoso", construído sob o hierárquico regime escravocrata. Mas esse parentesco meramente "social”, em algumas das fontes analisadas, era reforçado por um elemento de "natureza": o leite. A maternidade da mãepreta, nessa medida, parece se definir de forma híbrida, mesclando o "natural aleitamento” com os “sociais cuidados". 239

Os “atos de amor” relatados nas histórias são, por um lado, realizados pelos “filhos de leite”, quando salvam suas mães de criação. Por outro, pelas próprias negras, que repetidamente se sacrificam por seus "filhos": protegendo-os das duras leis de seus pais naturais; dando-lhes amor, quando o que possuíam era apenas o "trabalho esgotador" e a "infelicidade das senzalas". Por conseguinte, tanto mãe-preta quanto filhos brancos e suas famílias aparecem como sendo bondosos, capazes de atos de desprendimento para contentar seus entes mais queridos. São todos, portanto, dignos e civilizados. Nesse sentido, no quesito moral, a mãe-preta é muito próxima (e quiçá, mais “bondosa”) de seus senhores brancos.

Essa relação de proximidade afetiva para com a família senhorial também revela os trâmites próprios da rede de negociação existente numa escravidão paternalista, onde a liberdade é o maior "prêmio", mas pelo qual a escrava deve ser "grata”, tornando-se agregada da família. E, aqui, o agregar-se é sinônimo de um processo de embranquecimento promovido pelo afeto. Isso porque é o afeto que leva à liberdade: um status semelhante ao do branco. Mas, como venho

\footnotetext{
${ }^{239}$ Utilizo, aqui, o conceito de "híbrido" tal como definido por Bruno Latour, em: Bruno Latour. Jamais Fomos Modernos. São Paulo, Editora 34, 1994.
} 
insistindo, essa semelhança não é integralmente efetivada: a assimilação do escravo da casa (ou do agregado) é sempre de "segunda ordem”, quando se traz à tona, também, sua diferença.

A arbitrária instituição não deixa, assim, de se fazer presente, sendo tratada nas fontes com uma complacência culpada dos sinhozinhos (então adultos); ou tomada como o grande sacrifício a que as negras se submetiam, ora por amor, ora pela pátria. Ela, ainda, aparece parcialmente redimida pela escravidão doméstica; é como se a “intimidade” amenizasse a violência.

Nesses momentos, mãe-preta surge sob a insígnia da “quase santidade”, dando amor quando o que recebia era arbítrio. Essa santidade das negras velhas é, por sinal, outra característica reincidente na descrição da personagem; por vezes bordeando o "civilizado" catolicismo, por vezes se aproximando da "liminar” magia.

\section{Mãe-preta e as nuances da escravidão}

No segmento anterior, eu havia pontuado certas características sobre a maneira com que a escravidão aparecia nas fontes, que também traziam representações da mãe-preta. Raramente ausente, a instituição, no entanto, surgia sempre "nuançada”. Detenho-me, agora, justamente sobre essa questão, ao analisar as obras. Alguns dos textos que serão trabalhados já foram apresentados ao leitor, outros são inéditos.

Em Luiz Delfino dos Santos ${ }^{240}$, a escravidão é vista como um tempo feliz e memorável, inclusive para a ex-escrava:

\section{A PRETA DA CABANA}

Esta preta que vês junto à cabana, Velha, gasta, pedindo-te uma esmola, Teve na terra benfazeja a escola Do trabalho, do amor, da luta humana.

Deixou a pátria tórrida africana

Pelo Brasil, onde é soberba a flora;

$E$, no país em que ela é livre agora,

Viveu escrava e a um tempo soberana.

Misturou o seu sangue ao nosso sangue, O seu suor, no campo, ao suor da aurora, Deu força e alento ao nosso corpo langue.

Helena, inda hoje embala-nos nas sestas,

\footnotetext{
${ }^{240}$ Luiz Delfino dos Santos. Poesia Completa. Florianópolis, Academia Catarinense de Letras, 2001. Tomo I, p. 466. (Poema escrito entre 1844 e 1910)
} 
Como ria no lar conosco outrora

E eram suas também as nossas festas...

É possível, após a leitura da poesia, supor uma datação posterior à Abolição, isso porque o narrador/autor - abolicionista - fala sobre o passado da, então, liberta Helena, lembrando-se dela como cativa.

A escravidão evoca lembranças de um tempo mais agradável e saudoso para o narrador; e de melhores condições de vida para a preta; agora livre, "a um tempo soberana" e "junto à cabana”, encontra-se "velha, gasta, pedindo uma esmola". Mas, a negra "na terra benfazeja” de seu senhor aprendeu as lições "do trabalho, do amor e da luta humana”. Helena, tal como toda a massa de escravos, é lembrada como vinda da África, a qual é representada de maneira negativa é “pátria tórrida” - em relação ao Brasil, “onde é soberba a flora”. O Brasil, como é comum, sempre adjetivado positivamente por suas qualidades e riquezas naturais.

Mas agora (no momento da escritura da poesia), quando a preta é livre, está "velha, gasta e pedindo esmola”. Este é um quadro muito diverso de quando a personagem "viveu escrava", “rindo”, junto do narrador, na casa dele, onde as festas eram também suas.

Desse modo, é cabível dizer que o narrador da poesia descreve a escravidão numa versão "levemente saudosista", ainda que enfatize os resultados da exploração no corpo da ex-escrava. Quando a instituição foi abolida, teria deixado a ex-escrava Helena na miséria, numa situação pior do que a do anterior cativeiro. A saudade proporciona uma certa atmosfera de "carinho" - o poeta ainda se vê embalado pela lembrança de Helena como a conheceu, não como hoje ela se apresenta.

Uma certa mestiçagem aparece no texto, numa mistura de sangues: "misturou o seu sangue ao nosso sangue”; e também nessa mistura e convivência íntima "deu força e alento" ao "nosso corpo" que era "langue”. Helena mestiçou, ainda, nossa paisagem por meio de seu suor, misturou "o seu suor, no campo, ao suor da aurora”. É notável na poesia essa ênfase na mistura dos fluídos corporais, que configuram contribuições positivas da ex-escrava para o Brasil, dando-lhe a "força” expressa no "suor de seu trabalho", que começava cedo, pela aurora. O autor reconhece, portanto, o sacrifício da escrava africana - mediante um trabalho que a esgota - para a edificação de uma "nação brasileira", presente nas metáforas de "nosso sangue", "aurora" e "nosso corpo". 
Uma escravidão mais “positivada”, ou ao menos com nuances, está presente no já mencionado prólogo, do livro infantil Serões da Mãe Preta ${ }^{241}$ :

“No Pará e Amazonas, a 'mãe preta' é um tipo legendário criado pela escravatura. Não sei se no Sul apareceu igual personagem: o que sei, o que todos sabem, pelos tristes fatos da escravatura no Brasil, é que o escravo do Pará e Amazonas em nada era comparável com o do Sul.

Ali o negro era considerado, não como um homem, mas como uma besta de carga, uma simples máquina feita para o trabalho material e meio de enriquecer o branco.

Para ele havia a senzala, coisa desconhecida entre nós; o 'bacalháo' e outros suplícios infamantes, instrumentos cruéis com que o seviciavam e o levavam à mesma estiva com os animais irracionais.

Aqui, não. O escravo era tratado como um membro da família, guardando-se apenas a distinção que naturalmente existe entre o criado e o patrão.

As mulatinhas eram criadas com as meninas, com quem iam à missa e aos passeios, com suas chinelinhas de polimento e tacão alto, com rosários de ouro, etc.

Eram tratadas com recato e dormiam no mesmo quarto em que dormia a família."

Aqui a própria representação da “mãe preta” surge colada à escravidão - "é um tipo legendário criado pela escravatura”. Mas não a qualquer escravidão, a uma específica, recorrente no norte do país, sobretudo no Pará e no Amazonas. Nesses estados, “o escravo era tratado como um membro da família, guardando-se apenas a distinção que naturalmente existe entre o criado e o patrão.” E a essa instituição peculiar nortista contrapunha-se à do Sul: onde o negro não era tratado de modo "humano", parecendo "uma besta de carga”, ou "uma simples máquina”, que enriquecia os brancos. Os castigos a que eram submetidos aí, também lhes "corrompiam a humanidade”, igualando-os aos animais.

Nesse contexto de tanta violência, "humilhações” e "ultrajes”, o autor suspeita que não tenha surgido uma personagem como a “mãe preta”. Sua representação é, assim, aliada e vista como fruto daquela "boa escravidão do Norte”. No entanto, mesmo lá onde a escravidão é “mais suave” e os escravos são tratados “como se fossem da família”, a estrutura hierárquica aparece como limite para incorporação dessa "afim afetiva”, ela é “como se fosse”, mas não "é” da própria família. A assimilação junto à família patriarcal é sempre de segunda ordem, uma assimilação promovida pelo trabalho naturalizado, que levou a uma íntima convivência cotidiana. Nessa medida, a "mãe preta” - escrava - era tratada como um membro da família, "guardando-se apenas a distinção que naturalmente existe entre o criado e o patrão”.

\footnotetext{
${ }^{241}$ Luiz Demétrio Juvenal Tavares. Op. cit. p. 20 e 21.
} 
Mas também, segundo Tavares, é devido a essa convivência próxima que os escravos têm acesso a certas benesses. As “mulatinhas” constituem esse exemplo, ao serem criadas junto com as meninas brancas da família, dormem em seus quartos, e as acompanham em passeios e missas, com “direito” a "rosários de ouro" e "chinelinhas de salto".

A “mãe preta” também ocupa esse lugar social contraditório, o da semi-assimilação à família patriarcal: devido à convivência muito próxima ao realizar seu trabalho, acaba por dividir com a "mãe branca”, a autoridade que rege a casa-grande. Mas ainda sim, a “mulata velha” é “escrava”, empregada na casa de seus patrões, reafirmando que mesmo a "escravidão mais benevolente” é limitativa dessa incorporação que nunca ultrapassa a iminência de ser da família, o tal "como se fosse"...

A expressão “é um tipo legendário criado pela escravatura” é, igualmente reveladora. O termo “legendário" remete tanto a uma valoração positiva (já evidenciada), como a um passado remoto. A escravidão é, desse modo, apresentada como localizada nos tempos quase "imemoriais do antigamente”, tempos de legendas e lendas. Mas o livro fora escrito em 1890, ou seja, um ano após a abolição da escravatura. Há, nesse sentido, possivelmente, uma tentativa de se forjar um afastamento temporal fictício em relação a esse (então) fato recente e "vergonhoso" da história do Brasil: a escravidão, ainda que ela fosse mais “amena” para a "mãe preta”, na terra do autor.

A representação da escravidão, relacionada à figura da mãe-preta, ainda possui outra singularidade: trata-se de ponderações sobre a diferença entre o cativeiro no “eito” e na cidade. Tal comparação fica evidente no conto “Mãe Maria”, de autoria de Olavo Bilac ${ }^{242}$ :

“(...) Comprar e vender escravo era, naquelle tempo, uma cousa natural. Ninguem perguntava a um negro comprado o seu passado, como ninguem procurava saber de onde vinha a carne com que se alimentava ou a fazenda com que se vestia. De onde vinha a velha Maria, quando, logo depois de meu nascimento, meu pae a comprou? Sei apenas que era africana; e tinha talvez um passado terrivel: porque, quando a interrogavam a esse respeito, um grande terror lhe dilatava os olhos, e as suas negras mãos reluzentes e callejadas eram sacudidas de um tremor compulsivo.

Comnosco, a sua vida foi quasi feliz. Na cidade, o captveiro era infinitamente mais brando do que na roça. Aqui, se havia o trabalho sem tréguas, não havia, ao menos, o chicote do feitor. Lá fóra, sim! lá fóra, era a labuta esfalfante do café, os dias terriveis sob o sol implacável, a comida pouco e o castigo muito. Maria, quando eu às vezes lhe perguntava o que era a roça, ficava calada, olhando o chão, como se estivesse revendo com horror o tormento d'essa vida antiga. Um dia despio a meio a camisa de algodão grosso, e mostrou-me as costas e o peito. A pelle preta estava de espaço a espaço cortada de largos vergões, cicatrizes, signaes de queimaduras. Eu, com os meus innocentes olhos de seis annos, olhava

${ }^{242}$ Olavo Bilac e Coelho Netto. Op. cit. p. 15-30. 
aquillo sem compreender. «Como foi isso, mãe Maria?». «Maldades dos homens, Sinhôsinho, maldades dos homens...». (...)"

Nesse trecho, a escravidão na "roça” é contraposta à da “cidade”, considerada mais "branda”, por meio da qual "mãe Maria” teve uma vida "quase feliz”. O eito é caracterizado como o lugar da "esfalfante labuta do café”, "sob o sol implacável”, tal como “o chicote do feitor”, e com “pouca comida”. Na cidade o trabalho ainda é duro, "sem tréguas”, mas também sem o "temido" chicote do feitor, que tanto horrorizava “mãe Maria”.

Fora vítima de incontáveis castigos, que lhe deixaram marcas por todo o corpo, mas principalmente na memória. Aliás, o corpo é o lugar da memória dos escravos, já que não lhes era permitido levar consigo muitos bens nos trânsitos forçados da África para o Brasil, ou entre seus senhores. Como alertara Mauss, falando sobre o estatuto do escravo no direito romano: “servus non habet personam. Ele não tem personalidade, não possui seu corpo, não tem antepassados, nome, cognomen, bens próprios."243 Assim, esse corpo que não pertencia a "mãe Maria”, era marcado pela violência de seu senhor no eito. E a memória inscrita nesse “suporte” é terrificante. Evoca na escrava da narrativa, as mesmas reações de medo dos tempos idos: “olhos dilatados”, “mãos sacudidas por um tremor compulsivo”. E lembrar era um ato tão poderoso, sobretudo para os escravos (que só têm a memória como repositório do passado) que “Maria”, quando instada a relembrar, revivia aquele mesmo passado e, calada, ficava olhando para o chão...

Junto da família de seu "sinhôsinho", “mãe Maria” não estava mais submetida às “maldades dos homens”, mas ainda assim era escrava. E essa marca da escravidão aparece, sobretudo, na constatação da ausência de raízes do escravo: “comprar e vender escravo era, naquelle tempo, uma cousa natural. Ninguem perguntava a um negro comprado o seu passado, como ninguem procurava saber de onde vinha a carne com que se alimentava ou a fazenda com que se vestia. De onde vinha a velha Maria, quando, logo depois de meu nascimento, meu pae a comprou?” Segundo Manuela Carneiro da Cunha: “um traço que é comum às escravidões, [é] que o escravo é sempre, por definição, um ser sem raízes. Só através de um corte radical com todas as lealdades que fazem de um homem um membro da sociedade é que se pode torná-lo um ser completamente apropriável por outrem, outra família, outra sociedade. O escravo é assim, por excelência, um estrangeiro, não enquanto membro de uma outra sociedade da qual proveio, mas enquanto permanentemente alheio à comunidade que o escravizou. É alguém que deve ser

\footnotetext{
${ }^{243}$ Marcel Mauss. “Uma categoria do espírito humano: a noção de pessoa, a de ‘eu' ”. in: Marcel Mauss. Sociologia e Antropologia. São Paulo, Cosac \& Naify, 2003. p. 389.
} 
mantido na sua condição de estranheza. É um outro. E é um outro que não pode ter lealdades próprias, mas apenas lealdades mediadas pelo seu senhor.”244

Assim é “mãe Maria”, sem origem ou passado, de modo que quando adentra a casa senhorial, começa ali a tecer novos laços afetivos e sociais, todos mediados por sua situação de escrava, ainda que escrava doméstica. A escravidão revela-se na medida em que até mesmo as relações afetivas tecidas por “mãe Maria” só existem por determinação de seu status como escrava, e não por auto-determinação e escolha próprias.

No poema “Dança em volta do fogo”, de Cassiano Ricardo”245, a figura da ama-de-leite aparece intimamente conectada com uma imagem de animalização, promovida pela escravidão.

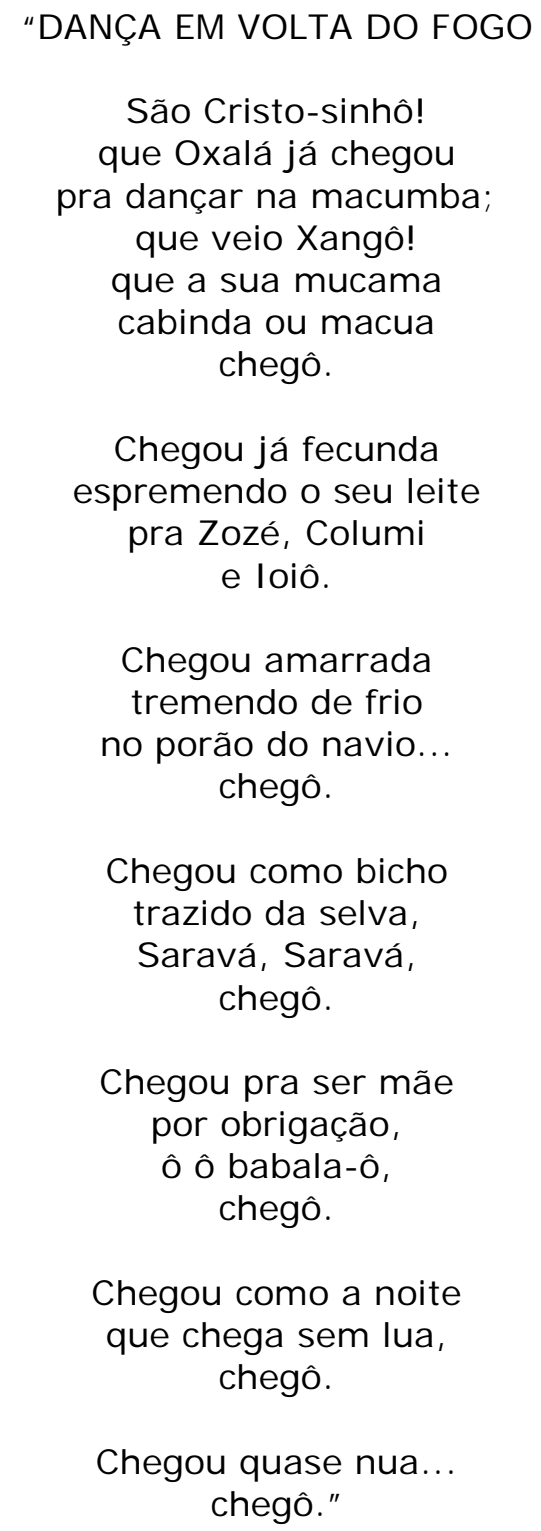

\footnotetext{
${ }^{244}$ Manuela Carneiro da Cunha. Negros Estrangeiros. São Paulo, Brasiliense, 1985. p.11 e 12.

${ }^{245}$ Cassiano Ricardo. Martim Cererê: O Brasil dos meninos, dos poetas e dos heróis. São Paulo, Edição Saraiva, 1928/1962. p. 71 e 72.
} 
O poema descreve justamente a escravização daquela que será ama-de-leite e "mãe por obrigação”. "Mucama cabinda” ou “macua”, sua origem e seu passado pouco importam depois que se tornara escrava numa travessia marcada pela "animalização”: "no porão do navio”, "tremendo de frio”, “nua”, como "bicho trazido da selva”. E até as palavras usadas para sua caracterização têm um tom animalesco: chega “fecunda”, “espremendo seu leite” tal como uma fêmea leiteira, para cumprir sua maternidade obrigatória - amamentar Zozé, Columi e Ioiô.

Ao contar a trajetória da ama, o poema destaca a viagem no navio negreiro como um ponto de inflexão cruel na vida desses negros, que chegavam ao Brasil parecendo animais, com seus laços prévios abortados, e valorizados apenas pelos atributos físicos que lhes qualificariam para serviços na comunidade que os escravizou. Essa chegada via porão do navio é metaforizada - na poesia - com a chegada da noite sem lua, e a própria escrava nua é mimetizada com a noite escura.

Quando Raul Bopp ${ }^{246}$ evoca a figura da “mãe-preta” (título do poema), revela o momento anterior à travessia da Calunga, o instante da escravização na África:

“MÃE-PRETA

- Mãe-preta conte uma história

- Então feche os olhos filhinho:

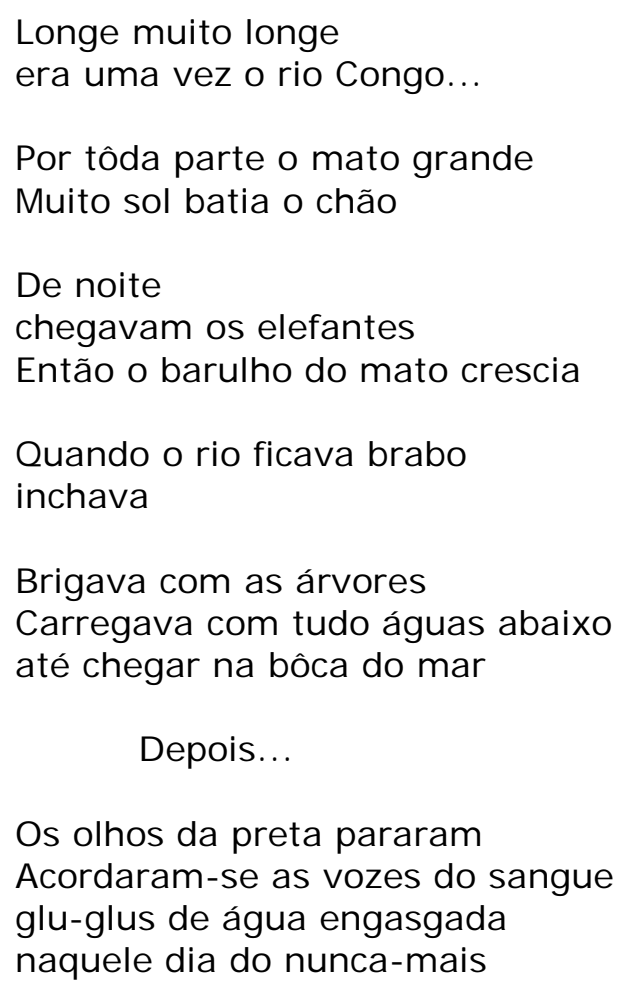

${ }^{246}$ Raul Bopp. “Urucungo” Poesia Completa de RaulBopp. Rio de Janeiro/São Paulo, José Olympio Editora/Edusp, 1932/1998. p. 95 e 96. 


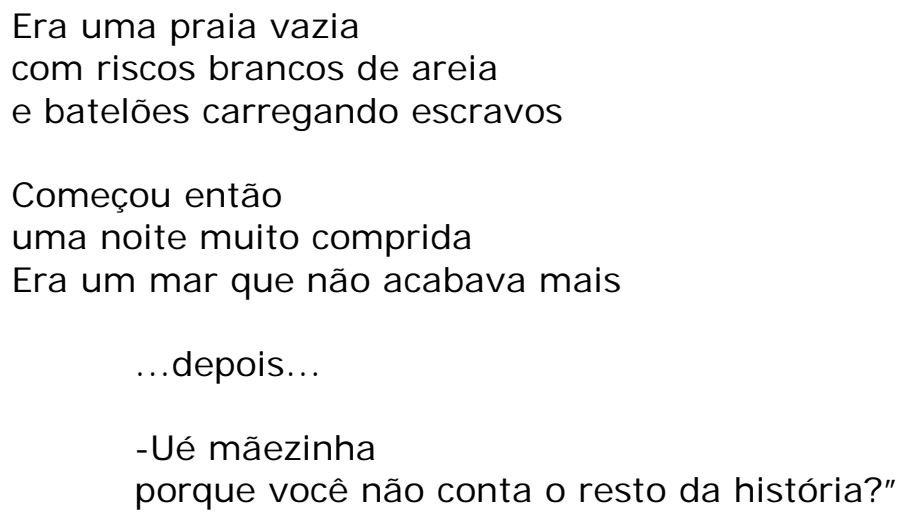

A “mãe-preta”, a contar histórias para seu "filhinho branco e de criação", relembra de sua própria história. Evoca a África, como sendo um lugar mágico onde a natureza é personificada: “o rio fica brabo”, “briga com as árvores” e as leva, contra a vontade, para a "boca do mar”. E, ao falar do mar, “mãe-preta” relembra, com melancolia, o dia em que fora escravizada; numa atitude semelhante àquela de “mãe Maria”, as lembranças são revividas corporalmente, com “olhos parados”, “vozes de sangue acordadas”, e "glus-glus de água ainda a engasgar” a negra, no presente da narrativa. Nesse dia que selara seu destino - o “dia do nunca-mais” ao rio Congo e à África - ela, junto de batalhões de escravos, é enviada ao Brasil no porão dos navios tumbeiros, e a viagem é novamente descrita como uma “noite muito comprida”, num mar que não tinha fim...

Ainda comovida, a "mãe-preta” não consegue continuar a história que contaria sua jornada como escrava até se encontrar ali, como “mãe de criação na casa senhorial”, "mãe-preta de filho branco". Como alertaram Mauss e Manuela Carneiro da Cunha, o escravo não tem raiz, não tem história, não tem passado, a não ser o presente das relações mediatizadas pela escravidão, pela casa senhorial.

As diferentes representações da escravidão, sobretudo evocadas pela figura da mãe-preta e das negras velhas, revelam uma caracterização mais nuançada, ou, ao menos, mais pessoalizada. Nessa medida, mãe-preta, ainda que escrava, é sempre escrava de um quilate “peculiar”.

Nos textos, o afeto de que é promotora, e também objeto, acaba por ser um impeditivo para descrições chapadas e categorias acaçapantes. A mãe-preta é, dessa maneira, porta de entrada para um universo de categorias sociais tensas e contraditórias. Os narradores, em geral, têm um carinho especial pela mãe-preta, descrevem-na enquanto escrava; mas a escravidão junto 
deles é sempre “mais amena” - mais detalhada nas afeições - se comparada a outras; seja no eito, seja no sul do país, ou mesmo com outros senhores tidos como mais cruéis.

Mesmo assim, a escravidão é traço indelével, que se revela dentro destas famílias patriarcais permissivas: faz-se presente na inexistência de um passado no escravo, cujos laços sociais próprios foram esgarçados na forçada travessia do Atlântico. E o que lhes restou foi tecer novos vínculos agora mediados pela casa senhorial. Ou seja, nas fontes, a escravidão é sempre limitativa de laços sociais próprios.

Mas em outras passagens do material selecionado para análise, aparecem pistas sobre a existência de relações sociais próprias à escrava. Trata-se do vínculo da mãe-preta com seu filhopreto. São as representações sobre tal rebento natural da personagem que passo a analisar.

\section{Mãe-preta de filho preto}

Ser mãe-preta significava, nos textos literários aqui explorados, ser mãe de um quilate diferente - “mãe afetiva”, “mãe de criação”, “mãe de leite” - mas nunca “mãe natural”. Isso porque mãe-preta é um termo que tem contrapartida no filho branco, que pela descontinuidade de cores no fenótipo, não era filho de seu próprio ventre. Desse modo, o termo mãe-preta não teria sentido se fosse aplicado para sua cria natural, o filho preto. Mas eles, filhos pretos, também estão presentes nas fontes. Para ter condições de aleitar um filho branco, mãe-preta muitas vezes estivera grávida de um filho preto, que é descrito de diferentes modos.

“Tia Jacinta”, personagem do conto de Cornélio Pires, tinha um “fio” além de seu "fio de leite”. E quando ela foi vendida para ser ama-de-leite, seu filho natural também foi comprado pelo pai de Nho Dô. Ele tinha por volta de um mês: a mesma idade do leite da escrava:

“Seu avô tava percizando de ua maman p'ra seu tio Nho Dô, que tinha nascido; eu tava cum leite de meis... meu marido tinha sido vendido p'runs home da província de Mina... (...) Quim. (...)

- Óia, negra... póde pegá seu fio... Vendí ocê c'o criolinho p’ra nhô

Fiquei durmindo em casa e o meu fio durmia na merma cama, ua cama maciu, limpa, c'o meu fio de leite, seu tiu. (...). E Nhô Dô ia cresceno c'o meu fio... Era ua buniteza. Criei os dois (...)" 247

Na história, o filho preto de Tia Jacinta tinha um tratamento muito parecido com o de seu "fio" branco. Dormiam na mesma cama e eram criados com eqüidade pela ama, que se orgulhava do crescimento de ambos. Os meninos desenvolveram amizade entre si, e viviam brincando entre os filhos dos demais escravos da propriedade: 
"As criança crescia. No sítio era ua buniteza! Nhô Dô no meio dos criolinho já aprendia brincá! E-vê que tô veno tudo:

- Tempo será!

- Se pudé me pegá!

- Galinha gorda!

- Fejão sem dá!

Despois:

- Meu cumpadre! Quantos pauzinho tem no céu?

- Vinte e um queimado!

- Quem queimô?

- Ladrão dos porco!

- Vá que se prenda?

- Bem dito, vá...

E zele tudo pegano p'ra mão ia passano imbaxo do braço do outro inté fazê ua corrente sempre cantano:

- Galin-fon-fon! Da cor do limão! De Nossa Sinhora! Da conceição...

- Meu cumpadre!

- Sinhô!

- Tem ua corda p'ra me imprestá?

- Tenho, mais ta cheia de chichica de galinha.

- Serve ansim mermo!

E tia Jacinta ria a bom de rir, batendo as mãos, num enlevo.

- Esticavam os bracinho e caium tudo no chão... O maió abria a mão inriba... os tarzinho tavum tudo de cócre...

- Quem vai p'ro céu?

Eles davum um pulo: bateu c'a cabeça na mão, ia p'ro céu, num bateu, ia $p^{\prime}$ ro inferno... Tudo quiria i no céu... P' ra Nhô Dô zele baxava bem a mão... De repente um não ascançava... E tudo in roda daquele garrava gritá dexano desinxavido e quereno chorá: vintém!"248

- Cuiza-ruim tem-tem! Cuiza-ruim tem-tem! Da cor de um

As crianças, ao conviverem cotidianamente por meio das brincadeiras, e dividindo a mesma “mãe de leite”, acabam por também tecer entre si um laço de parentesco afetivo: o filho branco de Tia Jacinta trata seu filho natural por “cumpadre”. Nessa relação de compadrio, o “filho de leite” - parte de família branca e senhorial - trata o filho de sua escrava por um termo (“cumpadre”) que implica numa reciprocidade, no limite "lacto-sentimental”, que nubla a diferença hierárquica existente entre eles.

O filho natural de Tia Jacinta, no entanto, não usa o mesmo termo de tratamento, chamando seu "irmão de leite" - também filho de seu senhor - por "sinhô". O nominativo utilizado é mais respeitoso, e evidencia a diferença de status entre ambos: seu “irmão de leite” é também seu senhor.

\footnotetext{
${ }^{247}$ Cornélio Pires. Op. cit. p. 158-165

${ }^{248}$ Idem.Grifos meus.
} 
Durante os jogos infantis, o filho preto de Tia Jacinta retribui essa generosidade afetiva (ser tratado como cumpadre) de seu irmão de leite protegendo-o em meio aos outros “criolinhos”, tratando-o como “café com leite”: “p’ra Nhô Dô zele baxava bem a mão...”.

No entanto, no fim desse mesmo conto, o filho natural de Tia Jacinta é retirado da história. Quando ela é vendida para o Capitão Fidele, ele permanece junto aos seus antigos senhores, e não volta a ser mencionado. Deste modo, o único laço social próprio da escrava desaparece; revela-se como o foco do autor era a relação entre a mãe-preta e seu filho branco, que heroicamente termina por salvá-la.

Mas nem sempre essa relação entre filhos brancos e pretos, da mãe-preta, surge de modo positivo. No livro infantil, Pai João Menino ${ }^{249}$, que conta a história da infância de Pai João filho natural de uma ama-de-leite -, o compartilhamento do leite “materno” não criou nenhuma espécie de parentesco.

\section{“O MENINO MAGRO}

Com o menino no regaço, a escrava dizia:

- Mama, meu filho, mama. Eu escondi leite para te dar. Ioiôzinho branco quer tudo para êle, mas êsse leite que guardo no meu peito foi Nosso Senhor quem me deu para te dar. Mama, meu filho, mama...

Nesse momento, veio correndo o mulato Pemba, e avisou a escrava:

fome.

Dona Sinhá mandou dizer que menino branco está com

- Mama, meu filho.

- Anda, desavergonhada. Olha que eu vou dizer.

- Vá logo, marvado.

E a escrava, medrosa, ajeitando o filho entre os panos da catre de couro, saiu correndo para a Casa Grande. O Pemba olhou o menino, e como não sabia ter piedade de ninguém, disse indiferente:

- $\quad \mathrm{I}$ ! ! Até se vê os ossos.

Nesse tempo de Pai João menino, êle era magro, magrinho, bem magrinho. A pele parecia uma túnica pegada aos ossos.

\section{A CATAPORA}

- Você merecia apanhar mais, negra atrevida, falou D. Sinhá com as mãos nas cadeiras. Para outra vez, não sou eu quem Ihe dá, não; eu mando o Damião lhe meter o relho. Então, você se atreve a não querer dar de mamar ao seu patrão, ama maldita?

- É que ioiôzinho está com catapora, e o meu filho... está bom.

- Que bom, nada. Quem pegou catapora no menino foram vocês. Foi você quem trouxe a mazela da senzala.

I oiôzinho no berço choramingava, e D. Sinhá segurando-o nos braços roliços, levou-o ao regaço da negra.

- Anda, atrevida, dá de mamar ao menino.

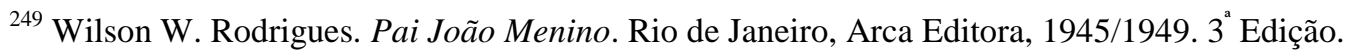


- Mama, ioiô.

E num tom mais baixo:

- Como seu rosto até parece moita de catapora.

PRESENTE

Quando a escrava entrou na senzala, o negrinho chorava:

- $\quad$ Está com fome

Colocou-o no regaço, repuxou o seio, deu de mamar.

- Meu filho, hoje não te dou apenas leite. Dou mais. Muito mais. Dou também uma moléstia. ${ }^{250}$

Como o foco narrativo encontra-se no menino negro, pela primeira vez suas necessidades e, neste caso, sua carência, surgem com premência. "Pai João” é descrito como “fraco”, pois é privado do alimento natural de sua mãe, que saciava a contragosto a fome do filho da "Dona Sinhá”. Na passagem não há tampouco nenhuma demonstração de afeto da ama pelo filho de sua senhora; ao contrário, estar com ele e amamentá-lo é sempre uma obrigação realizada sob ameaças de castigo físico.

Como conseqüência disso, é notável a diferença de termos de tratamento usada pela ama: “filho” refere-se unicamente ao seu "filho preto”, "Pai João Menino”; e “ioiô”, diminutivo de "sinhozinho", para o "filho da sinhá branca”. Nesta história as crianças, ao compartilharem os “peitos” e o "leite”, não se vinculam em "parentesco" ou numa relação afetiva: elas compartilham, tão somente, doenças. Doenças que Dona Sinhá alega terem sido originárias da senzala.

Augusto dos Anjos, quando escreve um poema sobre uma ama que tivera na juventude, também reflete diante de seu privilégio sobre um leite que não era de sua mãe natural:

“RICORDANZA DELLA MIA GIOVENTU

A minha ama-de-leite Guilhermina

Furtava as moedas que o Doutor me dava.

Sinhá-Mocinha, minha Mãe, ralhava...

Via naquilo a minha própria ruína!

Minha ama, então, hipócrita, afetava

Susceptibilidades de menina:

'- Não, não fora ela!'- E maldizia a sina,

Que ela absolutamente não furtava.

Vejo, entretanto, agora, em minha cama,

Que a mim somente cabe o furto feito...

Tu só furtaste a moeda, o ouro que brilha...

Furtaste a moeda só, mas eu, minha ama,

${ }^{250}$ Idem. "Menino magro”, “Catapora” e "Presente”, p. 7 - 9. 
Eu furtei mais, porque furtei o peito

Que dava leite para tua filha."251

A relação com sua ama não evoca nenhum idílio mas, primeiramente, uma sensação de ter sido espoliado pela escrava em sua infância; já que esta roubava-lhe os "vinténs” que recebia do doutor. Porém, uma vez adulto, o autor reflete retrospectivamente, sentindo-se um tanto culpado. Merecera os furtos efetuados por sua ama, uma vez que ele lhe furtara algo muito mais precioso do que moedas: “o peito que dava leite para sua própria filha”. O arrependimento - no presente do poema - pelos furtos do passado, vem para amenizar a culpa de ter roubado (ou usurpado mediante a escravidão) o alimento da filha natural da sua escrava. Sobre esta filha natural, aliás, o autor não revela nada.

É necessário ressaltar que nas duas últimas fontes analisadas - nas quais não existia uma representação positiva do contato entre ama-de-leite negra e criança branca -, o termo mãe-preta não é utilizado. Isso porque esse leite e essa proximidade não criam vínculo algum e, tampouco, algo parecido com uma relação de maternidade.

Nos textos até agora trabalhados nesse segmento, as amas-de-leite mantiveram seus filhos naturais e "pretos" junto de si, ainda que em alguns casos tivessem de preteri-los, diante da fome do filho da família branca. Mas nem sempre esse é o destino relatado para o filho preto de outras mães-pretas. A própria “mãe Maria”, personagem já mencionada do conto de Olavo Bilac ${ }^{252}-\mathrm{e}$ mãe de criação de Nhô Amâncio -, teve seu filho natural alijado de si:

“(...) Certa noite, como ella me contasse uma historia em que se falava de creanças roubadas aos paes, perguntei: «Você nunca teve filho, Mãe Maria?» A pobre negra limpou uma lagrima, e não respondeo: mudou de conversa, e continuou, com sua meia lingua atrapalhada, a historia uma d'essas compridas historias da roça, em que ha saciperêrês e caipóras, almas do outro mundo e anjos do céo. E eu olhava-a, com uma secreta mágoa... Não que comprehendesse bem aquillo: mas a minha intelligencia de creança já adivinhava uma parte d'aquella dolorosa vida de captiva."

O destino do filho natural de Mãe Maria não é citado, “aquela dolorosa vida cativa” não permitiu que ela o mantivesse junto de si. Mas a negra, ainda que destituída de seu filho natural, realiza-se como mãe; mãe de filho branco. Assim sendo, o único filho que ela possui é aquele que a escravidão lhe deu: o filho da família branca.

\footnotetext{
${ }^{251}$ Augusto dos Anjos. "Eu" in: Toda Poesia. Rio de Janeiro, Paz e Terra, 1912/1978. p. 108.

252 Olavo Bilac e Coelho Netto. Op.cit. p. 15-30.
} 
Mello Moraes Filho, no poema “Ama de Leite”253, também trata da separação entre a ama negra e seu filho natural:

\section{AMA DE LEITE}

Vinham bater á porta e vinham para vêl-a:

Era preta e retinta; a estatura d'ella

Não era alta, não; os modos seus, ufanos,

Mostrava apenas ter dezoito a vinte annos.

- "Não foi aqui, pergunta alguém que a pretendia,

Que annunciou-se um' ama em um jornal do dia?"

"-É certo, sim senhor;" de dentro brada antiga

Matrona e se levanta. “-Olá! ó rapariga!

Vem cá na sala, vem. Póde sentar-se. É viva

No serviço de casa, e saiba que é captiva!

Experimental-a é bom; depois, della não mude:

E que ateste o doutor; se goza ou não de saúde.

Engomma, lava e cose; em tudo ella é geitosa;

Sabe agradar criança, affirmo, é carinhosa

Como bem poucas há. Em quanto aos aluguéis,

Por ser para quem é, são 60 mil réis."

- "Seu filho?!"

A pobre escrava a intristecer-se toda,

Murmura:

"Meu senhor, meu filho foi p'ra roda."

O que, num primeiro momento, chama mais a atenção nesse poema é a similaridade com a linguagem dos anúncios de escravos dos jornais da época. O texto, inclusive, trata dessa prática: anúncio e aluguel de amas de leite. Evoca todo o mercado do "leite mercenário”, conforme a denominação empregada, à época, pelos higienistas. É mediante um anúncio que o senhor bate à porta da casa, em busca de uma ama para alugar. A matrona logo responde às solicitações do “cliente” e chama a "mercadoria” em questão; provavelmente descrita desse modo no anúncio: uma "rapariga” com “dezoito para vinte anos”, “preta e retinta”, “estatura média”, “modos ufanos”. Essa primeira descrição pública revela uma concentração nos atributos físicos, e o único traço de caráter expresso é a postura da escrava: “modos ufanos”; algo próximo, talvez, de um esmero para consigo. Diante do cliente, a vendedora versa sobre as habilidades do "produto" a ser alugado. Tece, dessa forma, comentários sobre o modo como a preta realiza suas funções: "boa para o serviço da casa”, “engoma”, "lava” e “cose”, sendo muito "jeitosa” para tudo isso; além do mais, é muito carinhosa com as crianças. Fator importante e valorizado, para quem exerceria a função de ama.

\footnotetext{
${ }^{253}$ Mello Moraes Filho. "Poemas da Escravidão" in: Cantos do Equador. Rio de Janeiro, Garnier Livreiro-Editor, 1881/1900. p. 173.
} 
O cliente, ainda a checar as condições do "produto", pergunta sobre o filho recémnascido da escrava, já que ela estava aleitando. Ela, numa tristeza súbita, murmura que seu filho fora doado para a Casa dos Expostos.

A ama-de-leite, nesse relato, não pudera manter seu filho natural, retirado dela para que seus patrões ganhassem o dinheiro de seu aluguel como ama. O poeta abolicionista, ao mostrar os senhores como pessoas "interesseiras" - e revelar como a separação da escrava de seu filho natural era um verdadeiro sofrimento -, evidencia o quanto a escravidão era injusta. Além disso, mostra também como as mães escravas eram, no limite, desgraçadas, porque sequer podiam manter seus filhos junto de si. Nesse caso, a figura do filho natural da escrava toma outro lugar. Sua “expulsão” do seio materno representa a arbitrariedade da escravidão, que "elimina o natural”: a própria maternidade. Numa época de desmontagem do sistema escravista, essa imagem se afirma e ganha certa perenidade.

O filho preto da mãe-preta aparece de diferentes modos nas fontes. No entanto, é preciso salientar que à exceção de Pai João Menino, o filho natural da mãe-preta nunca é o foco, mas sempre mero coadjuvante nos textos. O objetivo principal da narrativa, na maior parte das vezes, é a relação da mãe-preta com seu filho branco; seu filho preto surge apenas como triangulação dessa relação principal. Ele destaca o arbítrio de uma relação que se realiza sem ele.

Um das razões para isso, já mencionada na críticas às fontes desse trabalho (Capítulo 2), é que os autores dessas narrativas são brancos, e pertencentes a uma “elite letrada”. Eles, portanto, representam os escravos e as figuras remanescentes da escravidão - entre elas as mãespretas - sempre envolvidos numa relação com a família senhorial, com a família branca; logo, com seu filho branco.

Nessa medida, o “fio” natural de Tia Jacinta, presente na história, é mostrado como "bem tratado” junto à família senhorial. "Dividir” o leite de sua mãe com Nho Dô é o fator responsável pelo estabelecimento de uma espécie de parentesco afetivo com seu irmão de leite. Contudo, esse filho preto não era a personagem central da história contada por “Tia Jacinta”, de modo que deixa de ser mencionado ao final da narrativa, a qual tem como desfecho um ato heróico de seu filho branco.

Outra possível explicação para esse “papel menor” atribuído ao filho negro, diz respeito às mensagens que tal personagem pode veicular. Se ele e o “filho branco" da mãe-preta 
desenvolveram algum tipo de "parentesco sociológico", pode-se extrair uma lição de "boa convivência afetiva” entre pessoas de status e cores diferentes, além da notável "liberalidade" dessa família branca. Contudo, se a descrição do filho preto é marcada pelo "signo da falta” (da mãe, de seu leite, de saúde etc.), o sentido transmitido seria o de uma denúncia da escravidão, que vitimizaria uma “criança” inocente. Este significado não seria tão “confortável” e “agradável” aos leitores brancos, que sutilmente se encaixariam no papel de culpados ou algozes.

Nos outros textos, em que os filhos naturais aparecem, a figura da mãe-preta não existe - não tece, portanto, vínculos íntimos com a casa-grande. Existe apenas a personagem da ama-deleite escrava que, mediante ameaças, é obrigada a alimentar o filho branco de sua senhora. Essa negra escrava aparece quase como uma “outra”, na acepção de que não há nenhuma relação possível entre ela e a família branca; a não ser aquela promovida pela força e violência.

Mas, essa “ama-de-leite” explorada é dotada de "humanidade” e "honra”, que ficam patentes na sua faceta de "boa mãe escrava”. Tenta preservar seu filho preto e se efetivar como mãe exemplar, mas a escravidão não permite. Esse regime - permeado por “arbitrariedade” e “força” - só consente, nestas fontes, que as escravas se realizem como mães na condição de mães-pretas, mãe-preta dos filhos dos brancos.

Essa diferença entre a mãe escrava “desgraçada” e uma mãe-preta “realizada” também está presente nas fontes, e ganha espaço em um imaginário mais alargado.

\section{Mãe-preta versus mãe escrava}

A figura da mãe-preta, tal como surgiu nas fontes, sugeria a realização de uma maternidade específica; permeada por inúmeros cuidados com seu filho branco, entre os quais a amamentação. Essa relação social era descrita com inúmeros detalhes, envolvendo uma troca de afetos recíproca entre as partes. No entanto, já na seção anterior, mostrei como começaram a surgir “amas-de-leite” que não eram “mães-pretas”, mas sim “mães escravas” de filhos pretos, que sofriam ao ter que preterir seus rebentos naturais; quando não eram completamente alijadas deles. Essas amas-de-leite são apresentadas com alguns pormenores, principalmente quando se descrevia seu desgosto por ter de abrir mão de seu filho natural diante do sinhozinho branco.

Mas o delineamento da “mãe escrava” difere um pouco dessas outra figuras: de ordinário ela é vista como uma “mãe desgraçada”. Esse tipo de representação está presente na poesia abolicionista de Mello Moraes Filho, como a que segue: 


\section{“OS FILHOS}

Elle vendera a escrava e mais as duas crias; Uma, depois da lei, só tinha quinze dias: Estatua do infortúnio, a dor mais cruciante Que a miseria levara ao seio agonisante, Foi um supplicio atroz; o derradeiro adeus, Um grito de blasphemia, um desafio aos céos!...

Tres longos annos, sim! de pranto e de martyrios Ellla os curtiu sem tregoas: - ella com seus delírios! - «Fui mãe, eis o meu crime; a condição o quer:

Não é serviço à escrava o ser também mulher?!...»

Assim pensava a triste. O duro captiveiro Lhe consumira o corpo. Esforço derradeiro A subscripção Ihe fôra: a graça soberana Da bárbara mulher, que n'isso fez-se humana!

«Aqui tens teu papel, o preço está marcado P'r'as crianças... Que a ti eu tenho destinado Que ficas fôrra. Espera, espera o teu momento, De meus netos por morte. Eu fiz meu testamento»

E quando ella sahira, horrenda de máu trato, Uma criança ao collo, outra sustendo um pranto, Aonde a compaixão errante da cidade Redime o captiveiro aos pés da caridade... Ella o encontrára e elle empalleceu de assombro; Abaixa-se ao mais velho, os dois erguendo ao hombro, Com voz já quase extincta e os olhos já sem brilhos:

— «Esmola, meu senhor! P'ra libertar seus filhos!... .» ${ }^{254}$

A escrava do poema tem relações com a casa-grande; em verdade, relações amorosas/sexuais que mantém (ou que é obrigada a manter) com seu senhor. Contudo, ao engravidar dele pela segunda vez, é vendida recém-parida juntamente com seus filhos, ficando inconsolável. Afinal apenas cumprira com as suas obrigações enquanto mulher escrava; “a condição o quer: não é serviço à escrava o ser também mulher?!...”

O poema segue mostrando o sofrimento e os infortúnios repetidos de que a mãe escrava fora vítima, terminando com uma cena que descreve as incoerências da realidade escravocrata. A escrava forra, depois de esfalfantes anos de cativeiro, vai à cidade em busca de esmolas para libertar seus filhos, e é nesse momento que encontra seu antigo senhor, rogando-lhe: "esmola, meu senhor! p’ra libertar seus filhos!...”.

\footnotetext{
${ }^{254}$ Mello Moraes Filho. Op. cit. p. 185 e 186.
} 
Ao evidenciar, em tom inflamado, o sofrimento a que estavam submetidas as mulheres escravas - as mães escravas -, e ao descrever a crueldade de seu senhor para com sua fiel servidora e seus próprios filhos, o texto assume um tom de denúncia, compreensível mediante o reconhecimento da adesão do autor à causa abolicionista. Outro ponto digno de nota diz respeito à anulação da sexualidade da mulher escrava em função da sua gravidez. Como se ao tornar-se "mãe escrava", fosse selada a sua nulidade enquanto objeto de desejo senhorial e, conseqüentemente, confirmada sua condição de “mãe desgraçada”.

Em outro poema, também de Mello Moraes Filho, intitulado "Partida de Escravos", há a descrição de uma negociação de escravos, momento no qual se observa mais um revés na vida da uma "mãe escrava":

PARTIDA DE ESCRAVOS

(...)

Sabeis o que elles passaram?

O que passam nos caminhos

Esses pobres perseguidos,

Esses filhos sem carinhos?

(...)

Conduz a escrava os filhinhos;

$\mathrm{E}$, contra o seio as mãos postas,

Caminha tendo o mais moço

Atado a um panno nas costas.

(...)

Um colloquio se deu; e, lacrimosa,

À porta, uma mulher

Implora de joelhos: - "Meu senhor, Venda a mim, se quizer!"

- "São as crianças lindas...

Vêdes? a escrava é boa;

Vendo-as por qualquer preço,

Vendo-as por cousa a tôa.

Traze teus filhos, negra!"

"Só dois? pergunta um d'elles.

E os outros? É negócio;

Aquelles? $\operatorname{sim} . .$. aquelles?

Se convier na troca,

Por mim, 'stá tudo feito;

Eu fico com os moleques

Que não servem p'r'o eito."

- "Quer a senhora apenas

Que me desfaça d'estes;

Podeis contar, aposto,

Perdi... Vós não perdestes!"

$O$ vendedor de escravos

Em pagal-os se occupa;

Os toma e do cavalo 
Suspende-os á garupa.

O' céos! a minha penna

Vacilla e se contrista:

Materno olhar segui-os...

Que desvairada vista!...

N'um circulo de fogo

Acaso o escorpião

Já viste s'estorcendo

E s'enroscando em vão?

E n'essa luta infrene,

Suprema, enfurecida,

A si mesmo voltando

$\mathrm{O}$ dardo suicida?

Assim a mãe captiva

Se debatia afflicta;

Depois, hirta, perplexa,

De pé, muda, contricta,

Retoma, um gesto horrendo...

Enfia as mãos à boca...

Coitada! A pobre escrava

Tinha ficado louca!... ${ }^{255}$

Nesse poema, a marca do infortúnio da mãe escrava já se anuncia quando o autor define os escravos como sendo "filhos sem carinhos". Logo em seguida, contrariando seu próprio veredicto sobre os cativos, Mello Moraes descreve uma “boa mãe escrava”, que caminha levando seu filho atado por um pano da Costa.

Contudo, a felicidade da "mãe escrava” não dura muito, e ela vê sua "sina” se repetir ao ter seus filhos vendidos. Com essa perda incomensurável e difícil de ser assimilada, diante da qual até mesmo o poeta se manifesta, a mãe escrava enlouquece. Pela venda de seus filhos naturais, a mãe escrava transfigura-se em "mãe desgraçada.”

Novamente, o poema busca a comoção do leitor diante do acinte que a escravidão representa, esperando a adesão desse leitor à luta pelo fim mesma instituição. Ao destacar que o regime escravista apresenta-se como um obstáculo quase intransponível ao amor da mãe para com seu filho, Mello Moraes atinge aquele que é tido como o mais singelo e verdadeiro dos amores. Assim, em sua obra, a mãe negra e escravizada é uma ótima mãe; conduz com extremo cuidado seus filhinhos que, segundo a expressão do comprador, eram "lindos”. No entanto, a escravidão não permite que ela efetive essa potencialidade de maternidade exemplar.

Vitimizando mais uma “mãe escrava”, desta vez diante de seu filho, Melo Moraes Filho continua sua denúncia da escravidão:

\footnotetext{
${ }^{255}$ Idem. p. 174 e 178.
} 
“A NOVENA

(...)

Os escravos seguiam... uma escrava

Quasi que vem de rastos!

$E$ aquece o filho que sorrindo brinca

Junto aos seus seios castos.

Vira a escada, o sol dourando o tôpo,

E sonhou com a partida;

Não queria morrer! oh não se morre

Quando se deixa a vida!

Oito dias de surra não bastavam

Aos odios canibaes!

A fazenda tem leis; são nove dias;

Era um dia de mais!

A criança tomaram de seus braços,

Que foi morder o pó;

Se erguendo cambalêa, quer seguil-a...

Tão pequenina e só!

J ungida ao poste a pobre da captiva,

Regaçam dois feitores

A manga - e estiram do chicote as pontas, Oh! que quadro de horrores!...

Gemidos abafados... pranto... sangue...

Que revoltante scena!

Rebentam chagas... Bravo! - diz um d'elles,

- São as rosas da novena!" 256

Descrevendo a escrava como "mãe exemplar" - que aquece o filho feliz junto ao seus "seios castos" - o autor ganha a indignação do leitor, diante dos castigos impingidos à negra. Além disso, a maneira brutal como a separam de seu filho - atirando-o ao chão - torna ainda mais dramático o sofrimento daquela mãe que não queria morrer, pois era responsável por aquela vida pequenina e só. A escrava novamente é representada como uma ótima mãe, que cuida de seu filho da melhor maneira possível. A escravidão aparece, porém, como limite para a concretização dessa capacidade humana inerente à mulher cativa.

A representação da mãe escrava aqui discutida aparece encompassada por sua categorização social marcada pela escravidão. Desse modo, as “mães escravas” sequer são nomeadas nas fontes. Sua descrição trata das situações em que o arbítrio da instituição, assegurado pela violência, faz-se valer. Causa no leitor uma compaixão pelo sofrimento alheio, 
sobretudo pela dor da “desgraçada mãe escrava”, que se liberta e luta pela libertação de seus filhos - frutos esses dos abusos a que fora submetida por seu senhor -, daquela que vê seus filhos sendo comprados e daquela que apanha diante de seu filho, temendo morrer e deixá-lo abandonado.

A figura da "mãe escrava” interliga-se a uma denúncia da escravidão e não se confunde com a representação da "mãe-preta” ou da "ama-de-leite”. Isso porque essas últimas, ao adentrarem a casa-grande e tornarem-se pólos de relações pessoalizadas com a família patriarcal branca, ganham uma feição mais humana, acrescentando maior indeterminação ao seu status de escravas; afinal, compartilhavam do cotidiano e de algumas regalias na casa de seus senhores.

Mas a “mãe escrava” destes poemas, ainda que esteja subsumida à sua categoria social, é dotada de "humanidade” e de "virtude"; essas se expressam em sua potencialidade para ser "mãe exemplar”, sempre carinhosa e preocupada com suas “crias”. A escravidão aparece, assim, como limite para a efetivação dessa maternidade, que é a única relação social própria à escrava não mediada pelos senhores brancos.

A descrição da “mãe escrava”, feita nesses poemas escritos por um abolicionista branco é, portanto, um diagnóstico sobre a impossibilidade - ou sobre as extremas dificuldades - de existência de uma família escrava.

Não obstante, numa reflexão retrospectiva em relação à figura da mãe-preta, percebe-se que ela tampouco é ego de um parentesco. Ao contrário, encaixe-se nestas fontes, sempre na família patriarcal branca. Ela é “agregada” ou incluída num "parentesco afetivo” que tem como núcleo essa mesma família branca. Isso fica perceptível quando se retorna às fontes: “Tia Jacinta” teve seu marido vendido, e seu filho desaparecia ao longo da história; ela, depois de livre, passa a viver como agregada na família de seus antigos senhores, chamando os descendentes desta família de “filhos”. "Mãe Maria” também não tinha nenhuma relação social própria, senão aquelas com seu filho branco ("Nhô Amâncio”) e a família respectiva. "Mãe Preta”, que trata de seus filhos brancos doentes, tem sua vida resumida aos cuidados e carinhos com os filhos de leite, e eles são a única relação social que a escrava possui, de modo que se sacrifica por eles, sem nenhum pesar. A “Mãe Preta” - do prólogo do livro infantil de Luiz Demétrio Juvenal Tavares - também vive a criar os filhos da "sinhára branca”. E a sacrificada “Mãe Preta” da poesia de Murillo Araújo também se relaciona somente com as crianças brancas das quais cuida.

\footnotetext{
${ }^{256}$ Idem. p. 180 e 181.
} 
Nas fontes até aqui trabalhadas, a maternidade preta - seja de filho branco, seja de filho preto - é sempre liminar; não se constituindo como ego de parentesco algum. A “mãe escrava”, em função das agruras da escravidão, encontra-se impossibilitada de construir uma família escrava; a “mãe-preta”, por sua vez, é sempre “assimilada” de maneira específica no núcleo familiar branco e patriarcal. Essa maternidade preta, tanto do filho branco como do preto é, porém, invariavelmente exemplar; como se as mães negras tivessem “vocação” para executarem o papel de mãe. Mas, como diz o ditado, toda regra tem sua exceção. É sobre essa rara exceção que discorro a seguir.

\section{Mãe-preta e a magia}

Dentre o material selecionado, encontra-se uma “mãe escrava” que não se conforma em ser “mãe desgraçada”. Quando vislumbra a proximidade de seu infortúnio, resolve evitá-lo, antes que este a atingisse. Esse enredo está presente no poema “A Feiticeira”, composto por Mello Moraes Filho ${ }^{257}$ :
“A FEITICEIRA
É noite! E' meia noite! A selva brava Resona ao vento solto na folhagem!...
Tudo é paz e descanço! Só a escrava
Sente a attração do abismo e da voragem!
Um passo, um passo mais, ao prado aberto
Ella pede o veneno, a morte ás flores.
Horror! ser mãe e ver-se n'um deserto!
Viva! - orphão seu filho aos seus amores!...
Oh! Que longo pensar! Grilhões pesados
Do captiveiro arrasta a vida inteira!
Em torno - a prole vil dos desgraçados;
Pr'a tornal-a feliz - foi feiticeira.
Sim! Na calada das vigílias calmas, Quando a onça boceja, ao abandono,
Fazia ella partir libertas almas
Aos succos acres que produzem somno.
(...)
Ao candieiro aceso da senzala,
Ergue-se e espreita a solidão infinda;
A feroz crueldade o céo abala,
E o ódio no seu peito augmenta ainda!
A porta abriu: ninguém seu plano entrava!
Ella sabe: a planície é vasta e núa!

${ }^{257}$ Idem. p. $197-199$. 
Escolhe plantas a Medéa escrava,

Banhando o rosto negro á luz da lua.

Raízes e cipós ella os conhece,

As soleneas fataes, a strychnina;

Pé ante pé deslisa, - a grama cresce;

$\mathrm{E}$ as sementes espalha na campina.

(...)

Porém, silencio! Eil-a, eil-a que torna...

Uma velha... a infância... ai! pobresinhas!

Do seio um philtro arranca, ao labio entorna

D'alvorada da dor - das criancinhas.

Depois, sumiu-se; entrou n'esse aposento

Dos captiveiros do eito, ó sina horrenda!

Da justiça de Deus o algoz cruento,

- A negra feiticeira da fazenda!"

O poeta, ao fazer uma metáfora em que associa a escrava velha com a figura mitológica grega da “Medéia”, já revela que essa personagem não era uma “mãe exemplar”. A protagonista do mito grego, descrito por Eurípedes, matou seus próprios filhos, num ato premeditado, para se vingar de seu marido, Jasão. Aqui, a “Medéia escrava” - numa atitude igualmente planejada envenena suas “criancinhas”. A premeditação fica evidente na passagem: “ninguém seu plano entrava”.

Contudo, no poema, tal ato cruel não é justificado por uma “maldade” ou "crueldade” inata à escrava. A culpada por este crime, para o autor abolicionista, era a própria escravidão. Esta instituição “abominável” corrompera a “mãe escrava”, que vivia em "horror”, que “era mãe, mas via-se num deserto", que tinha "filhos órfãos de seu amor” e que produzira uma "prole vil de desgraçados”. Para ter alguma “felicidade” em cativeiro, tornara-se “feiticeira”.

Apenas a "feitiçaria”, aqui relacionada à negra escrava, seria capaz de promover um ato tão paradoxal: a "Medéia escrava” matava seus filhos, crendo que lhes fazia um bem. A negra acreditava que assassinar "as pobrezinhas” era equivalente a manumití-las, tal como expresso no verso: “fazia ella partir libertas almas”. Na poesia, por mais ambíguo que pareça, a "negra feiticeira”, segundo sua própria lógica, seria uma "boa mãe”.

A “feitiçaria” é descrita como “perigosa”, “poderosa” e, portanto, liminar. Esse poder sobrenatural, segundo o texto de Mello Moraes, adviria de um conhecimento profundo das plantas. Trata-se assim, de uma "natureza que mata”: "raízes e cipós” eram "as soleneas fatais”, “a strychnina”. 
No poema “Olhado”, composto por Jorge de Lima ${ }^{258}$, há uma “mãe-negra” - meio “maga”, meio católica - que protege as crianças contra “males espirituais”:

“OLHADO

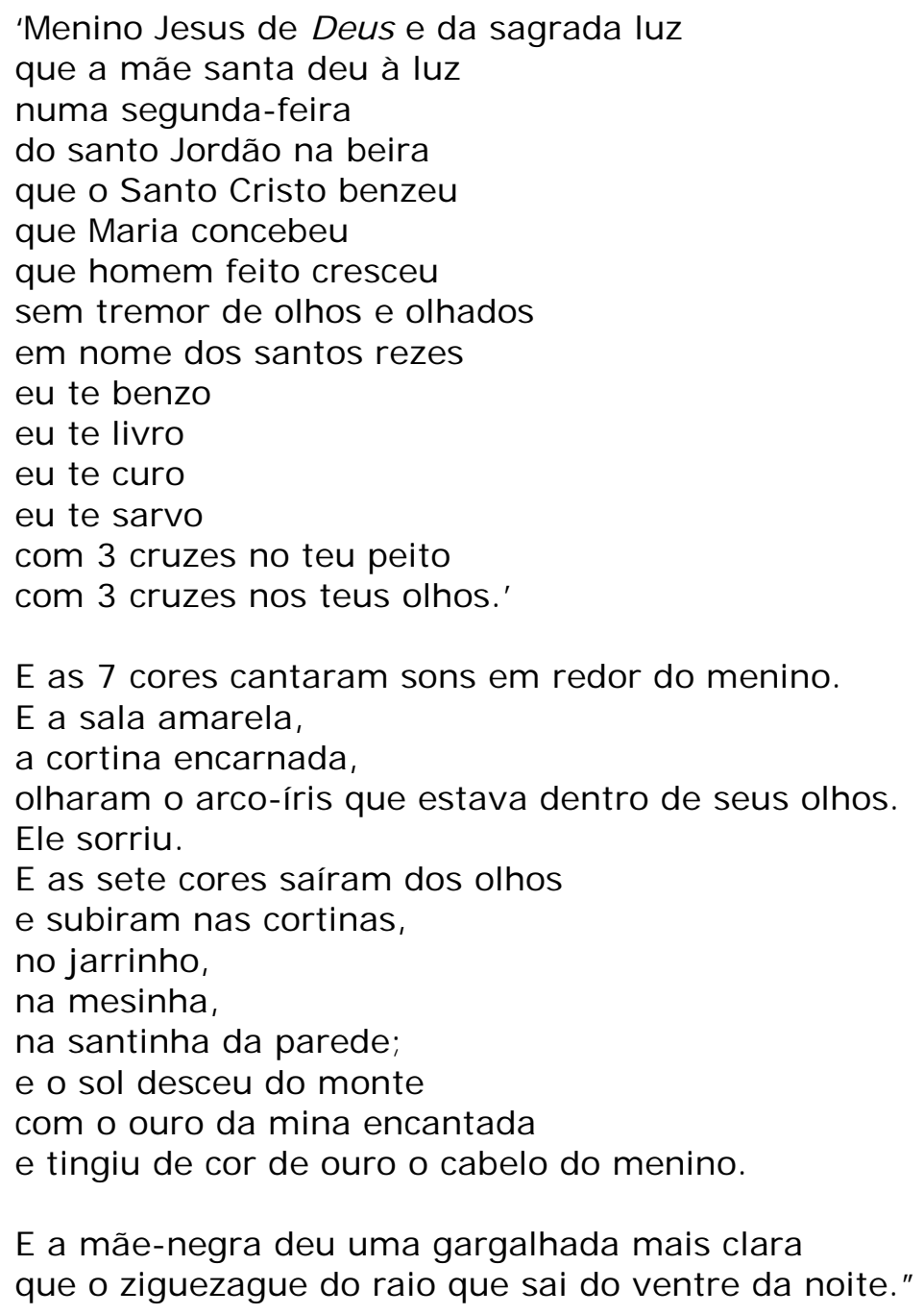

A “mãe-negra”, descrita no poema, é uma espécie de "benzedeira”, que retira ou protege os pequenos contra o “olhado”. Depois de "livre”, “benzido”, “curado” e “salvo”, o menino voltou a sorrir e a ser uma criança vivaz. A “mãe-negra”, numa espécie de "benção-exorcismo”, realiza um ritual mágico mesclado com o catolicismo. Surge, então, um catolicismo místico e popular, ou uma feitiçaria sincretizada com o cristianismo.

No entanto, ainda que no poema a negra utilize seus poderes mágicos para o bem, ela surge novamente enquanto figura liminar: sua "gargalhada mais clara que o raio" a aproxima da figura da bruxa, que também pode usar os seus poderes para o mal.

${ }^{258}$ Jorge de Lima. "Poemas" in: Poesia Completa vol. I. Op.cit. p. 93 
Por meio de uma exceção, a representação da maternidade negra - como sendo invariavelmente exemplar - foi tensionada. Essas “mães falíveis”, não são descritas de maneira tão “humana” e “virtuosa” como eram as “mães pretas”, as “amas-de-leite” e as “mães escravas”. Elas são, eminentemente, liminares em função de seus poderes mágicos. Dessa forma, elas se afastam das descrições “mais brancas e civilizadas” feitas das mães-pretas. "Feiticeira” ou “benzedeira”, ambas podem usar seu domínio do sobrenatural tanto para o bem, quanto para o mal. Quando exercem o bem, elas são queridas e prestam serviços mágicos para os brancos - o menino bento por “mãe-negra” tinha o cabelo “cor de ouro” - mas permanecem suspeitas, como as bruxas, pelos seus poderes.

A “Medéia escrava” utilizou seus feitiços para matar os próprios filhos, acreditando com isso, poupar-lhes da vida “desgraçada” de escravos. Esta atitude paradoxal - ao mesmo tempo execrável e compreensível - é justificada pela influência nefasta da escravidão na moral humana, na moral do escravo.

\section{Mãe-preta e Pai-joão: personagens simétricos}

Nas fontes, sempre próxima da descrição da mãe-preta, encontra-se a caracterização de pai-joão. A representação dos dois é semelhante: ambos são negros velhos (escravos ou exescravos) que têm uma relação muito próxima com a família de seus senhores; trabalham no ambiente doméstico, sobretudo "pajeando” as crianças - que lhes querem um bem extremado ou ainda, cozinhando. A diferença marcante existente entre esses personagens simétricos é o gênero. Em função desse ponto diacrítico é que se alteram os termos do "parentesco consuetudinário”: mãe-preta e pai-joão. Em certas fontes, pai-joão e mãe-preta possuem até mesmo parentesco entre si.

Uma personagem caracterizada de modo impressionantemente próximo da mãe-preta está presente no poema “O Pai José”, de Luis Delfino dos Santos ${ }^{259}$ :

“O PAI JOSÉ

Era um pretinho velho o bom do escravo,

Mas velho, como era,

Vinha-Ihe da alma exalação perene

Da eterna primavera.

${ }^{259}$ Luiz Delfino dos Santos. Poesia Completa. Florianópolis, Academia Catarinense de Letras, 2001. Tomo II, p. 268 a 271. 
Não conhecia o peso das algemas:

Sua alma era a piedade,

Suspiro às vezes triste e involuntário

De mágoa e de saudade.

Por entre fachos aurorais, às vezes

Num olhar fundo e longo,

Via fugir outeiros, vales, campos.

Choças, e enfim o Congo.

Fumo...visão...saudades!...Em torno estava

Loura, chilreante e bela

A matinosa multidão, enquanto

Mexia a panela.

Era o rei da cozinha; e a dominava

Com nobre desempenho:

Que ondulante fumaça enovelava

O seu cheiroso reino!

Tinha aquele portento nas mãos negras

A mágica vergasta:

Com a colher, dizia a um, e a outro:

Nhonhô, afasta...afasta...

Fingimos fome... No país das fadas

Não há melhor cozinha:

Não cheira tanto, como estou lembrado,

Que ali cheirava a minha.

E o pai J osé, mostrando que ralhava, Inda fidelidade

Guardada à nossa mãe, lá vinha um prato, Com grande hilaridade

Recebido por nós: estas delícias,

Da vida ornato e enfeite,

Ele nos dava, como a aurora aos montes

Mel oiro e branco leite.

E aqui jaz nesta rasa sepultura,

Sem pedra e sem letreiro,

O bom amigo, o pai José, o escravo...

O nosso cozinheiro!

Flores de gratidão derramo agora

Onde ele está sepulto:

São verdadeiras lágrimas, que choro

Sobre este chão inculto.

Ai! quando ele morreu, não levou tudo Para a cova consigo:

Ai! que saudades nos deixou o negro...

O nosso pobre amigo!... 
Sob essa crosta bárbara e sombria,

Que eterna primavera,

Que alma cheia de luz e de perfumes

Lá dentro não coubera!...

Quando, para estudar, da loira turba

Algum de nós fugia,

Emigrando, qual prófuga andorinha,

Que tristeza o invadia...

Chorava... Até que um dia já de volta

Chegava o senhor-moço...

Era um dançar de louco, em torno dele,

Um curvar de pescoço,

Bater de palmas, dar com os pés em terra,

E a tudo, que ele via,

Ao céu, ao sol, aos muros, e arvoredos

$A$ bênção ele pedia.

Já Ihe caíam lágrimas dos olhos,

Já ria, já gritava:

Era um vulcão, que a luz de mil auroras

Num instante entornava!

Veio a morte um de nós buscar um dia,

Que grandes gritos doudos!

Parecia chorar pelo universo,

Por si, e por nós todos!...

A dor profunda lhe abalava a entranha:

Ele a mostrava em tudo:

Chorava a dor, nas lágrimas chorava,

Chorava-a o lábio mudo.

Adeus, meu pobre preto, adeus! - Contigo

Minha infância querida

Dorme também da mesma relva à sombra,

Que te cobre a jazida.

Esta saudade adorne-te o sepulcro,

Porta da liberdade:

Ninguém ossário encheu de amor tão grande,

E tão grande piedade!..."

Nesse longo soneto, o escravo "Pai José” é lembrado com muito saudosismo pelo poeta, que escreve sobre essa personagem de sua infância. O “cozinheiro negro” tinha uma relação muito íntima com a família branca, sobretudo com suas crianças. Ele possuía um amor “extremado” por elas e ficava "triste” quando viajavam para estudar. Mas quando retornavam, eram “incrivelmente” festejadas por ele: “dançava”, “curvava o pescoço” - talvez, numa atitude 
que significava reverência ao seu superior “nhonhô”, "batia palmas”, “pedia benção à natureza” e chorava.

Quando um de seus "nhonhôs” morreu, o "sentimental” escravo deu "gritos doidos”, e chorou muito. Mas esse amor que "Pai José” tinha pelas crianças brancas era retribuído na mesma medida. Quando o escravo morreu, os pequenos (entre os quais está o autor do poema) “derramaram lágrimas”, “depositaram flores em sinal de gratidão” e sentiram “muitas saudades”.

"Pai José” é descrito, dessa forma, como um escravo “amoroso”, “piedoso” e "fiel” a sua senhora. A família branca do soneto reconhecia essas qualidades do cozinheiro, de modo que ele “não conhecia o peso das algemas”. Era “ameno”, portanto, o jugo a que estava submetido "Pai José”. Ele, no entanto, sentia “os pesares” de sua condição escrava, que ficam perceptíveis nas “saudades do Congo” e nos “suspiros tristes de mágoa”.

O "Pai José” do poema é tão “virtuoso" - com sentimentos puros - que, no quesito moral, se aproxima muito dos brancos. Trata-se assim, de uma figura muito próxima do "preto de alma branca”. No entanto, essa semelhança com os brancos (e a intimidade com eles) não rompe os limites da hierárquica instituição escravista; de modo que "Pai José” morre escravo. Em outras palavras, a intimidade e o afeto não superam a diferença e a hierarquia.

A personagem de "Pai José” é tão próxima à da mãe-preta que, por vezes, tem-se a impressão de não se tratar de um homem, tal como se poderia definir na literatura de então. Ele é tão sentimental quanto uma mulher, além de dançar, ter uma relação muito próxima com as crianças e ser demasiadamente fiel. Todas essas características remetem a um universo “feminino”, e fazem com que "Pai José” perca parte de sua "virilidade”. Trataria-se, nesse sentido, de uma figura paterna extremamente maternal.

Na seguinte poesia, "Pai João", escrita por Jorge de Lima ${ }^{260}$, há uma relação de parentesco entre o negro velho e a ama-de-leite. Tratam-se de pai e filha:

“PAI J OÃO

Pai J oão secou como um pau sem raiz. -

Pai J oão vai morrer.

Pai João armou nas canoas. -

Cavou a terra.

Fez brotar do chão as esmeraldas.

Das folhas - café, cana, algodão.

Pai João cavou mais esmeraldas

Que Pais Leme.

A filha de Pai João tinha um peito de

${ }^{260}$ Jorge de Lima. "Poemas" in: Poesia Completa vol. I. Rio de janeiro, Nova Aguilar, 1927/1974. p. 110 e 111. 
Turina para os filhos de ioiô mamar:

Quando o peito secou a filha de Pai J oão

Também secou agarrada num

Ferro de engomar

A pele de Pai João ficou na ponta

Dos chicotes.

A força de Pai J oão ficou no cabo

Da enxada e da foice.

A mulher de Pai J oão o branco

A roubou para fazer mucamas.

O sangue de pai J oão se sumiu no sangue bom

Como um torrão de açúcar bruto

Numa panela de leite. -

Pai João foi cavalo pra os filhos do ioiô montar.

Pai J oão sabia histórias tão bonitas que

Davam vontade de chorar.

Pai João vai morrer.

Há uma noite lá fora como a pele de Pai João.

Nem uma estrela no céu.

Parece até mandinga de Pai João."

Nesse poema, “Pai João” é descrito como um escravo que tinha relações próximas com a família senhorial branca, inclusive com os herdeiros dela. Contava histórias para as crianças e brincava de cavalinho com elas. Uma brincadeira que evidenciava o caráter hierárquico desse vínculo, também afetivo: “Pai João foi cavalo pra os filhos de ioiô montar”. Aliás, é na hierarquia e na exploração, promovidas pela escravidão, que está o foco principal do poema.

Esta instituição "sugou” tudo de "Pai João", deixando-o "seco", e à beira da morte. A escravidão, ainda, roubara-lhe a mulher para “mucama”, a filha para "ama-de-leite” e “engomadeira”, a pele “pela ponta dos chicotes”, a força “pela enxada e foice” e seu sangue. Em resumo, no poema, a escravidão promoveu um esgotamento físico do negro velho, usurpando-lhe também sua própria família - levando-o, conseqüentemente, a um esgotamento humano -, os únicos laços sociais próprios que ele conseguira tecer.

Mas o trabalho - ainda que escravo - de “Pai João” edificara as riquezas do país; fosse mediante as esmeraldas que cavara, fosse mediante as lavouras que cultivara: café, cana e algodão. Ele, portanto, se sacrifica - por meio do trabalho e pela doação de sua família - para a construção da pátria. Era um ato de sacrifício de si próprio, que fica expresso na passagem em que “o sangue de Pai João” - “um torrão de açúcar bruto” - se dissolve no “bom” sangue dos brancos - uma panela de leite. 
No poema há, portanto, vestígios de uma certa mestiçagem, mais precisamente uma assimilação do elemento negro, pela usurpação de sua pessoa, de seu sangue, de suas forças, de seu trabalho, de sua família. Há uma assimilação mediante a escravidão.

Um “Pae João” que trabalha arduamente, constituindo várias riquezas para a pátria, está presente no seguinte poema, de autoria de Cyro Costa ${ }^{261}$ :

“PAE J OÃO

Do taquaral á sombra, em solitária furna,

Para onde, com tristeza, o olhar curioso, alongo,

Sonha o negro, talvez, na solidão nocturna,

Com os limpidos areaes das solidões do Congo...

Ouve-Ihe a noite a voz nostalgica e soturna,

Num suspiro de amor, num murmurejo longo...

E o rouco, surdo som, zumbindo na cafurna,

É urucungo a gemer na cadencia do jongo...

Bendito sejas tu, a quem, certo, devemos

A grandeza real de tudo quanto temos!

Sonha em paz! Sê feliz! E que fique de joelhos,

Sob o fulgido ceo, a relembrar, magoado,

Que fructos do café são glóbulos vermelhos

Do sangue que escorreu do negro escravizado!"

“Pae João” surge, no poema, como um “negro solitário” que tem saudades da África, mais especificamente dos "limpidos areaes do Congo”. E nessa rememoração da pátria-mãe, o negro velho evoca elementos da cultura africana - "cadencia do jongo”, “a cafurna” e o "urucungo” descritos de um modo "exótico”.

Ele não é caracterizado como escravo, mas é certo que o era; caso contrário não se desolaria em saudades de sua terra natal, a qual fora obrigado a deixar.

O texto, posterior à Abolição, traz em seu desfecho uma condenação inflamada da escravidão: "fructos do café são glóbulos vermelhos / do sangue que escorreu do negro escravizado!”. Mas o autor reconhece também o trabalho realizado pelos escravos na terra a que foram trazidos: "bendito sejas tu, a quem, certo, devemos /A grandeza real de tudo quanto temos!”. A personagem de "Pae João” mostra-se, portanto, ambígua; sua condição como cativo é conotada negativamente. Porém, Cyro Costa reconhece o escravo como um “bravo”, como um “trabalhador” que deu nos legou (a nós e ao narrador) a grandeza de tudo quanto possuímos. Há,

${ }^{261}$ Cyro Costa. Terra Promettida. Rio de Janeiro, José Olympio Editora, 1938. (Compilação póstuma de sua obra publicada nos jornais entre 1889 e 1937) p. 159 e 160. 
desse modo, certa louvação do escravo sacrificado, concomitante à uma condenação da escravidão.

Na poesia que segue, esses mesmos elementos da cultura africana ressurgem, ainda que de outra maneira. Além disso, a descrição de "Pai-João" traz à tona, novamente, a imagem do escravo sofredor. Mas aqui, o cativo também se rebela. O poema chama-se "Sangue Africano”, e foi composto por Cassiano Ricardo ${ }^{262}$ :

\section{“SANGUE AFRICANO}

Ó meu Pai-João, por que choraste?

Olhei o negro velho, ao clarão da fogueira,

e pareceu-me ver a noite em forma humana;

e pareceu-me ver a saudade africana

crucificada numa noite brasileira...

Lá fora, no terreiro da fazenda, a dança trágica e noctâmbula dos pretos, de sarabanda em bamboleios de perna bamba no resmungo sem fim do bumbo ou do urucungo no arrasta-pé grosseiro e fúnebre do samba que retumba na noite lúgubre que descamba: é o chôro surdo e entrecortado do batuque, no pate-pé que enche de assombro o próprio chão... E a lua alvíssima derramada na restinga pinta cal tôda a paisagem de carvão; nas casas de sapé, nas moitas de caatinga, pinga na sombra qualquer coisa de mandinga e assombração.

Ó meu Pai-João, eu sei de tôda a tua história. Quando o navio alçou o pano ao vento da África, algemaram-te as mãos em cadeias de chumbo; e, no porão, olhando os astros, noite em fora, quanta vez escutaste o longínquo retumbo do oceano a estrangular as praias sem aurora como um negro quebrando as cadeias de chumbo!

Depois... os cafezais, os eitos, ó contraste! Por entre moitas, espraiados e barrancas, baixou a noite dos cativos e ficaste crucificado numa cruz de estrelas brancas!

Depois, fugiste ao cativeiro; fundaste, à sombra dos palmares, tua cidade livre, e com o teu próprio sangue semeaste a redenção do solo brasileiro.

Depois... a tua redenção.

${ }^{262}$ Casssiano Ricardo. "Vamos caçar papagaios (1926)" in: Poesias Completas. Rio de Janeiro, Editora José Olympio, 1957. p.72 e 73. 


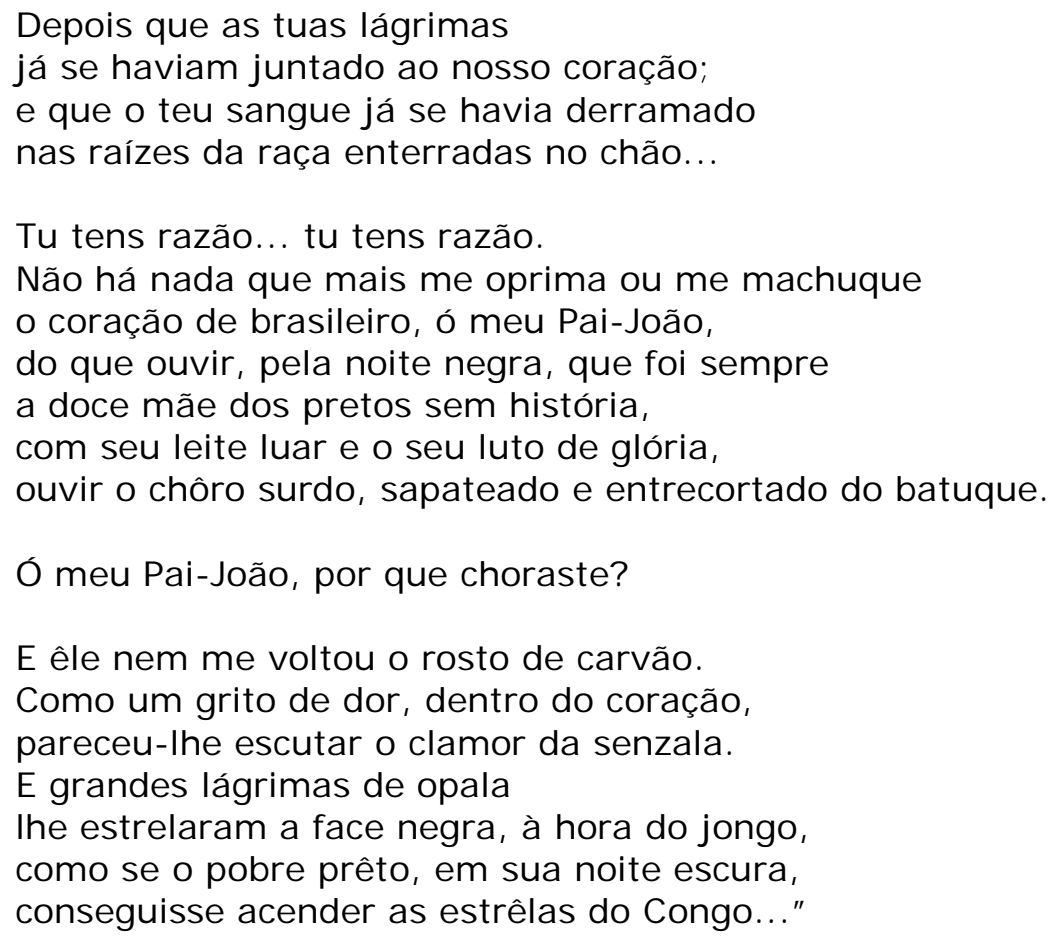

Tu tens razão... tu tens razão.

Não há nada que mais me oprima ou me machuque

o coração de brasileiro, ó meu Pai-João,

do que ouvir, pela noite negra, que foi sempre

a doce mãe dos pretos sem história,

com seu leite luar e o seu luto de glória,

ouvir o chôro surdo, sapateado e entrecortado do batuque.

Ó meu Pai-João, por que choraste?

E êle nem me voltou o rosto de carvão.

Como um grito de dor, dentro do coração,

pareceu-Ihe escutar o clamor da senzala.

E grandes lágrimas de opala

Ihe estrelaram a face negra, à hora do jongo,

como se o pobre prêto, em sua noite escura,

conseguisse acender as estrêlas do Congo..."

O poema narra o percurso “trágico” do “Pai-João” cativo, desde sua escravização na África, sua vinda forçada ao Brasil, sua "crucificação” no eito, sua tentativa de revolta e sua derradeira redenção à pátria. A escravidão é descrita como "violenta” e "exploradora”, causando saudades da África. No entanto, tanto a escravização, quanto o trabalho no eito são metaforizados na “crucificação redentora”, que anuncia o sacrifício de “Pai-João” pela terra que o escravizou.

O escravo é tido como um "bravo" que se revoltou e fugiu; em seguida, criou sua cidade livre: Palmares. Mas Palmares e "Pai-João", mediante a força do estado escravista que os circundava, são obrigados a se render. Essa rendição acaba por tornar-se, na voz do poeta, em redenção. O escravo morto redimiria a própria pátria e a si mesmo.

Nesse auto-sacrifício do escravo há, também, certa conotação de mestiçagem: suas “lágrimas” e seu “sangue” já se haviam misturado aos da pátria, e as "raízes de sua raça já estavam profundamente enterradas no chão”.

Os elementos africanos (bumbos, urucungos, batuques, mandinga) revelam, igualmente, essa mestiçagem; não mais de “raça” ou “sangue”, mas de culturas. Esses “rasta-pé”, “samba”, “patê-pé”, não são mais remetidos às lembranças da África; eles se realizam no Brasil, no terreiro da fazenda onde os escravos trabalhavam. 
Assim, é possível dizer que “Pai-João” se oferecera - ainda que obrigado pela escravidão - em sacrifício por esse país ao qual ele se mescla, ou melhor, se dilui, por meio do trabalho, do sofrimento, do sangue, das lágrimas e da cultura.

Pai-joão é um personagem que apresenta muita semelhança com a figura da mãe-preta, tendo até mesmo, em algumas fontes, certo parentesco com essa negra velha. Essas duas representações tratam de negros velhos - escravos ou remanescentes da escravidão - que trabalhavam cotidianamente na casa senhorial, por vezes cozinhando, por vezes pajeando os filhos de seus senhores. Desta relação íntima com as crianças da família patriarcal surge um carinho recíproco. Deste modo, como no caso de "Pai José”, os escravos são tão "virtuosos” e honrados que se aproximam de uma moral branca. No entanto, essa intimidade e afeto não rompem com a hierarquia e a diferença pressupostas na escravidão. Nas fontes, o máximo que “pais-joões” e “mães-pretas” conseguem são privilégios dentro do arbítrio escravista, como “não conhecer o peso das algemas”.

Nesses poemas também fica evidente o sacrifício cotidiano realizado por pai-joão; seja para a felicidade de seus pequenos “senhores”, seja para a edificação da pátria. Estes "sacrifícios” pela pátria, presentes nas poesias de Jorge de Lima, Cyro Costa e Cassiano Ricardo, estão também coadunados com o contexto histórico-cultural. Eles foram compostos nos anos 19201930, de modo que estão afinados com a memória oficial, a qual insistia na idéia do "mestiço". Nos poemas mencionados, se assumem, portanto, as contribuições dos negros e escravos para a formação de uma pátria mestiça.

Desse modo, “pai-joão”, na roça, por meio de seu trabalho, se imola para produzir as inúmeras riquezas do Brasil. Mas essa oferta da personagem em holocausto, para a estruturação da pátria, é também a redenção da "raça” negra. Isso porque, é mediante o trabalho escravo que os negros - e pai-joão - são recuperados como uma das raças-culturas que contribuíram para o nascimento do país mestiço. Nesse contexto, as alusões ao "sangue” e “suor” de pai-joão, que se misturam à terra, fazem mais sentido, revelando a origem desse país misturado.

“Pai-joão” é, nesses textos, um personagem que, por meio de um ato honroso - seu autosacrifício - colaborou para o nascimento de uma civilização miscigenada. Tratar-se-ia, nessa medida, de um elemento negro e civilizador por excelência.

\section{Mãe-preta e o sacrifício pela pátria}


Em grande parte das fontes, a figura da "mãe-preta” surge intrinsecamente conectada ao sofrimento. Essa situação justifica-se em parte pelo estatuto da escravidão, que impinge à escrava um desgaste extremo de seu corpo. Essa avaria - de duplo caráter, espiritual e físico - também se liga ao seu papel de “mãe de criação”; “mãe afetiva” e “mãe social” de filhos brancos, submetida à mais cruel escravidão: a escravidão do amor.

Mello Moraes ${ }^{263}$ mostra, mais uma vez, os entraves paradoxais promovidos por essa instituição de arbítrio, que não veta a possibilidade de uma convivência afetiva:

\section{“MÃE DE CRIAÇÃO}

Era já velha a misera pretinha:

Tão extremosa como as mães que o são:

Era escrava, porém que o amor que tinha

Àquelle a quem foi mãe de criação!

Cuidava tanto delle... Quando o via

Dos estudos chegar, chegar-se à ella,

Parece que a ventura se embebia,

Como um raio de luz, nos seios della.

Seu filho lhe morrera em tenra infancia...

A sorte dos captivos é a dos revezes!

Ella o criara, e d'alma n'abundancia

O consagrara filho duas vezes

Quizeram libertal-a; a liberdade

Tomou como uma offensa e não cedeu;

Depois... «Minha senhora, é caridade

Não me apartar do filho que me deu.»

Scismava alegre tanta scisma vaga, Pedia a Deus por elle tanto, tanto, Que só de crêl-o ausente era aziaga

A hora que o furtava ao seu encanto.

Mas os tempos passaram; tudo acaba;

Nem no sonho feliz o foi sequer!

Ha filhos-reptis que cospem baba,

Lethal veneno a um seio de mulher.

Elle o fizera. Áquela que os vagidos

De seu berço acudiu, ó mães bondosas,

Que velára, acalmando os seus gemidos

De criança, nas noites dolorosas,

Levou-lhe ao rosto a mão matricida!...

A pobre velha lá mordeu o chão:

— «Com meu sangue de escrava dei-lhe a vida...

${ }^{263}$ Mello Moraes filho. Op.cit. p. 194 e 195. 
à seus pés, meu senhor... perdão! perdão!»"

A escrava, que perdera seu “filho natural”, nutria pelo "sinhozinho branco” um verdadeiro amor maternal, que não só compensava-lhe a perda, como ajudava-a a superá-la. Aqui se confirma a vocação da mãe-preta como a essência da maternidade a ser efetivada tanto por meio de filhos brancos quanto pretos. No poema, a companhia de seu filho de criação, tão bem quisto, “enchia-lhe os seios de ventura”. Uma metáfora que revela que se a escrava não fora sua ama-deleite fora, ao menos, uma “ama-de-afeto”.

Em reconhecimento aos sentimentos nutridos pelo filho da família patriarcal, seus senhores esboçam o desejo de libertá-la, mas tal proposta é tomada como uma ofensa pela escrava. Ao rechaçar essa oferta, a mãe-preta nega, em verdade, a troca paternalista. Reafirma, portanto, que seus sentimentos pelo menino não visavam uma ascensão dentro do lar mas eram, tão somente, “desinteressados e sinceros”.

Esse amor “incondicional” de mãe foi, no entanto, retribuído com ingratidão pelo filho de criação, que acaba por castigá-la. A ama, ainda que em sofrimento, pede perdão ao seu "senhor”, numa atitude de extrema resignação, promovida pela “escravidão do amor”. Mas ao pedir perdão ao seu senhor, é possível que a ama também se referisse ao "Senhor Deus”, a quem era muito temente. De ordinário, ela rogava a Deus por seu filho branco e, ao apanhar, diante dos pés do agressor, pediria perdão ao Senhor, pelos atos de seu senhor e filho terreno. Realizaria, portanto, uma atitude mimética ao Cristo na cruz, que pediu a Deus que perdoasse aqueles que o crucificavam. A “mãe de criação” da poesia, no limite, sacrifica-se pelo filho branco e pelas mãos desse seu filho.

A escravidão do amor e o sacrifício de si pelo filho branco também estão presentes no poema de Cyro Costa ${ }^{264}$ :

“MÃE PRETA

Lugubre, acaçapada, espiando no ermo, á beira

Do açude da fazenda, a lua côr de opala,

Com sussurros de reza ou rumores de feira,

Via-se, num quadrado, a sordida senzala...

Sobre um velho giráo furado de uma esteira,

Eil-a, embalando ao collo - e com que amor na fala! -

O <sinhôzinho branco>, a quem se dava, inteira,

Até que, adulto, fosse, um dia, vergastal-a!

Soffreu como ninguém! Com fervor nunca visto,

Persignava-se ao ver ceos azues e montanhas:

${ }^{264}$ Cyro Costa. Op. cit. p. 161 e 162. 
<Louvado seja Deus Nosso Sinhô - Suns Christo!>

$\mathrm{Na}$ escravidão do amor, a criar filhos alheios,

Rasgou, qual pelicano, as maternaes entranhas,

E deu, á Pátria livre, em holocausto, os seios!"

Desde o início do poema, a descrição da "Mãe Preta” é feita de maneira triste. Ela encontra-se "lúgubre e acaçapada”, a ver “a sórdida senzala”. A personagem é uma escrava, uma escrava absolutamente abnegada, "havia sofrido como ninguém” e "persignava-se ao ver ceos azues e montanhas”, dizendo: “Louvado seja Deus Nosso Sinhô - Suns Christo!”. Ou seja, num ambiente inóspito e de sofrimento, “Mãe Preta” agradece pelas bênçãos cotidianas da natureza que "Deus" lhe proporcionara. Ela vivia em uma atmosfera que também era marcada por um certo misticismo católico, presente nos “sussurros de reza”. Essa religiosidade tem, inclusive, o tom popular expresso em "Sinhô" e "Suns Christo".

A escravidão à qual "Mãe Preta” estava submetida era peculiar, e também revela o altruísmo da personagem; tratava-se da “escravidão do amor”. Subjugada pela violência da instituição escravista, a “preta” transformava o “arbítrio” em amor. Mesmo que obrigada a cuidar do "sinhozinho branco", ela o fazia “com amor na fala” e "se dava inteira” por esse seu "rebento afetivo”. Em outras palavras, "Mãe Preta” transfigurava os deveres que era obrigada a cumprir em uma obrigação moral própria; daí não ser apenas escrava de seu senhor, era escrava do amor que ela própria sentia por seu “filho branco". Ele, contudo, retribuiu-lhe com “ingratidão” e “injustiça”, subentendidos na passagem - “Até que, adulto, fosse, um dia, vergastal-a!”.

A abnegação da personagem é tanta que "Mãe Preta” surge, no final do poema, como se oferecesse a si mesma em sacrifício, como mártir. Isto se encontra evidente em: “rasgou, qual pelicano, as maternaes entranhas, / e deu, á Pátria livre, em holocausto, os seios!”265. Mãe-preta, portanto, se sacrifica para a construção da "Pátria livre”: doa - enquanto ama-de-leite - em holocausto, seus seios, e rasga suas “entranhas maternaes” para garantir a sobrevivência de seu “filho afetivo". Esse último gesto é metaforizado na figura do pelicano, animal conhecido por lacerar o próprio peito para, por meio de seu sangue, dar vida a seus filhotes semi-mortos. O pelicano é ainda entendido como símbolo de altruísmo, pela maneira com que alimenta suas crias: em uma bolsa que possui abaixo do bico, reserva os alimentos, coletados pelos próprios filhotes; é como se desse a si próprio como alimento para a prole. Em linhas gerais, o pelicano doava seu próprio corpo e sangue para a sobrevivência de seus herdeiros.

\footnotetext{
${ }^{265}$ Esses versos de Cyro Costa também estão inscritos na estátua “Mãe Preta”, feita por Julio Guerra e erigida pela Prefeitura de São Paulo em 1955, no Largo do Paissandu, próximo à Igreja do Rosário.
} 
Nessa medida, “Mãe Preta”, tal qual o pelicano, rasgava “suas maternais entranhas” para alimentar seu "filho branco". Ela, portanto, não se sacrifica pelo filho natural; este, em certa medida, também fora dado em sacrifício. Ela se sacrifica pelo filho branco, que é metaforizado como a "pátria livre".

O sacrifício da “Mãe Preta/Pelicano" pode também ser comparado com aquele dos mártires cristãos, seja na figura de Cristo, ou na de sua mãe Maria. No primeiro caso, "Mãe Preta” se auto-imola pela salvação de seus filhos. Já a simetria com a figura da virgem Maria se faz evidente de outra maneira: tal como a santa, ela se resignara em criar com amor extremo um filho que não era naturalmente seu. Ambas se doavam a essa criação cuidadosa de onde adviria seu sofrimento, seja pela imolação do Cristo, seja pela ingratidão do filho branco. Maria dera seu filho em holocausto para a salvação da humanidade, mãe-preta dera seu próprio filho natural em sacrifício ao abdicar dele para cumprir suas obrigações como ama dos filhos do senhor branco e, por meio dessa “criação de filhos alheios”, ajudou a edificar a pátria livre.

É plausível, nessa representação da "Mãe Preta”, compreendê-la como uma espécie de “santa”, uma vez que sofre nas mãos de seus senhores e senhores mirins, mas os ama com um fervor semelhante àquele com que reza. O martírio que a mãe-preta viveu não lhe causou revolta; ao contrário, a santificou. Como advertira Roger Bastide, no Brasil, “o tema da valorização do homem [e mulher] de cor não toma, realmente, a forma de liderança na luta de classe, mas a de

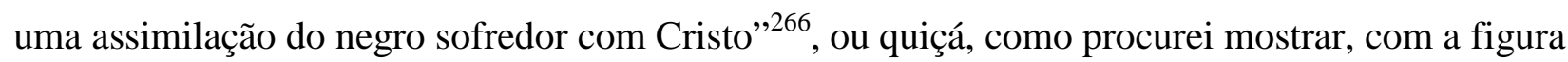
da virgem Maria, mais especificamente, sua versão morena: Nossa Senhora da Conceição Aparecida.

Talvez de descrições como essa - que deixam mais aparente a semelhança entre ela e a Virgem Maria - surgirão interpretações da imagem da mãe-preta conectadas à figura de Nossa Senhora da Conceição Aparecida. Também preta e mãe, sobretudo mãe sacrificada pelo holocausto de seu próprio filho para salvar a humanidade, é a padroeira da pátria livre e mestiça, ou seja, a pátria brasileira. Tal indicativo também aparece nesse poema. Deste modo, como mãepreta - mãe de bondade extrema e santificada - ela cria seus filhos brancos e pretos, tornando-se metáfora da pátria. Da pátria-mãe que acolhe a todos. ${ }^{267}$

\footnotetext{
${ }^{266}$ Roger Bastide. A Poesia Afro-Brasileira. São Paulo, Martins Fontes, 1943. p. 136.

${ }^{267}$ Detenho-me com mais detalhe na comparação entre mãe-preta e Nossa Senhora da Conceição Aparecida na seção “Considerações Finais".
} 
Nessa seção, mãe-preta aparece como "santificada” e “martirizada” pelo sofrimento de sua condição escrava - “escrava do amor” que tem por seus filhos brancos - aproximando-se dos mártires cristãos. Pede perdão ao Senhor, pela crueldade de seu senhor (ato semelhante ao de Cristo), e oferece seu corpo e seu filho natural em holocausto por seus filhos brancos, que significam a pátria (atos miméticos aos de Cristo e da virgem Maria).

Nesta medida, o surgimento dessa pátria livre e mestiça - criada com leite e cuidados de uma mãe-preta - implica na dissolução ou sacrifício do elemento negro pelos brancos. Mas os negros são representados como seres santificados, que se prestam ao sacrifício.

\section{O legado da mãe-preta e da escravidão}

“A escravidão permanecerá por muito tempo como a característica nacional do Brasil. Ela espalhou por nossas vastas solidões uma grande suavidade; seu contacto foi a primeira forma que recebeu a natureza virgem do país, e foi a que ele guardou; ela povoou-o, como se fosse uma religião natural e viva, com seus mitos, suas legendas, seus encantamentos; insuflou-lhe sua alma infantil, suas tristezas sem pesar, suas lágrimas sem amargor, suas alegrias sem causa, sua felicidade sem dia seguinte... Ela é o suspiro indefinível que exalam as noites do Norte. Quanto a mim, absorvi-a no leite preto; ela envolveu-me como carícia muda toda a minha infância. (...) Não só esses escravos não se tinham queixado de sua senhora, como a tinham até o fim abençoado... A gratidão estava ao lado de quem dava. Eles morreram acreditando-se os devedores... seu carinho não teria deixado germinar a mais leve suspeita de que o senhor pudesse ter uma obrigação para com eles que Ihe pertenciam... (...) Esse perdão espontâneo da dívida do senhor pelos escravos figurou-se-me a amnistia para os países que cresceram pela escravidão, o meio de escaparem a um dos piores taliões da História... Oh! os santos pretos! seriam eles os intercessores pela nossa infeliz terra, que regaram com seu sangue, mas abençoaram com seu amor! (...) Raça generosa [a negra] entre todas que a desigualdade de sua condição enternecia em vez de azedar e que por sua doçura no sofrimento emprestava até mesmo à opressão de que era vítima um reflexo de bondade..." 268

Esse trecho, escrito por de Joaquim Nabuco, faz parte do capítulo “Massangana”, que integra suas memórias intituladas, Minha Formação. “Massangana” era o nome do engenho em que o autor passara sua infância. Ele diz que fora aí que tivera seu primeiro contato com a

\footnotetext{
${ }^{268}$ Joaquim Nabuco. “Massangana” in: Minha Formação. Rio de Janeiro, Clássicos Jackson, 1900/1964. p.232, 238 e 239. Grifos meus.
} 
escravidão de maneira desnaturalizada, quando um negro veio pedir, a seus pés, para que sua madrinha o comprasse. Tal cena teria selado o destino de Nabuco, como combatente incondicional da escravidão.

Mas o que importa é que finda a escravidão, quando escrevia as suas memórias, Nabuco passou a experimentar uma "singular nostalgia, que muito espantaria um Garrison ou um John Brown: a saudade do escravo”. ${ }^{269}$ Mas essa saudade é peculiar; não se trata de sentir falta do arbítrio da escravidão, ou de alguma mão-de-obra que realizava seu serviço “de graça”. Nabuco estava saudoso dos escravos, “sempre bondosos, carinhosos" e exemplo da “doçura” e "benevolência”.

Nabuco, como muitos dos literatos que analisei nesse capítulo, escreve num contexto imediatamente posterior à Abolição. É justo nesse momento que se consolidam representações mais alentadas sobre a escravidão brasileira. Tais representações tentam dar conta dessa experiência íntima e duradoura com a instituição escravidão. Elegem, portanto, personagens diletos na construção dessa memória de um passado recente. A mãe-preta é uma dessas figuras e tal qual os escravos mencionados por Nabuco - é descrita como “bondosa”, “dócil”, despertando muita saudade.

Nas fontes analisadas, ela é uma figura “saudosa” pelo carinho com que trata seus brancos “filhos de leite”. Nessa medida, a maternidade da personagem é híbrida; mesclando elementos de natureza (o leite) e de cultura (os cuidados).

Essa mãe-preta qualificada positivamente mantinha, de ordinário, relações muito próximas com a família patriarcal branca; sendo, até mesmo, muito assemelhada moralmente aos seus senhores. Ela era, portanto, uma figura “civilizada”, “quase como os brancos”. Era também, eminentemente "civilizadora”, ao socializar as crianças; por meio do ensino da religião e da narração de histórias. Mas, em função desta semelhança com os brancos, a diferença era trazida à tona. Mãe-preta era, então, realocada em seu status original e inferior - de escrava e preta marcado pela linguagem estereotipada. Logo, em se tratando de mãe-preta, há proximidade e afetividade contundentes entre brancos e negros; contudo, tais sentimentos não conseguem romper com a hierarquia e a diferença.

Dessa maneira, a mãe-preta não implica num escamoteio total da escravidão. A instituição, ao contrário, está sempre presente, ainda que nuançada, qualificada como “mais amena”, ou borrada por vínculos íntimos e afetuosos. Nas fontes é, ainda, essa instituição arbitrária que veta -

${ }^{269}$ Idem. p. 231. 
ou prejudica - a possibilidade de efetivação de uma maternidade natural da escrava: ser mãe-preta de filho preto. Nesse caso, as escravas sequer são descritas como “mãe-pretas”; são apenas “amasde-leite”. Figura ainda mais distante da mãe-preta é a "mãe escrava”. Ela é a própria denúncia da escravidão, tratando-se muito mais de uma “categoria sociológica” - a escrava - do que de uma personagem “pessoalizada”. Mas ainda assim, ela é dotada de “virtude moral”, na medida em que tenta realizar sua função materna.

Desse modo, tanto a mãe-preta, como a “ama-de-leite” e a “mãe escrava” têm características “civilizadas”: uma vocação para serem “mães exemplares”. Mas essa vocação também comporta suas exceções: as "negras feiticeiras”, que matavam seus próprios filhos para libertá-los da escravidão. Essa última representação de negra “mãe escrava” é, dentre todas, a menos civilizada e mais “outra” em relação aos brancos. No entanto, mesmo nela é possível perceber “humanidade”; expressa no propósito com que matara os filhos: para libertá-los do jugo a que estariam submetidos.

Mas retornando às representações da mãe-preta e de seu par, pai-joão, eles surgem, nas fontes, como realizadores de inúmeros “sacrifícios sem pesar” para a criação de seus filhos brancos, ou mesmo, da própria pátria brasileira. Aqui, novamente, as obras dos literatos estudados se aproximam da descrição da figura do escravo feita por Nabuco. Nela, a "suavidade” que o escravo representava eram as “tristezas sem pesar”, as “lágrimas sem amargor”, “as alegrias sem causa”, a "sua felicidade sem dia seguinte”. Ou seja, tal qual nos textos dos literatos, o escravo era sinônimo dessa "bondade extremada": de quem é martirizado pelo trabalho, mas que deixa apenas a alegria como herança. A escravidão fez com que "regassem com seu próprio sangue" a terra brasileira, mas era esse mesmo sangue que trazia o legado de “amor" inigualável. E o abolicionista, assim como muitos dos brancos de minhas fontes, absorveu essa "suavidade" e “bondade” negras por meio do leite de uma escrava.

Esse altruísmo e abnegação da mãe-preta e de pai-joão é visto também como responsável pela fusão de nossa cultura mestiça: “mas essa fusão só foi possível pelo amor franciscano, talvez, mas primeiramente o amor da ama de cor pelo menino branco, e do menino branco pela sua outra mamãe. Um amor bom como o leite materno. O negro não luta, não se endurece em atitudes defensivas, ele se dá, faz a dádiva de si mesmo, e é graças a essa entrega que ele triunfa, que ele invade a cultura branca para adoçá-la, sensualizá-la.”270

\footnotetext{
${ }^{270}$ Roger Bastide. "Doçura do Leite das Negras" in: Letras e Artes - Suplemento literário do jornal A Manhã. Rio de Janeiro, 22/02/1948. p. 5.
} 
É por se "dar em sacrifício", por se "dar a si mesmo em oferenda”, que a ama, em sua relação com o menino branco, teria contribuído, segundo Bastide, para uma interpenetração de culturas. E essa cultura mesclada acaba, no contexto dos anos 1920/1930, por ser reconhecida justamente como uma de nossas peculiaridades nacionais. Mãe-preta e pai-joão, nesse período, ao se doarem para os brancos, se "redimem". Isso porque, passam a ser reconhecidos como uma das influências - no caso, negra - para a constituição de uma pátria mestiça.

Mãe-preta e pai-joão, ao serem incorporados como formadores da cultura nacional, são “expiados” da marca da escravidão. Assim, ainda que essas personagens se "sacrifiquem” pelos brancos e pela pátria, elas se sentem "devedoras”. Nessa medida, o reconhecimento da mãe-preta e de pai-joão como uma influência formadora da infância branca do Brasil, é tido como "dádiva”, como ato de "gentileza branca", que os reconhece enquanto "humanos" e "civilizadores".

Esta gratidão também era tematizada nas memórias de Nabuco; os escravos de sua madrinha tinham os mais "sinceros afetos e uma infinda gratidão" por sua senhora. Desse modo, numa paráfrase de Nabuco: a gratidão estava ao lado dos escravos que se doavam, "numa verdadeira escravidão do amor"; e "eles morreram acreditando-se os devedores, pouco dignos da maneira benemérita com que eram tratados pelas famílias patriarcais mais permissivas”. Sua "santidade não teria deixado germinar a mais leve suspeita de que o senhor pudesse ter uma obrigação de ser bom para com eles, que lhe pertenciam”.

As mães-pretas e pais-joões dessas fontes se sentem devedores e gratos pela "maneira quase familiar" com que eram tratados cotidianamente, e pelo reconhecimento de seu sacrifício como edificadores da pátria mestiça.

Nessas fontes eles significam, portanto, seres "quase brancos", "quase civilizados"; existiram mediante a escravidão, e que deixaram como legado um "amor" e uma "afetividade" inigualáveis. A instituição arbitrária, por meio de mãe-preta e pai-joão, edificara um legado de "bondade”, “amor”, "histórias folclóricas” e “doação”. Mãe-preta e pai-joão na obra destes literatos permitem, portanto, consolidar uma memória da escravidão que não se limita à violência.

As palavras de Nabuco são, novamente, esclarecedoras a respeito dessa memória dos literatos "brancos" sobre a escravidão. Era a "bondade do escravo martirizado", que levava ao "perdão espontâneo da dívida do senhor pelos escravos"; que dava "alento" e "esperanças" a Nabuco, e à elite branca, culpados por terem crescido com a escravidão. Essa vocação para o perdão é, em verdade, "a santidade do escravo" - e da mãe-preta - que se sacrifica por seus senhores. 


\section{CAPÍtULO 4}

\section{Diversos sentidos da mãe-preta na literatura infantil brasileira}

\section{Introdução}

Os anos de 1930 podem ser reconhecidos como o período em que a literatura infantil consolidava-se no Brasil como gênero literário. O Sítio do Picapau Amarelo, de Monteiro Lobato, é a obra tomada pelos críticos como fundadora desse estilo.

É importante observar que em torno dessa literatura, cujo público-alvo eram as crianças, aglutinam-se obras que têm a mãe-preta e as "negras velhas” como personagens diletas. No ano de 1932, são publicadas As Férias com a vovó ${ }^{271}$, Contos da Mãe Preta - adaptados à leitura das crianças $^{272}$ e Pindorama - leitura pra os cursos primário e ginasial $^{273}$. Em 1936, vem a público Histórias da Velha Totonia ${ }^{274}$ e no ano seguinte: Cazuza $^{275}$ e Histórias de Tia Nastácia ${ }^{276}$. Essa seqüência de títulos será de certa maneira encerrada em 1940, com a publicação de O Boi Aruá $^{277}$.

Desse modo, é possível dizer que a mãe-preta, ou melhor, a figura das "negras velhas” contadoras de histórias, estão presentes num momento de consolidação da literatura infantil brasileira.

A afirmação desse gênero literário para crianças transcorreu paralelamente ao modernismo - movimento que tratou de elevar nossa formação social mestiça, dotada de contribuições das culturas indígena, africana e européia. Esse elogio à mistura cultural e racial também está presente no novo modelo de nacionalidade inaugurado pelo governo Vargas, principalmente em meados de 1930. Considerando este cenário paralelo, cabe ponderar em que medida a mãe-preta - retratada na literatura infantil - estaria envolvida com o processo de enaltecimento oficial da mestiçagem e da cultura popular no país.

A questão torna-se ainda mais complexa, na medida em que a literatura infantil é reconhecidamente uma forma eficaz de transmissão de valores. Trata-se assim de uma produção que divulga e produz costumes, modelos e mentalidades para um público pretensamente

\footnotetext{
${ }^{271}$ Maria Alves Velloso. As férias com a Vovó. Rio de Janeiro, Livraria Francisco Alves, 1932.

272 Oswaldo Orico. Contos da Mãe Preta adaptados à leitura das crianças. Série I, vol.1. Bibliotheca Infantil d'O TICO-TICO, Rio de Janeiro, 1932.

273 Ofélia e Narbal Fontes. Pindorama - leitura para os alunos dos cursos primário e ginasial. Rio de Janeiro, Fernades \& Rohe, 1932.

274 José Lins do Rego. Histórias da Velha Totonia. Rio de Janeiro, Livraria José Olympio Editora,1936.

275 Viriato Corrêa. Cazuza. São Paulo, Companhia Editora Nacional, 1937/1979.

${ }^{276}$ Monteiro Lobato. Histórias de Tia Nastácia. São Paulo, Círculo do livro, 1937/s.d.
} 
específico: as crianças. No entanto, as crianças não se separam de um universo adulto, composto (no mínimo) por seus pais, professores e educadores. Ela é portanto um elemento estratégico na idealização de certa nacionalidade.

Assim, nesta parte da dissertação, analiso as mensagens que são veiculadas por meio das representações da mãe-preta e das “negras velhas” nessa literatura, eminentemente, dirigida e didática.

\section{“Negras velhas” contadoras de histórias}

"No Brasil, depressa a velha indígena foi substituída pela velha negra, talvez mais resignada a ver entregue ao seu cuidado a ninhada branca do colonizador. Fazia deitar as crianças aproximandoas do sono com as estórias simples, transformadas pelo seu pavor, aumentadas na admiração dos heróis míticos da terra negra que não mais havia de ver. Dos elementos narrados pelas moças e mães brancas, as negras multiplicavam o material sonoro para a audição infantil. Humilde Sheerazada, conquistava, com a moeda maravilhosa, um canto na reminiscência de todos os brasileiros que ela criava. Raramente vozes européias evocariam as estórias que os tios e tias narravam nas aldeias portuguesas. Os ouvidos brasileiros habituaram-se às entonações doces das mães pretas e sabiam que o mundo resplandecente só abriria suas portas de bronze ao imperativo daquela voz mansa, dizendo o abre-te Sésamo irresistível: era uma vez...”278

Nesta citação, encontram-se reunidos boa parte dos elementos que compõem a representação da mãe-preta nas obras de literatura e literatura infantil. Negra sempre “envelhecida”, "bondosa”, "resignada”, que cuida dos filhos de seu senhor com "extremo cuidado" e "carinho", criando-os como se fossem seus. De vontade fraca diante dos apelos dos pequenos, contava histórias irresistíveis de princesas, de bichos, de medo e etc. Era nos serões, após o jantar, que essa voz relembrada em minúcias - “sonora”, de entonações “doces”, “mansa” - ninava as crianças rumo a um sono de maravilhamento equivalente ao de suas histórias.

Essas histórias contadas pela narradora, em meados das décadas de 1920/1930, são associadas ao folclore, a uma sabedoria "típica da terra” e a uma cultura nacional em formação. A “negra velha contadora de histórias” surge, então, reincidentemente como a narradora destes racontos.

\footnotetext{
${ }^{277}$ Luís Jardim. O Boi Aruá. Rio de Janeiro, Livraria José Olympio Editora, 1940/1970.

${ }^{278}$ Câmara Cascudo apud Leonardo Arroyo. Literatura Infantil brasileira: ensaio de preliminares para sua história e suas fontes. São Paulo, Edições Melhoramentos, 1968. p. 51 e 52. Grifos no original.
} 
A memória das histórias contadas pelas negras velhas é um dos pontos mais comuns nas fontes aqui trabalhadas. Não só a temática das histórias (de medo, bichos e folclore) é lembrada mas, sobretudo, a maneira como eram contadas é digna de nota. São muitos os comentários sobre a "voz" dessas narradoras.

Essas contadoras de histórias eram, em algumas ocasiões, as próprias amas-de-leite das crianças, como nos revelam os depoimentos recolhidos por Monteiro Lobato em O Sacy-Perêrê: Resultado de um inquerito ${ }^{279}$. Nesse livro, o escritor organizou as respostas dadas a uma enquete feita por ele mesmo com os leitores da Revista do Brasil. Tratava-se de um questionário sobre a figura do saci, perguntando sobre as histórias de suas peripécias e quem lhes havia contado tais casos. Nas respostas a esta última pergunta, abundam amas, mucamas e negras velhas. Foi desse material do fabulário nacional que, anos mais tarde, Lobato tirou a idéia de escrever sua primeira obra infantil: O Saci. A seguir alguns desses depoimentos:

"A maior parte da minha infancia passei-a na fazenda de meu pae, para além de Pirajú.

Foi ahi que desde a mais tenra edade soube da lenda do Sacy.

Mas, qual brasileiro que não recebe com o leite materno as superstições e lendas, tão abundantes no Brasil?

Poucos, bem poucos, são os que, no aprender o 'signal da cruz', não sejam instruídos das diabruras do Sacy, das devastações dos Lobishomens e da má fama do Caipora..."280

"Nunca tive medo delle, porque Dindinha (era como eu e meus irmãos chamavamos a velha ama que a todos nós pageara), nunca o considerara um mau diabo e, ao contrario disto, mantinha com elle transacções que lhe eram utilissimas, conseguindo do capetinha serviços inestimaveis por um preço infimo.

Não sei bem como Dindinha conciliava a sua fé catholica e suas relações com o capetinha; rezava o terço, accendia a lamparina do oratorio, fazia promessas aos santos e, todos os dias, dava um ovo ao sacy. Ella nos explicava que os santos vivem no céu e nos servem para depois da morte, ao passo que o capetinha, vivendo na terra, presta os seus serviços aos vivos que o tratarem bem."281

Nesse primeiro depoimento, novamente ${ }^{282}$, é o leite materno que parece transmitir tanto a religião, como todo um fabulário nacional presente nas histórias folclóricas. Resta saber de qual leite "materno" se tratava: se era o próprio leite materno da mãe natural ou, o que era mais comum, leite "materno” da ama negra, figura essa que era mais iniciada nesta fauna folclórica.

\footnotetext{
${ }^{279}$ Monteiro Lobato. O Sacy-Perêrê: Resultado de um inquerito. Gráfica JB S.A., Rio de Janeiro, 1918/1998. Edição fac-similar.

${ }^{280}$ Idem. p. 213.

${ }^{281}$ Idem. p. 223 e 224.

${ }^{282}$ No capítulo anterior trabalhei a noção de “maternidade” que envolvia tanto ligações de leite, quanto cuidados socializadores, tais como a transmissão da religião e a narração de histórias.
} 
No caso do segundo testemunho, não resta dúvidas de que "Dindinha” era uma ama negra; e ela não só conhecia as histórias das reinações do saci como “negociava” com o próprio. Na figura de “Dindinha”, religiosidade e fabulário se misturavam, gerando um catolicismo no mínimo popular, mas também eminentemente mágico.

Há, ainda, algumas outras declarações que revelam a conexão entre o saci (ou personagens do folclore nacional) e as negras remanescentes da escravidão doméstica:

"O Sacy, como m'o pintava sempre Joanna, a mucama que me criou, o 'mardito', como ella o chamava, era (...)."283

"Affirma não haver crianças desconhecedoras do Sacy, cuja tradição Ihes é transmittida pelas amas e crioulinhos."284

"Uma preta que nos serviu de ama dizia-me que o Sacy adorava um pedaço de toucinho bem cozido."285

“Não ha brasileiro que não conheça, de tradição, este estranho personagem. Durante a infancia, nossa convivencia com os criados e para aquelles que nasceram e cresceram no interior, o convivio com as amas, com os velhos pretos ex-escravos e com os caboclos, fizeram com que se nos arraigasse no espirito, ainda em desenvolvimento, nessa edade, a idéa da existencia de fantasmas e duendes, de demonios e capetas, de Sacys e assombrações. Depois crescemos, formamos o espirito, nos civilisamos e ainda nos restam de tudo isto vagas e saudosas lembranças. $(\ldots)^{\prime \prime 286}$

“O Sacy actual, o moleque peralta, é a forma africana do genio indigena. Do lendario tupy, o que mais se assemelha ao Sacy, tal como nos legaram as alusões das nossas adoraveis mucamas, é o corupira." 287

"Outra narrativa ouvi de minha criadinha, uma moça filha de antigos escravos (...)."288

"A bôa 'Tia Rita', uma velha preta que me pageara, dizia com docilidade depois de me ver praticar um 'banzé':

- Oie, nhô Jogi, minino ansim é qui cigana loca gosta de pápá; sinão o Sacy garra paracê na hora de dromi fazeno um baruião cá sua perna de pau, a fazê micage, a puxá as coberta, e tocá musga, a gritá fino como araponga...

Naquella noite (era infallivel) eu dormia abraçado com minha 'maman', como a chamava, mas noutro dia, poucochinho mais comportado, não deixava de timidamente fazer novas travessuras: a criança 'mesmo um sacyzinho nas peraltagens." 289

\footnotetext{
${ }^{283}$ Monteiro Lobato. Op. cit. 1918/1998. p. 77.

${ }^{284}$ Idem. p. 49.

${ }^{285}$ Idem. p. 129.

${ }^{286}$ Idem. p. 147.

${ }^{287}$ Idem. p. 152.

${ }^{288}$ Idem. p. 160.

${ }^{289}$ Idem. p. 249.
} 
As amas, mucamas, criadinhas, “Tia Rita”, pretos velhos e ex-escravos são as figuras que contavam essas histórias de sacis, fantasmas, duendes, demônios, capetas, ciganas loucas e assombrações. Esses contos também tinham como objetivo amedrontar as crianças, para que não cometessem certas “travessuras”, e tal medo fazia com que recorressem ao regaço da negra para se sentirem protegidas. Uma fala “estereotipada” de escrava, ou de negra africana, aparece outra vez associada às “velhas pretas” que serviam de amas secas para as famílias brancas.

Essas figuras remanescentes da escravidão não são lembradas apenas pelos leitores da Revista do Brasil; elas serão igualmente recuperadas pelos escritores da literatura infantil da década de 1920/30, que compunham seus livros de histórias, quase sempre folclóricas, para as crianças brasileiras.

Tal é o caso de Oswaldo Orico, que se remete a uma "negra velha contadora de histórias" para compor seu livro infantil: Contos da Mãe Preta ${ }^{290}$. A mãe-preta, neste caso, era uma ama. No preâmbulo da obra, o autor tenta explicar didaticamente esta personagem, além de esclarecer como ela inspirou o livro que a traz no título:

\section{“CONTOS DA MÃE PRETA}

Chiquinho, como varias crianças, também teve sua Mãe Preta. Uma criatura simples e boa, que Ihe embalou a imaginação com uma porção de historietas e contos.

Contos e historietas que andam espalhados por esse Brasil a fóra e são deliciosas reminiscencias de nossas velhas amas.

Chiquinho não se esqueceu. Oferecendo aos seus leitores e amiguinhos a BIBLIOTHECA INFANTIL D'O TICO-TICO, lembrou-se de reunir no primeiro volume as narrativas pitorescas que ouviu pela boca da Mãe Preta.

Mãe Preta, a nossa boa Scheherezada... Quando chegava ao terreiro, já de noitinha, enxugando as mãos no avental de chita, a pirralhada exigia, puchando-Ihe a saia;

- 'Conta uma historia, conta uma historia'. E ella, solicita, começava:

- 'Era uma vez'...,291

Nessa introdução, Oswaldo Orico revela que Chiquinho - um dos personagens principais do jornal infantil O Tico Tico - “como várias crianças, também teve sua Mãe Preta”. Assim, a figura da "Mãe Preta” aparece como uma experiência social relativamente disseminada no

\footnotetext{
${ }^{290}$ Oswaldo Orico. Contos da Mãe Preta adaptados à leitura das crianças. Op.cit.

${ }^{291}$ Idem. Folha de rosto s. n.
} 
universo infantil. Além disso, o uso da primeira pessoa do plural - "são deliciosas reminiscencias de nossas velhas amas" - indica que o próprio leitor mirim tivera uma "velha ama” ou, ainda, que estas personagens eram tão comuns que se pareciam com um tipo de "característica brasileira”, compartilhada por todos os filhos da pátria, tal como o sentido expresso em "nossas matas", “nossa natureza”.

No prólogo, “Mãe Preta” é tomada também como sinônimo de “velha ama”, e descrita como ligada às crianças. O autor, nessa medida, remete-se a uma função e locus social próprios da escravidão: a escrava doméstica responsável pela criação dos filhos de seus senhores brancos. Mas a alusão à instituição é feita de modo sutil e indireto.

Desse papel complexo - ama de criação - composto por muitas obrigações, só a narração de histórias e contos é evocada como lembrança, sempre especial: "Ihe embalou a imaginação com uma porção de historietas e contos”. No entanto, as histórias que "Mãe Preta” narra são específicas, tratam-se dos “contos e historietas que andam espalhados por esse Brasil a fóra”. Ou ainda, de "narrativas pitorescas ouvidas pela boca da [personagem]”. Desse modo, as histórias contadas pela "velha ama” não têm autoria, e suas origens são remetidas ao "Brasil afora”; ademais, elas são classificadas pelo autor como "pitorescas”. Assim, é possível dizer que os “contos da Mãe Preta” estão tacitamente associados ao folclore, a esse conhecimento popular.

São justamente essas histórias “tão deliciosas” de sua "Mãe Preta” que Chiquinho alter-ego de Orico - lembrou para contar a seus "leitores” e “amiguinhos” do jornal O Tico Tico. Assim, o autor se remete à “Mãe Preta” como fonte de inspiração das histórias transmitidas em seu livro infantil. Ela é representada, em certa medida, como um repositório de histórias folclóricas.

A personagem é descrita ainda como uma “criatura simples”, “preta”, "velha”, "boa” e “solícita” aos pedidos das crianças. A ênfase na "Mãe Preta” em sua versão de contadora de histórias se faz mais evidente na metáfora "nossa boa Scheherezada...”, e na descrição da figura em atividade no serão, realizado no "terreiro", no começo da noite, quando "a pirralhada exigia, puchando-lhe a saia; - 'Conta uma historia, conta uma historia'. E ella, solicita aos pedidos insistentes,” professava as mágicas palavras “Era uma vez...”

É interessante explorar aqui a associação feita com a personagem árabe Scheherazade. Numa versão mais recorrente, Scheherazade casara-se com um sultão que, por sua vez, havia feito a promessa de casar-se todos os dias com uma nova mulher, assassinando-a pela manhã. Ela, vítima destra situação, encontra uma maneira de ludibriar seu destino: conta-lhe intermináveis histórias, que sempre encontravam seu clímax na manhã seguinte, o que lhe 
permitia viver por mais um dia para terminar a narrativa. Tais histórias eram, portanto, contadas pela narradora, numa situação de pressão, e tinham como efeito, um prolongamento de sua vida. No prólogo, a “Mãe Preta” também narrava suas histórias numa situação de pressão: as crianças seus patrões - “exigiam” os racontos e adormeciam freqüentemente durante o serão, fazendo com que no dia seguinte as histórias continuassem. Talvez, essa "exigência” seja um outro indício de que a escravidão comporia um ambiente de fundo da introdução do livro de Orico.

Neste mesmo contexto modernista, dos idos de 1930, José Lins do Rego também lembra com profundidade e alegria da velha Totonia; contadora de histórias que conhecera na infância. E tamanha era a marca que deixara em sua memória, que seu único livro infantil a traz no título, Histórias da Velha Totonia ${ }^{292}$, e no prólogo. Nessa abertura à obra, ele faz uma dedicatória, na qual justifica os motivos que o levaram a escrever justamente aquelas histórias àqueles meninos, os do Brasil.

\begin{abstract}
“Aos Meninos do Brasil,
Ainda me lembro hoje da velha Totonia, bem velha e bem magra, andando, de engenho a engenho, contando as suas histórias de Trancoso. Não havia menino que não lhe quisesse um bem muito grande, que não esperasse, com o coração batendo de alegria a visita da boa velhinha, de voz tão mansa e de vontade tão fraca aos pedidos dos seus ouvintes.

Todas as velhas Totonias do Brasil se acabaram, se foram. E outras não vieram para o seu logar. Este livro escrevi pensando nellas... Pensando na sua velha Totonia de Sergipe, Sylvio Romero recolheu estas mesmas histórias que eu procuro contar aos meninos do Brasil.

Quizera que todos elles me ouvissem com a ansiedade e o prazer com que eu escutava a velha Totonia do meu engenho.

Se eu tiver conseguido esse milagre, não precisarei de maior alegria para minha vida." 293
\end{abstract}

José Lins do Rego retoma a personagem de “Totonia” como sendo memorável em função de sua faceta de contadora de histórias. A comoção que causava na audiência tem especial relevo nas lembranças do autor: "os meninos lhe queriam um bem muito grande”, “esperavam, com ansiedade e alegria a visita da boa velhinha”. A voz era um ponto forte nessa reminiscência, de modo que surgia sempre adjetivada; neste caso, era “mansa”. A solicitude aos pedidos das crianças, que já aparecera na personagem de Orico, está mais uma vez presente: “de vontade tão fraca aos pedidos dos seus ouvintes”.

A insistência na velhice também é digna de nota: “velha Totonia, bem velha” e "boa velhinha”. Talvez a velhice se associasse à sabedoria: no caso, num vasto conhecimento de

\footnotetext{
292 José Lins do Rego. Histórias da Velha Totonia. Op. cit.

${ }^{293}$ Idem. s/p no original.
} 
histórias. No mais, a personagem é descrita como "bem magra” e “boa”. A bondade, como já se pôde perceber, é traço reincidente e quase obrigatório tanto à mãe-preta como à “negra velha contadora de histórias”.

Mas, diferente do prólogo já trabalhado, nesse caso a personagem não é nomeada como mãe-preta. Ela é apenas “Totonia”. É um nome próprio, individualizante; dando indícios de se tratar de uma memória pessoal que se torna, por meio desse livro, uma memória literária. Nesse sentido, o autor declara ter escrito essa obra de literatura infantil pensando nas "velhas Totonias do Brasil, que se acabaram, se foram”. Nessa passagem, “Totonia” deixa de ser um nome próprio para se tornar sinônimo de “negras velhas contadoras de história” que se acabaram, tudo indica, com o fim da escravidão. Foi dessa narradora marcante e de origem social referida ao universo da instituição escravista que José Lins do Rego tirou a inspiração para seu livro infantil.

Deste modo, em meados dos anos 1930 - quando não há mais “Totonias” -, cabe a ele, um escritor brasileiro, por meio de seu livro, transmitir às crianças brasileiras as histórias de Trancoso que aprendera com a sua "negra velha” em serões saudosos.

As histórias contadas antes por “Totonia” e agora por José Lins do Rego, também são peculiares; são de Trancoso. Este termo passou a significar no Brasil, principalmente no Nordeste, o gênero narrativo das histórias folclóricas de príncipes, princesas e mouras-tortas. No entanto, originalmente “Trancoso” refere-se a Gonçalo Fernandes Trancoso, autor de Contos $e$ Histórias de Proveito e Exemplo, editado em Lisboa em 1575. ${ }^{294}$ “Totonia” contava histórias folclóricas que agora estão na obra infantil do escritor pernambucano.

José Lins do Rego, na mesma abertura do livro, dá ainda mais informações sobre essas histórias de Trancoso às quais se refere: elas haviam sido recolhidas por Silvio Romero. E o intelectual-folclorista também as coletara pensando em sua "velha Totonia”295. Portanto, as quatro histórias - “O Macaco Mágico”, “A Cobra que era uma princeza”, “O Príncipe Pequeno” e “O Sargento Verde” - narradas na obra foram retiradas do livro Contos Populares do Brasil ${ }^{296}$, escrito por Silvio Romero.

\footnotetext{
${ }^{294}$ A esse respeito vide Nelly Novaes Coelho. Panorama Histórico da Literatura Infantil/Juvenil. São Paulo, Edições Quíron, 1985. p. 40 e 41.

${ }^{295}$ Nessa passagem, tem-se a impressão de que “Totonia” é novamente um termo genérico aplicado às contadoras de histórias de Trancoso, que Romero também teria conhecido. Mas a "Totonia" de Romero era igualmente um nome próprio, referido a uma lembrança de sua infância, a memória de sua ama: "ainda hoje existe, nonagenária, no Lagarto, ao lado de minha mãe, essa adorada Antônia, a quem me costumei a chamar também de mãe. É um dos meus ídolos, dos mais recatados e queridos. Nunca vi criatura tão meiga rezar tanto (...)”. Silvio Romero apud João do Rio. O Momento Literário. Rio de Janeiro, Fundação Biblioteca Nacional, 1907/1994. p. 40 - 42.

${ }^{296}$ Silvio Romero. Contos Populares do Brasil. Belo Horizonte, Editora Itatiaia, 1885/1995.
} 
Estas narrativas são apresentadas em seqüência. Contudo, na obra infantil de José Lins do Rego, a estrutura de serão não é retomada na redação das histórias. Totonia não aparece sentada em roda na varanda, na "boca da noite", contando as histórias "aos ansiosos meninos do engenho". O que se tem aqui é uma estrutura semelhante às dos livros de contos de fadas, em que as histórias são narradas por um sujeito inexistente da fórmula "era uma vez" ou, ainda, "havia um reino distante”.

Mas para compreender como eram esses serões (que não foram reproduzidos no livro infantil) nos quais José Lins do Rego conheceu essas histórias (repassadas aos meninos do Brasil dos anos 1930), convém recorrer ao seu romance de estréia - de tom marcadamente autobiográfico -, e a seu livro de memórias. Em Menino de Engenho ${ }^{297}$, o autor relata a chegada da contadora de histórias, da seguinte maneira:

"A velha Totonha de vez em quando batia no engenho. E era um acontecimento para a meninada. Ela vivia de contar histórias de Trancoso. Pequenina e toda engelhada, tão leve que uma ventania poderia carregá-la, andava léguas e léguas a pé, de engenho a engenho, como uma edição viva das Mil e Uma Noites. Que talento ela possuía para contar as suas histórias, com um jeito admirável de falar em nome de todos os personagens! Sem nenhum dente na boca, e com uma voz que dava todos os tons às palavras.

As suas histórias para mim valiam tudo. Ela também sabia escolher o seu auditório. Não gostava de contar para o primo Silvino, porque ele se punha a tagarelar no meio das narrativas. Eu ficava calado, quieto, diante dela. Para este seu ouvinte a velha Totonha não conhecia cansaço. Repetia, contava mais, entrava por uma perna de pinto e saía por uma de pato, sempre com aquele seu sorriso de avó de gravura nos livros de história. E as suas lendas eram suas, ninguém sabia contar como ela. Havia uma nota pessoal nas modulações de sua voz e uma expressão de humanidade nos reis e nas rainhas dos seus contos. O seu Pequeno Polegar era diferente. A sua avó que engordava os meninos para comer era mais cruel que a das histórias que outros contavam.

A velha Totonha era uma grande artista para dramatizar. Ela subia e descia ao sublime sem forçar as situações, como a coisa mais natural desse mundo. Tinha uma memória de prodígio.

(...) O que fazia a velha Totonha mais curiosa era a cor local que ela punha nos seus descritivos. Quando ela queria pintar um reino era como se estivesse falando dum engenho fabuloso. Os rios e as florestas por onde andavam seus personagens se pareciam muito com o Paraíba e a Mata do rolo. O seu Barba-Azul era um senhor de engenho de Pernambuco." 298

\footnotetext{
297 José Lins do Rego. Menino de Engenho. Rio de Janeiro, Livraria José Olympio Editora, 1932/1980.

${ }^{298}$ Idem. p. 49, 50 e 51.
} 
Como se vê, a personagem é tratada agora por um outro apelido, Totonha, outra variante de Antonia. Ela é apresentada como uma contadora de histórias “profissional”, já que vivia disso. Quando chegava nos engenhos, reunia as crianças para a narração e ganhava em seguida uma "gratificação". Mas esse sentido “profissional” poderia também estar relacionado ao domínio perfeito que a "trabalhadora autônoma" do romance tem de seus meios de produção: a memória e a voz. Sua perícia é tanta, que o romancista não cansa de se referir ao seu “admirável talento”, veículo privilegiado de “uma nota pessoal nas modulações de sua voz”. Em suas memórias, essa voz é assim lembrada: “A voz da velha Totonia enchia o quarto, povoava minha imaginação de tantos gestos, de tantas festas de rei, de tantas mouras-tortas perversas. Tinha a velha um poder mágico na voz.(...) Tinha para mim um poder de maravilha tudo o que saía da boca murcha da velha Totonia.”299 E “as cenas dos encontros eram vividas pela velha Totonia com todos os tons de voz.” ou, ainda, “a voz fanhosa repetia as estrofes.”300

A fascinação pela voz da narradora evoca o que há de mais específico nas histórias contadas em serão: sua expressão é oral; sua significação é promovida pelas descontinuidades da voz e pela gesticulação do narrador presente diante da audiência. Faz sentido, então, associar o papel da narradora de serão ao de uma atriz numa leitura dramática; paralelo que o próprio autor reconheceu ao dizer: “a velha Totonha era uma grande artista para dramatizar”.

No serão, a magia da literatura - o mergulho na história e nos personagens - é promovida pela voz. Daí também a razão pela qual a contadora preferia uma audiência vidrada (embora calada) em sua pessoa; para que não se quebrasse a continuidade do embalo narrativo das personagens incorporadas afastava, desse modo, os meninos com mania de perguntar ou “tagarelar”. “Totonha” possuía, então, uma autoridade diante de seu auditório. E tal respeito fora conquistado pelo domínio perfeito da narração de histórias. Os ouvintes que se encaixavam nas suas preferências ganhavam como benefício uma incansável disposição para contar muitas outras histórias, até mesmo repetindo-as, se interessante fosse. Ou seja, a “vontade fraca aos pedidos dos ouvintes”, expressa no prólogo da obra infantil, era restrita a alguns deles.

Nos serões, a relação entre narradora e audiência é descrita de maneira extremamente carinhosa, num tom de saudade, nas palavras de Marisa Lajolo: “repassada de ternura

\footnotetext{
299 José Lins do Rego. Meus Verdes Anos. Rio de Janeiro, Editora Nova Aguilar S.A., 1987. p. 1205.

${ }^{300}$ Idem. p. 1239.
} 
nostálgica”. ${ }^{301}$ O que José Lins do Rego descreve nos três livros em que menciona “Totonia” é a “alegria” e "ansiedade” dos garotos diante da contadora de histórias.

Mas o autor enaltece não só as “técnicas vocais de narração” da velha negra, mas também sua memória para muitas histórias, o que fazia dela novamente uma figura semelhante à narradora das Mil e uma Noites. Ele menciona ainda uma outra “tática” de “Totonha” para envolver a audiência: a inserção da “cor local” nas descrições das histórias de Trancoso.

Essa admiração constante pela negra contadora de histórias pode ser imputada à própria posição de José Lins do Rego no momento da escritura de seus livros, sobretudo esta obra infantil. Nesse instante ele, tal como “Totonia”, é também um contador de histórias, só que em outro registro: o escrito. E o autor - por meio de sua obra para crianças - pretende, igualmente, iniciá-los na “cor local” de seu país, ao narrar-lhes as histórias de Trancoso.

Desta maneira, nessa analogia de posições, José Lins do Rego evoca como mestra inspiradora de sua literatura a melhor contadora de histórias que conhecera na infância: “Totonia”. Não é à toa que, na dedicatória de seu livro infantil, declara: “Quizera que todos elles [meninos do Brasil] me ouvissem com a ansiedade e o prazer com que eu escutava a velha Totonia do meu engenho. Se eu tiver conseguido esse milagre, não precisarei de maior alegria para minha vida”. Seu objetivo maior parece ser o de ganhar de seus leitores infantis a mesma atitude com que ele, como audiência, recepcionou as histórias de “Totonia”.

A personagem de “Totonia” é descrita na obra de José Lins do Rego como “muito sábia”, dotada de “ótima memória”, além de possuir técnicas elaboradas de narração, que emocionam seus ouvintes. Trata-se, portanto, de uma figura que possui um vasto conhecimento, seja pelo repertório das histórias de Trancoso, seja pelas maneiras especiais de narrar. Sob esses dois aspectos, ela seria tão “civilizada” que o autor a evoca como musa inspiradora. Não só do conteúdo de sua obra infantil como também, em certo aspecto, de sua forma literária.

Viriato Correia, em seu livro infantil Cazuza ${ }^{302}$ - publicado igualmente na década de 1930 -, fala de uma negra velha contadora de histórias. Trata-se de "Vovó Candinha”, lembrada pelo narrador homônimo ao título do livro. Cazuza é um adulto que se lembra das diversas fases de sua infância, e dentre essas recordações está a melhor contadora de histórias que já conheceu:

"A Contadeira de Histórias

\footnotetext{
301 Marisa Lajolo. “A figura do negro em Monteiro Lobato”. In: Presença Pedagógica. São Paulo, Editora Dimensão, 1998. v.4 n. 23 set/out. p. 25.

${ }^{302}$ Viriato Corrêa. Cazuza. Op. cit.
} 
recordação.

Vovó Candinha é outra figura que nunca se apagou de minha

Não havia, realmente, mulher que tivesse maior prestígio para as crianças de minha idade. Para nós, era um ser à parte, quase sobrenatural, que se não confundia com as outras criaturas. É que ninguém no mundo contava melhor histórias de fadas do que ela.

Devia ter seus setenta anos: rija, gorda, preta, bem preta e a cabeça branca como algodão em pasta.

Morava distante. Vinha ao povoado, de quando em quando, visitar a Luzia, sua filha caçula, casada com o Lourenço Sapateiro.

E quando corria a notícia de que ela ia chegar, a meninada se assanhava como se ficasse à espera de uma festa. Não saíamos da porta da Luzia, perguntando insistentemente:

- Quando ela chega?

- Traz muitas histórias bonitas?

- Traz muitas novas?"”303

A contadora de histórias é descrita como sendo "bem preta”, “gorda”, "rija” e com os cabelos brancos “como algodão”. Novamente a velhice faz parte da caracterização da narradora. “Vovó Candinha”, tal como a “Totonia” de José Lins do Rego, não morava na região; vinha de longe, com suas histórias, para visitar a filha Luzia, e divertir a criançada da vizinhança. Pelos elementos expostos na narrativa, é de se supor que fosse de origem humilde, uma vez que sua filha era casada com um sapateiro.

A alegria da criançada era tanta quando corriam os boatos de que "Vovó Candinha" chegaria, que elas logo montavam guarda para recepcionar a narradora. A negra chegava sempre pela manhã, e seu “público cativo” - já à espera - abraçava-lhe com tanta afoiteza, que quase lhe rasgava as roupas. Imaginavam que quanto mais calorosa fosse a recepção, maiores as chances de conseguirem algumas histórias adiantadas... Mas a negra “contadeira” se recusava, alegando:

“- Quem conta histórias de dia, dizia, negando-se, cria rabo como macaco.

Mal a noite começava a cair, a meninada caminhava para a casa da Luzia, como se dirigisse para um teatro. Após o jantar, vovó Candinha vinha então sentar-se ao batente da porta que dava para o terreiro.

Enquanto se esperavam os retardatários, ela fumava pachorrentamente o seu cachimbo.

Sentávamo-nos em derredor, caladinhos, de ouvido atento, como não fora tão atento o nosso ouvido na escola."

Nesse trecho fica evidenciada a “estrutura ritual” do serão: as histórias só podem ser contadas à noite. A contadora, acompanhada de seu cachimbo, senta-se no batente da porta. A audiência mirim cerca a negra e aguarda atentamente, com os olhos acesos e ouvidos atentos ao início da narrativa.

“Ela começava:

${ }^{303}$ Idem. p. $24-26$. 
- Era uma vez uma princesa muito orgulhosa, que fez grande mácriação à fada sua madrinha...

Acendiam-se os nossos olhos, batiam emocionados os nossos corações...

Não sei se é impressão de meninice, mas a verdade é que até hoje, não encontrei ninguém que tivesse mais jeito para contar histórias infantis.

$\mathrm{Na}$ sua boca, as coisas simples e as coisas insignificantes tomavam um tom de grandeza que nos arrebatava; tudo era surpresa e maravilha que nos entrava de um jacto na compreensão e no entusiasmo.

E não sei onde ela ia buscar tanta coisa bonita. Ora eram princesas formosas, aprisionadas em palácios de coral, erguidos no fundo do oceano ou das florestas; ora reis apaixonados que abandonavam o trono para procurar pelo mundo a mulher amada, que as fadas invejosas tinham transformado em coruja ou rã.

Não perdíamos uma só das suas palavras, um só dos seus gestos.

Ela ia contando, contando... Os nossos olhinhos nem piscavam...(...)

Lá pelas tantas, um de nós encostava a cabeça no companheiro mais próximo e fechava os olhos cansados. Depois outro; depois outro.

E quando vovó Candinha acabava a história, todos nós dormíamos uns encostados aos outros, a sonhar com os palácios do fundo do mar, com as fadas e as princesas maravilhosas."

As histórias que ela narrava eram aquelas de fundo folclórico: falavam de "princesas” e "reis” e de "fadas invejosas”, que faziam feitiços para transformar pessoas em bichos. Porém, mais notável do que as novas histórias, era a maneira como eram narradas: o "simples” e o “insignificante” ganhavam um "tom de grandeza”, que arrebatava as crianças, e fazia com que os contos fossem ainda mais compreensíveis para os pequenos. A emoção na narração, as belas histórias, a atenção da audiência... tudo contribuía para que as crianças nem piscassem os olhos durante o serão. Aos poucos, todos adormeciam, uns sobre os outros, sonhando com partes e elementos das histórias contadas. A negra contadora de histórias acalantava coletivamente as crianças durante sua narrativa; por meio desses racontos fantásticos, os pequenos adentravam o igualmente fantástico mundo dos sonhos.

Portanto, em linhas gerais, "Vovó Candinha” é descrita como uma exímia contadora de histórias folclóricas que impressionava a audiência por sua “vocação para narração” e por seu repertório. Trata-se, novamente, de uma velha negra "sábia”, que possuía um papel socializador, por meio da narração destes contos.

A imagem da "negra velha contadora de histórias de Trancoso" também está presente no livro de estréia de Luís Jardim, O Boi Aruá ${ }^{304}$. Escrita durante a década de 1930, a obra só foi publicada em 1940, contendo três histórias: “O Boi Aruá”, “História das Maracanãs” e "História

\footnotetext{
${ }^{304}$ Luís Jardim. O Boi Aruá. Op. cit.
} 
do Bacurau". Todas essas narrativas são contadas por "Sá Dondom”, uma preta velha. Os meninos exaustos de brincar de boca-de-fogão decidem-se por outro programa, menos cansativo e ainda mais divertido: escutar um belo serão na casa de "Sá Dondom”.

“- Vamos ouvir Sá Dondom contar história? Vamos? Ela é boa que é medonha, contando história de trancoso! abreviado:

E nem esperou resposta, animando a todos com o convite

- Vambora, vambora, pessoal!

Todos foram. Era na cozinha. Fizeram uma roda. Sá Dondom no meio. A esteira não chegava para todos. Juca reclamou que o chão estava frio de arrepiar. Sá Dondom pediu que tivessem modos, se quisessem ouvir. Do contrário ela não contava. la ser uma bem bonita, a do boi aruá.

- Juca perguntou logo:

- Que é boi aruá?

Sá Dondom deu um muxôxo, como se a pergunta fôsse tôla. Mas ele insistiu e ela teve que explicar: no sertão se chamava de boi aruá a um boi rajado, escuro.

A velha preta anunciou que ia contar, batendo com o cachimbo apagado no fogão para que a cinza caísse. Antes deu uma cusparada bem longe, de modo a sair o sarro da boca, e começou assim:

$$
\text { (...) }
$$

- Cabeça de gado?

- Sim menino perguntador! Cabeça de gado não pense que é só cabeça do boi não! É cabeça e corpo e tudo! Quando a gente lá no sertão diz cabeça de gado quer dizer uma rês. E rês também quer dizer um boi, uma vaca, e não tem nada com rei não. Tanto faz dizer cabeça de gado, como uma rês, um boi, uma vaca. E agora faça o favor de não perguntar mais nada, porque senão eu paro e conte quem quiser. Basta de tanta pergunta!

Sá Dondom passou um olhão branco e zangado em cima de Juca, e continuou: $(\ldots)^{\prime 305}$

Como se percebe no trecho, a estrutura do serão é retomada na composição textual do livro de histórias. E novamente sua descrição recupera os mesmos elementos: a noite, a negra contadora de histórias, fumando cachimbo, com as crianças em seu entorno sentadas no chão, durante o desfiar das histórias. As narrativas também já são conhecidas como "de trancoso" ou mesmo "folclóricas".

Tal como a velha “Totonia”, a personagem de "Sá Dondom” não gosta de ser interrompida pelas perguntas da audiência, ralhando com as crianças que as formularam. Também como a narradora de José Lins do Rego, “Sá Dodom” é extremamente respeitada, agindo até mesmo de modo um tanto mal-humorado para com as crianças, sobretudo com Juca, que reclamava.

\footnotetext{
${ }^{305}$ Idem. p. 7 e 8.
} 
Nesse serão, qualquer fato que desagrade a velha é motivo de chantagem com as crianças. "Sá Dondom” diante dos descontentamentos, imediatamente ameaça parar de contar as desejadas histórias; caso não seja obedecida.

“Sá Dondom disse que só contava uma. Já tinha contado duas naquela noite, e o resto ficava para o dia seguinte. Também já não eram mais horas de menino estar acordado! Quem dormia muito tarde, já se sabia como era: no dia seguinte coberta estendida para secar!

Mas Juca, que nunca se contentava com as coisas, foi logo dizendo que não, que depois daquela Sá Dondom tinha que contar outra. E ela, dando um muxôxo, disse assim:

- Ora vejam só! Quem fala! Está ali que não se agüenta mais, de olho miúdo que nem formiga e abrindo a boca que nem gato! Mesmo assim a pedir mais. Pois eu só conto essa por muito favor! E se não quiserem, eu chego no fim da história, digo que entrou pela canela de pinto, saiu por uma de pato, e quem quiser que conte quatro! Eu é que não conto mais!

Todos os meninos disseram que não fazia mal não. Contasse só uma mesmo. (...)"306

"Sá Dondom” não parece ser tão fraca diante das vontades de seus ouvintes; como era “Totonia”. Sempre faz um arremedo "brabo" diante dos pedidos e, antes de ceder, estabelece suas condições, sempre aceitas pelas crianças, desejosas de mais histórias. Outro ponto de recorrência é o fato das crianças irem adormecendo embaladas pelas narrativas da velha. Ninadas pela voz que modula as diferentes personagens da história.

A contadora de histórias também demonstra pouca paciência, dando seus "muxoxos", diante de perguntas que considera tolas; mas tolice, nesse contexto, significa a ignorância da audiência perante as “coisas do sertão”, ou mesmo, de outros elementos da cultura popular.

"E daí a pouco aquele rolo feio - boi, cavalo e tudo embocou na caatinga adentro que parecia bicho doido do mato.

Aqui Juca franziu o nariz, como se estivesse sentindo mau cheiro. Sá Dondom reparou, dizendo assim:

- Não precisa fungar o nariz não, Juca! Caatinga lá no sertão quer dizer mato. Mato fechado, mato grosso. E nesse mato fechado é que ia aquele rolo medonho, que a gente só ouvia era pau estalando, quebrando-se. (...)"307

Eram, também, consideradas interrupções bobas aquelas em que os meninos discordavam de "Sá Dondom", contradizendo-a nos detalhes que revelavam incoerência diante daquilo que aprenderam na "educação formal”, ensinada na escola ou aprendida com seus pais. Nessa afronta sutil à narradora, é o próprio Juca-perguntador - temendo o silêncio como sanção de que fora

\footnotetext{
${ }^{306}$ Idem. p. 37.

${ }^{307}$ Idem. p. 12.
} 
repetidamente ameaçado - quem ralha com o irmão por conta da interrupção considerada mesquinha:

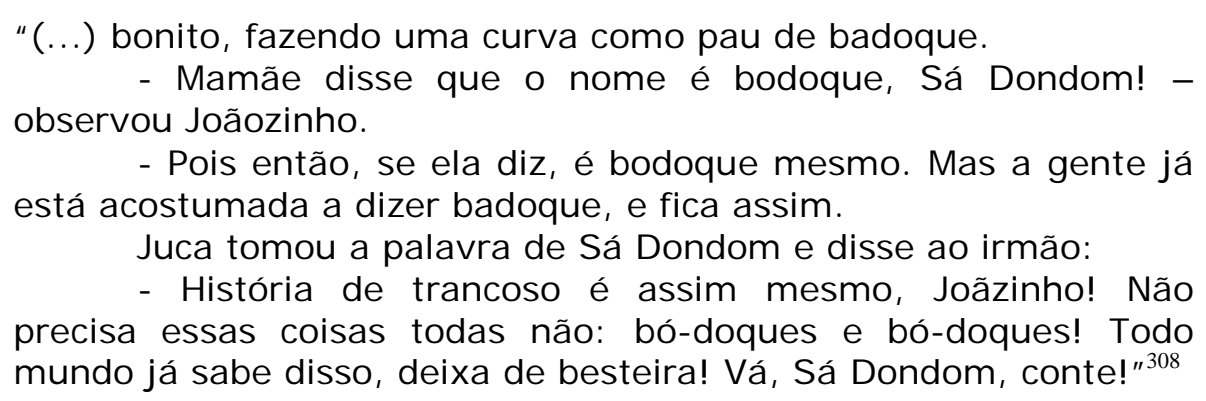

Aqui, percebe-se como a narradora é consciente de que suas histórias apresentam muitos defeitos se julgadas pelo crivo da cultura letrada dos pais dos garotos. Mas ela não se importa com o comentário; construiu uma posição tão firme (uma espécie de "autoritarismo dengoso") e respeitada, que não se abala, não se sente acuada diante da educação formal. Ao contrário, reconhece que certamente a mãe do garoto deveria estar correta. Mas ela é "Sá Dondom”, velha acostumada a contar suas histórias desse jeito - com essas “manias”, “incorreções” e "vícios” - e caso os garotos não gostem dela assim, ela prontamente ameaça parar de contar a história. Os garotos, mesmo com todas as "incoerências”, não se importam: afinal, não há ninguém que conte "histórias de Trancoso" como ela. Assim, a negra velha contadora de histórias possui uma autoridade que advém da sua habilidade como narradora e do conteúdo específico de suas narrativas. É esse conhecimento "popular" e "folclórico" que ela tem para transmitir às crianças, ainda que ele, segundo a norma culta, apresente problemas.

Juca, tal como a narradora, também registra uma consciência das diferentes lógicas que regem as "histórias de Trancoso" e a "cultura polida" de seus pais, ao repreender seu irmão falando: “- História de trancoso é assim mesmo, Joãzinho! Não precisa essas coisas todas não: bó-doques e bó-doques! Todo mundo já sabe disso, deixa de besteira!”. Não só ele e "Sá Dondom” estão cientes dessa diferença de registros, como "todo mundo" já sabe dela. Joãozinho deveria ser "novato", ainda não iniciado nas regras tácitas do serão, onde cultura letrada não é afronta à tradicional e folclórica; são apenas diferentes.

A própria "Sá Dondom" exercita essa espécie de "relativismo" ao narrar seus contos. Reconhece que não sabe termos apropriados para descrever coisas muito refinadas ("eu até nem sei bem o nome delas"), detalhes na vida das camadas ricas da sociedade, ou termos da "alta

\footnotetext{
${ }^{308}$ Idem. p. 11 e 12.
} 
cultura”. No entanto, ainda sem as palavras precisas, ela se faz compreender, usando descrições próprias e expressivas das "histórias de Trancoso":

“Dessa vez então botaram os arreios mais bonitos que ele possuía. Cheio das pedras mais bonitas do mundo. E de todas as cores. Eu até nem sei bem o nome delas. Só sei é que cada uma custou rios de dinheiro, precisando que ele mandasse comprar todas nas terras dos reis e príncipes." 309

A narradora - personagem identificada a essa "cultura popular" - se atém, em suas descrições, aos aspectos sensíveis das coisas (todas as cores) e fala num tom sempre alusivo (“mais bonitas do mundo”, “custou rios de dinheiro”, vinda das “terras dos reis e príncipes”), o que acaba por ajudar a produzir o caráter mágico de suas histórias.

Em certo sentido, o maravilhamento que as crianças sentiam com suas histórias e com sua presença, tão apreciados pela audiência, vêm justamente dessa “imprecisão” própria às "histórias de Trancoso”. Se “Sá Dondom” dissesse que os arreios “mais bonitos do mundo” eram repletos de quartzos, esmeraldas, ônix, ágatas e âmbares, todo o encantamento se desfaria. É como se a magia se localizasse justamente naquilo em que faltam palavras para explicar.

Quando ia começar outra noite de narrações, a regra tácita do serão já era consenso entre a audiência: não deveriam interromper “Sá Dondom” com aquelas perguntas “tolas” (de desconhecimento das coisas do sertão), e tampouco com “correções” às histórias de Trancoso. Tal consciência do regulamento está presente nesta passagem:

“Todos já sabiam: não se podia perguntar nada. Quando quisessem saber qualquer coisa, perguntassem ao pai, que sabia muito, ou então perguntassem ao professor, que ainda devia saber mais. De uma coisa todos sabiam que Sá Dondom não gostava: era que interrompessem a história para 'perguntar besteiras'." ${ }^{310}$

Novamente, reafirma-se a consciência de “Sá Dondom” acerca da sabedoria que vem dos livros, e que é dominada pelos pais e professores. Mas perguntas normalmente direcionadas a essas “pessoas letradas” são, nesse contexto, consideradas "besteiras”. Não são perguntas apropriadas a ela. Afinal, a "negra velha” realiza uma atividade em que esse registro da cultura letrada não tem muito valor e que, além do mais, ela não domina. A narradora admira o conhecimento dos termos populares em que se expressa pois, ao menos, as crianças não a interromperiam com perguntas tolas.

\footnotetext{
${ }^{309}$ Idem. p. 19.

${ }^{310}$ Idem. p. 61.
} 
Em O Boi Aruá, novamente temos a figura da "negra velha contadora de histórias” no serão. Nesse caso, ela aparece como sendo um tanto severa e seca para com as crianças (sobretudo se comparada à “Totonia” ou à "Mãe Preta” de Oswaldo Orico). Freqüentemente reclama, repreende a audiência, solta expressões de descontentamento e ameaça a audiência com seu silêncio. Os pequenos acatam todas as exigências de “Sá Dondom”, uma vez que “ela é boa que é medonha, contando história de trancoso!"311 Assim, a personagem de “Sá Dondom” é absolutamente sábia no repertório das “coisas do sertão”, das "histórias de Trancoso” e de “técnicas narrativas” que causam “maravilhamento”. E é a partir desse conhecimento específico que ela construiu sua posição de autoridade “socializadora” das crianças. Contudo, a "negra velha” é ingênua, e quiçá “ignorante”, se julgada pelo crivo da cultura letrada, na qual ela não é iniciada.

Nesse sentido o autor, nessa sua obra infantil, aposta no "regional”, na "tradição" e no “encantamento” como saberes importantes a serem transmitidos às crianças de todo o Brasil. E a “negra velha” é a narradora dileta para iniciar os infantes nesse conhecimento específico. ${ }^{312}$

As "negras velhas” contadoras de história analisadas, nessa parte do trabalho, são recorrentemente descritas como maravilhosas contadoras de histórias, sabendo modular a voz e encantar sua audiência mirim. A narração desses racontos, em tais livros infantis, é sempre apresentada como um ritual que se efetiva sob a forma do serão: pela noite, a negra sentada ao centro - às vezes acompanhada de seu cachimbo - e as crianças a seu redor. Em geral, nestas obras infantis, as narradoras não gostam de ser interrompidas, mas sempre negociam essas pequenas pausas com as crianças.

As histórias contadas por essas "negras velhas” são as de “Trancoso”, de bichos, de princesas, de medo etc. Todas elas podem ser classificadas, contudo, na categoria de "histórias folclóricas”. Desse modo, os autores de literatura infantil desse período tão preocupado com a consolidação de uma cultura nacional, elegem as histórias folclóricas como sendo as mais adequadas para iniciar as crianças brasileiras no universo de sua "cultura mestiça”. E a "negra velha contadora de histórias folclóricas” surge como a narradora e a socializadora dileta das crianças num conhecimento específico: o conhecimento popular. Essas personagens são,

\footnotetext{
${ }^{311}$ Idem. p. 7.

${ }^{312}$ Por sinal, a comissão julgadora do Concurso Nacional de Literatura Infantil pareceu estar de pleno acordo com os valores selecionados para serem transmitidos às crianças, de modo que esse livro foi agraciado com o primeiro prêmio.
} 
portanto, muito sábias; mas trata-se de uma sabedoria peculiar: das técnicas narrativas do serão, de um vasto repertório de contos e das coisas típicas da terra.

Por mais paradoxal que pareça, a negra velha “civiliza” as crianças na medida em que ela lhes ensina os elementos constituidores de uma parcela da "identidade nacional”. Porém, ela é “ignorante” da outra faceta dessa civilização nacional: a “alta cultura” ou "norma culta”.

Essas “negras velhas” não são mais necessariamente descritas como amas-de-leite, mucamas, criolinhas. Apenas a "Mãe Preta”, do livro de Oswaldo Orico, era apresentada como “ama”. Diferentemente, “Totonia” é uma contadora de histórias “profissional”, que andava de engenho em engenho recebendo pequenas gratificações para narrar inesquecíveis contos. "Sá Dondom”, por sua vez, era uma moradora da vizinhança, cuja fama de exímia contadora de histórias era conhecida pelas crianças do bairro que se “empoleiravam” em sua casa para escutála. E “Vovó Candinha” - mãe de uma moradora remediada do bairro - atraía a atenção das crianças da região também por sua fantástica habilidade como narradora de histórias.

Mas nesse mesmo contexto, nos anos de 1930, há na literatura infantil brasileira uma outra espécie de "negra velha” que conta histórias. Trata-se da figura da negra velha “cozinheira e agregada da família branca”.

\section{“Negra velha” cozinheira e agregada da família}

No livro Pindorama ${ }^{313}$, de Ofélia e Narbal Fontes, o narrador, o menino Iberê, mora com sua família, composta pelos pais, a irmã mais nova, Iára e a mais velha, Dail. Mas junto com eles, vivem Quitéria, a cozinheira, e sua filha Isabel. Quitéria é “baiana” e conta aos meninos sobre as festas e comidas típicas de sua terra:

\section{“Reisado}

(...)

Foi quando Quitéria apareceu. Quitéria é mãe da Comadre. É baiana e quituteira como ela só. Sabe fazer manauê de milho verde, mal-casado, arroz de côco, beijú, mãe-benta, manjar-do-céu e tanta coisa gostosa, que nem sei! Usa colares de missangas, pulseiras e braceletes de todas as côres, argolas de prata nas orelhas, sandálias ringideiras e chale de pano da Costa. Enfim, é baiana até ali!

- Na Baía tambem se faz presepe? Perguntei-lhe.

- Ih! Nem fale, Ioiô! Lá é que se faz presepe bonito e ha cada festança de deixar a gente de agua na boca. Não é como aqui: uma festa sem graça, pirão sem sal. Se vosmicê fôsse lá é que havia de gostar.

No meu tempo, não sei se ainda hoje, havia presepes em toda a parte, bailes pastoris, côcos, cheganças, bumba-meu-boi...

- Bumba-meu-boi? Que é isso?

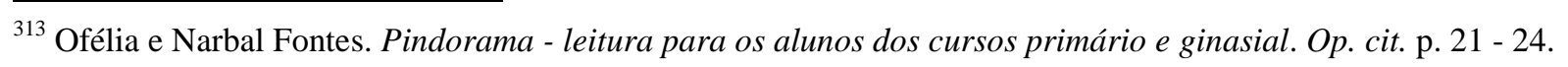


- O'xentes, então vosmicê nunca ouviu falar no bumba-meu-boi? Pois eu Ihe conto.

- Então conte!

- Na minha terra, quando chega a véspera de Reis, ha um reboliço nas ruas: uma porção de ranchos, com archotes acesos, pandeiros, violões e castanholas. É o dia da visita aos presepes. As casas estão fechadas. Os donos fingem que não esperam ninguém. As moças brancas, mulatas e crioulas, vestidas de pastorinhas, chegam e cantam(...)

Então, abrem a porta. O rancho entra, dança, canta e toca lá dentro, ao pé do presepe.

A chegança é feita num palanque armado na praça. Aparecem dois navios, com almirantes, marinheiros e tudo. Um é cristão, outro é pagão. Os dois brigam e o cristão sai vencedor. Ha muita alegria, tocam pandeiros e canzás, canta tudo em côro e o povo que assiste acompanha.

E o bumba-meu-boi? É o mais engraçado! Aparece um homem com cabeça de boi, acompanhado pelo vaqueiro chamado Mateus, que principia cantando(...)E faz-se a roda e o boi começa a dançar e a investir a torto e a direito.

Quando a Quitéria acabou de contar, Iára estava embevecida. Ela também queria ver o boi dançar.

- Bem, I oiô, vou chegando, botar as panelas no fogo.

E lá se foi Quitéria para a cozinha.

Depois Comadre, que sabe cantar todas essas coisas, ficou ensinando lára as cantigas do bumba-meu-boi. (...)"314

“Quitéria” é descrita como uma cozinheira, muito bem caracterizada tal qual o estereótipo da baiana; tanto nas vestimentas (“chale de pano da Costa”), quanto nos apetrechos (“colares de missangas”, “pulseiras” e "braceletes coloridos”, “argolas de prata” e “sandálias ringideiras”). Além disso, ela conhece muitas festas populares como "bumba-meu-boi”, “pastoril”, “cheganças” e etc. São os enredos e as histórias dessas festas, que só “as pessoas do povo” conhecem, que “Quitéria” narra aos filhos dos patrões da casa em que trabalha. Sua filha Isabel, assim como ela, conhece todas essas festas folclóricas, e sabe cantar todas as suas cantigas, de modo que as ensina a Iára, filha da família patronal, e sua amiguinha de mesma idade.

“Quitéria” também é descrita não como uma mera “cozinheira”, mas como uma cozinheira especializada numa “culinária típica”. As especialidades da negra são, principalmente, os doces; de modo que ela é uma "quituteira”, cujo repertório de receitas inclui: "manuê de milho verde”, “mal-casado”, “arroz de côco”, “beiju”, “mãe-benta” e “manjar-do-céu”. Nessa medida, “Quitéria” é associada a uma tradição culinária tida como “popular” ou, ao menos, “baiana”.

O menino, do livro de Ofélia e Narbal Fontes, tinha o nome de Iberê, mas a cozinheira da família refere-se a ele como “ioiô" - diminutivo de "sinhô" - numa alusão a termos específicos

${ }^{314}$ Idem. p. 21 - 24. 
da sociedade escravista, mas que perduraram no trato social para além da Abolição. Já Iára e seus irmãos chamavam Isabel pelo termo “comadre”.

Como já apresentado, na seção em que tratei da "Mãe-preta de filho preto”, “comadre” e “compadre” eram os termos pelos quais os irmãos de leite se tratavam. Na verdade, era o designativo usado pelo filho(a) branco(a) para tratar seu “irmão (irmã)” negro(a). Desse modo, aquele que está numa posição hierárquica superior - os filhos brancos da família patronal - usam um termo de cumplicidade, de parentesco afetivo, para se colocarem mais próximos da filha da cozinheira negra. Usar o termo “comadre” significa, nesse contexto, aproximar-se afetivamente de pessoas em situações sociais inferiores. Aqui há, novamente, "pronomes de tratamento" surgidos na época da escravidão, que se reinventaram e perduraram nos usos em lugares sociais similares: escrava doméstica e empregada doméstica, filho(a) da ama e filho(a) da cozinheira.

Nesse outro trecho do livro, reproduzido a seguir, há mais detalhes sobre a relação de “Quitéria” e “comadre” com a família de seus patrões. Esse capítulo do livro é destinado a explicar para os leitores a “data cívica” do Treze de Maio. Assim, “Isabel” havia sido selecionada na escola para recitar versinhos em homenagem ao "dia ilustre”. "Quitéria”, quando soube da notícia, ficou muito orgulhosa de sua filha. Iára também estava feliz com o fato de sua "comadre" ter sido escolhida, pela professora, para um papel de evidência numa atividade do colégio:

“lára também: mostra-se, mais do que nunca, vaidosa de sua comadre. É um gôsto vê-la quando Isabel recita; esta pode dizer os versos da peor maneira possivel, porque lára não deixa de contemplá-la embevecida! Chega-se à comadre depois, faz-lhes carinhos, abraça-a; Isabel olha de soslaio, meio desconfiada, na atitude de quem foi promovida sem saber por que e recebe a homenagem imprevista. Mamãe diz que ela cresceu de importância, e é mesmo.

Logo que Papai chegou, Iarinha foi buscar a comadre para recitar e começarem as recomendações:

- Olhem como vem sem jeito!

- Fale bem alto, Isabel!

- Bem explicado!

- Tire a mão da boca!

- Não fique olhando toda a vida para o chão!

- Largue o cinto!

- Deixem-se de tantos avisos, disse papai. Póde começar, Isabel.

- Meus senhores...

Que alegria...

- Meus senhores. Que alegria

Trago na alma infantil!...

Quando...

Quando nasci não havia

Mais escravos no Brasil! 
- Muito bem! Muito bem! A quadrinha é muito bonita! Agora, peça a Dail que Ihe explique quem eram os escravos e o que se vai festejar no dia 13, aconselhou Papai." ${ }^{135}$

Nesta passagem, fica clara a razão pela qual Isabel fora escolhida para falar justamente do Treze de Maio: filha de “negra quituteira”, a “comadre” era negra também. E a "lição cívica” que caberia a ela ensinar, no livro do casal Fontes, era o fim da escravidão no Brasil: os autores se utilizam de um artifício narrativo interessante, ao colocar uma negra para falar sobre uma data relacionada à libertação do “povo” negro escravizado. Aliás, a própria “comadre” é “batizada” com o nome da Princesa "redentora dos escravos": Isabel. Essa explicação sobre seu nome e sobre o fim da escravidão é dada por Dail, irmã mais velha de Iberê e Iára, à pequena negra: contar.

“Dail sentou-se na escada com a futura declamadora e se pôs a

- Você já tem ouvido sua mãe falar nos escravos, não é?

Sabe que os pretos faziam todo o serviço dos brancos, trabalhavam nas fazendas e eram comprados por dinheiro, como se faz com os brinquedos e as balas... Pois bem: dêsses pobres escravos, alguns eram bem tratados, mas outros não tinham a mesma sorte e eram sempre castigados, amarrados ao tronco, chicoteados, acorrentados... Mas isso ainda era pouco: o que eles mais sentiam era serem separados dos filhos que não viam nunca mais! Porque muitos senhores vendiam os escravos sem se importarem com os parentes que êles deixavam.

Depois, uns homens bons começaram a ter pena dos escravos e se puseram a trabalhar para Ihes darem liberdade. Custou muito, porque os fazendeiros não queriam ficar sem aqueles criados que trabalhavam de graça. Os outros, porêm, esforçaram-se tanto que, afinal conseguiram o que desejavam.

Naquele tempo, o Brasil era governado por uma princesa muito boa, que tinha o mesmo nome que você - Isabel. Se ela não fosse assim boa, os escravos teriam continuado naquela vida tão triste! Porque princesa manda em tudo.

Foi no dia 13 de Maio que a escravidão acabou. Por isso, todos os anos nêsse mesmo dia, ha festa na escola.

Você reparou no que diz o verso? Que você está contente porque não havia mais escravos no Brasil, quando nasceu... É que faz bastante tempo que sucedeu isso. E não pense que é só você que fica alegre! Todo mundo! Todos os brasileiros! E sua mãe, então, nem se fala!

Ela era menina, naquele tempo, e viu tanta gente sofrer! Hoje, é quem poderá dizer a você quanto melhorou a sorte dos pretos. Agora, trabalha onde quer, recebe dinheiro pelo seu trabalho, da mesma fórma que as pessoas brancas; sabe que ninguem vai vender você e vive sossegada.

Você é pretinha, mas é tão querida como se fôsse branca, pois o que vale é ser boa. Tanto assim que lára quer bem a você como irmazinha, não é?

Aprenda bem a poesia para fazer bonito na escola! Já sabe o que ela quer dizer e pode recitar entusiasmada!"316

\footnotetext{
${ }^{315}$ Idem. p. 116 - 119.

${ }^{316}$ Idem.
} 
Nesta passagem, percebe-se que "Quitéria”, além de negra, era velha, uma vez que era “menina no tempo da escravidão”. Assim, é possível ter mais detalhes sobre a origem daqueles “conhecimentos típicos” (tanto das festas folclóricas, como da culinária) do povo; tratava-se de um povo específico, composto por personagens remanescentes da escravidão, tal como a "negra velha Quitéria”.

Este regime violento, segundo Dail, acabou "há bastante muito tempo...” E desde então, a “sorte” de negras como a cozinheira melhorou muito: se antes "eram compradas” e "faziam todo o serviço" sem salário, agora "trabalham onde querem” e recebem salário por isso, tal como os brancos. Mas mesmo durante a escravidão, havia nuanças no tratamento dispensado aos cativos; segundo a menina, "alguns eram bem tratados”, outros eram muito castigados, "amarrados ao tronco", “chicoteados” e “acorrentados”. Ainda assim, este sofrimento era ainda pequeno diante do maior de todos eles: a separação das escravas de seus filhos.

Desse modo, a cozinheira era “a prova viva” da melhoria das condições de vida dos negros no Brasil: não vê mais sua gente sofrer, escolheu onde queria trabalhar, é remunerada por seu serviço e, o principal, não se preocupa com a possibilidade de venda de Isabel. "Quitéria” é, portanto, uma assalariada e agregada da família patronal, e lá vive com sua filha. Além do mais, como recompensa por tantos anos de serviço e dedicação à família empregadora, sua filha freqüenta a mesma escola que a filha dos patrões.

Os "brancos” são, nessa medida, apresentados como bons e permissivos patrões. Essa "bondade dos brancos para com os negros” também está presente na explicação da abolição, feita por Dail. Foram os “homens bons” e a "princesa boa” que “deram” aos cativos - por piedade - a “dádiva da liberdade”, pela qual deveriam ser eternamente gratos.

Na história narrada no livrinho, dessa convivência cotidiana entre as meninas surge uma grande amizade, inclusive um "compadrio”. Mais do que isso, estabelece-se um sentimento verdadeiramente fraterno, salvaguardadas as diferenças de status entre ambas, expressas pela menção à cor. Como já se salientou, o compadrio é uma relação que, por meio do afeto, pretende tornar o "diferente” em "igual”; a filha da empregada e ex-escrava transforma-se, portanto, em “irmã da patroinha”. É isso que fica expresso na passagem: "você é pretinha, mas é tão querida como se fôsse branca, pois o que vale é ser boa. Tanto assim que Iára quer bem a você como irmazinha (...)".

Novamente, há um branqueamento promovido pelo afeto, tornando o agregado cada vez mais branco, “como se fosse da família”. Mas o limite ainda é o "como se fosse”, pois na 
realidade, Isabel permanece negra e filha da ex-escrava “Quitéria”. A explicação revela, enfim, uma suposta bondade e uma "liberalidade” dessa família branca, que trata "tão bem” e "sem preconceitos” suas empregadas negras, querendo-as tão bem - “como se fossem brancas”.

Essa passagem dá margem para pensar um pouco as maneiras como o racismo se efetiva no Brasil. Não se evita a convivência e nem mesmo uma impossibilidade de profundas relações afetivas, mas a diferença - a cor - sempre é retomada como estigma que determina uma hierarquia. Isabel é, nessa medida, “comadre” e "pretinha”, querida como se fosse da família branca. Tal afetividade estaria expressa tanto no termo de “parentesco sociológico” como no diminutivo "inha”, que significa também “quase branca”. Mas no mesmo instante em que a reconhecem como "quase branca”, marca-se a sua diferença presente no termo "preta”.

Em outro livro infantil, As Férias com a Vovó $^{317}$, também publicado na década de 1930, há outra personagem negra, quituteira e agregada da família. Trata-se de “Tia Jovita”, que trabalhava na casa de Dona Clemência, a avó de Marcelo, Zoé, Stella, Tiz e etc. Toda a criançada ia passar as férias com sua vovó e com “Tia Jovita”. A “negra velha” é apresentada como famosa por seus doces e, principalmente, por sua goiabada.

Por vezes descrita como preta, por vezes como mulata; tais tonalidades de cor não parecem importar já que a personagem é, acima de tudo, “velha”. De pano na cabeça, “Jovita” se dedica a fazer doces caseiros que são muito cobiçados pelos netos de Dona Clemência. E para conquistar qualquer raspinha do confeito, os pequenos se oferecem, de modo aparentemente despretensioso, para ajudar a negra.

Ela está sempre resmungando, e é um tanto braba com as crianças. Os netos mais velhos de Dona Clemência se divertem com a situação; já conhecendo “Tia Jovita”, sabem que ela vai aceitar a ajuda oferecida e que todos, felizes, lamberão as fôrmas. Mas a negra velha se faz de durona, e os pequenos respeitam a fachada seca e um pouco rude da negra. Tentando despistar aqueles que insistiam em ajudá-la, “Jovita” fala:

“(...) J ovita - É hora do almoço, hein! Sinházinha já está na sala. Vá tudo se lavar ali no tanque, vá!

Tiz - Você inda quer que a gente ajude depois do almoço, quer? Jovita - Eh! Eh! Depois do almoço, eu quero mais é socego para mexer meu doce.

Stella - Olhe, você querendo eu sei mexer muito bem. Não queimo, não! gente! ${ }^{\prime 318}$

Jovita - Deus me livre! O’ crianças! Sinházinha está chamando,

\footnotetext{
${ }^{317}$ Maria Alves Velloso. As férias com a Vovó. Op. cit.

${ }^{318}$ Idem. p. $141-146$.
} 
Na passagem, nota-se que "tia Jovita” chama sua patroa, D. Clemência, por “sinhazinha”, numa outra referência a termos de tratamento legados pela escravidão.

Depois do almoço, as crianças descobririam a razão do mau humor de "Jovita” ao fazer os doces. Terminando a goiabada, a negra ficava feliz e mais suscetível aos pedidos das crianças. Os pequenos gostavam de ouvir a velha falar, e aproveitavam essa oportunidade para escutar as histórias de “tia Jovita”. Nesse dia, ela contou uma que falava sobre feitiço e magia; fenômenos que influenciavam inclusive no ponto do doce. Daí, seu zelo rabugento na hora do fabrico da goiabada. O feitiço andava no ar, podendo cair no doce, caso a cozinheira conversasse muito ou ficasse desatenta.

Particularmente impactante é momento em que a velha conta um causo que se passara quando ela era pequena, nos tempos da escravidão. Uma negrinha fora enfeitiçada e perdera para sempre o ponto do doce sendo, então, maltratada pelos patrões:

“(...) Os pequenos agarraram as forminhas sentaram-se no chão e regalaram-se de goiabada quente! Que delicia! Jovita sentou-se tambem e fez companhia às crianças. Depois da goiabada prompta, a mulata ficava sempre de bom humor. Os pequenos já o tinham percebido, e, como gostavam de ouvir falar a velha, aproveitavam sempre essa occasião.

O' Jovita, disse Stella; é verdade que o doce desanda quando a gente conversa emquanto está mexendo?

Jovita - É, sim! Até perigoso.

Tiz - Porque é, hein?

J ovita - Porque, sabe, não é? Anda tanto feitiço pelo ar; e, a gente distrahida, cae o feitiço no doce... e prompto!

Zoé - Ah! então é por isso que você não quer ninguém aqui? enfeitiçada.

Jovita - É; me lembro daquella negrinha que ficou sempre

Ruth - Que negrinha? Como foi, hein?

Jovita - Ah! Isso já foi ha muito tempo! Eu era pequena.

Marcello - Ih! Então foi mesmo ha muito tempo!

Jovita - Pois é! Não havia ninguem como aquella creoulinha p'ra fazer os doces. Era cada bananada gostosa - cada goiabada vermelhinha, sempre no ponto! Um dia a pequena estava mexendo a goiabada, quando passou uma borboleta azul.

Marcello - Como as que têm no matto, não é?

Jovita - Assim mesmo. Pois a pequena ficou doida pela borboleta e começou a falar com o moleque que estava ali perto. 'Ah! Eu quero aquella borboleta! Eu quero! Vae apanha-la para mim, Vicente! Ah! Borboleta, espera um pouco, espera!' E o bicho parece de propósito, só esvoaçava em volta da negrinha. Quando esta quis pega-lo, elle fugiu de vez; mas a pequena não acertou mais o ponto do doce. Não houve meio! Estragou um talho enorme. Aquillo era algum encanto, que andava voando para ella ficar tentada! Eu sei que nunca mais a pretinha acertou os doces. Cada vez era uma tachada desperdiçada, e os senhores brigavam que nem era vida.

Ora, disse Adolpho, você não vê logo que ella deixava passar do ponto o doce e que só por isso queimava?! 
Jovita - Credo, menino! Você não acredita em nada! Pois eu me lembro d'essa pequena; ella chorava que fazia pena, dizia que a borboleta tinha vindo botar quebranto n'ella.

Adolpho não quis brigar com a velha e calou-se; as meninas piscaram um olho e abafaram uma risadinha, mas Vera e Marcello estavam um tanto assombrados.

Vera - o J ovita, ainda ha encantos?

Jovita - Si ha! Si ainda ha feiticeiras!

Onde - disse Vera.

Jovita - Oh! Gente! Não é tão longe assim! Ali mesmo no caminho

do Corrego mora a tia Eva. Dizem que ella é bruxa.

Vera - É?!!!

Stella - Vamos pedir a mamãe para ir ao Corrego?

É, brinquem com ella, p'ra vê só!

A mulata afastou-se resmungando." 319

A negra velha "Jovita", assim como a negrinha que conhecera em sua infância, são especialistas numa "culinária típica”: o fabrico de doces de tacho, entre os quais estavam bananadas, goiabadas e cocadas de abóbora (citadas num outro capítulo do livro). Essas personagens negras e remetidas a um tempo passado - no qual havia "moleques e senhores" relacionado à escravidão, são justamente as iniciadas nesses doces tradicionais. Assim, há novamente uma associação entre um "saber típico", do povo, e as personagens “remanescentes” da instituição escravista. É como se o povo brasileiro fosse composto principalmente por figuras semelhantes a essas negras velhas.

Nesse trecho, "tia Jovita" se revela crente nessas "superstições populares de feitiços e bruxas”, mas torna-se motivo de chacota das crianças mais velhas, que não discutem com ela, mas soltam risinhos abafados. "Jovita" representa, nessa medida, o povo brasileiro incauto, permeado por crendices; isso visto da perspectiva "científica" dos "letrados", que no caso eram os netos mais velhos de Dona Clemência. A negra, ultrajada com essa "criançada sabida da cidade”, que não acredita mais em nada do que ela lhes diz, se afasta, resmungando.

Desse modo, o povo brasileiro (também composto por descendentes de escravos), no livro de Ofélia e Narbal Fontes, aparece de maneira ambígua: ora é guardião de um saber "especifico" da terra - no caso as histórias e a culinária -, ora é desqualificado como "ingênuo" e "crédulo", diante do "saber formal".

Retornando à história do livro, a brabeza de "tia Jovita" não era sinal de que ela não quisesse bem os netos de sua sinhazinha. Ao contrário, na despedida, a negra velha derrete-se em lágrimas com a partida dos pequenos...

"Capítulo XXIV - Até para o Anno

${ }^{319}$ Idem. 
(...) As meninas de D. Genoveva primeiro. Na vespera da viagem, despediram-se de tudo. Da parreira, do jardim, dos patos e tambem da Anna, da Zelinda e da tia Jovita. Esta enxugou os olhos na ponta do avental e entregou a Verinha umas latas de goiabada.

Para todas, hein?... recommendou ella. E não vão brigar!

Obrigada tia Jovita. Não se esqueça de nós ouviu?!

Não esqueço, não! E vocês vejam lá se aprendem tanta cousa para não escrever às velhas!

Nós havemos de escrever, sim, prometteu Stella.

[...] Lá pelo meio dia, como sempre, chegou o correio. Ao ouvi-lo chegar, D. Clemência gritou para a cozinha: Jovita! olhe o correio. Veja si tem carta!

Está aqui Sinházinha! disse a preta, entregando à velha um enveloppe pequenino.

A velhinha abriu-o e deixou transparecer um sorriso.

É de Verinha... O' Jovita, é uma novidade! Ouça! 'Vovó, eu mando um beijo para a senhora, outro para Crespo, outro para a tia Jovita. Estou muito contente, por que aqui em casa ha tres cousas novas: um gato, uma boneca e uma irmãzinha que eu gosto mais! Parece uma bolinha e chamase Thereza...' Mais uma para o anno, tia Jovita! rematou contente, a vovó.

A preta riu-se.

Está aqui, estamos de novo no verão, Sinházinha! Olhe, diga a Verinha que a tia Jovita já vai preparar a cama p'ra irmãzinha, o borralho p'ro gato e os trapos p'ra bruxinha!..." 320

No fim das férias, a despedida era uma tristeza só. As crianças diziam adeus ao sítio, aos demais empregados e, por último, à “Jovita”, que se emocionava chorando pela partida dos netos de sua senhora. Entregava, então, os cobiçados doces que produzia e, novamente, recuperava laivos de sua “dureza” (amolecida pelas lágrimas), advertindo as meninas para que não brigassem pela goiabada.

Dizia, ainda, que jamais se esqueceria das crianças, mas temia que elas, partindo para cidade - e cheias de afazeres e estudos - se esquecessem “das velhas”.

A fala “das velhas” revela uma reciprocidade de situação e, até mesmo, certa identidade entre a negra e sua patroa: as duas, "velhas”, ficariam sozinhas, com saudades das crianças, cuidando da casa e esperando ansiosas até as próximas férias; quando os pequenos retornariam.

Essa identificação da negra com a patroa também é aprovada por esta última. Com efeito, ela compartilhava com "tia Jovita” as notícias recebidas das crianças, chegando a mandar, inclusive, recados da criada aos netos, por meio das cartas que escrevia em resposta.

Na correspondência, os pequenos mandavam beijos e notícias à avó e aos mais chegados - sua “família estendida” -, que a acompanhavam no dia-a-dia da casa: o “cachorro Crespo” e a negra velha "tia Jovita”. Ambos são tratados “como sendo da família”, mas incorporados com 
papéis específicos, seja como animal de estimação, seja como "empregada doméstica/cozinheira” e “companheira da senhora branca”, igualmente velha. Nesse parentesco adquirido por direito consuetudinário, a negra velha torna-se tia, e não mãe, por estar localizada no núcleo de parentesco da avó. Ou seja, por manter relações de intimidade e convivência com a avó das crianças, ela é chamada por estas como “tia”, e não “mãe”.

Uma negra velha que também conta histórias e tem uma relação muito próxima com a família patriarcal, sobretudo com as crianças, também está presente na série do Sítio do Picapau Amarelo; a célebre obra infantil composta por Monteiro Lobato. Trata-se da famosa “Tia Nastácia”. Essa personagem é apresentada no primeiro livro da série, Reinações de Narizinho da seguinte forma:

“Na casa ainda existem duas pessoas - Tia Nastácia, negra de estimação que carregou Lúcia em pequena, e Emília, uma boneca de pano bastante desajeitada de corpo. (...)"321

Com essa introdução, sugere-se que “Tia Nastácia” fora ama de Lúcia, mais conhecida como Narizinho, personagem importante dessa série infantil. Neste serviço, tornara-se íntima e muito querida da família de Dona Benta, daí a razão de ser descrita como "negra de estimação” ou seja, alvo da estima dos moradores da casa. Mas “negra de estimação” também pode ser entendido num sentido próximo ao da expressão “animal de estimação”: uma pessoa leal, resignada e dependente. Essa proximidade afetiva não implicava, portanto, numa relação social igualitária. Outra passagem do livro dá mais pistas sobre a personagem e sobre o lugar que ocupa dentro da família de Dona Benta:

“Criança de hoje, sinhá, já nasce sabendo. No meu tempo, menina assim desse porte andava no braço de ama, de chupeta na boca. Hoje?... Credo! Nem é bom falar... E com a menina dançando à sua frente, Tia Nastácia lá foi para cozinha fritar a traíra." ${ }^{322}$

“Nastácia”, além de negra, é velha e, no (seu tempo) passado, as crianças eram “diferentes”: mais infantis e menos inteligentes, além de serem tratadas de outro modo; à base de colo de ama, quiçá escrava, e chupeta.

O "pronome de tratamento” com que chama a dona do sítio - “sinhá” -, diminutivo de “senhora” revela, mais uma vez, o uso de termos próprios à escravidão, quando indicavam uma relação de posse. Além disso, a função de cozinheira desempenhada por "Nastácia” poderia relacioná-la também ao universo da escravidão doméstica pois, no passado, esse serviço era

\footnotetext{
${ }^{320}$ Idem. p. 180, 183 e 184.

${ }^{321}$ Monteiro Lobato. Reinações de Narizinho. São Paulo, Círculo do Livro, 1936/s.d. p. 6.
} 
realizado pelas escravas. Mas os tempos mudaram, a escravidão terminou, contudo os lugares sociais permanecem bastante semelhantes, e isso se revela pelo termo de etiqueta social: "sinhá".

Mas “Tia Nastácia”, além de ter sido ama da Lucia e cozinhar para os moradores do Sítio, cuida também da lavagem da roupa, aproximando-se, dessa forma, da figura da atual empregada doméstica:

“- Arre, menina! - gritou lá do rio Tia Nastácia, numa dessas vezes. Não chegou quase um mês inteiro de tloc, tloc [o barulho da menina comendo jabuticabas]? Largue disso e venha me ajudar a estender essa roupa que é melhor.

Narizinho (...) foi correndo para o rio, com a Emília de cabeça para baixo no bolso do avental. a preta.

Lá teve uma idéia: deixar a boneca pescando enquanto ela ajudava

- Tia Nastácia, faça um anzolzinho de alfinete para a Emília. Coitada tem tanta vontade de pescar...

- Era só o que faltava! - respondeu a negra, tirando o pito da boca. - Eu, com tanto serviço, a perder tempo com bobagem.

- Faz? - insistiu a menina. (...) Faz?

A negra não teve remédio. Como não hei de fazer, demoninho? Faço, sim... Mas se ficar atrasada no serviço a culpa não é minha. "323

Tanto gostava e cuidava de Narizinho, que "Nastácia” fazia-lhe todas as vontades; mas não sem antes resmungar. A menina, conhecendo sua "negra de estimação”, insiste, e ela cede aos apelos da garota, protestando que lhe atrasaria no restante do trabalho.

Assim, em linhas gerais, pode-se dizer que “Tia Nastácia” é descrita desempenhando um papel próximo ao de uma empregada doméstica, uma vez que cuida das crianças, cozinha e lava. Mas não se sabe se ela era remunerada por tal atividade. A negra, tal como caracterizada na obra de Lobato, sendo muito íntima dos habitantes do Sítio e, ela mesma morando no lugar em que trabalha, assemelha-se mais a uma agregada do que a uma assalariada.

Outro ponto a ser comentado é a relação íntima entre “Nastácia” e “Dona Benta”, talvez se conheceriam de longa data. Mas, além disso, ocupavam papéis semelhantes dentro da casa: as duas são velhas, têm por volta de sessenta anos, cuidam do sítio e das crianças. Essas similaridades ficam evidentes na reciprocidade que as duas mantêm entre si: a cada peripécia das crianças, elas compartilham o espanto. Tal é o caso, por exemplo, quando descobrem que a boneca Emília além de pescar, fala:

\footnotetext{
${ }^{322}$ Idem. p. 41.

${ }^{323}$ Idem. p. 39 e 40.
} 
“- Culpa dela, Dona Benta! Narizinho tirou minha saia para vestir o sapão rajado - disse Emília falando pela primeira vez depois que chegara ao sítio.

Tamanho susto levou Dona Benta, que por um triz não caiu de sua cadeirinha de pernas serradas. De olhos arregaladíssimos, gritou para cozinha:

- Corra Nastácia! Venha ver esse fenômeno...

A boa negra deu uma risada gostosa, com a beiçaria inteira.

- Impossível, sinhá! Isso é coisa que nunca se viu. Narizinho está mangando com mecê.

- Mangando o seu nariz! - gritou Emília furiosa. - Falo, sim, e hei de falar. Eu não falava porque era muda, mas o Doutor Cara de Coruja me deu uma bolinha de barriga de sapo e eu engoli e fiquei falando e hei de falar a vida inteira sabe, sabe?

A negra abriu a maior boca do mundo.

- E fala mesmo, sinhá!... - exclamou no auge do assombro. - Fala que nem uma gente! Credo! O mundo está perdido..."

A primeira pessoa que Dona Benta chama para partilhar seu espanto e confirmar o fenômeno inesperado é “Tia Nastácia”. Talvez seja essa relação próxima entre a "negra” e sua "sinhá” que justifique o termo de "parentesco sociológico” com que é incorporada na família branca: Nastácia é “tia” e não “mãe”. Nessa medida, é por estar mais intimamente relacionada com a avó das crianças, e não diretamente com as crianças, que ela seria chamada de “tia” por elas.

Outra característica que ambas velhas partilham é o fato de contarem histórias às crianças do sítio. No entanto, ainda que próximas e parecidas, há uma diferença de hierarquia entre as personagens. Uma é a avó branca, dona do Sítio; a outra sua empregada, negra, descendente de escravos e cozinheira. Essas diferenças marcantes se fazem presentes também nos tipos de histórias que contam e nas situações em que isso acontece.

Dona Benta é tida como sábia, conhecedora da “alta cultura”, e domina a "literatura escrita, de modo que as histórias que conta são da chamada "alta literatura” estrangeira, que conhecera nos livros. Assim, nos serões da senhora branca, oferecidos de livre e espontânea vontade pela preceptora das crianças, são contadas as histórias de personagens como Peter Pan e Dom Quixote. $^{325}$

Já “Tia Nastácia”, na obra Histórias de Tia Nastácia, realiza um serão quando é pressionada por Pedrinho, que curioso por um artigo de jornal, interessa-se pelo folclore, que é definido por Dona Benta como:

\footnotetext{
${ }^{324}$ Idem. p. 28 e 29.
} 
"folk quer dizer gente, povo; e lore quer dizer sabedoria, ciência. Folclore são as coisas que o povo sabe por boca, de um contar para o outro, de pais para filhos - os contos, as histórias, as anedotas, as superstições, as bobagens, a sabedoria popular, etc. e tal." 326

Pedrinho nota imediatamente que Tia Nastácia seria do “povo”, portanto passa a vê-la como uma possível fonte de folclore a ser explorada. Tal como nas contadoras de histórias analisadas anteriormente, a negra velha é identificada como uma espécie de "corporificação de todo o povo”, com seus saberes tradicionais; logo, é acertadamente fonte de folclore. Tal atitude fica expressa nas palavras do próprio garoto:

“Tia Nastácia é o povo. Tudo que o povo sabe e vai contando de um para outro ela deve saber. Estou com o plano de espremer Tia Nastácia para tirar o leite do folclore que há nela." ${ }^{327}$

Pedrinho ainda se lembra de um fato que confirma sua hipótese:

"Mamãe sempre conta de uma [negra velha] que era um verdadeiro dicionário de histórias folclóricas, uma de nome Esméria, que foi escrava de meu avô. Todas as noites ela sentava-se na varanda e desfiava histórias e mais histórias. Quem sabe se Tia Nastácia não é uma segunda Tia Esméria?"328

A partir desses trechos, percebe-se que Pedrinho identifica a cozinheira do sítio num papel análogo ao de “Tia Esméria”, e tal analogia se faz pelo fato de serem ambas fontes de histórias folclóricas e, também, pela associação tácita dos papéis da antiga escrava e da atual cozinheira negra. Desse modo, novamente nestas fontes, o povo é compreendido como também formado por essas figuras remanescentes da escravidão. A figura de “Tia Esméria” pode ser esclarecida a partir da dedicatória que Lobato fez em O Sacy-Perêrê: Resultado de um inquerito:

"À memória da saudosa tia Esméria, e de quanta preta velha nos pôz, em criança, de cabellos arripiados com histórias de cucas, sacys, e lobis-homens, tão mais interessantes que as larachas contadas hoje aos nossos pobres filhos por umas lambisgóias de touca branca, n'uma algaravia teuto-ítalo-nipônica que o diabo entenda. Vieram estas corujas civilisar-nos; mas que saudades da tia velha que em vez de civilisação requentada a 70\$000 réis por mez, afora bicos, nos apavora de graça!"'329

\footnotetext{
${ }^{325}$ Dona Benta realiza serões em dois livros do Sítio do Picapau Amarelo: Peter Pan (1930) e D. Quixote das Crianças (1936). Para uma comparação mais detida sobre os papéis de narradoras de Dona Benta e Tia Nastácia, vide: Marisa Lajolo. A figura do negro em Monteiro Lobato. Op. cit.

${ }^{326}$ Monteiro Lobato. Histórias de Tia Nastácia. Op. cit. p.7 e 8.

${ }^{327}$ Idem. p.8.

${ }^{328}$ Idem.

${ }^{329}$ Monteiro Lobato. O Sacy-Perêrê: Resultado de um inquerito. Op. cit. s/p.
} 
“Tia Esméria” era uma negra velha que trabalhara na família de Lobato, e que cumprira seu papel como boa contadora de histórias. Fora, ainda, pagem de seu filho Guilherme. Assim, tanto “Tia Nastácia” como “Tia Esméria” eram negras velhas, talvez antigas amas-de-leite, tornadas agregadas - amas-secas - em decorrência do amadurecimento das crianças.

Dessa maneira, soa ainda mais expressiva a frase "espremer Tia Nastácia para tirar o leite do folclore que há nela”. O “leite” da cozinheira alimentaria, então, a “curiosidade gulosa” do menino.

Portanto, o modo como é iniciado esse serão com a negra velha, no Sítio do Pipacau Amarelo, difere bastante daqueles outros existentes nos livros aqui trabalhados. As crianças não se dirigem à “Nastácia” por saberem e reconhecerem nela uma exímia narradora de histórias. Ao contrário, é só a partir de um artigo de jornal (cultura letrada), que falava do folclore (uma ciência) que Pedrinho, desejando investigar (pesquisar) esse novo assunto, recorre à velha cozinheira. “Tia Nastácia” não é, portanto, a tradicional contadora de histórias na casa do sítio. Tal papel cabe, ordinariamente, a Dona Benta. E é só nesse arroubo de interesse científico de Pedrinho que “Tia Nastácia” entra, pressionada, “espremida” no papel de contadora de histórias.

A obra Histórias de Tia Nastácia começa, portanto, com essa pequena introdução em que Lobato justifica a busca e as formas de transmissão das histórias populares. O livro é composto pela transcrição dessas histórias contadas por “Tia Nastácia”, ao final das quais os ouvintes Pedrinho, Narizinho, Emília e Dona Benta - tecem comentários. A estrutura narrativa na forma de serão é, então, aqui aplicada. Após o término da primeira história e dos comentários da audiência, Lobato conclui: "Mas as histórias continuaram. Naquele mesmo serão, Tia Nastácia teve de contar mais uma. E contou a história do Sargento Verde.”330

Das 43 histórias contadas no livro, 36 são retiradas do livro de Sílvio Romero e todas essas são narradas por “Tia Nastácia”. As outras 7 histórias são contadas por Dona Benta narradora tradicional dentro do Sítio - já que ao final do livro a cozinheira foi cuidar do jantar. Essas últimas narrativas são então apresentadas, pela dona do sítio, como pertencentes ao folclore do Cáucaso, da Pérsia, do Congo, dos esquimós, da Rússia, da Islândia e do Rio de Janeiro. Monteiro Lobato deve, portanto, ter utilizado outros livros como fonte. Acaba, no entanto, por não citá-los, como era costume na época. Silvio Romero, diferentemente, é textualmente referido “como um erudito que recolheu essa história da boca do povo de Pernambuco.”331 Ou ainda, no seguinte trecho, em que a própria obra de referência para o texto de Lobato é citada:

\footnotetext{
${ }^{330}$ Monteiro Lobato. Histórias de Tia Nastácia. Op. cit. p.15.

${ }^{331}$ Idem. p.30.
} 
“Ele [Silvio Romero] fez um trabalho muito interessante, que publicou com o nome de Contos Populares do Brasil. Ouvia as histórias das negras velhas e copiava-as direitinho, com todos os erros de língua e os truncamentos. É assim que os folcloristas caçam a obra popular." ${ }^{332}$

Essa menção ao folclorista (e jurista da escola de Recife) confirma o empreendimento de Pedrinho: ele estava certo em procurar na figura de Tia Nastácia - uma negra velha - o folclore, já que o profissional desse campo de estudo procedeu da mesma maneira. Digno de destaque é, também, o próprio método de trabalho do folclorista: ele passa para o registro escrito uma história que só existia, anteriormente, no campo da oralidade. O folclore na obra de Lobato aparece, portanto, como Ciência, como uma investida científica da cultura erudita sobre a popular. Pedrinho, desse modo, leva a cabo esse papel científico no serão de Tia Nastácia. ${ }^{333}$

A personagem conta a primeira história folclórica e, em seguida, a audiência reage, tece comentários, apreciações e, no limite, veredictos. Emília “torceu o nariz”:

“- Essas histórias folclóricas são bastante bobas - disse ela. Por isso que não sou 'democrática'! Acho o povo muito idiota...." 334

A boneca ainda argumenta que pensa dessa maneira, por culpa de Dona Benta, que a havia iniciado nas Ciências e nas Artes. Dona Benta, achando graça na fala de Emília, comenta:

“- Vê Nastácia como está ficando este meu povinho? Falam como se fossem gente grande, das sabidas. Democracia para cá, folclórico para lá, mentalidade... Neste andar, meu sítio acaba virando universidade do Pica-Pau Amarelo." 335

“Tia Nastácia” concorda com Emília, também culpando Dona Benta. Era porque a avó lhes ensinava tantas coisas dos livros que eles (crianças do sítio) acabavam “sabidões” demais.

Aqui ficam evidentes os limites e os embates promovidos pelo recurso aos diferentes saberes. Emília se vê no direito de julgar (como sendo pobre) a história de "Nastácia”, somente porque é iniciada nas Ciências e Artes - na tradição escrita da cultura civilizada. Dona Benta questiona toda essa arrogância e autoridade de juízo de Emília diante dos saberes tradicionais do povo, ao "brincar”, dizendo que o sítio se pareceria com uma universidade - instituição que concentra o saber formal, erudito, e discorre com relativa autoridade sobre todos os outros saberes, inclusive o oral e o popular. E o embate se confirma na voz da cozinheira, que também

\footnotetext{
${ }^{332}$ Idem. p.56.

${ }^{333}$ Nesse sentido, Luiz Demétrio Juvenal Tavares e Oswaldo Orico também realizam o trabalho de um folclorista científico, registrando em livros as histórias que escutaram das bocas de mães-pretas ou negras velhas.

${ }_{334}^{334}$ Monteiro Lobato. Histórias de Tia Nastácia. Op. cit. p.14.

${ }^{335}$ Idem. p.15.
} 
identifica na iniciação à “cultura civilizada escrita dos livros” a empáfia da boneca de se fazer de juiz das histórias.

A maneira com que foi iniciado o serão justifica, em grande parte, a atitude da audiência do sítio. “Tia Nastácia” estava sendo “espremida” para verter, no serão, a sua sabedoria popular. A cozinheira estava na posição de “objeto de pesquisa”, num projeto liderado por Pedrinho. Este encontrava-se interessado, como os intelectuais desde a época de Sílvio Romero, Mello Moraes, Lindolpho Gomes e Basílio de Magalhães, em (re)conhecer as tradições nacionais de seu povo, identificado-as com a escravidão e seu legado.

Nessa medida, a audiência do serão no Sítio - diferente daquela dos outros livros estudados, em que eram crianças maravilhadas pela figura da contadora de histórias - tem caráter “científico”. Ela dá seu parecer, “legitimado pela ciência”, ao final da “extração” de histórias das fontes populares.

A boneca Emília, ao longo de todo o livro, critica ferozmente as histórias de "Nastácia”, classificando-as como “sem pé nem cabeça” ou ainda inferiores às de Andersen ${ }^{336}$ e Caroll. E Dona Benta insistentemente explica que histórias escritas e orais têm lógicas diferentes:
"As histórias que andam na boca do povo não são como as escritas. As escritas conservam-se sempre as mesmas. Porque a escrita fixa a maneira pela qual o autor compôs. Mas as histórias que correm na boca do povo vão se adulterando com o tempo. Cada pessoa que conta muda uma coisa ou outra, e por fim elas ficam muito diferentes do que eram no começo. "337

Porém, essa progressiva adulteração das histórias é vista como prejuízo pela “universitária” Emília. Iniciada no mundo da cultura erudita, a boneca valoriza as histórias próprias à essa realidade, aquelas que possuem autoria comprovada e estabilidade. As histórias populares, que se modificam na boca das suas inúmeras narradoras, perderiam o sentido tornando-se até bobas:

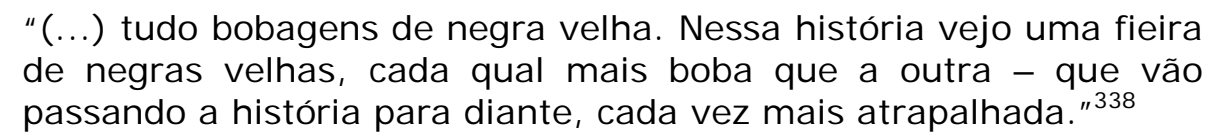

A boneca, estandarte da alta cultura aprendida de Dona Benta, considera-se autorizada a julgar o saber popular como “inferior”. Ela hierarquiza essa relação entre tais saberes. A boneca, acompanhada, na maioria das vezes, por Narizinho, insiste em rebaixar as histórias populares e,

\footnotetext{
${ }^{336}$ Que também, por irônico que pareça, somente trouxera ao registro do livro as histórias que circulavam oralmente pela Europa.

${ }_{337}^{337}$ Monteiro Lobato. Histórias de Tia Nastácia. Op. cit. p.20.

${ }^{338}$ Idem. p.30 e 31.
} 
diante disso, Dona Benta argumenta que não se deve usar o mesmo crivo de análise para as histórias escritas e autorais (mais “artísticas”) e as folclóricas:

"Não podemos exigir do povo o apuro artístico dos grandes
escritores. O povo... Que é povo? São essas pobres tias velhas,
como Nastácia, sem cultura nenhuma, que nem sabem ler e que
outra coisa não fazem senão ouvir as histórias de outras criaturas
igualmente ignorantes, e passá-las para outros ouvidos, mais
adulteradas ainda." 339

Nesse momento, a velha senhora, ao tentar defender uma diferença entre as histórias orais e escritas acaba, tal como Emília, hierarquizando essa comparação. Ao povo não caberia o apuro artístico, esse é próprio aos que tem “cultura”, aos que sabem ler. Do povo, identificado com “Tia Nastácia” e as pobres “tias velhas”, só se pode esperar ignorâncias e adulterações. O povo, metaforizado em “Tia Nastácia”, também é caracterizado como afeito a “crendices” e superstições. Tais sentidos ficam evidentes no diálogo, que ocorre após Narizinho ter confessado sua predileção por histórias cujo personagem era o diabo:

“- Credo! Exclamou Tia Nastácia fazendo três benzeduras. Como é que uma menina de boa educação tem coragem de dizer isso do canhoto?

- Como? É boa! Pois você mesma não acaba de contar a história dum diabo bom?

- Mas isso é história, menina. História é mentira. O 'cão' é o 'cão'. Não muda de ruindade.

- Se o cão é o cão, viva o diabo! - gritou Emília. - Não animal melhor, nem mais nobre que o cão. Chamar ao diabo de cão, é fazer-lhe o maior elogio possível.

- Dona Benta - exclamou Tia Nastácia horrorizada -, tranque a boca dessas crianças. Estão ficando os maiores hereges deste mundo. Chegam até a defender o canhoto, credo!...

- Olhe, Nastácia, se você conta mais três histórias de diabo como essa, até sou capaz de dar um viva ao canhoto - respondeu Dona Benta.

Tia Nastácia botou as mãos e pôs-se a rezar." 340

A negra é descrita, portanto, como religiosa, mas de uma religiosidade absolutamente “popular”, onde o diabo tem muito destaque atemorizando a “incauta Tia Nastácia”. A audiência composta, nesse momento, por Narizinho, Emília e Dona Benta se diverte com as “crendices” da cozinheira. Elas, pessoas iniciadas nas ciências e livros, não acreditavam nessas coisas, tidas como "bobagens de negra velha”.

\footnotetext{
${ }^{339}$ Idem. p. 26.

${ }^{340}$ Idem. p. 58 e 59.
} 
Essas críticas constantes acabam por retirar “Tia Nastácia” do papel de narradora das histórias folclóricas: ela sai sob o pretexto de ir cuidar do jantar. A cozinha é, aliás, o único lugar em que a negra velha possui conhecimentos vastos e autoridade reconhecida. Ao longo do livro são inúmeras as descrições de "quitutes” feitos pela negra; desde "beijus”, “mandioca com melado de rapadura”, “galinha ao molho pardo” e etc. A negra é versada numa vastidão de receitas, algumas delas típicas. E, graças aos seus conhecimentos culinários, as crianças escaparam de enrascadas, como quando "Nastácia” fez bolinhos para o Minotauro. Por ser conhecedora dos segredos culinários, a negra velha mantém seu posto de cozinheira. No entanto, ao se tornar narradora, seus contos que - tal como sua culinária - tinham origem popular, são criticados pelo público iniciado na "alta cultura”. Desse modo, ela perde a função de contadora de histórias - que Dona Benta cumpria melhor -, mas mantém seu posto (menos prestigioso) de cozinheira oficial do sítio.

Dona Benta assume, portanto, o papel de narradora, e passa a contar histórias de outras origens (Cáucaso, Pérsia, Congo, esquimós, Rússia e Islândia), afinal ela não é negra velha e, tampouco, sinônimo de conhecimento popular. Ao contrário, a avó faz parte da elite culta e letrada em conhecimentos universais, não tanto os nacionais. Assim, o único folclore que a avó pode vocalizar é aquele de fora de seu país.

Os veredictos negativos da audiência diminuem então, talvez porque Dona Benta não é vista como “objeto de pesquisa”, e também não é mais a cultura brasileira que está em questão.

A oscilação de posições de Dona Benta - que a princípio defendia uma política de respeito à diferença (às histórias populares), passando depois a considerá-las inferiores em relação às narrativas escritas (artísticas e com autoria) - fica ainda mais clara numa discussão sobre a repetição dos mesmos elementos nas histórias folclóricas.

“É que vêm de muito longe - disse D. Benta. - Se fossem histórias de hoje, teríamos automóveis em vez de forcas, e não veríamos nunca o horrendo castigo do despedaçamento por burros bravos. O povo, muito conservador, repete hoje as mesmas histórias contadas na Idade Média (...).

- Mas se os contadores vão alterando as histórias - disse Pedrinho -, por que conservam essas barbaridades?

- As alterações são só na cor local, em detalhes superficiais. Na essência, no fundo, as histórias não são alteradas. Por isso aparecem tantos príncipes, tantos reis, tanta forca e tanto burro bravo - explicou D. Benta. (...) Os colonizadores portugueses trouxeram essas histórias e soltaram-nas por aqui - e o povo as vai repetindo, sobretudo na roça. A mentalidade da nossa gente roceira está ainda muito próxima da dos primeiros colonizadores.

- Por quê, vovó? 
- Por causa do analfabetismo. Como não sabem ler, só entra na cabeça dos homens do povo o que os outros contam - e os outros só contam o que ouviram. A coisa vem assim num rosário de pais a filhos. Só quem sabe ler, e lê os bons livros, é que se põe de acordo com os progressos que as ciências trouxeram ao mundo." 341

Aqui, a ambigüidade dos posicionamentos de Dona Benta fica ainda mais clara. O povo e suas histórias seriam interessantes mas, conservadores em função do analfabetismo, estariam numa situação desvantajosa, pois desconheceriam os progressos trazidos pela Ciência, e comunicados pela linguagem escrita. A avó defende o povo e suas histórias, mas em tom de tutela. Isto é, ela relativiza as diferenças, ao especificar o que são as histórias escritas e as orais; mas ao explicar o que se pode exigir de cada uma delas, ela acaba por hierarquizar a comparação. É como se Dona Benta, compreendendo que a "fieira de negras velhas analfabetas" são um resultado do estado calamitoso da educação, as protegesse. Daí, serem os julgamentos de Emília tomados como injustiça, e incitarem explicações da “consciente” vovó.

Essa indefinição (ou ao menos mal-estar) de Dona Benta com relação ao “povo” e suas histórias, lembra muito de perto o impasse enfrentado por Lobato diante da figura do Jeca nas décadas de 20 e 30. As primeiras obras de Lobato, que têm como personagem o Jeca Tatu, trazem-no de modo bastante pejorativo, qualificando-o como "piolho e praga da terra”, “(...) o Jeca Tatu e seu mundo constituem verdadeiros símbolos de um atraso econômico, político e mental que, no entender de Lobato, devia ser vencido”. ${ }^{342}$ Ao longo de suas obras, porém, o autor passa a apostar no progresso e na modernização do Brasil (preocupações típicas desse pensamento de época), transpondo, então, as dificuldades inatas do Jeca (uma raça degenerada), e passando a encará-lo como problema a ser tratado pela Saúde Pública, pelo saneamento, pelo higienista. ${ }^{343}$ Esse saneamento, contudo, não se limita a uma profilaxia médica, mas é também acrescido de um diagnóstico “cultural”, de uma carência educacional que precisava urgentemente ser suprida. Porém, ao mesmo tempo em que o Jeca precisava ilustrar-se para que adentrássemos

\footnotetext{
${ }^{341}$ Idem. p.64.

342 André Luiz Vieira de Campos. A República do Picapau Amarelo. São Paulo: Martins Fontes, 1986. p. 21.

343 Monteiro Lobato foi classificado como herdeiro da "geração de 1870", também conhecida como "geração angustiada”. Junto com ele, nesta categoria, estão incluídos Euclides da Cunha, Lima Barreto, entre outros. A angústia seria característica desses autores, uma vez que aparentemente não conseguiam encaixar a realidade brasileira - que tanto primavam em suas obras - nas categorias forjadas no paradigma racialista. Lobato entrara em contato com essas idéias, sobretudo as de Gustave Le Bon, entre 1895 e 1904, enquanto estudava Direito no Largo São Francisco. Tal angústia advinha, também, da produção de uma literatura engajada, uma "literatura como missão”, que focava a realidade visando transformá-la, modernizá-la, mas esbarrando num consenso conceitual sobre o povo brasileiro, um povo inferior. É no ínterim desse raciocínio que encontramos os dilemas de Lobato diante da figura do Jeca e posteriormente de Tia Nastácia. Ver, para maiores informações a esse respeito, André Luiz Vieira de
} 
a Modernidade, ele também seria símbolo do tipicamente nacional, de nossa cultura autêntica, que ainda possuiria seus encantos.

Para o Brasil se modernizar, tanto os “Jecas” quanto as "Nastácias” deveriam sair do limbo do analfabetismo, para compartilhar dos progressos que as ciências e a Modernidade poderiam fornecer. Mas ao mesmo tempo, “Jecas e Nastácias” são o próprio "povo”, e suas histórias fazem parte da mentalidade "autêntica” desse mesmo “povo”, dessa realidade, que singularizaria a nação. Desse modo, pode-se pensar que se trata de um mergulho naquilo que é mais “tradicional” (ou “popular”), que permitiria entender sua lógica, para em seguida propor meios para transpor esse estágio. Assim Lobato procedeu com o “Jeca”, indicando os mesmos rumos para as “Nastácias”. Pedrinho desde o início expusera esse raciocínio:

“Pois eu gostei da história [folclórica] porque me dá idéia da mentalidade do nosso povo. A gente deve conhecer essas histórias como um estudo da mentalidade do nosso povo." ${ }^{1344}$

Povo esse que o autor paulista quer educar e alfabetizar; não para substituir suas histórias, mas para incluir outras - as artísticas e autorais - em seu repertório. Portanto, pode-se dizer que as variações e nuances dos posicionamentos de Lobato frente ao popular (e folclórico) versus o moderno, encontram em Dona Benta o lugar para serem expressas dentro do sítio, podendo transmiti-las também às crianças e pais de todo o Brasil. Dona Benta tal como Lobato, titubeia diante do popular, diante da sabedoria de “Tia Nastácia”; ora defendo-a, ora depreciando-a, como pertencente à parcela ignorante da população.

Mas num sentido mais profundo, foi na forma de sua obra monumental para crianças, que Lobato resolveu de maneira equilibrada essa tensão entre localismo e cosmopolitismo. É num ambiente tipicamente regional - no “interior” - que se desenrolam as histórias do sítio, o qual é descrito como um cenário permeado de jabuticabeiras, cambucazeiros, jaqueiras, pés de sapoti, pinto-suras, sabiás, sanhaços, sagüis, capivaras, onças, Curupiras, Boitatás, ex-escravos, negras quituteiras e etc. No entanto, esse espaço tão bem descrito como um “cantinho” do Brasil, é invadido a todo momento pelo mundo moderno, com suas sabedorias e progressos; e isso acontece por meio das histórias do mundo que Dona Benta adapta e conta aos habitantes do sítio. Histórias e conhecimentos do mundo que chegam pelos livros, pela alfabetização, pela educação formal e por uma preceptora (Dona Benta) capaz de compreender os livros do mundo, mesmo quando trazidos para realidade brasileira.

Campos. Op. cit. Para maiores detalhes dessa "literatura como missão" ver. Nicolau Sevcencko A Literatura como missão: tensões sociais e criação cultural na Primeira República. São Paulo, Companhia das Letras, 1983/2003. 
Talvez, Lobato tenha um papel análogo a esse, de preceptor, ao compor sua obra para as crianças brasileiras: ele adapta as histórias do mundo para os infantes locais, iniciando-os também (e ao mesmo tempo) em nossa realidade e nosso povo.

As “negras velhas”, “contadoras de histórias”, “cozinheiras e agregadas” da família, são personagens de um tempo em que a escravidão já acabara. No entanto, essa instituição deixou marcas muito profundas, que permaneceram no trato social do ambiente privado da casa, lugar de trabalho das negras velhas cozinheiras. E nesse trato cotidiano do ambiente doméstico, elas acabam por tornar-se agregadas da família dos patrões. Estabelecidos e tecidos com múltiplos sentimentos afetuosos recíprocos, os termos de tratamento específicos da escravidão permanecem revelando, também, certa semelhança entre os papéis da empregada / agregada doméstica e o da escrava doméstica.

Nesse sentido, abundam "sinhás”, “ioiôs”, “comadres” e "tias”, termos que selam esse “parentesco consuetudinário”, estabelecido pela convivência de trabalho no ambiente doméstico, pelas relações íntimas, e até mesmo pela simetria entre brancos e negros nos papéis desempenhados cotidianamente. No entanto, quando se instaura a simetria imediatamente se reafirma a diferença.

Assim, nos livros comentados no segmento "negras velhas contadoras de histórias" as “negras velhas contadoras” já não eram diretamente ligadas ao universo da escravidão. “Totonia” vivia de contar histórias, ganhando, portanto, algum dinheiro com isso. "Sá Dondom” e "Vovó Candinha” eram afamadas na vizinhança por serem excelentes regentes de serões. No entanto, as “negras velhas cozinheiras e agregadas da família” branca, ainda que pertencessem a um universo social de pós-abolição, estão imersas em categorias próprias do mundo escravista. O que leva a pensar que o locus em que se desempenha a narração de histórias implica num maior ou menor afastamento do tratamento dispensado às negras nos tempos do cativeiro. Se os serões acontecem na casa dos patrões, a associação tácita entre “negras velhas” e “amas escravas” fica ainda mais evidente.

Além disso, novamente essas negras velhas são associadas a “conhecimentos específicos” - populares ou tradicionais - fossem as narrativas folclóricas, fosse uma culinária típica. Elas são, portanto, versadas nessa sabedoria que em meados da década de 1930 auxiliava a composição da chamada “cultura nacional”. Essas “negras cozinheiras” iniciavam as crianças nas características

\footnotetext{
${ }^{344}$ Monteiro Lobato. Histórias de Tia Nastácia. Op. cit. p.14.
} 
típicas do país; são nessa medida "civilizadoras”. No entanto, elas também são ignorantes da “alta cultura”, “das ciências”, “da modernidade” que igualmente compunham essa “civilização”. Nessa medida, surgem como "negras velhas”, "incautas” e crentes num "misticismo popular”, que a essa altura se tornava motivo de chacota.

\section{“Negras velhas” são o Povo”}

“O povo... Que é povo? São essas pobres tias velhas, como Nastácia, sem cultura nenhuma, que nem sabem ler e que outra coisa não fazem senão ouvir as histórias de outras criaturas igualmente ignorantes, e passá-las para outros ouvidos, mais adulteradas ainda."1345

A representação da mãe-preta na literatura infantil brasileira no contexto dos anos 1930 é um objeto privilegiado, uma vez que permite discorrer sobre os dilemas da intelectualidade, diante dos rumos desejados para o Brasil. Isso se expressa, na medida em que as obras desse tipo de literatura desenham e descrevem compreensões sobre o que seria importante - e legítimo - ser ensinado para as crianças brasileiras, futuros cidadãos da nação em formação.

Na década de 1930, a grande voga é a de um movimento intelectual em busca de uma definição da “cultura nacional”. Há, portanto, uma ênfase deliberada em uma certa cultura tradicional, no folclore e no popular, os quais exerceram uma forte influência no delineamento da literatura infantil do período. Nessa medida, para a transmissão desses saberes folclóricos, tradicionais e populares, a “negra velha”, agregada da família ou não, aparece como personagem dileta e, sobretudo, verossímil. Isso porque ela surge como sinônimo de “povo”, e é dele que emanam tais conhecimentos. Por “povo” entenderia-se tudo aquilo que não é elite, que não é Ciência, cultura letrada e erudita, ou mesmo européia. A noção de povo inclui, portanto, as “negras velhas”, agregadas e demais figuras vinculadas ao imaginário da escravidão.

Seguindo essa lógica, a “vovó”, a “mamãe branca”, ou o “professor”, não são narradores adequados para essas histórias. O “professor” não narra os mesmos causos que “Sá Dondom”. “Dona Benta”, tampouco, conta a mesma espécie de histórias que “Tia Nastácia”; seu papel de branca e de mulher iniciada na alta cultura lhe permite narrar histórias folclóricas européias. Possibilita-lhe, ainda, explicar cientificamente a razão pela qual as histórias de “Tia Nastácia” são pobres; mas jamais contar as histórias, que são criação popular, e exprimem o “espírito do povo”.

Desse modo, falar da representação da mãe-preta e das “negras velhas” na literatura infantil brasileira da década de 1930 é, principalmente, entrar no universo da contadora de

${ }^{345}$ Idem. p. 26. 
histórias folclóricas, repleto de bichos da fauna brasileira, de encantamento, de assombrações e de magia e misticismo. Mas as “negras velhas”, além destas histórias, transmitiam outros ensinamentos "típicos da terra”. Falavam sobre as festas ligadas a um catolicismo popular: os “presepes”, os “pastoris”, as “cheganças”, os “côcos” e o “bumba-meu-boi”. Eram, também, conhecedoras de uma “culinária” específica e tradicional, de quitutes regionais, tais como: os doces de tacho - goiabadas e cocadas -, as "mandiocas com melado de rapadura” e os pratos baianos - “manauê de milho verde”, “arroz de côco” e "beijú”.

As descrições que os literatos fazem das atividades realizadas pelas "negras velhas” são extremamente adjetivadas. São “exímias” e “incomparáveis” contadoras de histórias que têm “técnicas narrativas” que arrebatam os espectadores. Suas comidas são especiais, e só elas conhecem os segredos de seu preparo. Essas personagens têm, portanto, muita “cultura” e “sabedoria” para transmitir às crianças. Mas o repertório em que elas são versadas é o popular, o folclórico.

Nessa medida, num contexto de formação da cultura nacional - definida pelos elementos mestiços e populares - as “negras velhas” surgem como agentes civilizadores. Isso porque, iniciam as crianças no “fabulário popular”, em uma “culinária típica” e nas festas de um calendário do "catolicismo popular”. Em resumo, inculcam nos pequenos as contribuições do “povo” - formado, também, por negros e ex-escravos - para a mestiça civilização brasileira.

Nesse processo, evidentemente uma certa escravidão é idealizada e outra esquecida. A “escravidão dócil” transforma-se em sinônimo de especificidade local e as revoltas, quilombos, fugas e insurreições somem da lembrança; ou não se vinculam a essa representação que vai se tornando oficial.

No entanto, essas "negras civilizadoras” são igualmente descritas como ingênuas, incautas e crentes num misticismo popular - por vezes, “ignorantes” -, pois desconhecem a “alta cultura”, ou mesmo, a “norma culta”. Ainda neste caso, segundo Lobato, elas são “civilizáveis”: podem ser alfabetizadas e educadas de modo a compartilhar "os progressos da Ciência” com os brancos. A personagem de Isabel, filha de Quitéria, parece confirmar essa teoria. Ela freqüentava a escola, onde aprendia a "recitar quadrinhas” sobre o Treze de Maio. Além disso, a “pretinha” aprendera com sua "patroinha branca” como a Abolição da escravidão fora uma "dádiva” de "uns homens piedosos e da princesa boa”. Dail também lhe ensinara uma outra lição: uma vez que não havia mais escravidão, não importava que fosse “pretinha”; se fosse "boa”, seria querida tal qual uma "branca”. 
Dessa forma, a literatura infantil do período, por meio das negras velhas, transmite o “manual de época” sobre como tratar os negros, reconhecendo neles uma "humanidade” e uma “bondade”, tais quais os brancos as possuíam. Em outras palavras, significava tratá-los “como se fossem brancos” lembrando-os, imediatamente, que eram "pretinhos”. Este "manual de boas maneiras raciais" fica evidente quando se atenta para os "pronomes de tratamento" utilizados pelas “negras agregadas” ao se referirem à família branca: "sinhazinha”, “sinhá” e “ioiô”. São todos termos advindos da escravidão; que identificam os patrões como indivíduos hierarquicamente superiores; e, por contrapartida, enquadram as negras num status “naturalmente” inferior.

Por fim, essas obras revelam a contradição implícita nesta valorização dos elementos “negros e mestiços” da cultura popular: a manutenção da diferença e da hierarquia entre brancos e negros.

Concluindo, os primeiros passos para a formação, no Brasil, de uma literatura voltada para o público infantil foram dados durante a Belle Époque, quando se procurava adaptar e traduzir os contos e histórias estrangeiros, sobretudo suas versões portuguesas ${ }^{346}$. No entanto, é só na década de 1920, coadunado a um movimento mais geral pela definição da cultura nacional, que Lobato inicia seu empreendimento na literatura infantil, o qual acaba por tornar-se um marco de formação. Mas esse exercício, pela primeira vez literariamente criativo nesse segmento direcionado às crianças, resultou das pesquisas que o autor realizou sobre o folclore nacional e seus personagens (presentes, por exemplo, na obra Sítio do Picapau Amarelo). Nessa medida, é com um resgate paradoxal do folclore nacional - que conta com a contribuição seletiva e “controlada” dos negros e ex-escravos - que se forma uma literatura infantil brasileira na década de 1930. E, neste gênero literário, as “negras velhas” ambíguas são eleitas como representação predileta.

Esse resgate do folclore nacional acontece de maneira paradoxal porque a própria concepção de “povo brasileiro” era ambígua. O estudo do que veio a se chamar, a partir de 1856, de "folklore", já ocorria de maneira disseminada pela Europa desde o século XVIII. Este estudo compreendia, sobretudo, costumes e tradições populares. Foi o inglês William John Thoms que usou o termo pela primeira vez, quando escreveu para a revista The Atheneum "as suas páginas mostraram amiúde o interesse que toma por tudo quanto chamamos, na Inglaterra, 'Antigüidades Populares', 'Literatura Popular'(embora seja mais precisamente um saber popular que uma literatura, e que poderia ser, com mais propriedade, designado com uma boa palavra anglo-

\footnotetext{
${ }^{346}$ Sobre essa nacionalização da literatura (seja dos livros infantis ou dos de “sensações”), que passava pela indústria do livro de Portugal vide: Alessandra El Far. Páginas de Sensação. São Paulo, Companhia das Letras, 2004.
} 
saxônica, Folk-Lore, o saber tradicional do povo) e que não perdi a esperança de conseguir a sua colaboração na tarefa de recolher as poucas espigas que ainda restam espalhadas no campo no qual os nossos antepassados poderiam ter obtido uma boa colheita...”347

Essa conexão (e quase intercambialidade) entre literatura e sabedoria, defendida por Thoms, tem sua inspiração nas idéias do pensador alemão Herder; elas, assim como os costumes e as tradições de um povo, também integravam o volksgeist - o espírito do povo. No entanto, grande parte do "povo brasileiro" não era livre até 1888. Deste modo, a recuperação da "sabedoria” ou do "espírito" do povo brasileiro implica numa leitura e numa seleção desse mesmo povo, que até muito pouco tempo era escravo. Portanto, recupera-se apenas parte de sua sabedoria tida como "típica", ao mesmo tempo em que se exclui parte de seu "espírito" considerado pouco "moderno ou civilizado".

\footnotetext{
${ }^{347}$ Apud Carlos Rodrigues Brandão. O que é Folclore. São Paulo, Brasiliense, 1984. p.27.
} 


\section{CONSIDERAÇÕES FINAIS: MÃES-PRETAS E AS DIVERSAS MATERNIDADES BRASILEIRAS}

“A Mãe Negra é mãe da criança branca, da criança negra, da criança pobre, da criança nordestina. Mãe Negra ensina que quando damos amor, somos acolhidos também.” (Pe. Bogaz, Missa da Mãe Negra, 21/05/2006)

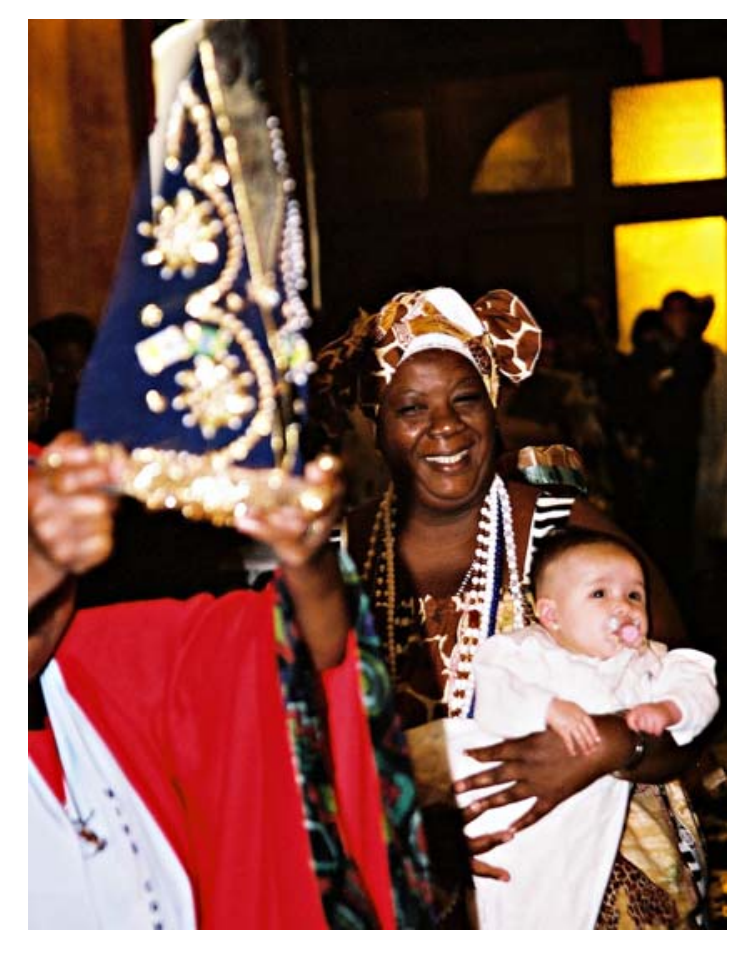

A imagem negra de Nossa Senhora da Conceição Aparecida com seu manto azul majestosamente bordado em dourado é carregada pelo ministro da Pastoral Afro, antecedendo e preparando o caminho para a entrada da homenageada da missa solene: a "Mãe Negra". Ela vem a seguir: trata-se de uma senhora negra, robusta, com largo sorriso no rosto, de trajes afro, devidamente paramentada com colares e pano estampado à cabeça; traz em seu colo uma criança branca. Mãe negra de filho branco. Essa foto, que materializa algumas das representações trabalhadas nessa dissertação, foi tirada em São Paulo, no dia 16 de maio de 2004, no bairro do Bexiga. Mais especificamente, na Igreja de Nossa Senhora Achiropita. Trata-se da "Missa da Mãe Negra” (chamada "Mãe Preta" alguns anos antes) que a Pastoral Afro Achiropita realiza desde 1990, no terceiro domingo do mês de maio. ${ }^{348}$

\footnotetext{
348 Acompanhei a missa da Mãe Negra nos anos de 2004, 2005 e 2006. Nessas considerações finais não faço, contudo, uma análise do ritual católico; apenas recupero a figura da mãe-preta nesse contexto específico para a realização de um paralelo importante e, ao mesmo tempo, provocativo. Para escrever essa pequena etnografia fiz uso
} 
A data, por si só, já é reveladora. Maio, no calendário litúrgico católico, é o mês dedicado a Maria; no segundo domingo do mês de comemora-se o Dia das Mães; e o terceiro domingo do mês de maio cai, invariavelmente, numa data próxima do dia 13 de maio: Abolição da escravatura $^{349}$. O dia da celebração, numa sobreposição de significações, agrega Maria ou Nossa Senhora mãe de Jesus Cristo (em sua versão negra, Nossa Senhora da Conceição Aparecida); as mães de todo Brasil e, sobretudo, as “Mães Negras”, aquelas que eram escravas e foram libertadas pela Abolição.

A “Missa da Mãe Negra” é a maior festa promovida pela Pastoral Afro, que realiza ao longo do ano outros eventos, tais como: Missa de São Benedito, Missa de Nossa Senhora da Conceição, Benção da Escola de Samba Vai-Vai ${ }^{350}$, Missa do dia Internacional de Luta contra o Racismo, Missa de Cosme e Damião, Missa de Zumbi dos Palmares, além de batizados afro. Assim, é significativo e curioso que a maior festa dessa Pastoral - que possui membros ligados ao Movimento Negro - dedique-se à figura da "Mãe Negra”, e não à imagem de Zumbi, símbolo maior da "luta dos negros” no Brasil.

A missa em questão, celebrada desde 1990, pode ser compreendida como uma "tradição inventada”; não exatamente nos termos propostos por Hobsbawm ${ }^{351}$, que sugerem uma idéia tácita de falseamento e manipulação. Mas sim, “invenção”, no sentido de Roy Wagner ${ }^{352}$, que implica em destacar elementos como a imaginação e a criação, sempre a partir de valores préexistentes. Nessa medida, quando em 1990, a Pastoral Afro-Achiropita iniciou as comemorações da missa da "Mãe Negra”, ela buscou, de alguma maneira, elementos no repertório de sentidos pré-existentes e associados a essa personagem. E, ao fazê-lo, inventou sua própria versão da “Mãe Negra”. Essa versão que envolve, por sua vez, a referência a outros significados da “Mãe Negra”, está expressa e celebrada no ritual da missa. Vamos a ela...

A celebração começa ao som de atabaques e berimbaus. Os membros da Pastoral entram na igreja trazendo um grande cruz e os santos homenageados; entre eles estão São Benedito e a

do excelente "Relatório de Pesquisa - Missa da Mãe Negra: O lugar dos elementos afro-brasileiros na construção do negro católico" realizado pelas alunas Camila Boldrin Beltrame, Gilsa Rojas Barreto e Marília Zaroni Nicolella, (São Paulo, FFLCH, 2004) para a disciplina "Pesquisa de Campo em Antropologia", ministrada pelo Prof. Dr. Vagner Gonçalves.

${ }^{349}$ Aliás, numa impressionante confluência de elementos simbólicos, a Igreja de Nsa. Sra. Achiropita está localizada na Rua Treze de Maio.

${ }^{350}$ A escola de Samba Vai-Vai também fica no bairro do Bexiga e muitos membros da Pastoral Afro fazem parte dela.

${ }^{351}$ Eric Hobsbawn e Terence Ranger. A invenção das tradições. São Paulo, Paz e Terra, 1997/2002.

${ }^{352}$ Roy Wagner. The Invention of Culture. Chicago, University of Chicago Press, 1981. 
Nossa Senhora de Aparecida - ambos santos negros. Em seguida, entram as baianas da Vai-Vai devidamente trajadas -, carregando velas perfumadas, defumadores e ervas; elas seguem em direção ao altar e sentam-se nas cadeiras laterais. Na seqüência, os líderes religiosos convidados adentram pelo corredor principal da igreja, são eles: Pai Cláudio de Oxossi, o Babalorixá Francisco de Ogum e a Mãe Conceição.

A seguir, Padre Toninho, responsável pela implantação da Pastoral Afro Achiropita, dá as boas vindas à assembléia, e pede para que todos se voltem para o fundo da igreja. Neste momento, anuncia a entrada da "Mãe Negra”, que foi recebida em 2004, com a música Negra Mariama (negra maria-ama); e em 2005, ao som de Senhora Negra, Ya querida, Soberana Quilombola, Mãe de Deus Aparecida. Nas duas canções há uma explícita conexão entre a figura da “Mãe Negra” e “Maria”, também expressa na santidade negra de Nossa Senhora Aparecida. Na primeira, a negra é um misto de “ama” com a figura de "Maria”; na segunda, "Mãe de Deus Aparecida” é uma senhora negra e “soberana num quilombo”. Desse modo, Nossa Senhora é remetida ao universo da escravidão brasileira.

Na missa, a representação da “Mãe Negra” é “incorporada” por Dona Joana ${ }^{353}$, que em seu colo carrega uma criança branca; uma filha branca da "mãe negra”. Ela também está acompanhada de seus filhos negros, que caminham a seu lado, portando "trajes afro". Todos se sentam junto aos regentes, no altar, lugar de honra para a homenageada. Na acolhida, são apresentados os diversos líderes religiosos presentes e mencionam-se os nomes dos “memoráveis ancestros”; todos ligados ao movimento negro.

A celebração corre como de hábito, à exceção das músicas, que são todas marcadas por “temáticas afro". Algumas versam inclusive sobre a "Mãe Negra”, tal como a que apresento abaixo, a qual cumpria a função de "Salmo Responsorial”354:

\footnotetext{
${ }^{353}$ Ela também pertence à ala das baianas da escola de Samba Vai-Vai.

${ }^{354}$ Faço aqui um pequeno resumo das partes que compõem o ritual de uma missa solene. Nos Ritos Iniciais temos: abertura (música cantada por todos, para a recepção do padre e líderes religiosos convidados), saudação (a assembléia faz o sinal da cruz), ato penitencial (momento de reflexão e quando se pede o perdão), hino de louvor (canta-se o "Glória a Deus” e recepciona-se a Mãe Negra), oração (lida pelo padre). Liturgia da Palavra: primeira leitura (feita por um membro da pastoral afro), salmo responsorial (cantado pelo coral e pela assembléia), segunda leitura (feita por outro membro da pastoral afro), aclamação ao evangelho (cantada pelo coral e pela assembléia), evangelho (leitura feita pelo padre com a assembléia em pé), homilia (feita pelo padre e líderes religiosos convidados, com a assembléia sentada), profissão de fé (todos rezam o credo), orações dos fiéis (membros da pastoral afro lêem as diferentes preces), Liturgia Eucarística: apresentação das oferendas (música com procissão de comidas, além do pão e do vinho), oração sobre as oferendas (feita pelo padre), oração eucarística (feita pelo padre, com a assembléia em pé e ajoelhada, momento de oração e apresentação do corpo e sangue de Cristo). Ritos da Comunhão: pai-nosso (rezado por todos), canto da comunhão (cantado por todos, enquanto os fiéis se dirigem ao padre e líderes religiosos convidados; para receber a comunhão), oração após a comunhão (feita pelo padre). Ritos Finais: benção (feita pelo padre e líderes religiosos convidados), canto final (todos cantam o "Canto das Três Raças”,
} 


\author{
“MÃE PRETA \\ Pele encarquilhada carapinha branca \\ Gandôla de renda caindo na anca \\ Embalando o berço do filho do sinhô \\ Que há pouco tempo a sinhá ganhou \\ Era assim que mãe preta fazia \\ criava todo o branco com muita alegria \\ Porém lá na senzala o seu Pai J oão apanhava \\ Mãe preta mais uma lágrima enxugava \\ Mãe preta, mãe preta \\ Enquanto a chibata batia no seu amor \\ Mãe preta embalava o filho branco do sinhô \\ Mãe preta, mãe preta"355
}

A música cantada como Salmo retoma alguns elementos já mencionados nas fontes analisadas. "Mãe preta” é descrita como uma escrava desgastada e velha - de "pele encarquilhada” e “carapinha branca” - que “embalava” e “criava” os filhos recém-nascidos de suas sinhás brancas. E, novamente, o modo como ela realizava essas funções é digno de nota e atenção: com “muita alegria”. A canção sugere, ao mesmo tempo, uma “mãe preta” abnegada, pois se doa “alegremente” para o filho branco; enquanto "Pai João” (seu amor) era castigado, por ordem dos senhores a quem ela servia como ama.

Na música, mesmo diante desse quadro de violência cometida contra seu ente querido, "mãe preta” não se revolta. Tal é sua "santidade e passividade”, que ela se resigna a consolar "Pai João” e a cumprir “amorosamente” sua função de “mãe preta”.

Na homilia, um dos padres convidados - Padre Renato - pertencente a uma igreja do bairro, reflete e explica a figura da Mãe Negra:

"As crônicas do Brasil que falam da Mãe Negra versam sobre o colo da Mãe Negra, sobre os peitos da Mãe Negra que fizeram crescer com alegria os homens fortes que são os milhões de negros do Brasil de hoje. Mas a Mãe Negra, na história, não se limitou a criar os filhos dos negros. Ela fez mais. Ela criou os filhos dos brancos, filhos dos fazendeiros, aqueles portugueses heróis, que lá na Europa tinham feito um país bonito. País de liberdade, mas lá na Europa fria, era uma Europa de leis.

Mas agora eles estavam aqui. E tinham vindo para cá, não para criar um país, mas para explorar a riqueza e levar para lá; assim como fizeram os

e ocorre a procissão de saída com membros da Pastoral Afro, a Mãe Negra e seus filhos, o padre e os lideres religiosos convidados).

${ }^{355}$ Autor (Letra): Piratini, Compositor (Música): Caco Velho, Ano da primeira gravação: 1943 
outros colonizadores espanhóis. Os filhos dos fazendeiros e proprietários nunca iam poder viver neste país.

Mas aqui neste lugar Deus tinha um projeto. Deus quis criar aqui um país livre, de alegria, de vida. Habituados em um país europeu e frio eles não iam conseguir viver nesta terra de sol e de fraternidade, que era o que Deus queria. Eles precisavam de uma mãe (...)

A Mãe Negra da minha família chamava Jovita, que foi a minha avó nascida em uma fazenda de escravos. A minha bisavó veio de Angola. Mão negra, para nós brasileiros, tem nome! Eu tenho certeza que cada um que está aqui - e tem sangue negro - a Mãe Negra para ele tem nome, não é Pe. Toninho?

- A sua Mãe Negra como chamava?

- Maria!

[pergunta para outros regentes]

A Mãe Negra para nós tem nome, é de carne e osso, de sangue, de coração, de vida. Elas nos criaram. Mãe Negra abençoada!

A vossa Mãe Negra católica, também tem nome: ela chama Maria, chama Aparecida; Mãe Negra de povo branco!

Quantas Mães Negras! ... Mãe Menininha do candomblé da Bahia... temos que lembrar de uma porção de nomes de mães que vivem junto conosco. Quanta coisa para lembrar. Que Deus abençoe todas as mães negras antigas e as mães negras de hoje; e também as futuras que estão se formando." 356

Nesse sermão, reúnem-se diversos sentidos, ou mesmo, diferentes representações da “Mãe Negra”. Algumas delas relembram, outras contradizem, certos significados atribuídos à figura, no decorrer desta dissertação.

A “Mãe Negra” surge como uma personagem histórica, sempre presente nas crônicas que falam do Brasil. O padre evoca, portanto, as amas-de-leite do tempo da escravidão, que tinham seus colos e peitos narrados publicamente; não só nas crônicas, como nos anúncios de jornal. Entretanto, a “Mãe Negra” não é uma escrava vitimizada em sentido óbvio. Ao contrário, ela é valorizada por ter criado exemplarmente milhões de homens "negros, fortes e alegres do Brasil”. Assim sendo, nesta passagem, a ama-de-leite escrava é, eminentemente, uma mãe-negra de filho negro.

Em um exacerbamento do papel que já cumpria tão bem, "Mãe Negra”, em sua “desmedida generosidade”, "não se limitou a criar os filhos dos negros”, passando a cuidar, igualmente, dos filhos dos brancos. É numa atitude "voluntária” e de “piedade” que a mãe-negra cria os filhos dos brancos, que do contrário não sobreviveriam. Ela se doa, em "auto-sacrificio”, por meio de seus seios, para prover essas crianças.

\footnotetext{
356 Transcrição apud relatório de pesquisa Missa da Mãe Negra: o lugar dos elementos afro-brasileiros na construção do negro católico. Op. cit. p.28 e 29. Grifos meus.
} 
Neste momento, o padre enfatiza “o papel civilizador” que essas personagens históricas tiveram na promoção de uma nação (para a qual Deus tinha seus planos) miscigenada. A “Mãe Negra” "aclimataria” os filhos dos portugueses brancos, acostumados ao frio da Europa, adaptando-os a essa "pátria quente e fraterna”. A mãe-negra, portanto, ao criar "seu” filho branco - ao civilizá-lo - faria dele uma espécie de “mestiço”, que sobreviveria nessa terra "quente e de alegria”. Nesse sentido, “Mãe Negra” lembra as mães-pretas e “negras velhas” das fontes estudadas; as quais - no período entre 1880 e 1950 - por meio do leite, dos cuidados e da sua sabedoria “tradicional” e "folclórica” (histórias, misticismo, festas populares, culinária típica) tornavam as crianças brancas, pequenos mestiços. Deste modo, parafraseando Silvio Romero, todo brasileiro se tornava um mestiço, se não no sangue, ao menos nas idéias. ${ }^{357}$

Segundo o citado Padre Renato, além de “figura histórica”, a “Mãe Negra” é também “real”. É integrante da rede de parentesco dos afro-descendentes: “a mãe negra para eles tem nome”. Todos que têm “sangue” negro possuiriam “mães-negras” "biológicas” como ascendentes.

Todavia, a "maternidade” não era definida apenas pelo “sangue”. As “mães-negras” “reais” - de “carne” e “osso” - além de mães de sangue, eram “mães de coração”, “de vida” e “de criação”. Deste modo, a maternidade também é determinada por "afetividade”, “por manutenção da vida” e "pelos cuidados que acompanham o crescimento das crianças”. Esses diversos elementos definidores de uma relação materna estavam expressos nos textos dos literatos, o que tornava a mãe-preta um ser "híbrido”358 - fazendo um paralelo com o conceito de Latour -, uma vez que mesclava natureza (leite, sangue) com cultura (afetividade e cuidados).

Padre Renato evoca, ainda, um outro componente constituidor dessa "maternidade negra”: a religiosidade. Ser católico no Brasil implicaria em ter outra "Mãe Negra”: Nossa Senhora da Conceição Aparecida. Deus nos presenteara com uma mãe-preta espiritual. Nossa Senhora Aparecida, como todas as Nossas Senhoras, é Maria, mãe de Jesus. Maria sacrificara seu filho pela humanidade; enquanto o sacrifício da "Mãe Negra” fora a escravização. E, mediante tal arbítrio, ela teria dado um exemplo de fé e caridade cristãs: criou os filhos de seus próprios algozes, sacrificando - em algumas ocasiões - seu próprio rebento negro.

Estes sacrifícios foram, ao mesmo tempo, realizados em prol da edificação da pátria brasileira mestiça. Desta maneira, a mãe-preta, ao dividir seus peitos, semeara a fraternidade

\footnotetext{
${ }^{357}$ A frase original é “todo brasileiro é um mestiço, se não no sangue, nas idéias”. Sílvio Romero apud Lilia Moritz Schwarcz. O espetáculo das raças. São Paulo, Companhia das Letras, 1993/2000. p. 154.

${ }^{358}$ Bruno Latour. . Jamais Fomos Modernos. São Paulo, Editora 34, 1994.
} 
entre brancos e negros e criara um país mestiço. Tal processo é selado em 1930, com a escolha de Nossa Senhora da Conceição Aparecida para padroeira do Brasil, “Mãe Negra” de um país mestiço. A Mãe Negra, assim como a Pátria-Mãe brasileira, tem filhos de cores diversas ${ }^{359}$.

Retornando à homilia de Padre Renato, há uma derradeira “Mãe Negra”; trata-se de "Mãe Menininha”, que representa as mães-de-santo do candomblé. Regente dos cultos afro-brasileiros ela, do mesmo modo, é “Mãe Negra” espiritual daqueles que professam essa religião, seus filhosde-santo. E uma vez que candomblé e umbanda são, atualmente, religiões de conversão universal, reúnem dentre sua prole espiritual, fraternalmente, filhos brancos e filhos negros. Esta religião passou a ocupar "legalmente” seu lugar - de “contribuição negra para a pátria mestiça” na década de 1930, quando deixou de ser perseguida pela polícia. ${ }^{360}$

Como se vê, o ritual vai afinando uma religião mestiça de um povo mestiço, fazendo com que um elemento retome e reforce o outro.

No sermão da missa afro, são os filhos negros de mãe-preta que falam. E eles se autorepresentam como “muito bem criados” e “cuidados” por essa mãe-negra escrava. Ela, ainda, no “cumprimento dos planos de Deus”, e num "transbordamento de caridade e amor cristão pelo próximo”, adotou os filhos dos brancos como sendo os seus próprios.

O estranhamento inicial diante do fato de ser a "Mãe Negra” a grande homenageada da Pastoral Afro - e não uma figura "mais política” como Zumbi - desfaz-se diante desse raciocínio. A “Mãe Negra” oferecera o verdadeiro exemplo de uma conduta cristã a ser seguida exemplarmente, cumprindo com resignação, semelhante à de Maria, os desígnios que Deus lhe dera.

Deve-se observar que, pela primeira vez nesta dissertação de mestrado, a figura da "Mãe Negra” surge enquanto uma auto-representação feita pelos próprios negros; no caso, negros católicos. Pode-se, inclusive, arriscar que ao realizar essa re-interpretação da figura, fica mais evidente como a mãe-preta não era apenas uma versão branca (ideologicamente manipulada), para a escravidão negra. Ela parece se apresentar como uma figura que ocupa um lugar consistente na “memória social” nacional, girando em torno da escravidão e do legado do negro

\footnotetext{
${ }^{359}$ Sobre essas múltiplas conexões de Nossa Senhora de Aparecida (com a figura da mãe, da mãe do povo, do povo brasileiro e mestiço, que clama o padroado dessa mãe preta) que culminam com seu padroado durante o governo Vargas; vide: Juliana Beatriz de Almeida. "Mãe negra de um povo mestiço: devoção a Nossa Senhora Aparecida e identidade nacional”. In: Estudos Afro-Asiáticos. n. 29. Rio de Janeiro, 1996.

${ }^{360}$ Letícia Vidor de Souza Reis. "A aquarela do Brasil: reflexões preliminares sobre a construção nacional do samba e da capoeira” in: Cadernos de Campo, n. 3, São Paulo, 1993.
} 
para a pátria. Por outro lado, em função da mesma ambigüidade que notei no material, ela também assume múltiplas versões ritualísticas, dependendo do contexto no qual é acionada.

Na missa, a “Mãe Negra” é uma “mártir”. Uma católica exemplar e generosa que, mesmo submetida à escravidão, é capaz de cumprir sua missão divina, criando filhos brancos e negros. A representação nela encarnada revela, nesse caso, como os negros são “bondosos”, “civilizados” e “civilizadores”, permitindo a própria sobrevivência do branco, e o surgimento de uma pátria mestiça. Como sugere essa interpretação, ela jamais é vítima; é, no máximo, sofredora, e cumpridora dos desígnios de Deus por meio desse sacrifício.

Deve-se observar que essas representações da mãe-preta não são, de maneira alguma, exemplos isolados. Segundo George Reid Andrews, foi concebendo-a como “negra civilizadora”, que as organizações negras, do início do século XX, veneravam a figura. Elas enalteciam figuras que representavam a contribuição dos negros para a história e para formação da nação brasileira: “até a década de 1950, o Dia da Mãe Preta foi comemorado em 28 de setembro, data em que foi aprovada, em 1871, a Lei do Ventre Livre. Em, 1955, a prefeitura erigiu uma estátua da Mãe Preta perto da Igreja do Rosário, historicamente a mais antiga congregação negra de São Paulo. Na década de 1960, o Clube 220, auxiliado por alguns cultos de candomblé de São Paulo, começou a comemorar o Dia da Mãe Preta em 13 de maio, com festividades realizadas no local da estátua”. 361

O intervalo de tempo citado por Andrews coincide, de alguma maneira, com o recorte temporal selecionado para essa pesquisa ${ }^{362}$. Como procurei demonstrar, na literatura desse período, a mãe-preta, mesmo em suas variações, sugere a existência de negras “civilizadas” e “civilizadoras”.

Quando caracterizadas como mães-pretas de filhos brancos - tão "bondosas”, “carinhosas”, “fieis”, que possuíam relação íntima e afetiva com a família branca - elas tinham uma "moral”, muito semelhante àquela das mulheres brancas. No entanto, justamente por essa proximidade com o status superior, a diferença voltava a ser marcada: era mãe, mas era preta; civilizada, mas de linguagem africana; quase branca em virtudes, mas escrava.

As mães-pretas da literatura eram também “civilizadas” em outro sentido: elas cumpriam as regras de “civilidade” impostas por seus senhores “liberais”. Caso conseguissem deixar de ser escravas - mesmo que trabalhassem por isso - deveriam ser gratas por tal condição. A liberdade

\footnotetext{
${ }^{361}$ George Reid Andrews. Negros e Brancos em São Paulo (1888 - 1988). Bauru, EDUSC, 1998. p. 335 e 336.

${ }^{362} \mathrm{O}$ autor comenta o intervalo entre 1900 - 1960, e meu recorte abrange a literatura brasileira, entre 1880 - 1950.
} 
seria, portanto, dádiva que só poderia ser doada por pessoas valorosas e moralmente superiores, fossem seus senhores, ou a princesa Isabel.

Na função de civilizadoras - e carregando tal posição de prestígio -, transmitiram ensinamentos religiosos, histórias folclóricas, culinária típica e festas de um catolicismo popular; mas eram, ao mesmo tempo, ingênuas, incautas e ignorantes da "regra culta” e da "alta cultura”, essa sim Civilizada.

Desta forma, mesmo durante a voga do modernismo e da era Vargas, em que o mestiço (mãe-preta, produtora de mestiçagem), o popular e o típico (mãe-preta, versada nesse conhecimento) são definidores do nacional, a mãe-preta, as "negras velhas” e as “cozinheiras agregadas”, seguem sendo socialmente inferiores.

A literatura dessa época revela, portanto, uma homologia com a sociedade. Em ambas, ainda que os elementos negros e mestiços fossem incorporados como definidores da cultura nacional, isso não implicou na alteração do quadro de desigualdade entre brancos e negros.

Nesse sentido, nas obras dos literatos brancos, as mães-pretas e as suas variações são suportes de significações que revelam a maneira como a escravidão não foi entendida apenas como violência e arbítrio. A mãe-preta representa, nesse sentido, o lugar "possível” da afetividade. E também, ela simbolizaria a contribuição cultural dos negros; até hoje entendida como uma das “medidas do que é autêntico” e nacional. Tais constatações não implodiram, contudo, a hierarquia entre brancos e negros.

Talvez seja por algumas dessas razões que, dentro do movimento negro, a mãe-preta passou, progressivamente, a perder espaço para a figura de Zumbi. Segundo Andrews, a personagem passa a ser vista pelos ativistas como "a resposta submissa e acomodada dos negros à escravidão"; já Zumbi, é entendido como "a resistência corajosa e engajada ao regime escravo". ${ }^{363}$ Para o militante Hamilton Cardoso, a mãe-preta distorceria as realidades do trabalho escravo e do serviço doméstico. Buscando justificar a exploração das mulheres negras, em suas palavras: “a Mãe Preta transformou-se em heroína nacional quando deixou de amamentar seus filhos para alimentar de 'leite materno’o filho do senhor de escravo, deixando que as mães brancas mantivessem belos seus seios 'superiores'. A mãe negra, na imagem de uma mulher gorda e velha e com grandes tetas, parecendo uma vaca leiteira, ganhou até uma estátua no Largo do Paissandu, em São Paulo”. 364

\footnotetext{
363 George Reid Andrews. Op. cit. p. 337.

${ }^{364}$ Hamilton Cardoso apud George Reid Andrews. Op. cit. p. 336.
} 
Essa fala de Hamilton Cardoso mostra que a sua interpretação da mãe-preta se aproxima muito daquela expressa pelos seguidores da Escola de Sociologia Paulista, entre os quais se encontrava Sonia Maria Giacomini. Em sua obra Mulher e Escrava ${ }^{365}$, a mãe-preta é considerada uma "mistificação ideológica” que recobre as condições reais de trabalho da mulher escrava.

Contudo, conforme argumentei ao longo desse trabalho, enquanto as representações sociais, o imaginário e a memória coletiva forem vistos apenas como resultado (ou reflexo) das relações econômicas "clarividentes", continuaremos ignorantes sobre os processos de interação dos agentes sociais. Pois eles agem no mundo, tendo as representações e os valores como mediadores. ${ }^{366}$ Nessa medida, se mãe-preta fosse tomada apenas por ideologia, não haveria como entender o sentido existente em sua apropriação pelos negros católicos, e a permanência dessas representações sociais seria ininteligível.

Apostando no rendimento do estudo das representações sociais, gostaria de realizar um exercício comparativo, já latente nas fontes. Trata-se de averiguar as simetrias e diferenças entre as representações da mãe-preta e da "Princesa Isabel, a Redentora”. Esta comparação se justifica, uma vez que ambas personagens são símbolos do panteão nacional que tematizam a escravidão e a negritude.

A representação popular de "Isabel, a Rendentora”367, em linhas muito gerais, retraça a figura quase mítica da "princesa abolicionista". Essa representação passou a ganhar fôlego, sobretudo, a partir de 1921, com as reportagens sobre a morte da Princesa, que recuperavam seus feitos. Em 1938, o cinqüentenário da Abolição também contribuiu para a manutenção de Isabel no imaginário da pátria. Desse modo, "a pátria não poderia ficar sem o seu totem cívico. Neste sentido, é que retornaram ao país em 1953, os esquifes do casal d'Eu, recebidos pelo Presidente Getúlio Vargas”. 368

Todos esses momentos, assim como trasladação dos esquifes - em 1971, centenário da Lei do Ventre Livre - que ficaram expostos na Igreja do Rosário, evocam a figura de uma "bondosa” princesa que por "piedade” aos escravos abolira a escravidão. Mas ao realizar esse ato humanitário, Isabel acabou por perder o poder. Ela sacrificara, portanto, o trono e o seu poder político em prol dos negros desfavorecidos. Tal como Cristo no Calvário que se sacrificara pelo

\footnotetext{
${ }^{365}$ Sonia Maria Giacomini. Mulher e Escrava: uma introdução histórica ao estudo da mulher negra no Brasil. Rio de Janeiro, Vozes, 1988.

${ }_{366}$ Recentemente, o conceito de "raça”, rechaçado enquanto realidade biológica, passou a ser entendido como representação social, histórica e política.

${ }^{367}$ Robert Daibert Junior estuda em detalhes o processo de construção da representação de Isabel, como "redentora". Vide a esse respeito: Robert Daibert Junior. Isabel, a "Redentora dos Escravos. Bauru, Edusc, 2004. Sobretudo capítulo 3: "Sob olhares negros e brancos: sepultamento, ressurreição e ascensão da 'Redentora' ”
} 
seu povo, “A Redendora” se sacrificava pelos seus súditos explorados, integrantes de seu povo. Além disso, ao assinar a lei Áurea, a princesa ajudara a fundar a nação brasileira, na medida em que o povo passava a ser composto por brancos e negros; não mais por senhores e escravos.

A representação de "Isabel, a redentora” adquire - nessa versão ora popular, ora oficial o sentido de uma espécie de “mãe branca” dos filhos pretos, os escravos. Tal relação de maternidade seria, nesse imaginário, definida pelos sentimentos de “caridade”, “justiça”, “piedade” e “doação”. Era uma maternidade abnegada, que implicava num sacrifício próprio: sua coroa. Mas ela o realizara para "fundar” uma pátria com brancos e negros irmanados. Como se vê, nessa mitificação histórica, não há conflito, não há jogos de poder ou interesse; apenas dádivas e contra-dádivas: negros que se “doam” pela pátria e a "Princesa Redentora” que “abdica” da coroa por seus súditos "sofridos”.

Mãe-preta, por sua vez, nessa chave se pareceria com um simétrico inverso da representação de “Isabel, a redentora”. Mãe-preta de filhos brancos, sua relação materna é definida por “leite” e inúmeros “cuidados”. Ela constituía, da mesma forma, uma maternidade abnegada, uma vez que implicava no seu próprio sacrifício - como escrava - e de seu filho negro. Contudo, por ser "boa” e "resignada”, ela se sacrifica para criar os filhos da pátria brasileira. Além disso, ao criar filhos brancos e negros ela teria fundado um sentimento de fraternidade entre eles. No caso da mãe-preta, também há uma redenção envolvida, contudo ela não é sua artífice. Sua representação limita-se, tão somente, a ser redimida, seja pelos senhores “bondosos”, pela princesa ou pela sociedade que a reconheceu como um elemento que contribuiu para a formação dessa cultura mestiça.

Desta maneira, se ambas representações envolvem a redenção dos negros, isso significa que eles precisam ser expiados de seu grande “demérito”, a escravidão. Tanto a abolição, quanto o modelo de nacionalidade - que reconhece os negros como parte criadora da nação - são momentos de “expiação” pública da escravidão e da idéia de inferioridade do negro. Porém, e o que é no mínimo paradoxal, no plano privado esses sentidos continuam ativos produzindo novas significações e contrastes crescentes.

Durante a escravidão, a diferença hierarquizada entre brancos e negros era pública e institucionalizada. Contudo, os brancos mantinham relações íntimas e de afeto com os escravos, sobretudo os domésticos, entre os quais estava a ama-de-leite, ou mesmo, a mãe-preta. Tais relações íntimas e afetivas, por vezes humanizavam o “outro” escravo, que em certas ocasiões,

\footnotetext{
${ }^{368}$ Idem. p. 241.
} 
ascendiam ao status de libertos, ou agregados. Mas ainda assim, eles mantinham-se “diferentes”: eram “gratos” e “ex-escravos”. Ainda que livres, conservavam as “marcas”, ou melhor, a “cor”, e a condição da escravidão e da diferença.

Depois da abolição, negros e brancos tornam-se publicamente iguais. Entretanto, a cor e a desigualdade continuam a marcar a diferença inscrita nos corpos. O uso corrente de termos como “pretinho” e “negrinho” revelam esse processo. O diminutivo evidencia uma relação próxima e afetiva; porém, pontuada por uma distinção fundamental: o “preto”, o “negro”.

Durante a era Vargas, a cultura nacional, reconhecida em termos mestiços - ou mesmo por meio da efetiva divulgação de uma convivência harmoniosa entre brancos e negros - não encerrou a obra de "expiação" da negritude como sendo uma "marca de diferença”. Ao contrário, ela permaneceu, só que ativa, principalmente, apenas no plano privado, e nas diferenças econômicas e sociais. Assim, no plano público, somos assumidamente uma "democracia racial”: brancos e negros convivem e se misturam de variadas maneiras. Porém, na dimensão privada, a “diferença” do negro, que remete à idéia de sua suposta inferioridade, continua ativa. Esta é a dita peculiaridade do racismo à brasileira. ${ }^{369}$ Um racismo que não é de evitação do negro, mas sim de hierarquia diante dele.

Aqui, a partir da figura da mãe-preta resvalei nesse racismo peculiar. Partindo do pressuposto de que as representações se encarnam na realidade e são a própria realidade que constituem, a mãe-preta é uma boa janela para se pensar essa modalidade de racismo praticada no Brasil, e que contempla, sempre, a ambigüidade. Afeto não anula a violência; proximidade não elimina a diferença.

Partindo dessa constatação, penso que o conceito de hierarquia, tão utilizado durante esta dissertação, torna-se ainda mais operativo para tratar desta questão espinhosa. Mas, refiro-me à hierarquia tal como definida por Louis Dumont ${ }^{370}$. Segundo sua acepção, hierarquia é uma relação de oposição entre englobante e englobado. Desse modo, no momento da abolição da escravatura - ou no período de reconhecimento da cultura nacional como sendo mestiça -, os

\footnotetext{
${ }^{369}$ Há um vasto debate em torno do tema do racismo no Brasil. Indico apenas algumas obras que apontavam para essa discussão do racismo à brasileira. Entre elas: Florestan Fernandes. A integração do negro na sociedade de classes. São Paulo, Ática, 1964/1978. Oracy Nogueira. Tanto preto quanto branco: estudos de relações raciais. São Paulo: T.A. Queiroz, 1985. Carlos Alfredo Hasenbalg. Discriminação e Desigualdades Raciais no Brasil. Rio de Janeiro, Graal, 1979. Lilia Moritz Schwarcz. "Nem preto nem branco, muito pelo contrário: cor e raça na intimidade”. in: Lilia Moritz Schwarcz (org.) História da vida privada no Brasil- volume 4. São Paulo, Companhia das Letras, 1998/2006. Peter Fry. A persistência da raça. Rio de Janeiro, Civilização Brasileira, 2005. Um bom guia que pontua o debate mais atual está nos diferentes artigos de Racismo I - Revista da USP. São Paulo, CCS/USP, dezembro-janeiro-fevereiro, 2005-2006. $\mathrm{n}^{\circ} 68$.

${ }^{370}$ Louis Dumont. Homo Hierachicus: o sistema de castas e suas implicações. São Paulo, Edusp, 1966/1992.
} 
"brancos" ou a "sociedade nacional” cumprem o papel do englobante. Eles englobam o negro seja na sociedade civil, seja na nação - mas esse englobamento resulta, imediatamente, numa oposição hierárquica.

O mesmo se passava com a mãe-preta: quando era englobada no núcleo de parentesco da família branca - quando se tornava “mãe” - ela, ao mesmo tempo, em oposição hierárquica à mãe branca, tornava-se "mãe-preta”. 


\section{FONTES}

ALVES, Antonieta Borges. Brasil - Canção. São Paulo, Escolas Profissionais Salesianas, 1954.

ANJOS, Augusto dos. “Eu” in: Toda Poesia. Rio de Janeiro, Paz e Terra, 1912/1978.

ARAUJO, Murillo. A illuminação da vida. Rio de Janeiro, sem editora, 1927.

BARROS, Maria Paes de. No tempo de dantes. São Paulo, Paz e Terra, 1998.

BILAC, Olavo \& NETO, Coelho. Contos Pátrios para crianças. Rio de Janeiro, Francisco Alves \& Cia, 1894/1918, $16^{\mathrm{a}}$ edição.

BOPP, Raul. Urucungo. Rio de Janeiro, Ariel, 1932.

CORREA, Viriato. Cazuza. São Paulo, Companhia Editora Nacional, 1938.

COSTA, Cyro. Terra Promettida. Rio de Janeiro, José Olympio Editora, 1938.

DELFINO, Luiz. Poesia Completa - tomo I e II. Florianópolis, Academia Catarinense de Letras, 2001.

FONTES, Ofélia \& FONTES, Narbal. Pindorama - leitura para os alunos dos cursos primário e ginasial. Rio de Janeiro, Fernandes \& Rohe, 1932.

JARDIM, Luís. O Boi Aruá. Rio de Janeiro, Livraria José Olympio Editora, 1940/1970.

1976.

. O meu pequeno mundo. Rio de Janeiro, Livraria José Olympio Editora,

LIMA, Jorge de. Poemas Negros. Rio de Janeiro, Editora da Revista Acadêmica, 1947.

LOBATO, Monteiro. O Sacy-Perêrê: Resultado de um inquerito. Gráfica JB S.A., Rio de Janeiro, 1918/1998. Edição fac-similar.

. Reinações de Narizinho. São Paulo, Círculo do Livro, 1936/s.d.

. "Histórias de Tia Nastácia”. In: Sítio do Picapau Amarelo. Ribeirão Preto,

Editora Brasiliense, 1937 /s.d. (Edição de Luxo).

MORAES FILHO, Mello. "Poemas da Escravidão" in: Cantos do Equador. Rio de Janeiro, Garnier Livreiro-Editor, 1881/1900.

NABUCO, Joaquim. "Massangana” in: Minha Formação. Rio de Janeiro, Clássicos Jackson, 1900/1964.

ORICO, Oswaldo. Contos da Mãe Preta - adaptados à leitura das crianças. Rio de Janeiro, Bibliotheca Infantil d'O Tico-Tico, série I, volume I, 1932. 
. Historias de Pae João - Contos do folk-lore brasileiro adaptados à leitura das crianças. Série I, vol.11. Bibliotheca Infantil d'O TICO-TICO, Rio de Janeiro, [1933].

PIRES, Cornélio. Quem conta um conto... E outros contos (coisas de outrora). São Paulo, Livraria Liberdade, 1915/1943.

. Conversas ao pé do fogo (páginas regionaes). São Paulo, Graphico-Editora Monteiro Lobato, 1921/ 1924.

REGO, José Lins do. Menino de Engenho. Rio de Janeiro, Livraria José Olympio Editora, 1932/1980.

. Histórias da Velha Totonia. Rio de Janeiro, Livraria José Olympio Editora, 1936. . Meus Verdes Anos. Rio de Janeiro, Editora Nova Aguilar S.A., 1987.

REZENDE, Francisco de Paula Ferreira. Minhas Recordações. Rio de Janeiro, José Olimpio, 1944.

RICARDO, Cassiano. "Vamos caçar papagaios" in: Poesias Completas. Rio de Janeiro, Editora José Olympio, 1926/1957.

Edição Saraiva, 1928/1962.

Martim Cererê: O Brasil dos meninos, dos poetas e dos heróis. São Paulo,

RODRIGUES, Wilson W. Pai João Menino. Rio de Janeiro, Arca Editora, 1945/1949. $3^{\text {a }}$ Edição.

TAVARES, Luiz Demétrio Juvenal. Serões da Mãe Preta - Contos populares para crianças. Belém, Fundação Cultural do Pará Tancredo Neves, 1890/1990.

VELLOSO, Maria Alves. As férias com a vovó. Rio de Janeiro, Livraria Francisco Alves, 1932. 


\section{BIBLIOGRAFIA}

ALENCASTRO, Luiz Felipe de. "Vida privada e ordem privada no Império" e "Epílogo" in: ALENCASTRO, Luiz Felipe de (org.). História da vida provada no Brasil - volume 2. São Paulo, Companhia das Letras, 1997/ 2002.

ALMEIDA, Juliana Beatriz de. "Mãe negra de um povo mestiço: devoção a Nossa Senhora Aparecida e identidade nacional”. In: Estudos Afro-Asiáticos. n. 29. Rio de Janeiro, 1996.

ANDREWS, George Reid. Negros e Brancos em São Paulo (1888 - 1988). Bauru, EDUSC, 1998.

ARAÚJO, Íris Morais \& DEIAB, Rafaela de Andrade. Militão Augusto de Azevedo ou formação de um imaginário paulista: olhando retratos e vistas urbanas. 2002, mimeo.

ARAÚJO, Ricardo Benzaquem. Guerra e Paz. Casa-Grande \& Senzala e a obra de Gilberto Freyre nos anos 30. Rio de Janeiro, Editora 34, 1994.

ARROYO, Leonardo. Literatura Infantil brasileira: ensaio de preliminares para sua história e suas fontes. São Paulo, Edições Melhoramentos, 1968.

AZEVEDO, Militão Augusto de. Militão: São Paulo - Álbum Comparativo da Cidade de São Paulo (1862-1887). Prefeitura do Município de São Paulo, 1981.

BARTHES, Roland. A câmara clara. Rio de Janeiro, Editora Nova Fronteira, 1984.

. O óbvio e o obtuso. Rio de Janeiro, Editora Nova Fronteira, 1990.

BASTIDE, Roger. A Poesia Afro-Brasileira. São Paulo, Martins Fontes, 1943.

. "A incorporação da poesia africana à poesia brasileira". In: Poetas do Brasil. São Paulo, Edusp, 1946/ 1997.

. "Doçura do Leite das Negras” in: Letras e Artes - Suplemento literário do jornal A Manhã. Rio de Janeiro, 22/02/1948.

BELTRAME, Camila Boldrin; BARRETO, Gilsa Rojas \& NICOLELLA, Marília Zaroni. Relatório de Pesquisa - Missa da Mãe Negra: O lugar dos elementos afro-brasileiros na construção do negro católico. São Paulo, FFLCH, 2004. mímeo.

BOSI, Alfredo. História concisa da literatura brasileira. São Paulo, Cultrix, 1994.

BRANDÃO, Carlos Rodrigues. O que é Folclore. São Paulo, Brasiliense, 1984.

CALMON, Pedro. Historia do Brasil vol. 5 - século XIX, o império e a ordem liberal. Rio de Janeiro, José Olympio, 1959.

CAMPOS, André Luiz Vieira de. A República do Picapau Amarelo. São Paulo, Martins Fontes, 1986. 
CANDIDO, Antonio. Formação da Literatura Brasileira. São Paulo/ Belo Horizonte, Edusp/Editora Itatiaia, 1957/1975

Publifolha, 1965/2000.

."Literatura e cultura de 1900 a 1945” in: Literatura e Sociedade. São Paulo, v.2, $\mathrm{n}^{0} 4,1984$.

. “A Revolução de 1930 e a Cultura”. In: Novos Estudos Cebrap. São Paulo,

CARDOSO, Fernando Henrique. Capitalismo e Escravidão. São Paulo, Difel, 1962.

CASTRO, Hebe Mattos de. Das cores do silêncio: os significados da liberdade no Sudeste escravista - Brasil século XIX. Rio de Janeiro, Nova Fronteira, 1998.

CHALHOUB, Sidney. Visões da liberdade: uma história das últimas décadas da escravidão na corte. São Paulo, Companhia das Letras, 1990.

CHARTIER, Roger. A História Cultural - entre práticas e representações. Lisboa/Rio de Janeiro, Difel/Bertrand Brasil, 1990.

COELHO, Nelly Novaes. Panorama Histórico da Literatura Infantil/Juvenil. São Paulo, Edições Quíron, 1985.

Edusp, 1995.

Dicionário crítico da literatura infantil e juvenil brasileira. São Paulo,

COSTA, Emília Viotti da. Da senzala à colônia. São Paulo, Editora Unesp, 1998.

COSTA, Jurandir Freire. Ordem Médica e Norma Familiar. Rio de Janeiro, Edições Graal, 1979.

COUTINHO, Afrânio \& SOUSA, J. Galante de. Enciclopédia de Literatura Brasileira. São Paulo/Rio de Janeiro, Global / Fundação Biblioteca Nacional/ Academia Brasileira de Letras, 2001. vol. II. p. 1394.

CUNHA, Manuela Carneiro da. Negros Estrangeiros. São Paulo, Brasiliense, 1985.

. "Sobre os silêncios da lei: lei costumeira e positiva nas alforrias de escravos no Brasil do século XIX” in: Manuela Carneiro da Cunha. Antropologia do Brasil. São Paulo, Brasiliense, 1987.

. “Olhar Escravo, Ser Olhado”. In: Paulo Cesar de Azevedo \& Mauricio Lissovsky (orgs.). Escravos brasileiros do século XIX na fotografia de Christiano Jr. São Paulo, Ex-Libris, 1988.

DAIBERT JUNIOR. Robert. Isabel a “Redentora” dos escravos. Bauru, Edusc, 2004.

DEIAB, Rafaela de Andrade. “A memória afetiva da escravidão” in: Revista de História da Biblioteca Nacional. Ano 1, n 4, outubro de 2005. p. 36-40. 
DUBOIS, Philippe. O ato fotográfico. Campinas, Papirus, 1994.

DUMONT, Louis. Homo Hierarchicus: o sistema de castas e suas implicações. São Paulo, Edusp, 1966/1992.

DURHAM, Eunice. A Dinâmica da Cultura. São Paulo, Cosac \& Naify, 1984/2004.

DURKHEIM, Émile. As Formas Elementares da Vida Religiosa. São Paulo, Editora Paulus, 1989.

EL FAR, Alessandra. Páginas de Sensação. São Paulo, Companhia das Letras, 2004.

EL-KAREH, Almir Chaiban. "Famílias adotivas, amas-de-leite e amas-secas e o comércio de leite e de carinho na corte do Rio de Janeiro" in: Gênero: Núcleo Transdisciplinar de Estudos de Gênero - NUTEG. Niterói, EdUFF, 2004. Vol. 4, n. 2.

ELKINS, Stanley. Slavery: A Problem in American Institutional and Intellectual Life. New York, Universal Library, 1959.

FERNANDES, Andréa Godim. Velhos engenhos de minha terra. Recife, Editora Asa, 1986.

FERNANDES, Florestan. A integração do negro na sociedade de classes. São Paulo, Ática, $1964 / 1978$.

Nacional, 1971.

.\& BASTIDE, Roger. Brancos e Negros em São Paulo. São Paulo, Editora

FERREIRA, Luzilá Gonçalves. "Um capítulo à parte: as amas de leite escravas” in: Luzilá Gonçalves Ferreira et alli. Suaves Amazonas: mulheres e abolição da escravatura no nordeste. Recife, Editora Universitária/UFPE, 1999.

FLORENTINO, Manolo. Paz nas Senzalas. Rio de Janeiro, Arquivo Nacional, 1995.

FRANÇA, Jean M. Carvalho. “O negro no romance urbano oitocentista”. In: Estudos AfroAsiáticos, Rio de Janeiro, n.30, dez., 1996.

FREYRE, Gilberto. Casa-Grande \& Senzala. Rio de Janeiro, Record, 1933/2001.

. O escravo nos anúncios de jornais brasileiros do século XIX. São Paulo, Companhia Editora Nacional, 1961/1979. $2^{a}$ edição aumentada.

Massangana, 1989.

O velho Felix e suas 'Memórias de um Cavalcanti'. Recife, Editora

FRY, Peter. A persistência da raça. Rio de Janeiro, Civilização Brasileira, 2005.

GENOVESE, Eugene. Roll, Jordan, Roll: the world the slaves made. New York, Panteon Books, 1974. 
Terra, 1988. v.I.

. A terra prometida: o mundo que os escravos criaram. Rio de Janeiro, Paz e

GIACOMINI, Sonia Maria. “A conversão da mulher em mãe: uma leitura do 'A Mãi de Família”” in: Revista Brasileira de Estudos de População. Campinas, vol. 2 n. 2, 1985.

. Mulher e escrava: uma introdução ao estudo da mulher negra no Brasil. Petrópolis, Vozes, 1988.

. \& MAGALHÃES, Elizabeth K.C. de. “A escrava ama-de-leite: anjo ou demônio” in: Carmen Barroso \& Albertina Oliveira Costa (orgs.). Mulher, mulheres. São Paulo, Cortez Editora/ Fundação Carlos Chagas, 1983.

GOMES, Angela de Castro. “As aventuras de Tibicuera: literatura infantil, história do Brasil e política cultural na Era Vargas” in: Brasil República - Revista da USP $N^{0}$ 59. São Paulo, set/out/nov 2003.

GOULART, José Alípio. Da palmatória ao patíbulo: castigos de escravos no Brasil. Rio de Janeiro, Conquista, 1971.

. Da fuga ao suicídio: aspectos da rebeldia de escravos no Brasil. Rio de Janeiro, Conquista, 1972.

GRAHAM, Sandra Lauderdale. Proteção e Obediência. São Paulo, Companhia das Letras, 1992.

GUTMAN, Herbert G.. The Black Family in Slavery and Freedom, 1750-1925. New York, Random House, 1976.

HALBWACHS, Maurice. A Memória Coletiva. São Paulo, Vértice, 1990.

HASENBALG, Carlos Alfredo. Discriminação e Desigualdades Raciais no Brasil. Rio de Janeiro, Graal, 1979.

HOBSBAWM, Eric \& RANGER, Terence. A Invenção das Tradições. São Paulo, Paz e Terra, 1997/2002.

IANNI, Otavio. As metamorfoses do escravo. São Paulo, Difel, 1962.

JUNKES, Lauro. “Luiz Delfino: esboço biográfico” in: Luiz Delfino. Poesia Completa: sonetos, tomo I. Florianópolis, Academia Catarinense de Letras, 2001.

LAJOLO, Marisa. “A figura do negro em Monteiro Lobato”. In: Presença Pedagógica. São Paulo, Editora Dimensão, 1998. v.4 n. 23 set/out.

LATOUR, Bruno. Jamais Fomos Modernos. São Paulo, Editora 34, 1994.

LEÃO, Andréa Borges. Brasil em Imaginação - Livros, Impressos e Leituras Infantis (18901915). São Paulo, Tese de Doutorado em Sociologia, FFLCH-USP, 2002. 
LEITE, Miriam Moreira. Retratos de Família. São Paulo, Edusp, 2000.

LÉVI-STRAUSS, Claude. Antropologia Estrutural. Rio de Janeiro, Tempo Brasileiro, 1975.

LISSOVSKY, Maurício \& AZEVEDO, Paulo César de (orgs.). Escravos brasileiros do século XIX na fotografia de Christiano Jr. São Paulo, Ex-Libris, 1988.

LUNA, Luiz. O negro na luta contra a escravidão. Rio de Janeiro, Leitura, 1968.

MAUSS, Marcel. “Uma categoria do espírito humano: a noção de pessoa, a de 'eu’”. in: Marcel Mauss. Sociologia e Antropologia. São Paulo, Cosac \& Naify, 2003.

MELO, Luis Correia de. Dicionário de Autores Paulistas. São Paulo, 1954.

MENDES, Miriam Garcia. A personagem negra no teatro brasileiro. São Paulo, Editora Ática, 1982.

MENDES, Ricardo. CD-Room Militão Augusto de Azevedo e a cidade de São Paulo. Link “Fotografando com Militão”. São Paulo, Museu Paulista -USP/Fundação Roberto Marinho, 1997.

MENEZES, Raimundo de. Dicionário literário brasileiro. Rio de Janeiro, LTC, 1978.

NOGUEIRA, Oracy. Tanto preto quanto branco: estudos de relações raciais. São Paulo, T.A. Queiroz, 1985.

PRADEZ, Charles. Nouvelles études sur les Brésil. Paris, Ernest Thorin Éditeur, 1872.

PRADO JUNIOR, Caio. Formação do Brasil Contemporâneo. São Paulo, Brasiliense, 1942/1987.

QUEIROZ JUNIOR, Teófilo de. Preconceito de Cor e a Mulata na literatura brasileira. São Paulo, Editora Ática, 1975.

REIS, João José. Rebelião Escrava no Brasil: a história do levante dos malês (1835). São Paulo, Companhia das Letras 2003.

. \& SILVA, Eduardo (orgs.). Negociação e Conflito: a resistência negra no Brasil escravista. São Paulo, Companhia das Letras, 1999.

REIS, Letícia Vidor de Souza. “A aquarela do Brasil: reflexões preliminares sobre a construção nacional do samba e da capoeira”. in: Cadernos de Campo, nº 3, São Paulo, 1993.

REVISTA USP - RACISMO I. São Paulo, CCS/USP, dezembro-janeiro-fevereiro, 2005-2006. ${ }^{\circ}$ 68.

RIO, João do. O Momento Literário. Rio de Janeiro, Fundação Biblioteca Nacional, 1907/1994.

ROMERO, Silvio. Contos Populares do Brasil. Belo Horizonte, Editora Itatiaia, 1885/1995. 
ROSA, Zita de Paula. O Tico Tico - Mito da Formação Sadia. São Paulo, Tese de Doutorado em História/FFLCH -USP, 1991.

SALLES, Vicente. “Luiz Demétrio Juvenal Tavares - Cronologia” In: Serões da Mãe Preta. Belém, Secretaria de Estado da Cultura/Fundação Cultural do Pará Tancredo Neves, 1890/1990.

SAHLINS, Marshall. Ilhas de História. Rio de Janeiro, Jorge Zahar, 1987/1999. . Cultura e Razão Prática. Rio de Janeiro, Jorge Zahar Editor, 2003.

SAYERS, Raymond. O negro na literatura brasileira. Rio de Janeiro, Edições O Cruzeiro, 1958.

SCHWARCZ, Lilia Moritz. Retrato em branco e negro. São Paulo, Companhia das Letras, 1987. . O espetáculo das raças. São Paulo, Companhia das Letras, 1993/2000.

. "Nem preto nem branco, muito pelo contrário: cor e raça na intimidade”. in: Lilia Moritz Schwarcz (org.). História da vida privada no Brasil - volume 4. São Paulo, Companhia das Letras, 1998/2006.

. As barbas do Imperador. São Paulo, Companhia das Letras, 2000.

. \& GARCIA, Lúcia (orgs.). Registros escravos: repertório das fontes oitocentistas pertencentes ao acervo da Biblioteca Nacional. Rio de Janeiro, Fundação Biblioteca Nacional, 2006.

SEVCENKO, Nicolau. Literatura como Missão: tensões sociais e criação cultural na Primeira República. São Paulo, Companhia das Letras, 1983/2003.

SLENES, Robert. "Senhores e Subalternos no oeste paulista” in: Luiz Felipe de Alencastro (org.). História da vida privada no Brasil vol. 2. São Paulo, Companhia das Letras. 1997/2002.

. Na Senzala, uma flor. Rio de Janeiro, Nova Fronteira, 1999.

TANNENBAUM, Frank. Slave and Citizen. Nova York, Vintage, 1947.

WAGNER, Roy. The Invention of Culture. Chicago, University of Chicago Press, 1981. 
Anexos 


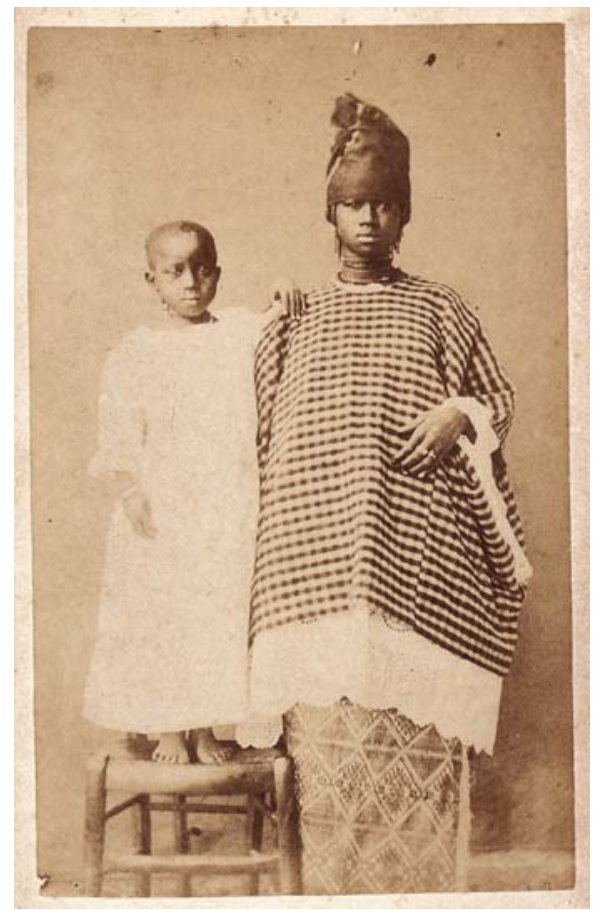

Retrato de Christiano Júnior, comentado por Manuela Carneiro da Cunha em: "Olhar escravo, ser escravo”. Paulo César de Azevedo e Maurício Lissovsky (Orgs.). Escravos brasileiros do século XIX na fotografia de Christiano Júnior. São Paulo, Ex-Libris, 1988. 


\section{Sumário}

\section{a) Imagem:}

Fotografia de Christiano Jr.

b) Fontes :

José de ALENCAR

Teatro Completo

Antonieta Borges ALVES

Brasil - Canção ............................................................................................... 5

Augusto dos ANJOS

Toda Poesia .......................................................................................................... 7

Murillo ARAUJO

A illuminação da vida

Manuel BANDEIRA

Libertinagem \& Estrela da Manhã .............................................................. 8

Olavo BILAC e Coelho NETTO

Contos Pátrios para crianças ......................................................................... 8

Raul BOPP

Urucungo

Humberto de CAMPOS

Histórias Maravilhosas - Contos Infantis .......................................................

Viriato CORREIA

Cazuza

Cyro COSTA

Terra Promettida …................................................................................................

Ribeiro COUTO

Poesias Reunidas

Aniete de Barros FAGUNDES

Revista da Folha

Luís JARDIM

O meu pequeno mundo

Jorge de LIMA

Novos Poemas

Poemas Negros 


\begin{tabular}{|c|c|}
\hline 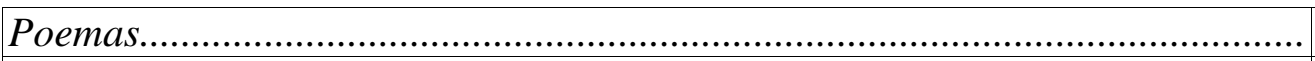 & 24 \\
\hline Monteiro I & \\
\hline 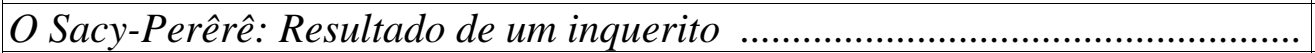 & 27 \\
\hline Mello MORAES FILHO & \\
\hline 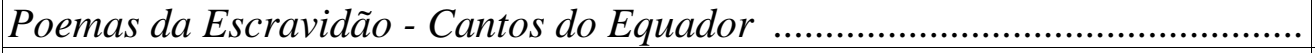 & 33 \\
\hline Ofélia FONTES e Narbal FONTES & \\
\hline Pindorama - leitura para os alunos dos cursos primário e ginasial & 38 \\
\hline Oswaldo ORICO & \\
\hline 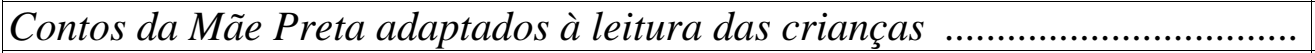 & 41 \\
\hline 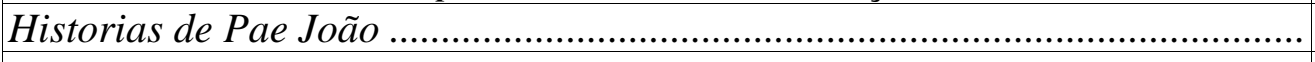 & 41 \\
\hline Cornélio PIRES & \\
\hline Quem conta um conto... E outros contos (coisas de outrora) & 48 \\
\hline 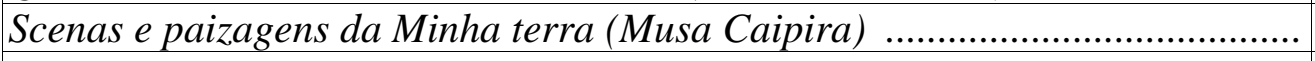 & 53 \\
\hline José Lins do $\mathrm{F}$ & \\
\hline 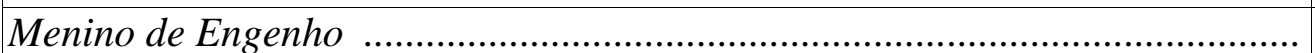 & 53 \\
\hline 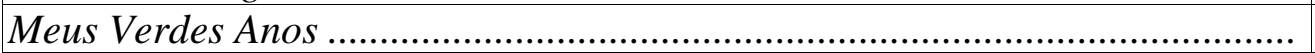 & 54 \\
\hline Histórias da Velha Totonia & 54 \\
\hline Cassial & \\
\hline 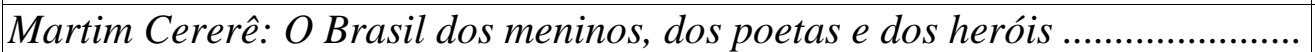 & 54 \\
\hline 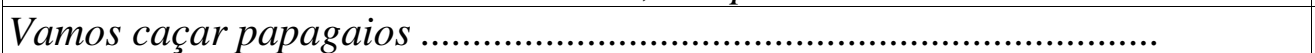 & 56 \\
\hline João do RIO & \\
\hline Entrevista com Coelho Netto ....... & 57 \\
\hline Entrevista com Silvio Romero & 58 \\
\hline Wilson W. $\mathrm{F}$ & \\
\hline 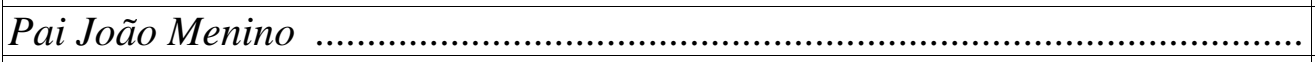 & 58 \\
\hline Luiz D & \\
\hline (n) & 60 \\
\hline 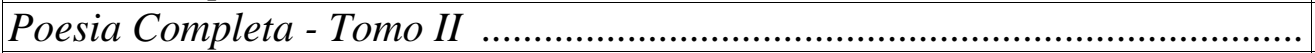 & 62 \\
\hline Hélio SEREJO & \\
\hline (1) & 64 \\
\hline étrio Juvenal TAVARES & \\
\hline Serões da Mãe Preta & 67 \\
\hline Maria Alves VELLOSO & \\
\hline As férias com a vovó & 70 \\
\hline A MÃI PRETA.. & 73 \\
\hline
\end{tabular}


José de Alencar."Mãe". In: Teatro Completo. Vol II. Rio de Janeiro: Fundação Nacional de Arte, 1859/sem data.

Joana - Mas iaiá é uma moça bonita!... E eu que sou sua mulata velha... desde que nhonhô Jorge nasceu que o sirvo, e nunca brigou comigo! Se ele não sabe ralhar... Olhe, iaiá! Todas as festas me dá um vestido bonito... E não dá mais porque é pobre!

Elisa - Foste tu que o criaste?

J oana - Foi, iaiá. Nunca mamou outro leite senão o meu...

Elisa - E por que ele não te chama - mamãe Joana?

Joana - Mamãe!... Não diga isso, iaiá!

Elisa - De que te espantas? Uma coisa tão natural?

J oana - Nhonhô não deve me chamar assim!... Eu sou escrava, e ele é meu senhor.

Elisa - Mas é teu filho de leite.

Joana - Meu filho morreu!

Elisa - Ah! Agora compreendo!... Esse nome de mãe te lembra a perda que sofreste!...

Perdoa, Joana. (p. 258)

Elisa - Eu te peço, Joana...

Joana - Nesse dia... Olhe, iaiá! Hei de pôr meu cabeção novo, como as mulatinhas da Bahia... Que pensa! Não faça pouco na sua escrava, iaiá! J oana também já foi moça... sabia riçar o pixaim e bater com o tacão da chinela na calçada; só - taco, taco, tataco! Oh! Hei de me lembrar do meu tempo... Se eu já estou chorando de contente!... E meu nhonhô como não há de ficar alegre! (p. 260)

Jorge - Digo sim! - D. Elisa, creio que minha mãe, a quem não conheci, não me teria mais amor do que esta segunda mãe, que me criou.

Joana - Hô gente, nhonhô! Isso são modos de tratar sua escrava. (p. 261)

Vicente - Olhe, Sra. Joana... Há muito que estou para lhe pedir uma coisa.

Joana - Não, mas é que... Sim... Bem vê que tenho hoje uma posição... E este modo de chamar a gente de Bilro...

Joana (rindo) - Ah! ah! ah!... Então porque és pedestre, ou meirinho... Não sei o quê!

Vicente - Menos isso!... Oficial de justiça!

Joana - Pois que seja... Oficial da justiça, ou da injustiça... Porque és isto, julgas que ficas desonrado se eu te chamar de Bilro?... Ora, não vejam só este meu senhor! Que figurão!... V. $\mathrm{S}^{\mathrm{a}}$. faz obséquio... Ou V. Exa.?... Queria ter a bondade... Por quem é... Sr. Vicente...

Vicente - Romão... Romão...

Joana - Sr. Vicente Romão. Queira desculpar!... sem mais aquela.

Vicente - Está zombando.

Joana - Hô!... Não é assim que deve tratá-lo?

Vicente - Toma o recado na escada... Eu por mim não me importava; mas falam.

Joana - Pois olha! Cá comigo está se ninando!... Eu te conheci assim tamaninho, já era rapariga, mucama de minha senhora moça, que Deus tem, e foi sempre Bilro para lá, tia Joana para cá. Se quiseres há de ser o mesmo... senão, passar bem. Ninguém há de morrer por isso.

Vicente - Mas, J oana...

Joana - Tia J oana! (p. 269)

Joana - Como me lembra!... Eu tinha dezessete anos, e tu eras um pirralho de oito. Vinhas bulir com ele no meu colo; e como eras muito travessão, nós te começamos a chamar de Bilro. Nunca estavas quieto!

[...] 
Vicente - Lá isso eu sempre disse... Nunca houve mulatinha que desse mais a respeito do que tia Joana. Pois em casa punham a boca em todos; mas dela não tinham que mexericar.

[...]

Vicente - É mesmo, tia Joana. Bom tempo! Sr. Doutor só fazia ralhar. Tirante disso, era bom amo. (p. 270)

Joana - O ciganinho, pajem de meu senhor... (p. 271)

Dr. Lima - Como vai teu filho?... Já está um homem?

J oana - E há de durar sempre! Meu senhor me prometeu.

Dr. Lima - Prometi.

Joana - Meu senhor jurou!

Dr. Lima - É verdade! Mas julgava que na minha ausência tudo se havia de se revelar, Joana - Ele não sabe nada, e eu peço todos os dias a Deus que não the deixe nem suspeitar.

Dr. Lima - Assim tu ainda passa por sua escrava?

J oana - Não passo, não! Sou escrava dele.

Dr Lima - Mas Joana! Isto não é possível!

Joana - Meu senhor... Eu já lhe disse!... E não cuide que por ter esta cor não hei de cumprir... No dia em que ele souber que eu sou... que eu sou... Nesse dia Joana vai rezar ao céu por seu nhonhô.

Dr. Lima - E por que razão hás de fazer uma tal loucura?

Joana - Por quê?... Desde que nasceu ainda está para ser a primeira vez que se zangue comigo. E Vm. Quer que se envergonhe... Que me aborreça talvez!... Meu Deus! Matai-me antes que eu veja essa desgraça!

Dr. Lima - És tu a culpada?

Joana - Não sei, meu senhor, não sei. Às vezes penso... Quando fazem vinte e um anos e senti o primeiro movimento dele... de meu...

Dr. Lima - De teu filho. Fala! Que receio é esse?... Estamos sós.

Joana - Vm. Não sabe que medo tenho de dizer este nome!... Até à noite quando rezo por ele baixinho... não me atrevo... Ele pode ouvir... Eu posso me acostumar...

Dr. Lima - Mas dizias?

Joana - Ah! Quando senti o primeiro movimento que ele fez no meu seio, tive uma alegria grande, como nunca pensei que uma escrava pudesse ter. Depois uma dor que só tornarei a ter se ele souber. Pois meu filho havia de ser escravo como eu? Eu havia de lhe dar a vida para que um dia quisesse mal à sua mãe? Deu-me vontade de morrer para que ele não nascesse... Mas isso era possível? Não, J oana devia viver!

Dr. Lima - Foi então que Soares te comprou...

Joana - Ele me queria tanto bem! Deu por mim tudo quanto tinha... Dois contos de réis! Eu fui para a sua casa. Aí meu nhonhô nasceu, e foi logo batizado como filho dele, sem que ninguém soubesse quem era a sua mãe.

Dr. Lima - Desgraçadamente morreu poucos dias depois... Se eu soubesse então!... Joana - Mas meu senhor não sabia nada. Fui eu que Ihe confessei...

Dr. Lima - Porque já tinha suspeitado...

Joana - E por isso só. Vm. era capaz de afirmar? Não! Quem Ihe contou fui eu, com a condição de não dizer nunca!...

Dr. Lima - Pois bem, Joana! Não direi uma palavra. Continuarás a ser escrava de teu filho. Será para ele a dor mais cruel quando souber...

Joana - Nunca!... Quem vai Ihe dizer?... Além de Vm. e de mim, só Deus sabe este segredo. Enquanto meu senhor estava fora eu vivia descansada...

Dr. Lima - E tinhas razão... Presente, vendo-te ao lado de Jorge, não respondo por mim. 
Joana - Meu Senhor, Vm, teve sua mãe... Lembre-se que dor a pobre havia de sentir se seu filho tivesse vergonha dela!... Não o faça desgraçado! E por causa de quem?... De mim que morreria por ele.

Dr. Lima - Bem; prometo-Ihe que hei de ter coragem! Virei raras vezes aqui. Evitarei o mais que puder... com receio de me trair.

J oana - É melhor. Até Vm, se habituar.

Dr. Lima - Nunca me habituarei!... Tu não sabes como eu te admiro, Joana; e como dói-me no coração ver esse martírio sublime a que te condenas.

Joana - Eu vivo tão feliz, meu senhor!

Dr. Lima - Mas que necessidade tinhas de ser escrava ainda? Não podias estar forra?

Joana - Eu, meu senhor?... Como?

Dr. Lima - Com o dinheiro que tiravas do teu trabalho, e gastavas na educação de teu filho.

Joana - Nunca pensei nisso, meu senhor!... Demais, forra, podiam-me deitar fora de casa, e eu não estaria mais junto dele. A escrava não se despede.

Dr. Lima - Mas... Estremeço só com essa idéia!

Joana - Qual, meu senhor?

Dr. Lima - Supõe que... te vendiam.

Joana - Joana morreria; porém ao menos deixaria a ele aquilo que custasse... sempre era alguma coisa... Para um moço pobre!

Dr. Lima - E eu hei de estar condenado a ouvir Jorge agradecer-me a sua educação que ele deve unicamente a ti; a chamar-me seu segundo pai, ignorando que sua...

Joana - Mais baixo!... Não se zangue, meu senhor!

Dr. Lima - Sabes que mais! Vou-me embora. Voltarei logo para abraçar Jorge, e não pisarei mais aqui. É uma tortura!

Joana - Adeus, meu senhor! Não se agaste comigo.

Dr. Lima - Não. Quem sabe se tu não tens razão!

Joana - Deus dê muita felicidade ao meu senhor. Dr. Lima. (abre a porta.) (p. 272274)

Jorge - Faço também algumas traduções que deixam à vezes um extraordinário. Joana por seu lado ganha...

Joana - Quase nada nhonhô! Já estou velha. Não coso mais de noite.

Jorge - Nem eu quero. Foi de passares as noites sobre costura que ias perdendo a vista.

Dr. Lima - Faz bem em tratá-la com amizade, Jorge. É uma boa...

Joana - Sou uma escrava como as outras.

Jorge - És uma amiga como poucas se encontram.

Joana - Ora, nhonhô!...

$[\ldots]$

Jorge - Olhe, doutor! Estou no meio de minha família. Meu segundo pai, minha segunda mãe! Não conheci os outros.

[...]

Jorge - Toma, Joana. Eu escrevia-a esta manhã lembrando-me de minha mãe.

Dr. Lima - Muito bem, Jorge. Deus o inspirou!

Joana - Mas o quê... Que papel é este, nhonhô?

Dr. Lima - É a tua carta de liberdade, Joana!

Joana - Não quero! Não preciso!

Jorge - Não é tua carta de liberdade, não, minha boa Joana; porque eu nunca te considerei minha escrava. É apenas um título para que não te envergonhes mais nunca da afeição que tens.

Joana - Mas eu não deixarei a meu nhonhô?

Jorge - A menos que tu não exijas. 
$[\ldots]$

Jorge - Há muito tempo, doutor, que tencionava realizar este pensamento. Mas tinha tomado algum dinheiro com hipoteca...

Dr. Lima - Com hipoteca!... Sobre J oana?

Joana - Que mal fazia?

Jorge - Conheço que fui imprudente, mas a necessidade urgia.

Dr. Lima - Não o censuro, Jorge! O senhor não sabia...

Jorge - O que, doutor?

Dr. Lima - Não sabia... Quanto os empréstimos são perigos!...

Jorge - Felizmente já não sou devedor... Nem ao homem que me emprestou... Nem à minha consciência que me ordenava desse a Joana essa pequena prova de estima que Ihe tenho. Resta-me ainda uma dívida... Dívida de amizade e gratidão que nunca poderei pagar.

Dr. Lima - A ela!... Por certo que nunca!

Joana - A meu senhor!... A mim não. (Batem) (p. 275-276)

Antonieta Borges Alves. Brasil - Canção. São Paulo, Escolas Profissionais Salesianas, 1954.

\section{RITMO AFRICANO}

Pai João envelheceu a plantar cana doce;

Pai João envelheceu a plantar o café;

cana e café gostaram não foi só da terra estupenda,

foi também do carinho das mãos do Pai João!

- Quem não tem mão boa,

planta, não pega...

planta, não brota...

planta, não adianta!...

Vai cana para a moenda,

vai café para torrar;

vai açúcar para longe,

vai café - riqueza vem!

E o negro luta, o negro sua, o negro canta, canta baixinho com mêdo do Sinhô...

- Cantiga de negro é banzo!

Cantiga de negro é pranto!

Porque cantiga de negro, são cadências de acalanto que adormecem muita dor!

Pai J oão ensinou sua cantiga aos cafeeiros e aos canaviais!

Quase perto da morte Pai João sonhava ainda com as canas de açúcar, com os pés de café!... 
Hoje ao vento que passa, os lindos cafeeiros

e os verdes canaviais repetem a surdina

dos tempos do Pai João:

E o café

$$
\text { Xangô... Xan-go-ô... }
$$

e o açúcar,

guardam eternamente na côr e na doçura,

a negrura da pele e a doçura da alma,

a lembrança mais viva do cativo africano! (p. 44 e 45)

MAMÃE PRETA

Dorme, nenê,

Dorme, nenê,

que o bicho vem pegá...

dorme nenê...

.... E o nenê da sinhá

dormiu no colo da negra velha.

Agora a mamãe-preta vai dormir?...

- Que! não vai não!

Mãe-preta vai engomar,

vai torrar café,

vai fritar torresmo,

vai fazer sabão...

Mãe-preta não dorme, não!

De repente sinhozinho

faz berreiro lá no quarto:

Ela pega sinhozinho,

põe-se a cantar outra vez...

- Que é isso Mamãe-preta? Você não descansa?

Você vai trabalhar com...

com êsse chorão nos braços?...

- Quá o que! a lã não pesa pro carneiro...

- Verdade! A lã não pesa para o carneiro!...

E mamãe-preta, de tão boa e mansa,

é realmente uma ovelhinha branca,

que afagou o sinhozinho,

que embalou o Brasil! (p. 46) 
Augusto dos Anjos. "Eu" in: Toda Poesia. Rio de Janeiro, Paz e Terra, 1912/1978.

RICORDANZA DELLA MIA GIOVENTU

A minha ama-de-leite Guilhermina

Furtava as moedas que o Doutor me dava.

Sinhá-Mocinha, minha Mãe, ralhava...

Via naquilo a minha própria ruína!

Minha ama, então, hipócrita, afetava

Susceptibilidades de menina:

'- Não, não fora ela!'- E maldizia a sina,

Que ela absolutamente não furtava.

Vejo, entretanto, agora, em minha cama, Que a mim somente cabe o furto feito...

Tu só furtaste a moeda, o ouro que brilha...

Furtaste a moeda só, mas eu, minha ama, Eu furtei mais, porque furtei o peito

Que dava leite para tua filha.

Murillo Araujo. A illuminação da vida. Rio de Janeiro, sem editora, 1927. s/p. Poemas compostos entre 1922 e 1927.

MI NHA MÃE PRETA

Minha mãe-preta já pequena

de velhice -

é hora do sono: escute a minha cantilena

como escutei as suas já

na meninice.

Quando com o vulto negro, com a carapinha alvejada,

você erguia uma luz por sôbre nosso berço

e nossos olhos riam para vê-la -

parecia - Mãe-Preta - a noite enluarada

que nos trouxe a graça de uma estrêla!

Quando nos carregava nos seus ombros...

ou nos furtava os doces em segrêdo...

ou nos acalentava nos assombros do nosso mêdo -

oh Mãe-Preta, oh luz mansa

era o seu coração nosso melhor brinquedo,

o ingênuo coração que vivia e morria

com inocência de criança.

Quando a Noite na sua meia-língua

engrolava as histórias

com aquela voz cansada como o sono...

você - mísera enfêrma das senzalas - 
você - dor e abandono -

tinha a ilusão e a fôrça de falar-nos só das glórias,

dos palácios de luz, dos príncipes de galas

e das princesas de vestido côr do dia...

você mesma era como a moura encantada,

uma figura de seus contos animada

que viesse e nos levasse aos reinos da Harmonia.

Oh Mãe-Preta, Mãe-Preta -

Deus quis dar-Ihe essa côr entenebrada

para esconder a sua dor calada

sem nos fazer chorar pela sua ânsia!

Deus quis dar-lhe essa côr de silhueta

Para torná-la mais indefinida

Mais irreal de sonho, mais perdida

Nos longes da memória e da distância...

Deus quis você bem símplice - Mãe-Preta

Deus quis você bem docemente sombra

Para que fôsse a sombra azul da Infância!

Manuel Bandeira. "Libertinagem" in: Libertinagem \& Estrela da Manhã. Rio de Janeiro, Editora Nova Fronteira, 1930/2000.

IRENE NO CÉU

I rene preta

Irene boa

Irene sempre de bom humor

I magino Irene entrando no céu:

- Licença, meu branco!

E São Pedro bonachão:

- Entra, Irene. Você não precisa pedir licença.

Olavo Bilac e Coelho Neto. Contos Pátrios para crianças. Rio de Janeiro, Francisco Alves \& Cia, 1894/1918, $16^{\text {a }}$ edição.

MÃE MARIA

É ainda esta, no fim de minha longa vida, tão cheia de alegrias e tristezas, a recordação mais funda que guardo dentro da alma.

Fechando os olhos, para mais claramente evocar a memória dos dias da minha infancia, vejo logo, nitidamente desenhada pela minha saudade, a doce figura da velha Mãe Maria. Tão velha!... Quando nasci, já o seu cabello encarapinhado embranquecia. Ainda viveo comigo uns treze annos. E nunca ninguem me soube dizer onde morreo, e onde foi dormir o ultimo somno o seu corpo de velha escrava, alquebrado por quasi um século de captiveiro e de trabalho.

Comprar e vender escravo era, naquelle tempo, uma cousa natural. Ninguem perguntava a um negro comprado o seu passado, como ninguem procurava saber de 
onde vinha a carne com que se alimentava ou a fazenda com que se vestia. De onde vinha a velha Maria, quando, logo depois de meu nascimento, meu pae a comprou? Sei apenas que era africana; e tinha talvez um passado terrivel: porque, quando a interrogavam a esse respeito, um grande terror lhe dilatava os olhos, e as suas negras mãos reluzentes e callejadas eram sacudidas de um tremor compulsivo.

Comnosco, a sua vida foi quasi feliz. Na cidade, o captveiro era infinitamente mais brando do que na roça. Aqui, se havia o trabalho sem tréguas, não havia, ao menos, o chicote do feitor. Lá fóra, sim! lá fóra, era a labuta esfalfante do café, os dias terriveis sob o sol implacável, a comida pouco e o castigo muito. Maria, quando eu às vezes lhe perguntava o que era a roça, ficava calada, olhando o chão, como se estivesse revendo com horror o tormento d'essa vida antiga. Um dia despio a meio a camisa de algodão grosso, e mostrou-me as costas e o peito. A pelle preta estava de espaço a espaço cortada de largos vergões, cicatrizes, signaes de queimaduras. Eu, com os meus innocentes olhos de seis annos, olhava aquillo sem compreender. "Como foi isso, mãe Maria?». «Maldades dos homens, Sinhôsinho, maldades dos homens...». Certa noite, como ella me contasse uma historia em que se falava de creanças roubadas aos paes, perguntei: «Você nunca teve filho, Mãe Maria?» A pobre negra limpou uma lagrima, e não respondeo: mudou de conversa, e continuou, com sua meia lingua atrapalhada, a historia - uma d'essas compridas historias da roça, em que ha saciperêrês e caipóras, almas do outro mundo e anjos do céo. E eu olhava-a, com uma secreta mágoa... Não que comprehendesse bem aquillo: mas a minha intelligencia de creança já adivinhava uma parte d'aquella dolorosa vida de captiva.

Como ainda me lembro d'essas noite!... Era na sala de jantar, que tinha uma grande varanda, deitando para o quintal. Estou ainda vendo o velho sofá de madeira negra em que meu pae dormia a sésta, a longa taboa de engommar em que a mucamas passavam a ferro a roupa branca, e perto da meza em que ardia o grande lampião de azeite, minha mãe immovel e pallida, na sua feia e enorme cadeira de paralytica.

Moça ainda, ficara ella assim, logo depois de ter eu vindo ao mundo. Como a perdi muito cedo não me lembro bem d'ella: apenas sei que era bonita e que não falava nunca. Olhava para mim, para meu pae, para as escravas, com um olhar apagado, de louca resignada e mansa.

Assim, a velha Maria foi a minha verdadeira mãe. Havia ainda em casa uma senhora edosa, prima de meu pae, que era quem dirigia tudo. Essa, porém, apenas tinha tempo para governar as escravas, fazer doces e cuidar das costuras e das roupas engommadas. - Boa mãe Maria! Era ella quem me lavava, quem me vestia, que me aturava... Quando eu não queria obedecer, procurava fingir se zangada, e ameaçavame: «Nhô Amancio! Nhô Amancio!» E acalmava-me, por fim, promettendo-me uma nova historia. Sentava-se no chão cruzava as pernas, e começava. Ouvia-se apenas na sala o resonar de meu pae que dormia a sésta, o pigarro da velha prima que cosia, o ruído que faziam os ferros de engommar sobre as táboas, e a voz arrastada de mãe Maria, falando de saciperêrês, de caipóras, de almas do outro mundo e de anjos do Senhor.

Todo aquelle enredo fantástico, em que passavam bruxas cavalgando cabos de vassouras, principes que roubavam princezas, archanjos que desciam do céo para curar as feridas dos escravos no tronco, negras aleijadas, que invocavam o diabo, à meia noite, no meio do matto, e eram afinal arrebatadas por elle, numa nuvem de fogo e enxofre - tudo aquillo se atropellava na minha cabeça, cançando-me, dando-me arrepios e vertigens de medo.

D'ahi a meia hora, pesavam-me as palpebras. Aos meus ouvidos, a voz de Maria chegava cada vez mais fraca: até que quase sumida de todo, parecia vir de longe, de muito longe, vaga e indistincta como um echo. Eu deixava caír a cabeça sobre o seu collo, e dormia. E era ella quem, carinhosamente, me levava para a cama, 
era ella quem me despia e, obrigando-me a ficar de joelhos, tonto de somno, me fazia repetir o Padre Nosso, estropiado pela sua língua de africana.

Quando tive de ir para o collegio, - um internato serio de onde os alumnos só saíam uma vez por anno, - chorei muito tempo, abraçando a Mãe Maria, agarrado à sua grosseira saia de riscado azul. Ella chorava também, chamando-me seu filho, beijando-me, consolando-me:

- Vae, Nhô Amâncio! vae, meu filho! vae p'ra ser homem! vae, Nhô Amâncio! a sua negra velha fica resando a Nosso Senhor! a velha fica resando!

Pela mão de meu pae, fui pela rua soluçando, soluçando.

Oh! os primeiros dias de internato! Que casa! As salas, muito altas e muito claras, tinham um silencio que dava medo. Entre as bancas de estudo; o padre Francisco passeava, batendo com força os tacões dos sapatos, fungando pitadas de rapé. Eu, com a morte na alma, lembrava-me da casa, lembrava-me da varanda que dava para o quintal, da minha mãe immovel na sua enorme e feia cadeira de paralytica, da velha prima que costurava e da mãe Maria... de mãe Maria! e das suas mãos callejadas e reluzentes! e do seu cabello encarapinhado! e da sua voz! e das suas historias! E as letras do livro iam se confundindo e dansando, vistas atravez das lagrimas que me embaciavam os olhos.

Mas, passou a primeira semana, passou a primeiro mez, passou o primeiro trimestre. Criei amisade aos companheiros. E a minha saudade foi diminuindo, diminuindo, diminuindo...

Quando o primeiro semestre findou, já mãe Maria, e a sua face, e a sua voz, e as suas historias, me appareciam indistinctamente, como no fundo de um passado remoto. À noite, quando me deitava, depois do exercício violento da cabra-cega e da barra, o somno já não me deixava pensar naquella que ficara resando a Nosso Senhor por Nhô Amâncio. Nhô Amâncio só se lembrou de mãe Maria quando as ferias chegaram...

«Ah! Nhô Amâncio! - dizia a preta chorando, de joelhos, beijando-me as mãos - como Nhô Amâncio está crescido e bonito!»

Um anno de collegio bastara para me transformar. E, agora, eu apparecia à velha ama-secca, como um novo Sinhô-moço - um Sinhô-moço que tinha 11 anos, que já sabia ler e escrever, que já se julgava um homem, e que às histórias, atrapalhadas e tolas de mãe Maria preferia a malha e a gymnastica.

A vida da casa era a mesma. Apenas mãe Maria, não tendo agora Sinhô-moço para crear, passara a tratar da lavagem da roupa.

E era no quintal que estava agora quasi sempre, de saia levantada, patinhando a agua da barréla, indo de coradouro a coradouro, - um pouco mais velha, um pouco mais trôpega, mas ainda robusta.

Foi durante essas ferias que se deo o caso, cuja recordação ainda hoje, no fim da minha longa vida, tão cheia de alegrias e de tristezas, é a mais viva das que guardo dentro da alma.

Uma tarde, mãe Maria lavava roupa no quintal. Desci. Ao fundo, ficavam os cercados das galinhas. Comecei a atirar-Ihes pedras. Mãe Maria protestou logo: «Nhô Amâncio! Nhô Amâncio! que maldade menino! deixa os bichos, Nhô Amancio» Eu ria, e continuava.

Entre mim e os cercados do gallinheiro ficavam os coradouros. As pedras passavam sobre a cabeça da velha.

- «Nhô Amâncio! Nhô Amâncio! Deus castiga, Nhô Amâncio! Nhô Amâncio» repetia a preta, mas sem gritar, receiando que meu pae a ouvisse. E eu ria, e continuava. Correo então para mim... Eu ria. E as pedras passavam por ella, rentes algumas, na direção dos cercados. 
Não sei como foi... Via-a cambalear e cair, levando as mãos à cabeça, de onde o sangue corria aos borbotões. Senti no coração uma pancada secca, dolorosa. Uma nuvem de pranto me cresceo nos olhos. Corri para a velha, com a garganta suffocada de soluços.

Uma pedrada lhe quebrara a cabeça e o sangue ensopava a sua carapinha dura, já quasi toda branca. Principiei a gritar, allucinadamente. E ella, tremula, desfalecida, apertando a ferida com a mão manchada de vermelho, murmurava:

«Não grita, Nhô Amâncio. Não grita! Não foi nada! Não grita, que Sinhô ouve!»

Mas eu gritava. Todo o antigo affécto esquecido renascia alli, diante da minha velha mãe Maria, toda banhada em sangue, ferida por mim. Toda a casa acudira os meus gritos. Vi junto de nós meu pae, a prima, as escravas. Então tive medo do castigo.

Mas a velha já tinha um sorriso nos lábios. E, olhando meu pae, que indagava a causa d'aquillo, dizia: «Não foi nada, Sinhô, não foi nada! A negra velha escorregou no sabão, e quebrou a cabeça nas pedras. Mas Nhô Amâncio acudiu logo. Não foi nada Sinhô, não foi nada!»

Quando, pensada a ferida, eu, a sós com ella, a vi salva e repousada, - caí nos seus braços pedindo-lhe perdão, cobrindo de beijos aquella face que me parecia tão bella, tão clara, tão iluminada, como a face de um daqueles anjos do Senhor, de que ella me falava nas suas compridas historias da roça. E ella, chorando tambem:

«Que é isso, Nhô Amâncio? Que foi que mãe Maria fez?... tinha que ver que Nhô Amâncio fosse apanhar uma sova por causa do cangalho de uma negra velha!...»

D'ahi a um anno, quando de novo voltei ao collegio, ainda, abracei mãe Maria. Vi-a e abracei-a ainda, pelo Natal dois annos seguidos. Depois... morto meu pae, morta minha Mãe, vendido todos os escravos da casa, - nunca tive quem me disesse onde foi dormir o seu ultimo somno a minha velha mãe Maria, alquebrada por quasi um século de captiveiro e trabalho. (p. 15-30)

Raul Bopp. Urucungo. Rio de Janeiro, Ariel, 1932.

MÃE-PRETA

- Mãe-preta conte uma história

- Então feche os olhos filhinho:

Longe muito longe

era uma vez o rio Congo...

Por tôda parte o mato grande

Muito sol batia o chão

De noite

chegavam os elefantes

Então o barulho do mato crescia

Quando o rio ficava brabo

inchava

Brigava com as árvores

Carregava com tudo águas abaixo

até chegar na bôca do mar 
Depois...

Os olhos da preta pararam

Acordaram-se as vozes do sangue

glu-glus de água engasgada

naquele dia do nunca-mais

Era uma praia vazia

com riscos brancos de areia

e batelões carregando escravos

Começou então

uma noite muito comprida

Era um mar que não acabava mais

...depois...

- Ué mãezinha

porque você não conta o resto da história? (p. 95-96)

\section{CASOS DA NEGRA VELHA}

A floresta inchou

Uma árvore disse:

- Quero virar elefante,

E saiu correndo no meio do mato

Aratabá-becum

Aquela noite foi muito comprida

Por isso é que os homens saíram pretos (p. 97)

Humberto de Campos. Histórias Maravilhosas - Contos Infantis. Biblioteca Infantil d'o tico-tico. Rio de Janeiro, S. A. “O Malho” Gráfica Editora, s. d.

\section{O BODE DO PAI JOÃO}

Pai João, preto velho, estava com oitenta anos, e morava num rancho que êle mesmo fizera com folhas de palmeira, quando teve um sonho. Sonhou que Nosso Senhor descera do céu, e ele lhe aparecera dizendo:

- João, a tua fortuna está no teu bode. Mata o teu bode, vai vender a carne na cidade, e ficarás rico!

Tudo que Pai João possuia era um bode; mas o bode estava tão velho, tão magro, e tão pelado, que ninguém lhe compraria a carne, nem daria um tostão pelo couro. Mas o negro velho não se importou com isso. Quando amanheceu, matou o velho bode magricela, pôs a carne em um cesto, e encaminhou-se para o mercado da cidade, a fim de vendê-la. Mas ninguém comprava. A carne do bode de Pai João catingava tanto que tôda gente ao passar por perto do cesto fugia, tapando o nariz.

O dia já ia alto e Pai João não tinha vendido nem meio quilo de bode. E foi quando êle notou que havia uma porção de cachorros em roda do cesto, atraídos pelo cheiro da carne, que principiava a apodrecer. 
- Cachorros da cidade, vocês querem comprar a carne de bode de Pai João? perguntou o negro velho.

- Au! au!... Au! au! au!... - ladraram os cachorros, ao ver que o preto velho se estava dirigindo a êles.

- Querem, não? - tornou o negro velho - Mas vocês têm dinheiro pra comprar carne do bode de Pai J oão?

- Au! au! au!... Au!... au!... au!... - tornaram os cachorros.

- Não tem, não?... Querem comprar fiado; não é?

- Au! au! au!...

- Mas, vocês pagam no domingo que vem... Não pagam?

- Au! au! au!... Au!

- Pois, bem; eu vendo. Mas não vão me enganar!

E atirando pedaços de carne aos cachorros:

- Toma!... toma!... toma!... toma!... Domingo, negro velho vem buscar dinheiro dêle... Olhem lá!

Esvasiando (sic) o cesto, Pai João tomou o rumo de seu rancho. No domingo seguinte voltou. Ao vê-lo, os cães, supondo que êle ainda lhes trouxesse carne, correram a cercá-lo.

- Cadê meu dinheiro? - perguntou o negro velho.

- Au! au!... - ladraram os cães.

- Dinheiro de quê? Dinheiro da carne do bode... Então vocês não se lembram?

- Au! au! au!...

- Não pagam?... Não pagam, uma história! Quem não pagar vai prêso!

- Au!... au!... au!...

- Esperem aí!

E Pai J oão passou a corda em três cachorros magros que conseguiu segurar, e que conduziu arrastados, para o seu rancho.

Ali chegando, amarrou-os no tronco de uma grande mangueira que havia perto dizendo-Ihes:

- Agora, ficam aí até pagar o bode do negro velho... Quem come, paga; quem come e não paga vai prêso! Podem chorar, podem gritar; não solto!

Durante o dia todo os cachorros ladraram de raiva. Durante a noite, ganiram de fome e sêde. Na outra noite, puseram-se a uivar, e a cavar o chão com a unhas, furiosamente. E tanto cavaram a terra, que desenterraram uma bacia cheia de moedas de ouro que ali se achava escondida há muitos anos, e de que ninguém tinha notícia.

Quando amanheceu, pai Jão foi ver os cachorros. Encontrando em tôrno dêles uma porção de moedas, riu, com a sua bôca mole de preto velho; pagaram?

- Não disse que vocês pagavam a carne do bode de Pai J oão? Pagaram ou não

Juntou as moedas. Contou-as. Desatou os cachorros:

- Podem ir... Não tem trôco, não...

Um cachorro ainda parou ao longe, e ladrou:

- Au! au!...

- Recibo? Não dou recibo, não... Se quiser recibo, traga o sêlo!

E Pai João: (sic)

rico.

- Foi assim que, com o seu sonho, e a carne de seu bode velho, Pai J oão ficou

Viriato Correia. Cazuza. São Paulo, Companhia Editora Nacional, 1938/1979 27ª edição.

\section{A CONTADEIRA DE HISTÓRIAS}

Vovó Candinha é outra figura que nunca se apagou de minha recordação. 
Não havia, realmente, mulher que tivesse maior prestígio para as crianças de minha idade. Para nós, era um ser à parte, quase sobrenatural, que se não confundia com as outras criaturas. É que ninguém no mundo contava melhor histórias de fadas do que ela.

Devia ter seus setenta anos: rija, gorda, preta, bem preta e a cabeça branca como algodão em pasta.

Morava distante. Vinha ao povoado, de quando em quando, visitar a Luzia, sua filha caçula, casada com o Lourenço Sapateiro.

E quando corria a notícia de que ela ia chegar, a meninada se assanhava como se ficasse à espera de uma festa. Não saíamos da porta da Luzia, perguntando insistentemente:

- Quando ela chega?

- Traz muitas histórias bonitas?

- Traz muitas novas?

Era pela manhã que vovó Candinha costumava chegar. O dia nem sempre havia acabado de nascer e já a pequenada estava à beira do rio para recebe-la. Mal ia saltando da canoa, nós corríamos a abraça-la com tanta afoiteza e tanta efusão que havia perigo de Ihe rasgarmos o vestido rodado, de chita ramalhuda.

- Quantas histórias a vovó traz? perguntávamos.

- Um bandão delas, respondia a velha.

De dia não conseguíamos que ela nos contasse história nenhuma.

- Quem conta histórias de dia, dizia, negando-se, cria rabo como macaco.

Mal a noite começava a cair, a meninada caminhava para a casa da Luzia, como se dirigisse para um teatro. Após o jantar, vovó Candinha vinha então sentar-se ao batente da porta que dava para o terreiro. cachimbo.

Enquanto se esperavam os retardatários, ela fumava pachorrentamente o seu

Sentávamo-nos em derredor, caladinhos, de ouvido atento, como não fora tão atento o nosso ouvido na escola.

Ela começava:

- Era uma vez uma princesa muito orgulhosa, que fez grande má-criação à fada sua madrinha...

Acendiam-se os nossos olhos, batiam emocionados os nossos corações...

Não sei se é impressão de meninice, mas a verdade é que até hoje, não encontrei ninguém que tivesse mais jeito para contar histórias infantis.

$\mathrm{Na}$ sua boca, as coisas simples e as coisas insignificantes tomavam um tom de grandeza que nos arrebatava; tudo era surpresa e maravilha que nos entrava de um jacto na compreensão e no entusiasmo.

E não sei onde ela ia buscar tanta coisa bonita. Ora eram princesas formosas, aprisionadas em palácios de coral, erguidos no fundo do oceano ou das florestas; ora reis apaixonados que abandonavam o trono para procurar pelo mundo a mulher amada, que as fadas invejosas tinham transformado em coruja ou rã.

Não perdíamos uma só das suas palavras, um só dos seus gestos.

Ela ia contando, contando... Os nossos olhinhos nem piscavam...

A lua, como se fosse uma princesa encantada, ia vagando pelo céu, toda vestida de branco, a mandar para a terra a suavidade dos seus alvos véus de virgem.

Lá pelas tantas, um de nós encostava a cabeça no companheiro mais próximo e fechava os olhos cansados. Depois outro; depois outro.

E quando vovó Candinha acabava a história, todos nós dormíamos uns encostados aos outros, a sonhar com os palácios do fundo do mar, com as fadas e as princesas maravilhosas. (p. $24-26$ ) 
Cyro Costa. Terra Promettida. Rio de Janeiro, José Olympio Editora, 1938. (Compilação póstuma de sua obra publicada nos jornais entre 1900 e 1937).

\section{PAE J OÃO}

Do taquaral á sombra, em solitária furna,

Para onde, com tristeza, o olhar curioso, alongo,

Sonha o negro, talvez, na solidão nocturna,

Com os limpidos areaes das solidões do Congo...

Ouve-Ihe a noite a voz nostalgica e soturna,

Num suspiro de amor, num murmurejo longo...

E o rouco, surdo som, zumbindo na cafurna,

É urucungo a gemer na cadencia do jongo...

Bendito sejas tu, a quem, certo, devemos

A grandeza real de tudo quanto temos!

Sonha em paz! Sê feliz! E que fique de joelhos,

Sob o fulgido ceo, a relembrar, magoado,

Que fructos do café são glóbulos vermelhos

Do sangue que escorreu do negro escravizado! (p. 159-160)

\section{MÃE PRETA}

Lugubre, acaçapada, espiando no ermo, á beira

Do açude da fazenda, a lua côr de opala,

Com sussurros de reza ou rumores de feira,

Via-se, num quadrado, a sordida senzala...

Sobre um velho giráo furado de uma esteira,

Eil-a, embalando ao collo - e com que amor na fala! -

O <sinhôzinho branco>, a quem se dava, inteira,

Até que, adulto, fosse, um dia, vergastal-a!

Soffreu como ninguém! Com fervor nunca visto,

Persignava-se ao ver ceos azues e montanhas:

<Louvado seja Deus Nosso Sinhô - Suns Christo!>

Na escravidão do amor, a criar filhos alheios,

Rasgou, qual pelicano, as maternaes entranhas,

E deu, á Pátria livre, em holocausto, os seios! (p. 161-162) 
Ribeiro Couto. "Noroeste e outros poemas do Brasil". in: Poesias Reunidas. Rio de Janeiro, Livraria José Olympio, 1932/1960. (Poemas escritos entre 1926-1928).

\section{SANTOS VII}

Tinha sido mulata muito bonita

No tempo da escravidão.

Sinha Maria do Bôlo vendia doces

E andava arrastada, com reumatismo.

Levava tempo para chegar.

Sinha Maria do Bôlo contava histórias,

Casos de família, saudades de outro tempo.

- Sinha Maria do Bôlo, qual foi a barbaridade

Da sua sinhá, no tempo da escravidão?

- Mandô rapá minha cabeça.

... Tinha sido mulata muito bonita no tempo da escravidão. (p. 257)

Aniete de Barros Fagundes. Relações inter-raciais. Revista da Folha. São Paulo: Folha de São Paulo. Seção Plural/Black. Edição Especial. 24/12/2000.

“Em 1980, precisei contratar uma babá para meu filho de 2 anos, pois, trabalhando fora em horário integral, lamentavelmente, eu não podia cuidar dele. Foi difícil encontrar uma pessoa que ele não estranhasse.

Pela agência de empregos veio a loura do Rio Grande do Sul. O menino abriu um choro tão logo a viu. Não servia. Veio outra, também branca, muito experiente, mas que o menino não suportava a presença. Assim foi: dentre cinco candidatas, nenhuma se ajustava.

Finalmente, a empregada de uma amiga apresentou-me a Lucia. Acabava de chegar de Minas, negra como um tição, dentes brancos como o leite, cabelos encaracolados como um 'bom bril'. Assim que meu filho a viu, abriu um sorriso alegre e logo correu para o seu colo. A empatia entre os dois era flagrante, e Lucia aceitou ficar conosco.

Passaram-se quatro anos de feliz convivência. Ela passeava, viajava e nos acompanhava aonde fôssemos. Meiga e educada, transbordava de amor e carinho. Um dia, ela me contou que estava apaixonada pelo moço que conheceu à beira da represa. Que ia embora com ele.

E foi. Fugiu no dia de sua folga, durante nossa ausência, sem se despedir nem receber salário. Nunca mais a vimos. Um dia, eu e meu filho (então com 12 anos) estávamos olhando antigos álbuns de fotografias, quando nos deparamos com algumas fotos da Lucia. Qual não foi o meu espanto quando ele exclamou, como quem fez uma grande descoberta: 'Mãe, a Lucia é negra! Eu nunca tinha percebido isso!'

Luís Jardim. O meu pequeno mundo. Rio de Janeiro, Livraria José Olympio Editora, 1976.

“Nascia no dia 8 de dezembro de 1901, bonito dia de Nossa Senhora da Conceição, minha madrinha. O registro de nascimento confirma essa data, mas não assinala a hora: duas e meia da madrugada. A terceira hora matinal, incompleta, para Nanã era mau sinal, isto é indício de que minha vida seria complicada. Nanã, negra que me queria bem maternal, que me viu nascer, crescer e estava sempre ao meu lado como mãe preta, era a única pessoa a quem eu beijava. Extremada comigo, 
justificadora de minhas traquinices e má criações, é duvidoso que quisesse mais bem ao próprio filho, Ludugero, do que a mim queria. Grande mãe preta, de alma azul e pura." (p. 3)

“A fazendinha Mulungu era o meu paraíso sem limites. E lá as atrações eram tantas, tão diversas das poucas da cidade, que eu já sentia por antecipação o desprazer da volta. Duas tristezas eu levava comigo: ausência do meu cajueiro e de Nanã. (...) O Mulungu caprichou para me receber." (p. 27)

“Nanã tivera uma sonho mau. Vira como que de verdade, com toda aparência de realidade, eu me queimar com os fogos de São João. (...) Por isso tinha vindo [a pé, andou dez léguas, venceu sessenta quilômetros contados] ao Mulungu implorar em nome de deus e de todos os santos, em particular São João, que a minha mãe não consentisse que eu naquele ano soltasse sequer uma estrelinha." (p. 58)

Jorge de Lima. "Novos Poemas" in: Poesia Completa vol. I. Rio de janeiro, Nova Aguilar, $\underline{1929 / 1974 .}$

ESSA NEGRA FULÔ

Ora, se deu que chegou

(isso já faz muito tempo)

no bangüê dum meu avô

uma negra bonitinha

chamada negra Fulô.

Essa negra Fulô!

Essa negra Fulô!

Ó Fulo! Ó Fulô!

(Era a fala da sinhá)

- Vai forrar a minha cama, pentear os meus cabelos, vem ajudar a tirar a minha roupa, Fulô!

Essa negra Fulô!

Essa negrinha Fulô

ficou logo pra mucama, para vigiar a Sinhá pra engomar pro Sinhô!

Essa negra Fulô! Essa negra Fulô!

Ó Fulô! Ó Fulô!

(Era a fala da Sinhá)

vem me ajudar, ó Fulô

vem me abanar o meu corpo

que eu estou suada, Fulô!

vem me coçar minha coceira, 
vem me catar cafuné, vem balançar minha rede, vem me contar uma história, que eu estou com sono, Fulô!

"Era um dia uma princesa que vivia num castelo que possuía um vestido com os peixinhos do mar. Entrou na perna dum pato saiu na perna dum pinto o Rei-Sinhô me mandou que vos contasse mais cinco."

Essa negra Fulô! Essa negra Fulô!

Ó Fulô? Ó Fulô? Vai botar para dormir esses meninos, Fulô! “Minha mãe me penteou minha madrasta me enterrou pelos figos da figueira que o Sabiá beliscou."

Essa negra Fulô!

Essa negra Fulô!

Ó Fulô? Ó Fulô?

(Era a fala da Sinhá chamando a Negra Fulô) Cadê meu frasco de cheiro que teu Sinhô me mandou?

- Ah! foi você que roubou! Ah! foi você que roubou!

O Sinhô foi ver a negra levar couro de feitor A negra tirou a roupa.

O Sinhô disse: Fulô!

(A vista se escureceu que nem a negra Fulô.)

Essa negra Fulô!

Essa negra Fulô!

Ó Fulô? Ó Fulô? Cadê meu lenço de rendas cadê meu cinto, meu broche cadê meu terço de ouro que teu Sinhô me mandou? 
Ah! foi você que roubou.

Ah! foi você que roubou.

Essa negra Fulô!

Essa negra Fulô!

O Sinhô foi açoitar sozinho a negra Fulô.

A negra tirou a saia

e tirou o cabeção

de dentro dele pulou

nuinha a negra Fulô

Essa negra Fulô!

Essa negra Fulô!

Ó Fulô? Ó Fulô?

Cadê, cadê teu Sinhô

que nosso Senhor me mandou?

Ah! foi você que roubou,

foi você, negra fulô?

Essa negra Fulô! (p. 119-121)

\section{SERRA DA BARRIGA}

\section{Serra da Barriga!}

Barriga de negra-mina!

As outras montanhas se cobrem de neve,

de noiva, de nuvem, de verde!

E tu, de Loanda, de panos-da-costa,

de argolas, de contas, de quilombos!

Serra da Barriga!

Te vejo da casa em que nasci.

Que medo danado de negro fujão!

Serra da barriga, buchuda, redonda, Do jeito de mama, de anca, de ventre de negra! Mundaú te lambeu! Mandaú te lambeu!

Cadê teus bumbuns, teus sambas, teus jongos?

Serra da Barriga,

Serra da Barriga, as tuas noites de mandinga, cheirando a maconha, cheirando a liamba?

Os teus meios-dias: tibum nos peraus!

Tibum nas lagoas!

Pixains que saem secos, cobrindo

sovacos de sucupira,

barrigas de baraúna!

Mundaú te lambeu! Mundaú te lambeu!

De noite: tantâs, curros-curros

E bumbas, batuques e baques! 


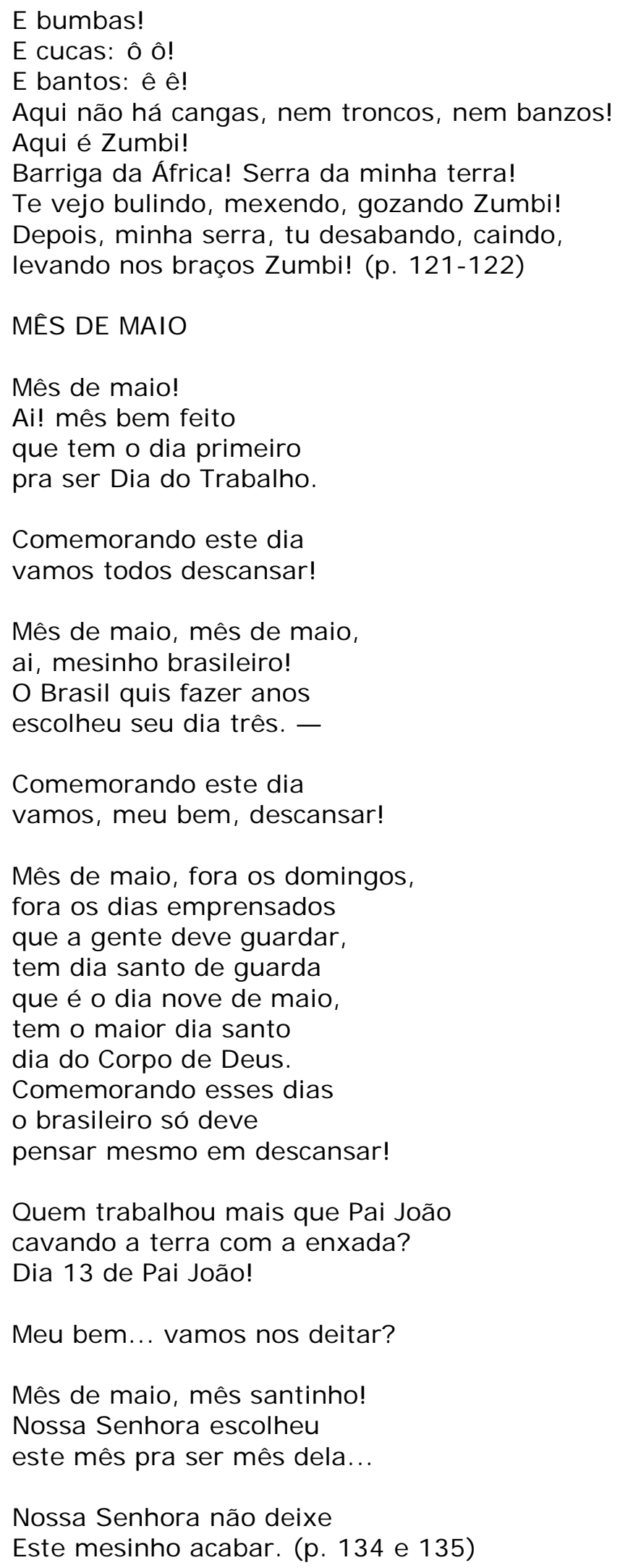


Jorge de Lima. "Poemas Negros". In: Poesia Completa - volume I. Rio de Janeiro, Nova Aguilar, 1947/1974.

\section{DEMOCRACIA}

Punhos de redes embalaram o meu canto para adoçar o meu país, ó Whitman.

J enipapo coloriu o meu corpo contra os maus-olhados, catecismo me ensinou a abraçar os hóspedes, carumã me alimentou quando eu era criança, Mãe-negra me contou histórias de bicho, moleque me ensinou safadezas massoca, tapioca, pipoca, tudo comi, bebi cachaça com caju para limpar-me, tive maleita, catapora e ínguas, bicho-de-pé, saudade, poesia;

fiquei aluado, mal-assombrado, tocando maracá, dizendo coisas, brincando com as crioulas vendo espíritos, abusões, mães d'água, conversando com os malucos, conversando sozinho, emprenhando tudo que encontrava, abraçando as cobras pelos matos, me misturando, me sumindo, me acabando, para salvar a minha benzida e meu corpo pintado de urucu, tatuado de cruzes, de corações, de mãos-ligadas, de nomes de amor em todas as línguas de ranço, de mouro ou de pagão. (p. 164-165)

\section{ANCILA NEGRA}

Há ainda muita coisa a recalcar Celidônia, ó linda moleca ioruba que embalou minha rede, me acompanhou para a escola, me contou histórias de bichos quando eu era pequeno, muito pequeno mesmo.

Há muita coisa ainda a recalcar; As tuas mãos negra me alisando, os teus lábios roxos me bubuiando, quando eu era pequeno, muito pequeno mesmo.

Há muita coisa ainda a recalcar ó linda mucama negra, carne perdida, noite estancada, rosa trigueira, maga primeira.

Há muita coisa a recalcar e esquecer: o dia em que te afogaste, 
sem me avisar que ias morrer, negra fugida da morte,

contadeira de histórias do teu reino, anjo negro degredado para sempre,

Celidônia, Celidônia, Celidônia!

Depois: nunca mais os signos do regresso.

Para sempre: tudo ficou como um sino ressonando.

E eu parado em pequeno, mandingando e dormindo,

muito dormindo mesmo. (p. 170-171)

FOI MUDANDO, MUDANDO

Tempos e tempos passaram

Por sobre teu ser.

Da era cristã de 1500

até êstes tempos severos de hoje, quem foi que formou de novo teu ventre, teus olhos, tua alma?

Te vendo, medito: foi negro, foi índio ou foi cristão?

Os modos de rir, o jeito de andar,

pele,

gôzo,

coração...

Negro índio ou cristão?

Quem foi que te deu esta sabedoria, mais dengo e alvura,

Cabelo escorrido, tristeza do mundo,

desgôsto da vida, orgulho de branco, algemas, resgates, alforrias?

Foi negro, foi índio ou foi cristão?

Quem foi que mudou teu leite,

teu sangue teus pés,

teu modo de amar,

teus santos, teus ódios,

teu fogo,

teu suor,

tua espuma,

tua saliva, teus abraços, teus suspiros, tuas comidas,

tua língua?

Te vendo, medito: foi negro foi índio ou foi cristão? (p. 174-175)

OLÁ! NEGRO

Os netos de teus mulatos e de teus cafuzos

e a quarta e a quinta gerações de teu sangue sofredor

tentarão apagar a tua cor!

E as gerações dessas gerações quando apagarem

A tua tatuagem execranda,

não apagarão de suas almas, a tua alma, negro!

Pai-J oão, Mãe-negra, Fulô, Zumbi,

negro-fujão, negro cativo, negro rebelde, 
negro cabinda, negro congo, negro ioruba, negro que foste para o algodão de U.S. A.

para os canaviais do Brasil,

para o tronco, para o colar de ferro, para a canga

de todos os senhores do mundo;

eu melhor compreendo agora os teus blues

nesta hora triste da raça branca, negro!

Olá, Negro! Olá, Negro!

A raça que te enforca, enforca-se de tédio, negro!

$E$ és tu que a alegras ainda com os teus jazzes,

com os teus songs, com teus I undus!

Os poetas, os libertadores, os que derramaram

babosas torrentes de falsa piedade

não compreendiam que tu ias rir!

E o teu riso, e a tua virgindade e os teus medos e a tua bondade

mudariam a alma branca cansada de todas as ferocidades!

Olá, Negro!

Pai-J oão, Mãe-negra, Fulô, Zumbi,

que traíste as Sinhás nas Casas-Grandes,

que cantaste para o Sinhô dormir,

que te revoltaste também contra o Sinhô;

quantos séculos há passado

e quantos passarão sobre a tua noite,

sobre as tuas mandingas, sobre os teus medos, sobre tuas alegrias!

Olá, Negro!

Negro que foste para o algodão de U.S.A.

O que foste para os canaviais do Brasil

Quantas vezes as carapinhas hão de embranquecer

Para que os canaviais possam dar mais doçura à alma humana?

Olá, Negro!

Negro, ó antigo proletário sem perdão,

proletário, bom,

proletário bom!

Blues

Jazzes,

songs,

I undus...

Apanhavas com vontade de cantar, choravas com vontade de sorrir,

com vontade de fazer mandinga para o branco ficar bom, para o chicote doer menos,

para o dia acabar e negro dormir!

Não basta iluminares hoje as noites dos brancos com teus jazzes, com tuas danças, com tuas gargalhadas!

Olá, Negro! O dia está nascendo!

O dia está nascendo ou será a tua gargalhada que vem vindo? 
Olá, Negro!

Olá, Negro! (p. 179-181)

Jorge de Lima. "Poemas" in: Poesia Completa vol. I. Rio de Janeiro, Nova Aguilar, 1927/1974.

O MUNDO DO MENINO IMPOSSÍ VEL

Fim da tarde, boquinha da noite com as primeiras estrelas

e os derradeiros sinos.

Entre as estrelas e lá detrás da igreja, surge a lua cheia

para chorar com os poetas.

E vão dormir as duas coisas novas desse mundo:

o sol e os meninos

Mas ainda vela

o menino impossível

aí do lado

enquanto todas as crianças mansas

dormem

acalentadas

por Mãe-negra Noite.

O menino impossível

que destruiu

os brinquedos perfeitos

que os vovós lhe deram:

o urso Nürnberg,

o velho barbado jugoeslavo,

As poupées de Paris aux

cheveux crêpés,

o carrinho português

feito de folha-de-flandres,

a caixa de música checoslovaca,

o polichinelo italiano

made in England

o trem de ferro de U.S.A.

e o macaco brasileiro

de Buenos Aires

moviendo la cola y la cabeza.

O menino impossível

que destruiu até

os soldados de chumbo de Moscou

e furou os olhos de um Papá Noel,

(...) (p. 73) 


\section{OLHADO}

Menino Jesus de Deus e da sagrada luz

que a mãe santa deu à luz

numa segunda-feira

do santo J ordão na beira

que o Santo Cristo benzeu

que Maria concebeu

que homem feito cresceu

sem tremor de olhos e olhados

em nome dos santos rezes

eu te benzo

eu te livro

eu te curo

eu te sarvo

com 3 cruzes no teu peito

com 3 cruzes nos teus olhos.

E as 7 cores cantaram sons em redor do menino.

E a sala amarela,

a cortina encarnada,

olharam o arco-íris que estava dentro de seus olhos.

Ele sorriu.

E as sete cores saíram dos olhos

e subiram nas cortinas,

no jarrinho,

na mesinha,

na santinha da parede;

e o sol desceu do monte

com o ouro da mina encantada

e tingiu de cor de ouro o cabelo do menino.

E a mãe-negra deu uma gargalhada mais clara

que o ziguezague do raio que sai do ventre da noite. (p. 93)

PAI J OÃO

Pai J oão secou como um pau sem raiz. -

Pai J oão vai morrer.

Pai J oão armou nas canoas. -

Cavou a terra.

Fez brotar do chão as esmeraldas.

Das folhas - café, cana, algodão.

Pai J oão cavou mais esmeraldas

Que Pais Leme.

A filha de Pai João tinha um peito de

Turina para os filhos de ioiô mamar:

Quando o peito secou a filha de Pai J oão

Também secou agarrada num

Ferro de engomar

A pele de Pai João ficou na ponta

Dos chicotes. 
A força de Pai João ficou no cabo

Da enxada e da foice.

A mulher de Pai J oão o branco

A roubou para fazer mucamas.

O sangue de pai J oão se sumiu no sangue bom

Como um torrão de açúcar bruto

Numa panela de leite. -

Pai J oão foi cavalo pra os filhos do ioiô montar.

Pai J oão sabia histórias tão bonitas que

Davam vontade de chorar.

Pai J oão vai morrer.

Há uma noite lá fora como a pele de Pai João.

Nem uma estrela no céu.

Parece até mandinga de Pai J oão. (p. 110 e 111)

O MEDO

O bicho Carrapatu,

o negro velho do surrão

- foi o medo que passou.

Mas depois chegou o medo,

o medo maior que houve

que as negras velhas contavam:

era a mula sem cabaça,

era a cabra cabriola,

lobisomens, bestas-feras.

A gente sabia quem era a mula sem cabeça

O lobisomem era o Zuza-foqueteiro.

Pelo sinal da Santa Cruz...

E a vovozinha: Reze a oração de Nossa Senhora do Desterro.

A gente rezava.

O medo tremia o queixo da gente, mas lá ia...

O engenho de minha avó

era cheio de almas penadas

que vagavam nas senzalas abandonadas.

O engenho de minha avó era tão triste!

No tempo do cólera,

morreu gente como bala.

Na seca de 77 não ficou raiz de imbu...

As pedras do rio tinham letreiros de botijas

que ninguém descobriu. 
Quando a vovozinha morreu

$\mathrm{O}$ resto da gente partiu para o Juazeiro.

Pelo sinal da Santa Cruz... (p. 113)

Monteiro Lobato. O Sacy-Perêrê: Resultado de um inquerito. Gráfica JB S.A., Rio de Janeiro, 1918/1998. Edição fac-similar.

\section{DEDICATÓRIA:}

‘À memória da saudosa tia Esméria, e de quanta preta velha nos pôz, em criança, de cabellos arripiados com histórias de cucas, sacys, e lobis-homens, tão mais interessantes que as larachas contadas hoje aos nossos pobres filhos por umas lambisgóias de touca branca, n'uma algaravia teuto-ítalo-nipônica que o diabo entenda. Vieram estas corujas civilisar-nos; mas que saudades da tia velha que em vez de civilisação requentada a $70 \$ 000$ réis por mez, afora bicos, nos apavora de graça!"( Sem página no original.)

"O Saci-Pererê, [é] obra resultante de um inquérito realizado pelo autor em 1918 entre pessoas de São Paulo e Minas Gerais. Surgem, aqui e ali, nesse livro, testemunhos da existência desses negros e negras anônimas contadores de estórias. Aparecem assim o Zé Camilo, que contava estórias de mula-sem-cabeça botando fogo pelos olhos e 'que foi em vida moça de padre'; o pai Adão, a tia Liberata; a figura da tia Rita; a velha Lelê; a preta Generosa; o negro velho Adão e tantos outros." (p. 59)

"Meu pae não ia a clubs; e a mamãe não tinha criadas; era ella quem á noite, emquanto a senhora e o senhor iam ao theatro cuidava dos meninos e os adormecia embalados nos seus contos singelos. A innocencia não tem gerarchias; por isso ao lado dos pequenos Henrique, Pimpolho, Olga e Nenê, esta bem pequenina e com direito ao collo da sua velha Anna, nós outros assentados em torno do tapete, iamos ouvindo, ouvindo, até que vencidos pelo somno, cada um ia carregado para o leito sorrindo a dormir...". (p. 23- 24)

"Quem me contou, ha mais de 40 annos a historia ou, melhor, as historias dele, do capetinha, foi minha mãe, foi a Vuvô da Chacara, Tia Marinha, Tia Chica, foi a velha Theodora...". (p. 27)

"Affirma não haver crianças desconhecedoras do Sacy, cuja tradição Ihes é transmittida pelas amas e crioulinhos. Familias ha, entretanto, nas capitaes, cujos filhos são desnacionalisados desde o berço pelas amas estrangeiras. Os pequenos chupam leite de gallega para começar; guia-lhes os primeiros passos uma italiana; o desenvolvimento do espirito é norteado por governantas inglezas ou allemãs cujas historias, se as contam, são cousas tendentes a desapegal-os da terra. Revolta-o esta xenomania. Quer cada roca com seu fuso. Cita Grecia. Cita Angiulli, recentemente posto em voga pelo sr. Adalgiso Pereira com grande magua do sr. Papaterra. E prova que para termos bons nacionalistas é mister crial-os do berço, com leite caracú e sacys." (p. 49)

"Quem me contou da existencia do Sacy foram pretos velhos, ex-escravos de meus avós e tio-avós, que diziam ter visto o Sacy (...)" (p. 63)

"Descreve uma velha tia Rufina, moradora em palhoça de sapé, e da qual ouviu as primeiras historias maravilhosas. D'entre ellas as de Sacy eram recebidas pela 
criançada com especial encanto. Do Sacy nos falava ella de modo que nunca saberei repetir." (p.67)

"O Sacy, como m'o pintava sempre Joanna, a mucama que me criou, o 'mardito', como ella o chamava, era (...). (p. 77)

"Quantas vezes, após a fadiga do dia, eu ouvi contar, quando criança, pelas velhas escravas libertas em 88 , a historia fantastica desse moleque, a coxear pelas estradas, um barrete rubro enterrado na cabeça de simio, um cachimbo apagado no canto da bocca, em esgares grotescos, á espera do viajante? A todos que passassem, assim m'o narravam as supersticiosas pretas, carregando mais as côres no calor das descripções macabras, pedia fumo para o pito, e fogo. Ai de quem não o attendia!" ( $p$. 85)

"Affirmam os velhos africanos escravos que o diabo (...). As primeiras apparições do Sacy deram-se no tempo da escravatura, nas grandes fazendas, cujos propietarios eram senhores de muitos captivos. O incorrigivel demoninho tinha grande predilecção pelos monjolos, moinhos, engenhos e frequentava, com especialidade, as cozinhas, senzalas, os sambas e batuques dos pretos. Numa grande propriedade agricola, onde passei parte de minha infancia, os escravos viram-no muitas vezes e chegaram a trocar com elle não poucos desaforos. Desses escravos destacarei apenas dois, o pae Adão e a tia Liberata, ambos velhos, estimados, muito acatados e incapazes de invencionices.

Uma vez, conta pae Adão, (...). Ora ninguem pode negar que o Adão tivesse visto o Sacy. Este velho africano foi sempre modelo de probidade. Tia Liberata (outro modelo de probidade) certo dia (...). (p. 95-96)

"No dia seguinte fui á casa da tia Rita, (uma preta mina de oitenta annos), e a ellla contei o que havia passado e perguntei-lhe o que era o tal Sacy-perêrê e o que elle fazia. Ella se benzeu e começou:

'Cluze in cledo minha Deuse du céu; u Sacy Serumperêrê é um cuviteiru du demoniu; zêli quandu tá soltu, pinta u canecu: xega nas cuzinha, québa tudu us platu das partilleiras; vai nu fugãu distampa as panella; faiz maridu brigá cá muié di zêli; i até lagá un du ôtru; Sacy presegue as quiança anti di batisa; sacy, pita (nus pitu das negra), i dispoise enche pitu di istrumo de caçoro. Sacy rôbô uma quiança e foi botá nu matu purque zêli num xamava Malia; pur issu qui in tuda casa, até di sinhô blancu tem quiança cú nomi de Malia u Jusué; purque tendu, tá livi di Sacy Serumperêrê vim busca zêllis. Deuse ti livi, meu zifillu, du danadu do Sacy Serumperêrê. Cluze Cluze in credu!'

E tornou a benzer-se. Assim foi o pavor que soffri nos meus tempos de criança." (p. 100)

"Quanta boa prosa dei ao meu illustre amigo Emilio Pestana, no escriptorio commercial da rua do Rosario, quantas vezes fui 'aquentar' fogo na casa do velho redactor da 'Provincia'alli por trás da antiga cadeia a ouvir a cozinheira contar as minhas artimanhas á criançada, quantas..." (p. 118)

"Segundo me contou um a preta velha e leal amiga de todos os meus, o Sacy, (...) Sendo muito mau, foi expulso do inferno e condemnado a viver na terra, a 'assombrar todo mundo', conforme expressão da boa e saudosa Lelê. Em minha meninice, parte passada na fazenda de meu avô paterno, (...) o Sacy exercia uma influencia extraordinaria, não só no espirito da criançada, como tambem no de muito negro velho e muito caboclo credulo. (...) E, a despeito de meu pae - que não 
embarcava nessa canôa - me fazer sentir a falsidade de tal crendice que enchia de pavor o meu espirito infantil, a figura macabra do Sacy mais se accentuava em mim, em face das historias fantasticas que as pretas da fazenda me contavam." (p. 119 e 120)

"(...) A Generosa morava p'ra lá da aguada; a preta velha esclarecia tudo. E, sem demora, quando falaram, a preta respondeu que o Sacy morava lá (...). Dito e feito. E a preta mandingueira recebeu a paga do seu conselho - uma leitoinha gorda." (p. 124 e 125).

"Uma preta que nos serviu de ama dizia-me que o Sacy adorava um pedaço de toucinho bem cozido."(p. 129)

"Em minha terra quem mais padece do Sacy são as cozinheiras, as pretas sobre todas. As senhoras donas de casa que se presam exigem que as panellas sejam bem limpas, os pratos bem lavados, a comida sem corpo estranho algum. A cozinheira, diligente, ciosa do bom nome de perfeita em sua arte, logo pela manhan se entrega aos seus labores (...).

- 'Joanna! Grita a patrôa. Põe o almoço.' E lá vem ella, a cozinheira com os pratos fumegantes para a mesa. À vista da cozinheira que pelos pratos relanceou os olhos, nenhum corpo estranho se apresentou. Entretanto os patrões encontraram: na verdura, um pequeno caramujo (...)! A cozinheira volta logo o pensamento para o Sacy diabolico que talvez alli esteja num canto da cozinha, invisivel, em gargalhadas!" ( $p$, 137 e 138)

"De todos elles, porém, ocorre-me relatar o que me foi narrado pela ex-escrava Isaura, na minha infancia. (...) Mas seja porque fosse velha ou porque a monotonia da reza tivesse o effeito de um narcotico, o certo é que d. Candida, adormecia em meio desse exercício espiritual sem ultimar contagem dos tentos do seu rosario. E, então, para livrar-se desse peccado mortal a boa da velhinha cada vez que acordava, sobresaltada, recomeçava, de novo, o seu terço. Assim ficava até horas mortas da noite tentando concluir a oração sempre recomeçada e jámais terminada porém sacrificando a sua paciente escrava Isaura que a pé firme, por trás da rêde, emquanto a ama se detinha num mixto de reza e somno, friccionava-lhe a cabeça, praticando o chamado 'cafuné' tão apreciado naqueles tempos e religiosamente appetecido por d. Candida. (...) No entanto, ao ouvir a criada e as confirmações, a velha matrona, recolhida, persignou-se toda tremula: e, dahi em diante, nunca mais dormia quando rezava o terço, o que fazia de um só folego, para regalo de Isaura, que resmungando dizia á Palmira, outra serva: - 'quai Sacy o que... o Sacy foi esta mão que ta qui (mostrando a mão direita) o diabo da véia não deixa a gente drumi." ( $p .140,141$ e 142)

"Não ha brasileiro que não conheça, de tradição, este estranho personagem. Durante a infancia, nossa convivencia com os criados e para aquelles que nasceram e cresceram no interior, o convivio com as amas, com os velhos pretos ex-escravos e com os caboclos, fizeram com que se nos arraigasse no espirito, ainda em desenvolvimento, nessa edade, a idéa da existencia de fantasmas e duendes, de demonios e capetas, de Sacys e assombrações. Depois crescemos, formamos o espirito, nos civilisamos e ainda nos restam de tudo isto vagas e saudosas lembranças. (...) Quem estas linhas escreve, nasceu e cresceu no interior, em convivio com os caboclos e com toda essa casta de gente, em cujo espirito está fortemente arraigada essa crença." (p. 147) 
"O Sacy actual, o moleque peralta, é a forma africana do genio indigena. Do lendario tupy, o que mais se assemelha ao Sacy, tal como nos legaram as abusões das nossas amoraveis mucamas, é o corupira." (p. 152)

"Numa antiga fazenda deste Estado fôra conservado um negro velho a quem o 13 de Maio não tivera a propriedade de lançar ao acaso, como a tantos outros que immediatamente abandonaram as tristezas das senzalas pela satisfação da liberdade plena, eternamente sonhada. Chamava-se Adão. A cabeleira curta e encarapinhada já se mesclava de não raros fios brancos, prova evidente na raça negra, de uma edade já muito avançada. O seu andar cadenciado e tropego fazia suppôr que durante largo tempo, escravo de algum senhor carrasco, tivesse arrastado uma pesada corrente que Ihe deixára o habito de cambaiar. Mau grado repetidas advertencias para que poupasse o resto de suas forças, que descansasse mais, o velho preto, por costume ou distração, trabalhava de sol a sol, sem treguas, pouco se lhe importando as torturas da canicula e os inconvenientes da chuva. Bom contador de histórias, logo á noitinha ficava cercado por rancho de crianças - e entre ellas eu - que ouviam com grande attenção o desfiar pausado de suas palavras arrastadas e confusas. De todas as suas historias aquella que mais me interessava e que sempre lhe pedia m'a contasse 'outra vez', era a do Sacy-perêrê. Quando, enfim, accedendo aos meus rogos elle se dispunha a repetil-a, o seu rosto retinto e luzidio tomava uma tal expressão de horror, que me causava medo. Na sua algaravia especial o antigo escravo começava invariavelmente por este teôr: (...)."(p. 155 e 156)

"Outra narrativa ouvi de minha criadinha, uma moça filha de antigos escravos (...)." (p. 160)

"A tia Balbina não tem medo de Sacy! Chama-o até: - 'Sacy cerêrê!' E elle responde: 'Accende o pito, siá Balbina'- e vem, pula-pulando, a tremer, com medo do rosario de 15 'padre-nosso'. Que pavor tinham os ingenuos, nesses ledos tempos, da tia Balbina, velha mineira que vivia retirada e só, numa tapéra, lá para a banda das 'Taipas'! (...) Reminiscencias dulcissimas... Saudades perennes do 'meu tempo' e da minha terra donde sahi há 26 annos e onde nunca mais pude voltar." ( $p .170$ )

"Regulava eu pelos meus 12 annos. Criado numa cidade litoranea do nosso Estado, era testemunha inconsciente das historias contadas pelas 'tias-velhas' que na sua pachorrenta vocação procuravam incutir no espirito da meninada credula e medrosa a existencia quasi palpavel desses bizarros habitantes dos logares malassombrados." ( p.175)

“Com horripilações de puro medo, ouvia tamanhinho, as convictas narrações ingenuas feitas pela velha preta Catharina, aggregada de casa, das não menos ingenuas diabruras do Sacy.(...)

- Quando a gente quer uma coisa difficil, nhônhôsinho, e só amarrar o Sacy num rosario de capim.

- Não te solto dahi, cabritinho, emquanto não me fizer isto! (...)

E Catharina ria-se aos guinchos, entretanto que eu vagamente pensava em amarrar o Sacy, obrigando-o a satisfazer meus utopicos desejos infantis. (...)

Não me enchia as medidas á imaginativa a descripção feita pela negra velha; era-me insufficiente á volupia do terror aquelle Sacy sem traços exaggeradamente pavorosos, terrificantes (...)

Catharina contava, repisava sempre as mesmas historias: crianças attrahidas com lindos engodos e promessas lindas, para o mato, onde as abandonava perdidas; (...)" (p. 177-179). 
"O J oão, um escravo de meu pae, conheceu um caboclo em Itú, que era na sua pittoresca linguagem, mais esperto que um saguy e mais ligeiro de pernas do que um veado. Esse caboclo, affirmava o João com a mais solida das convicções, conseguiu laçar um Sacy. E narrava por esta fórma a extraordinaria façanha: (...)

E rematando a sua historia tão pittoresca, tão cheia de côr local, o J oão accrescentava profundamente convencido: 'Dizem que foi assim que os Galvão fizeram fortuna'. Seria? Quem sabe, J oão!" (p. 188 e 189)

"Havia na fazenda onde fui criado, quasi nas divisas de Minas, um preto velho chamado 'Nhô Urbano', um perfeito conhecedor das lendas brasileiras. Contava-me elle historias do 'arco da velha' occorridas na redondeza, com pessoas suas conhecidas e com elle mesmo, historias terrificantes de fantasmas e assombrações e com tal convicção as narrava que duvida alguma sobre a realidade dellas ficava-me no espirito infantil. Heroe predilecto de suas façanhas era o Sacy, que elle pintava da seguinte forma: (...)

De uma feita, ficando eu só no velho casarão da fazenda, pois toda a minha familia tinha ido a uma festa no 'arraiá', impressionado como andava com as historias ouvidas, não tive animo de dormir sem companhia no meu quarto. Appelei para a coragem do 'Nhô Urbano' que, muito satisfeito por ter uma occasião de prestar-me um serviço, veiu deitar-se ao pé da minha cama, sobre uma esteira. Para entreter-me contava elle as suas costumadas historias de Sacys. De repente um vulto negro passou entre nós e a lamparina apagou-se como por encanto. (...) Passados alguns minutos de terrivel silencio ouvi a voz sumida do 'Nhô Urbano' que me perguntava:

- 'Nhô moço, cadê o forfi?'

- Não sei, procure você, respondi-lhe eu.

E o pobre preto, fazendo das tripas coração, depois de muito esforço conseguiu levantar-se e accender a lamparina. A physionomia do velho estava transformada pelo medo e posso garantir-lhe, sr. redactor, que estava 'pallido'.

- 'Isto não pode deixá de sê trabaio do Sacy', garantiu-me 'Nhô Urbano'; 'é preciso esconjurá elle sinão nois tá perdido' (...)

Não lhe poso garantir, sr. redactor, se existiu ou não o Sacysêrê, pois nunca tive que tratar com tão extravagante personagem, porém, posso affirmar pela bocca do 'Nhô Urbano' (que Deus tenha sempre na sua santa companhia) que o Sacy é uma entidade real, realissima. O preto contava com tanta firmeza e convicção tel-o por muitas vezes visto que não nos seria licito duvidar das suas palavras. "' (p. 197-199)

"A velha Mariana, a preta Balbina, o Joaquim Custodio, o João Corrêa, o Venancio, o Manuel Creoulinho e tantos outros, contar-lhe-iam magnificas historias do dianho do Sacy. (...)

Lá estava o velho laranjal, onde, como dizia a velha Balbina, o 'peste' do Sacy fez tantas maluquices, no tempo de 'sinhô véio'. E, como outrora, quando, ao pé da lareira, na vasta cozinha do velho casarão, - ouvia das escravas as historias de assombrações, com os cabellos arrepiados, - pedi á boa velhinha que me contasse de novo a historia do sacy.

Cabeça alvejando, como uma pasta de algodão cardado, - tremula, - olhos baços, - mascando o cabo do velho pitinho de barro, - olhos de uma placidez de agua profunda, - ella, a bôa velhinha, contou-me:

'Sinhozinho: Sinhô véio tava duente. Istalêro tá cheio de purvio. Ingenho tava moendo.

Negro trabaiava inté gallo miudá treis vêis.

Vae, Sinhô véo mandô negra buscá herva cidrêra no laranjá, prumóde fazê chá prá Sinhô véio. Negra foi. (...) [tomou uma budoada do Sacy] 
Sinhô véio viu que negra tava demorando, - mandô Simião catá ella e Simão trouxe negra quaji morta, sinhôzinho!...

Foi alli mêmo, sinhôzinho.'

E a pobre sexagenaria, estendendo o braço tremulo, - apontava-me o velho laranjal. (...)

Para terminar, - mais esta historia, contada pelo Joaquim Custodio, - antigo capataz de meu avô." (p. 201, 202 e 203)

"Meu pae, lavrador em Silveiras, pequena cidade do Norte, quasi nas divisas do estado do Rio tinha diversos aggregados (assim se chamavam, lá, os trabalhadores que moravam nas fazendas), que, ao escurecer se reuniam no terreiro grande e deleitavam a criançada contando historias do lobishomem e do Sacy. Eu nunca faltava a essas reuniões, e ouvia sempre, com a maxima attenção, essas historias contadas na rustica simplicidade de trabalhadores da roça."(p. 205)

"Todas as narrativas que ouvi, foram contadas por pessoas 'populares'e crentes: algumas testemunhas oculares, outras victimas, outras favorecidas." (p. 211) Pirajú.

"A Maior parte da minha infancia passei-a na fazenda de meu pae, para além de

Foi ahi que desde a mais tenra edade soube da lenda do Sacy.

Mas, qual brasileiro que não recebe com o leite materno as superstições e lendas, tão abundantes no Brasil?

Poucos, bem poucos, são os que, no aprender o 'signal da cruz', não sejam instruídos das diabruras do Sacy, das devastações dos Lobishomens e da má fama do Caipora..." (p.213)

"Nunca tive medo delle, porque Dindinha (era como eu e meus irmãos chamavamos a velha ama que a todos nós pageara), nunca o considerara um mau diabo e, ao contrario disto, mantinha com elle transacções que lhe eram utilissimas, conseguindo do capetinha serviços inestimaveis por um preço infimo.

Não sei bem como Dindinha conciliava a sua fé catholica e suas relações com o capetinha; rezava o terço, accendia a lamparina do oratorio, fazia promessas aos santos e, todos os dias, dava um ovo ao sacy. Ella nos explicava que os santos vivem no céu e nos servem para depois da morte, ao passo que o capetinha, vivendo na terra, presta os seus serviços aos vivos que o tratarem bem." (p. 223-224)

"Uma preta velha que me iniciou nos terrores nocturnos, disse-me que o Sacy é primo do Satanaz expulso do inferno nem mais me recordo porque razão." (p. 242)

"A bôa 'Tia Rita', uma velha preta que me pageara, dizia com docilidade depois de me ver praticar um 'banzé':

- Oie, nhô Jogi, minino ansim é qui cigana loca gosta de pápá; sinão o Sacy garra paracê na hora de dromi fazeno um baruião cá sua perna de pau, a fazê micage, a puxá as coberta, e tocá musga, a gritá fino como araponga...

Naquella noite (era infallivel) eu dormia abraçado com minha 'maman', como a chamava, mas noutro dia, poucochinho mais comportado, não deixava de timidamente fazer novas travessuras: a criança 'mesmo um sacyzinho nas peraltagens.

Uma historia que me encheu de pavor foi a que me contara o Tristão, que era então empregado de nhô Faé, fazendeiro politico de minha terra natal, em cuja fazenda sempre eu passava férias. " (p. 249) 
Mello Moraes Filho. "Poemas da Escravidão" in: Cantos do Equador. Rio de Janeiro, Garnier Livreiro-Editor, 1881/1900.

AMA DE LEITE

Vinham bater á porta e vinham para vêl-a:

Era preta e retinta; a estatura d'ella

Não era alta, não; os modos seus, ufanos,

Mostrava apenas ter dezoito a vinte annos.

- "Não foi aqui, pergunta alguém que a pretendia,

Que annunciou-se um'ama em um jornal do dia?"

" - É certo, sim senhor;" de dentro brada antiga

Matrona e se levanta. - "Olá! ó rapariga!

Vem cá na sala, vem. Póde sentar-se. É viva

No serviço de casa, e saiba que é captiva!

Experimental-a é bom; depois, della não mude:

E que ateste o doutor; se goza ou não de saúde.

Engomma, lava e cose; em tudo ella é geitosa;

Sabe agradar criança, affirmo, é carinhosa

Como bem poucas há. Em quanto aos aluguéis,

Por ser para quem é, são 60 mil réis."

- "Seu filho?!"

A pobre escrava a entristecer-se toda, Murmura:

“Meu senhor, meu filho foi p'ra roda." (p. 173)

\section{PARTIDA DE ESCRAVOS}

(...)

Sabeis o que elles passaram?

O que passam nos caminhos

Esses pobres perseguidos,

Esses filhos sem carinhos?

$(\ldots)$

Conduz a escrava os filhinhos;

E, contra o seio as mãos postas,

Caminha tendo o mais moço

Atado a um panno nas costas.

$(\ldots)$

Um colloquio se deu; e, lacrimosa,

À porta, uma mulher

Implora de joelhos: - "Meu senhor,

Venda a mim, se quizer!"

"São as crianças lindas...

Vêdes? a escrava é boa;

Vendo-as por qualquer preço,

Vendo-as por cousa a tôa.

Traze teus filhos, negra!"

"Só dois? pergunta um d'elles. 
E os outros? É negócio;

Aquelles? sim... aquelles?

Se convier na troca,

Por mim, 'stá tudo feito;

Eu fico com os moleques

Que não servem p'r'o eito."

- "Quer a senhora apenas

Que me desfaça d'estes;

Podeis contar, aposto,

Perdi... Vós não perdestes!"

O vendedor de escravos

Em pagal-os se occupa;

Os toma e do cavalo

Suspende-os á garupa.

O' céos! a minha penna

Vacilla e se contrista:

Materno olhar segui-os...

Que desvairada vista!...

N'um circulo de fogo

Acaso o escorpião

Já viste s'estorcendo

E s'enroscando em vão?

E n'essa luta infrene,

Suprema, enfurecida,

A si mesmo voltando

O dardo suicida?

Assim a mãe captiva

Se debatia afflicta;

Depois, hirta, perplexa,

De pé, muda, contricta,

Retoma, um gesto horrendo...

Enfia as mãos à boca...

Coitada! A pobre escrava

Tinha ficado louca!... p. (174-178)

\section{A NOVENA}

(...)

Os escravos seguiam... uma escrava

Quasi que vem de rastos!

E aquece o filho que sorrindo brinca

J unto aos seus seios castos.

Vira a escada, o sol dourando o tôpo,

E sonhou com a partida;

Não queria morrer! oh não se morre

Quando se deixa a vida!

Oito dias de surra não bastavam 
Aos odios canibaes!

A fazenda tem leis; são nove dias;

Era um dia de mais!

A criança tomaram de seus braços,

Que foi morder o pó;

Se erguendo cambalêa, quer seguil-a...

Tão pequenina e só!

Jungida ao poste a pobre da captiva,

Regaçam dois feitores

A manga - e estiram do chicote as pontas, Oh! que quadro de horrores!...

Gemidos abafados... pranto... sangue...

Que revoltante scena!

Rebentam chagas... Bravo! - diz um d'elles, - São as rosas da novena! (p. 180-181)

\section{OS FILHOS}

Elle vendera a escrava e mais as duas crias;

Uma, depois da lei, só tinha quinze dias:

Estatua do infortúnio, a dor mais cruciante

Que a misera levara ao seio agonisante,

Foi um supplicio atroz; o derradeiro adeus,

Um grito de blasphemia, um desafio aos céos!...

Tres longos annos, sim! de pranto e de martyrios

Ellla os curtiu sem tregoas: - ella com seus delírios!

- «Fui mãe, eis o meu crime; a condição o quer:

Não é serviço à escrava o ser também mulher?!...»

Assim pensava a triste. O duro captiveiro

Lhe consumira o corpo. Esforço derradeiro

A subscripção Ihe fôra: a graça soberana

Da bárbara mulher, que n'isso fez-se humana!

«Aqui tens teu papel, o preço está marcado

P'r'as crianças... Que a ti eu tenho destinado

Que ficas fôrra. Espera, espera o teu momento,

De meus netos por morte. Eu fiz meu testamento»

E quando ella sahira, horrenda de máu trato, Uma criança ao collo, outra sustendo um prato, Aonde a compaixão errante da cidade Redime o captiveiro aos pés da caridade...

Ella o encontrára e elle empalleceu de assombro;

Abaixa-se ao mais velho, os dois erguendo ao hombro, Com voz já quase extincta e os olhos já sem brilhos:

— «Esmola, meu senhor! P'ra libertar seus filhos!...» (p. 185-186) 


\section{MÃE DE CRIAÇÃO}

Era já velha a misera pretinha:

Tão extremosa como as mães que o são:

Era escrava, porém que o amor que tinha

Àquelle a quem foi mãe de criação!

Cuidava tanto delle... Quando o via

Dos estudos chegar, chegar-se à ella, Parece que a ventura se embebia,

Como um raio de luz, nos seios della.

Seu filho lhe morrera em tenra infancia...

A sorte dos captivos é a dos revezes!

Ella o criara, e d'alma n'abundancia

O consagrara filho duas vezes

Quizeram libertal-a; a liberdade

Tomou como uma offensa e não cedeu;

Depois... «Minha senhora, é caridade

Não me apartar do filho que me deu. »

Scismava alegre tanta scisma vaga,

Pedia a Deus por elle tanto, tanto,

Que só de crêl-o ausente era aziaga

A hora que o furtava ao seu encanto.

Mas os tempos passaram; tudo acaba;

Nem no sonho feliz o foi sequer!

Ha filhos-reptis que cospem baba,

Lethal veneno a um seio de mulher.

Elle o fizera. Áquela que os vagidos

De seu berço acudiu, ó mães bondosas,

Que velára, acalmando os seus gemidos

De criança, nas noites dolorosas,

Levou- Ihe ao rosto a mão matricida!...

A pobre velha lá mordeu o chão:

- «Com meu sangue de escrava dei- Ihe a vida...

à seus pés, meu senhor... perdão! perdão!» (p. 194-195)

\section{A FEITICEIRA}

É noite! E' meia noite! A selva brava

Resona ao vento solto na folhagem!...

Tudo é paz e descanço! Só a escrava

Sente a attração do abismo e da voragem!

Um passo, um passo mais, ao prado aberto

Ella pede o veneno, a morte ás flores.

Horror! ser mãe e ver-se n'um deserto!

Viva! - orphão seu filho aos seus amores!... 
Oh! Que longo pensar! Grilhões pesados

Do captiveiro arrasta a vida inteira!

Em torno - a prole vil dos desgraçados;

Pr'a tornal-a feliz - foi feiticeira.

Sim! Na calada das vigílias calmas,

Quando a onça boceja, ao abandono,

Fazia ella partir libertas almas

Aos succos acres que produzem somno.

O pastio lá 'stá, valles, barracos...

Scintilla o orvalho aos hervaçaes maninhos;

Arrêa á terra o gado o corpo, os flancos,

Muge e rumina á beira dos caminhos.

Ao candieiro aceso da senzala,

Ergue-se e espreita a solidão infinda;

A feroz crueldade o céo abala,

E o ódio no seu peito augmenta ainda!

A porta abriu: ninguém seu plano entrava!

Ella sabe: a planície é vasta e núa!

Escolhe plantas a Medéa escrava,

Banhando o rosto negro á luz da lua.

Raízes e cipós ella os conhece,

As soleneas fataes, a strychnina;

Pé ante pé deslisa, - a grama cresce;

$E$ as sementes espalha na campina.

Nos córregos d'além, nas fontes bellas, Quem não bebera a morte, o somno eterno?... Lealdade no ar, lumes d'estrellas, Ranger de dentes em su'alma-inferno.

Porque tanta vingança?... A feiticeira, Rindo na barca da escravidão perdida, Levar quizera á natureza inteira

D'esse vinho que estanca a sede á vida.

Porém, silencio! Eil-a, eil-a que torna... Uma velha... a infância... ai! pobresinhas!

Do seio um philtro arranca, ao labio entorna

D'alvorada da dor - das criancinhas.

Depois, sumiu-se; entrou n'esse aposento

Dos captiveiros do eito, ó sina horrenda!

Da justiça de Deus o algoz cruento,

- A negra feiticeira da fazenda! (p. 197 e 199) 
INGENUOS

[...]

- E onde a moradia

Que reserva aos demais?

Quero dizer, os quartos,

As casas dos casaes?

- Com a lei do ventre livre,

Que não nos traz proventos,

Achei desnecessario

Haver mais casamentos.

[...] (p. 201)

AVE, CESAR

[...]

Do levante, Senhor! revolta inconsciente.

Que quebra ao captiveiro o peso da corrente;

Sabeis, vós o sabeis que rude estrada trilha

O homem sem ter pátria, o homem sem família;

A pobre mãe que sonha a um meigo desvario

O embalar d'um berço - e o berço achar vasio!

[...] (p. 218)

Ofélia Fontes e Narbal Fontes. Pindorama - leitura para os alunos dos cursos primário e ginasial. Rio de Janeiro, Fernandes \& Rohe, 1932.

\section{REISADO}

\section{(...)}

“Foi quando Quitéria apareceu. Quitéria é mãe da Comadre. É baiana e quituteira como ela só. Sabe fazer manauê de milho verde, mal-casado, arroz de côco, beijú, mãe-benta, manjar-do-céu e tanta coisa gostosa, que nem sei! Usa colares de missangas, pulseiras e braceletes de todas as côres, argolas de prata nas orelhas, sandálias ringideiras e chale de pano da Costa. Enfim, é baiana até ali!

- Na Baía tambem se faz presepe? Perguntei-lhe.

- Ih! Nem fale, Ioiô! Lá é que se faz presepe bonito e ha cada festança de deixar a gente de agua na boca. Não é como aqui: uma festa sem graça, pirão sem sal. Se vosmicê fôsse lá é que havia de gostar.

No meu tempo, não sei se ainda hoje, havia presepes em toda a parte, bailes pastoris, côcos, cheganças, bumba-meu-boi...

- Bumba-meu-boi? Que é isso?

- O'xentes, então vosmicê nunca ouviu falar no bumba-meu-boi? Pois eu lhe conto.

- Então conte!

- Na minha terra, quando chega a véspera de Reis, ha um reboliço nas ruas: uma porção de ranchos, com archotes acesos, pandeiros, violões e castanholas. É o dia da visita aos presepes. As casas estão fechadas. Os donos fingem que não esperam ninguém. As moças brancas, mulatas e crioulas, vestidas de pastorinhas, chegam e cantam:

(Reprodução do canto...) (...)

Então, abrem a porta. O rancho entra, dança, canta e toca lá dentro, ao pé do presepe. 
A chegança é feita num palanque armado na praça. Aparecem dois navios, com almirantes, marinheiros e tudo. Um é cristão, outro é pagão. Os dois brigam e o cristão sai vencedor. Ha muita alegria, tocam pandeiros e canzás, canta tudo em côro e o povo que assiste acompanha.

E o bumba-meu-boi? É o mais engraçado! Aparece um homem com cabeça de boi, acompanhado pelo vaqueiro chamado Mateus, que principia cantando:

(Reproduz canto de Mateus e a resposta do coro...) (...)

E faz-se a roda e o boi começa a dançar e a investir a torto e a direito.

Quando a Quitéria acabou de contar, Iára estava embevecida. Ela também queria ver o boi dançar.

- Bem, loiô, vou chegando, botar as panelas no fogo.

E lá se foi Quitéria para a cozinha.

Depois Comadre, que sabe cantar todas essas coisas, ficou ensinando lára as cantigas do bumba-meu-boi:

De tarde, perguntei a lára se lembrava as histórias contadas pela Quitéria e do que ela gostou mais de tudo.

- De tudo?

- Sim.

- Gostei mais da vaca... (p. 21-24)

\section{DEMOCRACIA}

Amanhã é aniversário da antiga Constituição brasileira. É uma data extraordinária para o nosso coração.

Quando Quitéria e Dail me contavam histórias de reis e príncipes encantados, eu tinha pena de que, na nossa terra, não houvesse mais reis e princesas. I maginava o quanto seria imponente a passagem de um séquito real, o arauto à frente, anunciando aos quatro ventos a aproximação de El-Rei, com toda côrte. E o rei apareceria, com seu manto de púrpura, sua corôa de ouro e o seu cetro faiscante de pedrarias. Seria um espetáculo belíssimo!

Mais tarde aprendi, em casa e na escola, o quanto foi bom D. Pedro II, nosso último imperador, amigo dos artistas e dos cientistas, pobres, amante apaixonado de todas as nossas coisas. E a princesa Isabel, que assinou a lei aurea, sabendo que sacrificava o trono com êsse gesto? (p.58)

\section{COMADRE}

Isabel vai recitar uma poesia na escola, na festa de 13 de Maio! Hoje, o dia inteiro, nos distraímos com isso. Ela está muito compenetrada de sua importância. O entusiasmo é tão grande que repete os versos a toda hora. Foi o que nos valeu, porque todos nós quisemos ensaiá-la, como se a festa fôsse já amanhã.

Quitéria está encantada! Quando recebeu a notícia, encheu-se de modéstia, cravou no céu os olhos molhados de emoção e disse que não podia ser, que Isabel não se sairia bem, que era uma songa-monga... Mas nós insistimos, dizendo que a professora a escolhera porque a achára capaz de desempenhar o papel.

Quitéria no íntimo, tinha absoluta certeza disso, de modo que não oculta mais sua felicidade... Está que não cabe em si de contente!

Iára também: mostra-se, mais do que nunca, vaidosa de sua comadre. É um gôsto vê-la quando Isabel recita; esta pode dizer os versos da peor maneira possivel, porque Iára não deixa de contemplá-la embevecida! Chega-se à comadre depois, fazIhes carinhos, abraça-a; I sabel olha de soslaio, meio desconfiada, na atitude de quem foi promovida sem saber por que e recebe a homenagem imprevista. Mamãe diz que ela cresceu de importância, e é mesmo. 
Logo que Papai chegou, Iarinha foi buscar a comadre para recitar e começarem as recomendações:

- Olhem como vem sem jeito!

- Fale bem alto, I sabel!

- Bem explicado!

- Tire a mão da boca!

- Não fique olhando toda a vida para o chão!

- Largue o cinto!

- Deixem-se de tantos avisos, disse papai. Póde começar, I sabel.

- Meus senhores...

Que alegria...

- Meus senhores. Que alegria

Trago na alma infantil!...

Quando...

Quando nasci não havia

Mais escravos no Brasil!

- Muito bem! Muito bem! A quadrinha é muito bonita! Agora, peça a Dail que Ihe explique quem eram os escravos e o que se vai festejar no dia 13, aconselhou Papai.

Dail sentou-se na escada com a futura declamadora e se pôs a contar.

- Você já tem ouvido sua mãe falar nos escravos, não é?

Sabe que os pretos faziam todo o serviço dos brancos, trabalhavam nas fazendas e eram comprados por dinheiro, como se faz com os brinquedos e as balas... Pois bem: dêsses pobres escravos, alguns eram bem tratados, mas outros não tinham a mesma sorte e eram sempre castigados, amarrados ao tronco, chicoteados, acorrentados... Mas isso ainda era pouco: o que eles mais sentiam era serem separados dos filhos que não viam nunca mais! Porque muitos senhores vendiam os escravos sem se importarem com os parentes que êles deixavam.

Depois, uns homens bons começaram a ter pena dos escravos e se puseram a trabalhar para Ihes darem liberdade. Custou muito, porque os fazendeiros não queriam ficar sem aqueles criados que trabalhavam de graça. Os outros, porêm, esforçaram-se tanto que, afinal conseguiram o que desejavam.

Naquele tempo, o Brasil era governado por uma princesa muito boa, que tinha o mesmo nome que você - Isabel. Se ela não fosse assim boa, os escravos teriam continuado naquela vida tão triste! Porque princesa manda em tudo.

Foi no dia 13 de Maio que a escravidão acabou. Por isso, todos os anos nêsse mesmo dia, ha festa na escola.

Você reparou no que diz o verso? Que você está contente porque não havia mais escravos no Brasil, quando nasceu... É que faz bastante tempo que sucedeu isso. E não pense que é só você que fica alegre! Todo mundo! Todos os brasileiros! E sua mãe, então, nem se fala!

Ela era menina, naquele tempo, e viu tanta gente sofrer! Hoje, é quem poderá dizer a você quanto melhorou a sorte dos pretos. Agora, trabalha onde quer, recebe dinheiro pelo seu trabalho, da mesma fórma que as pessoas brancas; sabe que ninguem vai vender você e vive sossegada.

Você é pretinha, mas é tão querida como se fôsse branca, pois o que vale é ser boa. Tanto assim que lára quer bem a você como irmazinha, não é?

Aprenda bem a poesia para fazer um bonito na escola! Já sabe o que ela quer dizer e pode recitar entusiasmada! (p. 116-119) 
Oswaldo Orico. Contos da Mãe Preta adaptados à leitura das crianças. Série I, vol.1. Bibliotheca Infantil d'O TICO-TICO, Rio de Janeiro, 1932.

\section{CONTOS DA MÃE PRETA}

Chiquinho, como varias crianças, também teve sua Mãe Preta. Uma criatura simples e boa, que lhe embalou a imaginação com uma porção de historietas e contos.

Contos e historietas que andam espalhados por esse Brasil a fóra e são deliciosas reminiscencias de nossas velhas amas.

Chiquinho não se esqueceu. Oferecendo aos seus leitores e amiguinhos a BIBLIOTHECA INFANTIL D'O TICO-TICO, lembrou-se de reunir no primeiro volume as narrativas pitorescas que ouviu pela boca da Mãe Preta .

Mãe Preta, a nossa boa Scheherezada... Quando chegava ao terreiro, já de noitinha, enxugando as mãos no avental de chita, a pirralhada exigia, puchando-Ihe a saia;

- "Conta uma historia, conta uma historia". E ella, solicita, começava:

- "Era uma vez..."

Oswaldo Orico. Historias de Pae João - Contos do folk-lore brasileiro adaptados à leitura das crianças. Série I, vol.11. Bibliotheca Infantil d'O TICO-TICO, Rio de Janeiro, [1933].

"Estas histórias de Pai João, bem como os contos da Mãe Preta, com que a Bibliotheca Infantil do TICO-TICO iniciou a sua coleção, representam motivos de nosso populario adaptados à leitura das crianças.

O grande exito que despertou a publicação dos <Contos da Mãe Preta> pode ser explicado pela atração que sempre despertam no espirito de nossa infancia os ingenuos racontos das velhas amas...

É a tradição popular que os gera e alimenta, emprestando-lhes a graça, o encanto e o pitoresco de que se revestem.

Da mesma forma que Mãe Preta, Pae João é um symbolo do nosso lendario. Uma figura tão sugestiva para a imaginação das creanças como a da velha babá que nos embalou com suas cantigas de ninar, entoando o murucutú da beira do rio...

Em ambos os personagens aproveitamos os motivos correntes em nosso folklore, alguns dos quaes apresentados por autoridades do valor de Nina Rodrigues, Silvio Romero, Lindolpho Gomes e Basílio de Magalhães.

Nossa preocupação, alem de guardar a fidelidade das narrativas, foi restituir a esses contos a espontaneidade e a ingenuidade primitiva com que nasceram.

Obedecendo a esse critério, procuramos unir ao valor puramente recreativo o valor educativo, oferecendo à infância brasileira uma coletânea que ao mesmo tempo instrua e divirta.

O mérito principal deste livro é devolver às crianças, em linguagem simples e acessivel, as criações naturaes da alma do povo, fortalecendo-lhes o conhecimento de nossas tradições populares.

Para isso fomos buscar Pai J oão, velho amigo da nossa infância.

É Pai J oão que vae falar..." (p. 2)

\section{ANDORINHA, AMIGA DAS CRIANÇAS}

Zezinho saiu um dia de casa com uma baladeira, disposto a praticar alguma proeza. 
Virou, mexeu, quebrou o vidro de uma janela e acabou por acertar numa andorinha que fizera o seu ninho numa árvore do jardim. Foi ufano, mostrar a façanha a Pai J oão.

$\mathrm{O}$ velho ficou triste, muito triste. E disse ao menino:

- Zezinho, não faça mais isso meu branco. Vancê nem sabe a injustiça que fez com essa avezinha.

E avivando a memoria, contou ao menino esta lição:

(Serpente dominava a terra, mandava nos outros animais. Mosquito tinha de saber o melhor sangue para ela tomar: sangue de menino tenro. Andorinha cortou a língua do mosquito e tomou um bote de raspão da serpente, ficando uma falha no meio da cauda.)

(...) Pobre andorinha! Sacrificou-se por nossa causa. Felizmente ainda existe gente agradecida: em certos logares da America, as crianças ajudam-na a fazer seus ninhos e arrumam caminhos (sic) para agasalhá-las. As andorinhas são muito amigas das crianças. As crianças devem ser muito amigas das andorinhas.

No dia seguinte, após esta história, Zezinho era visto no quintal furando um tronco seco para agasalhar a victima. E nunca mais perturbou o vôo de uma andorinha. (p. 3-4)

\section{A FRITADA DE OVOS}

Pai João foi sempre muito traquina, muito esperto. Por isso êle perdoa às crianças quando fazem qualquer travessura. Si papai e mamãi querem castigar o guri porque buliu nos doces ou xingou a criada do vizinho, o negro velho intercede. Não deixa a criança apanhar. Nem sofrer castigo Acha que é da idade. Desde que a falta não seja grave, é melhor relevar. Depois a gente pede com bons modos que o menino não faça mais. O menino promete. No dia seguinte mexe no doce e xinga o vizinho. A gente fala de novo. E vai falando com bons modos, até que a criança pára de fazer. Nunca mais bole nos doces nem xinga pra casa do vizinho.

É que Pai João se lembra de que também foi criança. E que já Ihe sucedeu uma de rebimba o malho. Pai João tinha então seus nove pra dez anos. Trabalhava em casa de uma fazendeiro, que era o tipo do usurario. A mãi de Pai João, velha escrava, gemia na cozinha. Ele ajudava a mãi no serviço, descascava batata, lavava pratos, fazia miudezas. Era só. O fazendeiro achava isso pouco e resolveu dobrar-lhe o serviço, encarregando-o de ir apanhar os ovos no galinheiro, dar milho e agua à criação.

Receava, porém, o malvado fazendeiro que o guri lhe pregasse alguma partida, isto é, surrupiasse os ovos e êle ficasse a ver navios...

E usou de um estratagema para saber si podia confiar o serviço ao pretinho.

Chamou-o ao galinheiro e indagou:

- O' moleque! você gosta de ovos cozidos ?

— Eh! Eh! meu sinhô. Eu lá gosto disso, non sinhô.

- E de ovos assados?

- Eh! Eh! meu sinhô. Eu nen sê o que é isso, meu sinhô.

- E de ovos crús?

- Axi! ovo crú, meu sinhô! Gambá é que come ovo crú.

À vista das respostas, o fazendeiro deu-se por satisfeito. O negrinho não gostava de ovo. Detestava ovo cozido. Não sabia nem o que era ovo assado. E não era 
gambá para comer ovo crú. Estava bom para o serviço. Podia confiar nêle. E deu-Ihe um cesto enorme para ir diariamente ao quintal recolher os ovos que as galinhas houvessem posto. O tempo foi passando. O fazendeiro levantava-se tarde e aparecia de vez em quando para ver o serviço do guri. E dava-se por satisfeito. Tudo ia caminhando direitinho. Um belo dia, não sei o que deu na cabeça do homem que êle foi mais cedo ao quintal. Pai J oão ouviu de repente a porteira ranger.

Rim... rim... rim... Ficou tonto da vida. Não tendo tempo de esconder os ovos que fritavam na frigideira, e na iminencia de ser apanhado em flagrante, virou a frigideira no chapeu de couro que usava por causa do sol e enfiou o chapeu na cabeça. Em seguida foi atender o patrão que o chamava. Foi. Desconcertado, encabulado, mas foi.

Mal olhou para êle o fazendeiro viu a gordura da fritada correr-lhe pelo rosto abaixo. Perguntou-Ihe o que era aquilo. O garoto achou logo uma desculpa:

O sol tava quente, de rachar. Êle andara toda manhã. Por isso estava suando assim...

O fazendeiro acreditou; mas vendo que o guri, pela primeira vez, em sua presença, não se descobria, não tirava o chapeu, indagou com mau humor:

- Então que é isto, seu moleque? Não tira o chapéu diante de seu senhor?

O negrinho ficou hesitante, sem saber o que fazer.

- Vamos, descubra-se, tire o chapeu - ordenou o fazendeiro.

Não havia outra saida, Pai J oão teve de tirar o chapeu. E ficou com a fritada à mostra em cima do pixain.

O patrão, vendo aquilo, exclamou:

- Ah! seu maroto. Peguei-te. Então era assim que não gostavas de ovos, hein?!....E te metes logo numa fritada, ein?!...

O garoto gaguejou, gaguejou, mas ainda encontrou resposta:

- Eh! Eh! meu sinhô. Eu le disse, sim, que não gostava de ovo; mas o patrão quando me perguntou, falou em ovo cozido, ovo assado e ovo crú. Eu disse a meu sinhô que não. E não gostava mêmo; mas de ovo frito eu gosto, sim sinhô...

O patrão achou graça e o dispensou do serviço.

Quando recorda o fato e conta a história aos meninos, Pai João mostra-lhes como uma boa resposta pode, às vezes, livrar a gente duma bôa surra. (p. 5-7)

\section{LENDA DE SÃO J OÃO}

Pai J oão! Pai J oão! Conte a história de S. J oão! Conte a história de S. J oão!

Fazendo roda em torno do velho, as crianças pediam que o velho contasse a historia de S. João para elas ouvirem. Ali perto ardia uma fogueira. Assavam-se batatas doces, carás, aipins. Mais adiante um grupo de meninas soltava fogos, bichinhas, busca-pés, cauda de pavão, estrelinhas e pistólas.

Noite de alegria, de encantamento!

Pai João via aquilo e começava a contar às crianças:

[Maria e Izabel se visitam ambas grávidas. A primeira que desse a luz mandaria fincar um mastro na montanha próxima e acender, em torno dele, uma fogueira. Nasceu de Izabel São João Baptista e Maria foi visitá-la levando uma capelinha, um feixe de palha seca e folhas macias para cama do bebê. A criança se tornou apóstolo e ficou a lembrança de seu nascimento. As crianças festejavam S. João em torno da fogueira; e outros foram se juntando. As plantas levadas por Maria passaram a ser milagrosas]. 
Por aqui, hoje, só se jogam os joguinhos que papai ou mamãi vai buscar em Niterói para os festejos de junho. No interior do Brasil, porém o viajante que atravessa certas fazendas encontra freqüentemente um limão ou uma laranja fincados na ponta de uma vara. É a reminiscência do mastro que anunciou a Santa Maria o nascimento do filho de sua prima.

E ainda ouve as crianças, com umas corôas de mangerona e de trevos na cabeça fazerem roda em torno da fogueira, cantando alegremente:

$<$ Capelinha de melão,

É de S. João,

É de cravo, é de rosa

É de mangerição.> (p. 15-16)

\section{A SORTE DO OVO}

Pai J oão tinha contado ao Zéquinha uma porção de sortes de S. João. Entre elas a do ovo. Aquilo que era uma sorte e tanto. Quem fizesse podia contar que lia o futuro. Bastava quebrar um ovo dentro dum copo dagua e deixá-lo ao sereno da noite de S. João.

[Conforme a figura que se formava se revelaria a que a pessoa iria ganhar. Zéquinha usou os ovos de raça que seu pai ganhara e só conseguiu "ver" uma porção de fios, como se fosse um chicote de muitas pontas. Usou todos os ovos do pai que quando descobriu deu doze lambadas de chicote no filho, o mesmo número de ovos que havia usado na sorte].

$$
\text { (...) }
$$

O menino veio chorando contar a sua história a Pai J oão:

E o negro observou:

- Vancê qui é que viu no copo dagua?

O Zéquinha contou que tinha visto uns fiapos parecendo um chicote de muitas pontas. Julgou que ia ganhar um rebenque e um poneisinho.

- Ora, seu tolo. A sorte de vancê saiu certa. Tinha ae: panhá surra. O chicote que vancê viu no copo dagua era o chicote de Sinhô, que ia entrar em cena.

E voltando-se para os pirralhos:

- A sorte do ovo nunca falhou. (p. 17-19)

\section{A PANELA MÁGICA}

Pai J oão - perguntou uma vez o Juquinha - o senhor conheceu o Malazarte?

- Nêgo véio, conheceu, conheceu sim, minino. Era um diabrete assinzinho, parecido com vancê. Parecido, era escritinho mêmo.

- Pai J oão se lembra de alguma proeza do Malazarte?

- Ore se me alembro! si me alembro. Como se fosse hoje. Ora escuitem. $* * *$

Eu era menorzinho que vancês e já Malazarte andava pelo mundo pintando o sete. Minha mãe trabalhava em casa de um mascate que nos havia comprado. Esse mascate passava por bicho muito esperto. Gostava de embrulhar todo mundo. Fazia negócios da china. E queria ser mais sabido que toda gente.

Certa vez foi êle à feira, na cidade, fazer umas compras. E me levou em sua companhia que era para eu carregar os embrulhos. Quando foi aí pelo meio do caminho, o mascate, que se chamava Nicolino, avistou uma porção de gente em torno dum rancho. Gente em penca. Fomos para ver o que era aquilo. 
[Malazarte mostrava uma panela que cozinhava sem fogo. O mascate comprou a panela e estava convicto de que iria ganhar muito dinheiro, mas a panela não funcionou durante a demonstração que ele fez para o público. Malazarte havia dado um golpe escondendo debaixo da terra a brasa. O mascate depois disso nunca mais quis "embrulhar" ninguém]. (p. 32-33)

\section{O DIAMANTE DE PAI J OÃO}

Pai João, nêsse tempo, não tinha mais de vinte anos. Era um pretinho inteligente e esperto como quê! Morava lá pras bandas de Botafogo, numa pensão de estudantes. Servia a mesa, arrumava as camas, e à noite vinha brincar com os rapazes no jardim. Êle gostava da estudantada. A estudantada gostava dêle. E assim viviam muito bem.

Ali por perto morava um doutor chamado Pancracio Fernades. Um homem que não dava agua a pinto. Egoista que só êle. Vivia juntando dinheiro. Não dava esmola a pobre. Não convidava um amigo para jantar. Era um caso sério. Nunca oferecera nada a ninguém. Os estudantes conheciam-no muito bem. Trajava o mesmo fraque há muitos anos. Quando êle passava pela rua, de sapato amarelo e fraque preto, guardachuva e galochas, o pessoal só dizia:

- Lá vai o avarento! lá vai o avarento!

Um belo dia, quando êle passava pela casa, Pai João estava brincando no jardim com os meninos. E resolveu fazer uma aposta:

- Vocês duvidam como eu arranco um jintá dêsse doutô? Querem apostar como eu sento na mesa pra jintá com êle?

- Apostamos - responderam os meninos. Dez mil contra dez cascudos. Si ganhares, nós te daremos dez mil réis. Si perderes te daremos dez cascudos. Está feito?

- Tá feito - disse o pretinho.

Pai J oão foi lá dentro, calçou um sapato velho, penteou o pixain, botou camisa dum, a gravata de outro, o chapeu dêste, a bengala daquele e tocou-se pra casa do doutor. homenzinho.

- Eh! eh! minha gente. Venham todos ver como eu hoje vou jintá com o

Não houve quem acreditasse. No mínimo êle levaria um espirro e iria parar longe. E ainda apanharia dez cascudos. Toda estudantada acompanhou o pretinho. Queria gosar o espetáculo. Nem a proposito; a casa era de esquina. Havia uma janela na sala de jantar, janela essa que dava para a rua. A petizada comprou camarote de primeira classe ali defronte e ficou à espera. O espetáculo ia ser sensacional. $* * *$

O pretinho foi entrando pelo corredor sem pedir licença. Só quando chegou em frente à sala de jantar é que começou a bater palmas. O criado quis pô-lo para fóra; mas o pretinho logo avançou para o doutor, que nêsse mesmo instante ia se sentando à mesa.

O homenzinho ainda franziu as sobrancelhas irritado, carrancudo; mas o pretinho não Ihe deu tempo de desfechar a sua cólera. E perguntou-Ihe baixinho, quasi ao ouvido, com ar misterioso;

- Eh! Seu doutô, diga-me cá uma coisa. Uma pedra de diamante dêste tamanho (e, apontando para o bolso, deu com as mãos a idéia do tamanho de uma laranja) quanto é que vale mesmo? Quanto? 
O avarento, imaginando que o pretinho tinha, de facto, dentro do bolso, alguma pedra de alto valor, mais que depressa quis segurar o achado. E perguntou-lhe, para prendê-lo ali:

- Olá rapazinho! como vai você? Já comeu? Senta aí. O' Genoveva, traga prato e colher que o J oãosinho vai hoje comer com a gente.

O pretinho sentou e comeu tudo. A estudantada, lá fora, olhando a cena pela janela aberta, ficava banzando. Como é que o raio do preto havia conseguido aquilo? Ninguem sabia explicar. O pretinho era mesmo esperto. Esperto de verdade.

Entretanto, na sala de jantar, ansioso e aflito, o doutor esperava que o negro acabasse de jantar para conversar com êle particularmente. Queria ver o diamante. O pretinho demorou que não foi graça. Bebeu sopa e repetiu a sopa. Comeu peixe e bisou o peixe. Comeu galinha e pediu outra vez galinha. Serviu-se tres vezes de carne assada. De sobremesa, então nem se fala. Atracou-se com o queijo e a goiabada. Parecia não querer deixar mais o queijo e a goiabada. E a estudantada, lá fóra, com agua na boca, vendo o negro comer tudo aquilo...

Pai João já estava que não podia mais. Passou o guardanapo na boca e enguliu ainda uma chicara de café. O doutor esperava pacientemente. Quando êle acabou de tomar café, o homenzinho deu-lhe o braço e o levou para o escritório. Daí a estudantada não viu mais o que passava.

Chegando ao escritório, o doutor, todo amavel, disse ao pretinho:

- Então, vamos ver a pedra.

- Que pedra, <seu> doutô? - perguntou o rapaz.

- Sim, a pedra de diamante, aquilo que você achou.

- Eu, meu branco, não achei pedra nenhuma...

- Não achou! pois você, negro do diabo, não entrou aqui perguntando quanto valia uma pedra dêste tamanho? E não apontou para o bolso?

- Ah! Isso foi pra sabê. Que é pra quando achá já sabê o valô.

O doutor deu cavaco. Aquilo era um desaforo. Plantar-se um preto dêsses ali durante tanto tempo, filar-Ihe a boia e depois sair-se com essa... Desaforo!... Merecia pau. Caminhou para o quarto, com certeza para ir buscar o rebenque. Mas Pai João, que já lêra na fisionomia do velho o que êle ia fazer, saiu como entrou, sem dar boanoite, e foi ter com os estudantes, reclamando o dinheiro da aposta.

Os rapazes tiveram de pagar.

Dessa cena Pai João se recorda com saudade. Jantou como principe e ainda ganhou dez mil réis por cima.

[Nota - esta história pertence ao "Ciclo de Pai João" e foi coligida pelo douto folklorista brasileiro, Lindolfo Gomes. Dela há variante no "folk-lore" de varios países e uma versão do escritor francês Parme]. (p. 37-40)

\section{PAI JOÃO E A ESCOLA}

A mãe do Juquinha botou a cabeça fóra da janela e gritou para a petizada:

- Meninos, são noves horas. Vamos pra escola.

Os guris estavam brincando no jardim.

E não queriam largar o brinquedo. Foram direitinhos para o lado de Pai J oão que andava ali perto. E pediram:

- Pai João, deixa a gente ficar hoje brincando por aqui? Aquela escola é tão pau... A professora é tão ranzinza... 
Pai J oão era muito bonzinho. Gostava de fazer tudo o que os meninos queriam. Mas isso não seria possivel. Deixar de levá-los à escola? Nunca. Amansou a criançada. E foi contando pelo caminho:

- Vancês não gostam de Pai João? Gostam, não é?

Pois então ouçam isto e vejam para que serve a escola. Quando eu tinha por aí os meus trinta anos, já trabalhava com o avô de vancês. Servia de pagem a um menino muito inteligente, mas muito preguiçoso. Chamava-se Alfredinho.

- O papai? - perguntaram os guris.

- Sim, o papai de vancês, confirmou Pai João.

Nesse tempo êle não queria saber de estudar. O Pai João com jeitinho, com jeitinho, levava o menino pro colegio. O menino ia; mas ia chorando... No meio do caminho, Pai J oão viu um carneirinho pastando. E mostrou ao Alfredinho:

- Olha, nhônhô, vê aquele carneirinho ali, vê como está satisfeito, pastando? E nhônhô chorando...

O menino zangado da via respondia:

- Tambem carneiro não vai para escola; só eu é que vou.

- Mas nhônhô não come capim; o carneiro come...

Lá adiante encontraram o boi deitado na grama. Pai João, para fazer calar o menino, mostrava o boi.

- Oia, Alfredinho, vê lá aquele boi. Como está quietinho. Para que nhônhô fica chorando assim?

- Boi não vai pra escola, só eu é que vou.

- Mas nhônhô tambem não puxa carro; e boi puxa...

Caminharam mais um pouco e viram um preto cavando a terra e plantando cana. Pai J oão para conseguir que o menino ficasse quieto, mostrou o escravo suando:

- Oia nhônhô, oia preto como trabalha calado, contente. E nhônhô chorando desse jeito...

- Tambem preto não vae para escola: só eu é que vou.

- Mas preto não pode aprender; e nhônhô pode. Preto trabalha pra nhônhô ir aprender. Por isso nhônhô deve ter pena do trabalho do preto e ir pra escola direitinho.

Alfredinho olhou o escravo suando na lavoura e parou de chorar. Quando chegaram ao arraial, já o menino se mostrava alegre, satisfeito, Pai João deixou-o na escola. E voltou para casa sósinho.

Passaram os tempos. O pai de Alfredinho - avô de vancês - ficou velho, doente. E tinha que vender a fazenda pra viver - Pai João ia também ser vendido. Sabe lá para quem! Para algum brutamonte. Foi... quando, por felicidade nossa, Alfredinho, que tinha tomado gosto pela escola, veio da côrte feito doutor. Começou a curar gente. Onde êle botava a mão, o pessoal ficava bom. Em três mezes ganhou tanto dinheiro que não precisou nem mais vender a fazenda nem vender Pai João. Escutaram? Pai J oão está aqui com vancês, porque doutô Alfredinho, pai de vancês, escutou Pai João.

E abraçando a todos de uma só vez, o negro velho concluiu:

- Vamos rindo pra escola, nhônhôs, que Pai João ainda quer ficar aqui muitos anos e levar também para escola os filhinhos de vancês...

Entrou por uma porta, saiu por outra:

El-Rei, meu senhor, que vos conte outra. (p. 44-46) 
Cornélio Pires. Quem conta um conto... E outros contos (coisas de outrora). São Paulo, Livraria Liberdade, 1915/1943.

TARÁ BÃO DE SÁ?...

A sala da casa velha do sítio era de telha-vã, e pelas ripas de palmito esfiapadas, viam-se pendentes, em franjas begras, as teias de aranha e os picumans, grossos como pó de café, baloiçantes ao impulso da fumaça que subia do meio da sala, fazendo arder os olhos da gente, que era forçada a engulir em seco, um eito de tempo, até que se extinguisse a lenha verde ou molhada, que fora de cambulhada com as achas secas, entre os tacurús, onde vervia, à noite, o caldeirão de feijão, cambuquira ou serraia para a ceia.

A família estava na cidade.

Eu e a negra velha, tia Jacinta, a caseira, pesadona e cadeiruda, já de cabelos brancos, éramos os únicos na casa.

Tia Jacinta, chegando fogo, endireitando os tições, acendeu o pito de barro enegrecido, fixo num canudo de dois palmos, deixou-lhe em cima a brasa que pegara com os dedos grossos e calejados, e pôs-se a contar histórias de "dante", como quem falava sozinha, a olhar para o fogo e cuspir para o lado:

- Ah! tempo!... Gente sofria... Ante de seu avô me comprá eu, fui de ua sinhá braba que nem cassununga... A povre, que Deus tenha em bom lugá! Quando era de noitinha, ela chamava os escravo. la tudo, na sala grande, rezá. Oratório aberto, nóis tudo de joeio, Sinhá sentava na frente e principiava:

- Bamo rezá ua ave-maria por arma de Tomázia.

E nóis ia rezano e Sinhá, no meio da reza, garrava chingá nóis:

"Ave-Maria... cheia de graça, (aquela que era negra bôa... dizia Sinhá...) O Sinhor é... (vocês são ua negrada ruim) convosco... (cambada de vadiu) bendita (Tomázia era bôa, vocês merece tronco) seja entre (cambada de ladrão) as mulheres (só mesmo bacaiau...) bendito é o fruito... (só o que não presta é que vive) do vosso ventre... Amen, Jezuis".

E era ansim tudo dia. Noóis rezava p'ro Sinhô e p'ros escravo morto, argua veis de judiação...

Despois os home ia simbora e nóis ficava e'os cliolinho: uns debuiando mio, otros trançano chapéu de paia e outros quebrano fejão verde.

Um dia, graás a Deus e nosso Nossinhô Jezuis Cristo, pareceu seu avô. Sua mãe inda num era casada... Era ua moça tão bunita... suas tia, meas sinhá moça, seus tiu... Seu avô tava percizando de ua maman p'ra seu tio Nho Dô, que tinha nascido; eu tava cum leite de meis... meu marido tinha sido vendido p'runs home da província de Mina... Eles cunversaro; Sinhá chamô eu:

- Jacinta!

- Sinhá! E vim lá da cuzinha.

- Vassuncristo, Sinhô! Lovado seja nossinhô J ezuis Cristo...

- Deus te abençoe.

- Amen J ezuis.

— Óia, negra... póde pegá seu fio... Vendí ocê c'o criolinho p’ra nhô Quim.

A-mó-que entrei no céu! Eu sabia que seu avô era bão... sua avó tamêm... Os escravo dele vivium gordo, bunito, forgavum, no batuque, despois da carpa e da coiêta e na moage tamém.

Cumpanhei seu avô.

Quando cheguei, sua avó me inzaminô, vê se eu num tinha firida, se eu era forte, cherô mea boca p'ra vê se eu não bebia pinga... e ficô contente. Fiquei durmindo em casa e o meu fio durmia na merma cama, ua cama maciu, limpa, c'o meu fio de 
leite, seu tiu. Eu era tratada cum leite, carne, áua de assuca... E Nhô Dô ia cresceno c'o meu fio... Era ua buniteza. Criei os dois e fiquei negra de cuzinha e p'ra serviço casêro; argua vêiz eu mandava inté in Sinhá... Quirium tão bem eu... Vestia as moça suas tia... Lavava os pé de todos... E quano nóis ia festá na cidade, era um estadão; inté saia de goma eu vistia e ficava tudo pimpona...

Neste ponto tia Jacinta se levantou, toda emproada, mãos na cintura, mexendo as cadeiras como quem marcha, e, nos seus olhos radiantes, junto ao mais doce sorriso, via-se transparecer a felicidade... O passado... o passado... e num suspiro:

- Bão tempo era aquele... eu era bunita...

As criança crescia. No sítio era ua buniteza! Nhô Dô no meio dos criolinho já aprendia brincá! E-vê que tô veno tudo:

- Tempo será!

- Se pudé me pegá!

- Galinha gorda!

- Fejão sem dá!

Despois:

- Meu cumpadre! Quantos pauzinho tem no céu?

- Vinte e um queimado!

- Quem queimô?

- Ladrão dos porco!

- Vá que se prenda?

- Bem dito, vá...

E zele tudo pegano p'ra mão ia passano imbaxo do braço do outro inté fazê ua corrente sempre cantano:

- Galin-fon-fon! Da cor do limão! De Nossa Sinhora! Da conceição...

- Meu cumpadre!

- Sinhô!

- Tem ua corda $p^{\prime}$ ra me imprestá?

- Tenho, mais ta cheia de chichica de galinha.

- Serve ansim mermo!

E tia Jacinta ria a bom de rir, batendo as mãos, num enlevo.

- Esticavam os bracinho e caium tudo no chão... O maió abria a mão inriba... os tarzinho tavum tudo de cócre...

- Quem vai p'ro céu?

Eles davum um pulo: bateu c'a cabeça na mão, ia p'ro céu, num bateu, ia p'ro inferno... Tudo quiria i no céu... P'ra Nhô Dô zele baxava bem a mão... De repente um não ascançava... E tudo in roda daquele garrava gritá dexano desinxavido e quereno chorá:

- Cuiza-ruim tem-tem! Cuiza-ruim tem-tem! Da cor de um vintém!

Bão tempo Bão tempo!

Nhô Dô já tava grandinho... De noite eu fazia pelote pr'ele passarinhá cum bodoque no laranja... Eu fazia pelote, ia pono perto do fogo, na cinza, e ia contano história... Quano eu via o povrezinho tava durmino c'a cabeça no meu colo.

O fogo deu um estalo. Tia Jacinta interrompeu as reminiscências. Deitou duas narigadas mais de sal no caldeirão; tomou a colher de pau, despejou o caldo na palma da mão amarelada e grossa; deu um estalo na língua...

- Ta quage bão...

- E depois?

- Dispois nem é bão lembrá. Sua mãe já tava casada com seu pai, esperano seu premero ermão; suas tia tavum p'ra casá; tudo casava $c^{\prime}$ os primo, só duas que não. Nhô Dô já tava aprendeno a lê c'um mestre que sinhô justo e que de noite 
insinava os criolinho tamém a lê letra de mão; eles num tinham cartía, mais aprendium.

Tia J acinta interrompeu chorosa a narrativa.

- Despois... povre de seu avô... que pecado! Um dia pego fogo no canaviá e foi tudo razo... Ele ê-vê que tava deveno $\mathrm{pr}^{\prime}$ um vizinho, um marvado, um tar capitão Fidele, um hóme ruim. Deus que perdôe ele, já morreu quezano.

Era um sinhô mau: matava negro de fome; dava capim cuzido invêis de cove co' angú... Ele tinha ua reiva de mim, morde me vê p' ra sala lidano c'as criança.

- Ah! Negra! Fosse minha!

- Sinhô se atrapaiô de ua veis c' ua jada e...

A velha tia Jacinta, erguendo o avental, enxugou os olhos razos d'água.

- Tamêm que fumacêra... num dexa nem a gente proseá...

- Que aconteceu a vovô?

- Capitão Fidele chego um dia tudo cheio de si e aperto sinhô por dois conto...

- Quero a negra Jacinta, sem o filho, e está decidido.

- Não é possível, Capitão! Escolha dois, três, quantos quiser, menos a Jacinta: é a maman de meu filho...

- Intão vamo vê com o merinho.

- Eu vô, sinhô... Graças a Deus meu fio fica...

- Quéto, negra! Ocê há de sê minha p'ra não sê vadia!

Num teve geito: fui dado por pagamento. Tudo chorava quando eu saí: sua vó teve um ataque, sua mãe e suas tia chorarum; Nhô Dô garrôna mea saia e dava ponta-pé no Capitão, chorano... inté Sinhô garro ingulí in seco e foi simbora p'ra drento pendê-pendeno...

Um grande suspiro, e tia Jacinta pôs outra brasa no pito sarrento, que roncava, aos chupões, ao tirar as fumaças, que logo subiam para o ar. Uma cuspada na cinza e continuou a velha:

- Já no caminho, tocada por diante, tomei ua reiada... premera reiada na mea vida! Num pude, garrei chorá saluçano...

- Negro não chora, diabo!

E otra reiada.

Ta pensano que eu sô aquele bocó, aquele pacova, aquele palerma?

O Capitão não me dexava nem vê meu fio... O feito era um caboclo de cabelo espetado, avô do Tonico, perfeito hoje de Câimbra, mau cumo-quê. Um dia eu tava na roça... Me botaro na inxada! Quando Nhô Dô e meu fio - o sítio era pegado - parecero lá tudo sustadinho, chorano p'ra me vê... O feitô veio e zele correro... Derdaí, povre de mim! panhava tudo o dia e me amarraro u alavanca na perna, cuc corrente, cumo se eu fosse negra fugida.

Garrei magrecê de fome, mais a minha pio agonia era a sodade. Os outro me davum notícia de sinhô veio e tudo...

Tia Jacinta arregalou os olhos, respirando com força e tomando novo alento.

Sentia-se-Ihe a vida como que voltando entre sustos. Olhou ainda ressabiada para todos os lados e baixou a voz.

- Nhô Dô me viu ua veis, quano ia passarinhano, que eu ia cumpanhada do feitô c' oa lavanca arrastano... Ah! Nhô Dô, meu fio branco que me sarvô!

Um dia eu tava carpino minduim na roça, perto do mato virge... Os ôtro tavum num taião bem longe... eu tava sozinha c'o peso nos pé... Nhô Dô saiu abaxadinho do mato e me deu ua lima grande de treis-quina... limei, limei, limei... suor tava correno... eu tava tremeno... Mandei Nhô Dô simbora... Quano eu vi tava sorta, apareceno as firida na perna...

E ainda como que assustada, num crescendo impressionante, continuou: 
- Garrei o mato... achei Nhô Dô no carreado... Carreguei ele... saí correno e mancano... Quando Sinhô seu avô e as famía me viu, foi um baruião... eu tava magra... magra!

- Pobre tia Jacinta!

- A pobre!

- Façamo-la fugir...

- Como?

- Espere...

Sinhá troxe ua rôpa véia de sinhô... Vistí ligero... truxero o cavalo lazão... botei um chapéu de paia... Sinhô me deu um pape e grito:

- $\mathrm{P}^{\prime}$ ra Campinas... Procure Antonho Bento!

O lazão levanto puêra na estrada que ia p'ra Campina... Cheguei assustada: fui na chácra do santo Antonho Bento... Ele fico c'o alimá e me mando p'ra Santo... Júlio Moriço me escondeu, e ansim eu fui trabaiano inté comprá mea liberdade. Fiquei forra. Sinhô seu avô num me forrô por não podê... E inté hoje eu moro cum mecêis... mecêis são meus fio...

E tia Jacinta apresentou-me o prato fundo com farinha, enchendo-o de caldo de feijão com cambuquira e serralha e perguntou, maternalmente:

- Tará bão de Sá?... (p. 158-165)

\section{DEUS PERDÔA...}

De um dia para outro começaram a aparecer casos de febre amarela na fidalga Campinas. Pipocavam aquí e alí, afugentando os fazendeiros para seus retiros, refúgios buscados pela população da cidade. Emigrava o povo cheio de terror, assustado, em desordem, fugindo ao vômito-negro. Carroças e carros de bois encordoavam-se pelas estradas, e o pânico dominava a cidade doente!

Só quem já assistiu a esse êxodo acabunhante de desesperados póde avaliar a confusão dos fugitivos. Vem depois a desolação geral. A cidade parece murchar após ter estado cheia de vida, alegria e saude.

Campinas fôra assolada pelo mal. Apenas alguns beneméritos médicos e governantes não abandonaram o posto, enfrentando, resolutamente, o perigo invisível e traiçoeiro que os rodeava.

E o mal crescia, apanhando de surpresa milhares de pessoas, impedindo-lhes a fuga, confundindo, no cerco, pobres e ricos.

O cordão sanitário era rigoroso. Fosse quem fosse, ninguem mais podia fugir sem a necessária quarentena, após a constatação de casos na zona.

Dentro de alguns dias estava cheio o lazareto e improvisavam-se hospitais.

Os humildes, temendo os funcionários do Serviço Sanitário, morriam, às vezes, escondidos sob as pontes e tapéras.

Nas fazendas e sítios as pessoas pareciam sentir-se isoladas do mundo, unidas, emboladas, num estreitamento de relações, como se vê a bordo de navios, em longas travessias.

Cada casebre era um oratório aberto. Orações aos milhares subiam, entre lágrimas, para os céus. Era o terror despertando crenças adormecidas...

- Ave Maria Credo! Disque na rua de baxo num escapô ninhum! Deus nos acuda!

- É verdade... O vendeiro portugueis foi bardeado c'o a famia intêra!...Aá... Maria Credo!

Eram duas pretas velhas que palestravam à porta de uma casa rica.

A negra velha, carinhosa e dedicada, é, às vezes, mais solícita no tratamento das crianças que as próprias mães. Quanto amor, quanta dedicação naqueles 
frangalhos de gente! Raça alguma tem produzido mais adoraveis 'mamans'. Sofrem, se sofremos; gozam, se gozamos. Têm sempre palavras de conforto para os ex-senhores empobrecidos, e para os 'sinhôs-moços' extravagantes e repreendidos pelos 'velhos'.

A febre colhêra, de surpresa, dois moços da nata campineira.

'Mãe-Preta' preferiria morrer queimada viva a abandonar os 'sinhôs-moços'.

Carlos e Nhonhô, na própria casa fidalga e cheia de conforto, eram tratados pelos melhores médicos, sob as vistas da preta-velha, incansavel enfermeira, que sabia resistir ao sono, não despregando do quarto dos doentes.

Quantas vezes, com cuidado extremo, tivera de levantar os doentes, na cama, amparando-os, para que não se afogassem com o vômito, na fraqueza que estavam!

Quantas vezes, ao sentí-los dormindo, se ajoelhara a um canto, rezando rezas fervorosas, rogando a salvação para seus filhos de leite!

No período mais forte da moléstia, 'Mãe-Preta' ergueu os olhos para o céu e fez uma promessa para que seus ricos patrõezinhos não morressem;

- Ai, meu Deus! Jezuis, Maria Jusé, c'oa graça do Divino Esp'rito Santo! Sarvai Nhonhô Taliba e Nhô Carro e eles hão d'i inté o çumitério, andano, cheio de grão de mio drento das butina! Sacrifício in agradecimento da sarvação por vóis!

Nhonhô era uma bôênio puro sangue. Coração nobre e alma caridosa, inteligente, era célebre pelas suas estroinices de rapaz folgazão. Carlos possuia as mesmas qualidades, mas era menos boêmio.

Após escalda-pés e rigoroso tratamento médico, foram salvos.

'Mãe-Preta' dava graças a Deus. Suas súplicas foram ouvidas e atendidas... Era preciso convencer os moços de que deviam cumprir a promessa, fazendo o sacrifício.

Eles tudo ignoravam...

Convalescença lenta, vagarosa, cuidadosa...

- Tá bão! Graças a Deus Nossinhô J ezuis Cristo, mecêis sararo.

- Já posso beber cerveja?

- Lógo, Nhonhô... lógo... Agora eu vô contá p'ra vassunceis: quano tavum muito ruim, eu fiz ua promessa e lógo miorarum...

- Uma promessa?

- E é perciso cumprí...

- Mas não prometemos nada!

- Mais eu fiz a promessa e meceis hão de cumprí, sinão Deus me castiga, póvre da negra véia...

- Mas qual foi a promessa, Mãe Preta?

- Dos dois irem daquí inté no çumitério, cum mio por drento na sola das butina, sem meia, andano...

- Livra!

- É melhor atendermos, Nhonhô... Satisfaremos a vontade da nossa boa

'Maman'...

- É issomêmo.

- Pois que seja!

Carlos foi buscar um punhado de milho e Nhonhô afundou pela cozinha, enquanto aquele, já calçado, com os grão de milho na sola dos pés, declarou estar pronto.

Nhonhô voltou amarrando os sapatos.

E lá se foram os três, rumo do cemitério.

Carlos, cortado de dor, pé-pé pela tortura, gemia arcado, encostando-se pelas paredes. Nhonhô, lampeiro, causava-Ihe admiração...

Finalmente chegaram ao portão. Carlos, suando frio, trêmulo, sacode as botinas, desgrudando das solas dos pés, sem meia os milhos que se enterravam na carne, avermelhando a pele, onde deixavam estampada a sua forma. 
Admirados ante a resistência de Nhonhô, viram-no tirar os sapatos...

- Que é isso! Essa pasta?

- Ave Maria, Nhonhô... Já se viu só que moço? É cangica!...

- Você não disse a Deus 'como era' o milho... Eu pus milho... cozido!

- Que terrive!... Num far-má; Deus perdôa... (p. 276-280)

Cornélio Pires. Scenas e paizagens da Minha terra (Musa Caipira). São Paulo, Edição da Revista do Brasil - Monteiro Lobato \&C., 1921.

\section{ABANDONADA}

Num recanto da choça esburacada,

o resto da sanzala, uma tapéra,

se contorce abatida e abandonada,

a negra-velha que só a morte espera.

Quando moça, robusta e desejada,

- como animal que emquanto prolifera

dá productos à gente afortunada -

dava filhos e braço à classe... austera.

Hoje, inutil e doente, no abandono, tem por leito uns farrapos de baixeiro onde terá seu derradero somno.

- Oh! sorte caprichosa! Oh! varia sorte!

Emquanto gosa, alegre, o fazendeiro,

solitaria a ex-escrava espera a morte! (p.18)

José Lins do Rego. Menino de Engenho. Rio de Janeiro, Livraria José Olympio Editora, $\underline{1932 / 1980 .}$

"A velha Totonha de vez em quando batia no engenho. E era um acontecimento para a meninada. Ela vivia de contar histórias de Trancoso. Pequenina e toda engelhada, tão leve que uma ventania poderia carregá-la, andava léguas e léguas a pé, de engenho a engenho, como uma edição viva das Mil e Uma Noites. Que talento ela possuía para contar as suas histórias, com um jeito admirável de falar em nome de todos os personagens! Sem nenhum dente na boca, e com uma voz que dava todos os tons às palavras.

As suas histórias para mim valiam tudo. Ela também sabia escolher o seu auditório. Não gostava de contar para o primo Silvino, porque ele se punha a tagarelar no meio das narrativas. Eu ficava calado, quieto, diante dela. Para este seu ouvinte a velha Totonha não conhecia cansaço. Repetia, contava mais, entrava por uma perna de pinto e saía por uma de pato, sempre com aquele seu sorriso de avó de gravura nos livros de história. E as suas lendas eram suas, ninguém sabia contar como ela. Havia uma nota pessoal nas modulações de sua voz e uma expressão de humanidade nos reis e nas rainhas dos seus contos. O seu Pequeno Polegar era diferente. A sua avó que engordava os meninos para comer era mais cruel que a das histórias que outros contavam.

A velha Totonha era uma grande artista para dramatizar. Ela subia e descia ao sublime sem forçar as situações, como a coisa mais natural desse mundo. Tinha uma memória de prodígio. 
(...) O que fazia a velha Totonha mais curiosa era a cor local que ela punha nos seus descritivos. Quando ela queria pintar um reino era como se estivesse falando dum engenho fabuloso. Os rios e as florestas por onde andavam seus personagens se pareciam muito com o Paraíba e a Mata do rolo. O seu Barba-Azul era um senhor de engenho de Pernambuco." (p. 49-51)

“Depois Sinhá Totonha saía para outros engenhos, e eu ficava esperando pelo dia em que ela voltasse, com as suas histórias sempre novas para mim. Porque ela possuía um pedaço do gênio que não envelhece." (p. 54)

José Lins do Rego. Meus Verdes Anos. Rio de Janeiro, Editora Nova Aguilar S.A., 1987.

"A voz da velha Totonia enchia o quarto, povoava minha imaginação de tantos gestos, de tantas festas de rei, de tantas mouras-tortas perversas. Tinha a velha um poder mágico na voz.(...) Tinha para mim um poder de maravilha tudo o que saía da boca murcha da velha Totonia." (p. 1205)

"As cenas dos encontros eram vividas pela velha Totonia com todos os tons de voz.", ou ainda, "A voz fanhosa repetia as estrofes." (p. 1239)

“Ia-se embora a velhinha boa. E me ficavam as tristezas." (p. 1240)

José Lins do Rego. Histórias da Velha Totonia. Rio de Janeiro, Livraria José Olympio Editora, 1936. s. p.

"Aos Meninos do Brasil,

Ainda me lembro hoje da velha Totonia, bem velha e bem magra, andando, de engenho a engenho, contando as suas histórias de Trancoso. Não havia menino que não Ihe quisesse um bem muito grande, que não esperasse, com o coração batendo de alegria a visita da boa velhinha, de voz tão mansa e de vontade tão fraca aos pedidos dos seus ouvintes.

Todas as velhas Totonias do Brasil se acabaram, se foram. E outras não vieram para o seu logar. Este livro escrevi pensando nellas... Pensando na sua velha Totonia de Sergipe, Sylvio Romero recolheu estas mesmas histórias que eu procuro contar aos meninos do Brasil.

Quizera que todos elles me ouvissem com a ansiedade e o prazer com que eu escutava a velha Totonia do meu engenho. vida."

Se eu tiver conseguido esse milagre, não precisarei de maior alegria para minha

Cassiano Ricardo. Martim Cererê: O Brasil dos meninos, dos poetas e dos heróis. São Paulo, Edição Saraiva, 1928/1962.

DANÇA EM VOLTA DO FOGO

São Cristo-sinhô!

que Oxalá já chegou

pra dançar na macumba;

que veio Xangô!

que a sua mucama

cabinda ou macua

chegô. 


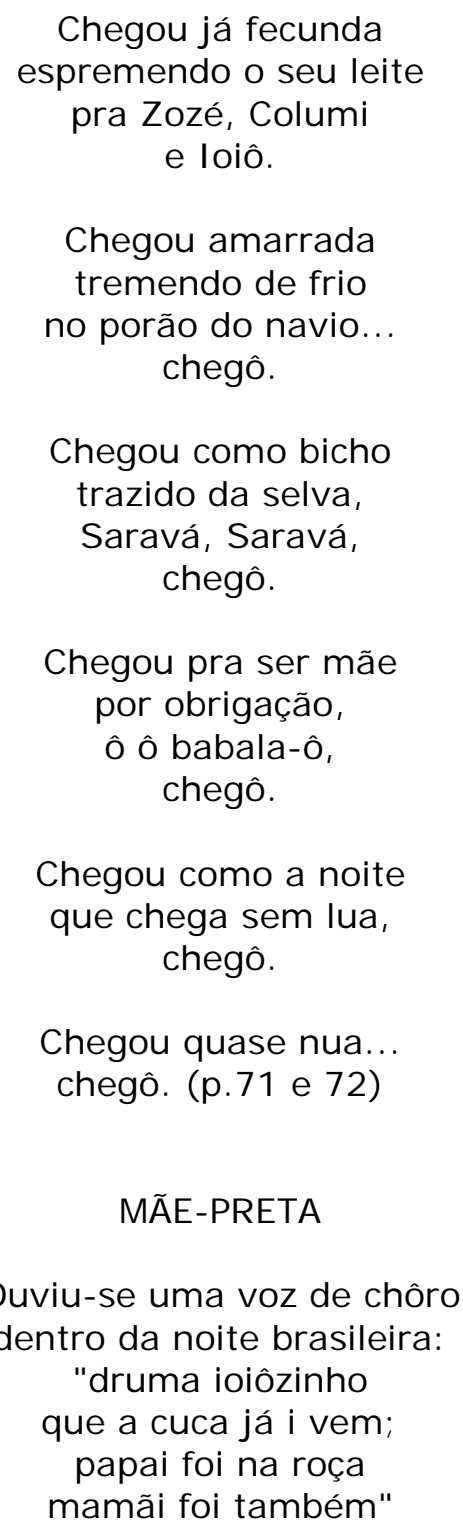

E a noite pôs, em cada sonho de criança, uma porção de lanterninhas de ouro.

E o dia era um bazar onde havia brinquedos, bolas de joá, penas de arara ou papagaio;

dia-palhaço oferecendo os seus tucanos de veludo. Árvores-carnaval que jogavam entrudo.

Cada criança, ainda em botão, chupava, ao peito de carvão de uma ama escrava,

a alva espuma de um luar gostoso tão gostoso que o pequerrucho resmungava pisca-piscando os dois olhinhos de topázio cheios de gôzo.

Parou o bate-pé dos pretos no terreiro. 
Lá fora anda a invernia assobiando, assobiando...

O céu negro quebrou a lua atrás do morro.

Quem é que está gritando por socorro?

Quem é que está fazendo êste rumor?

As fôlhas do canavial

cortam como navalhas;

por isso ao passar por elas

o vento grita de dor...

(O céu negro quebrou a lua atrás do morro)

"druma ioiôzinho que a cuca já i vem;

papai foi na roça

mamãi foi também". (p. 104 e 105)

Cassiano Ricardo. "Vamos caçar papagaios" in: Poesias Completas. Rio de Janeiro, Editora José Olympio, 1926/1957.

\section{SANGUE AFRICANO}

Ó meu Pai-J oão, por que choraste?

Olhei o negro velho, ao clarão da fogueira, e pareceu-me ver a noite em forma humana;

e pareceu-me ver a saudade africana

crucificada numa noite brasileira...

Lá fora, no terreiro da fazenda,

a dança trágica e noctâmbula dos pretos, de sarabanda em bamboleios de perna bamba

no resmungo sem fim do bumbo ou do urucungo

no arrasta-pé grosseiro e fúnebre do samba

que retumba na noite lúgubre que descamba:

é o chôro surdo e entrecortado do batuque,

no pate-pé que enche de assombro o próprio chão...

E a lua alvíssima derramada na restinga

pinta cal tôda a paisagem de carvão;

nas casas de sapé, nas moitas de caatinga,

pinga na sombra qualquer coisa de mandinga

e assombração.

Ó meu Pai-J oão, eu sei de tôda a tua história.

Quando o navio alçou o pano ao vento da África,

algemaram-te as mãos em cadeias de chumbo;

e, no porão, olhando os astros, noite em fora,

quanta vez escutaste o longínquo retumbo

do oceano a estrangular as praias sem aurora

como um negro quebrando as cadeias de chumbo!

Depois... os cafezais, os eitos, ó contraste!

Por entre moitas, espraiados e barrancas,

baixou a noite dos cativos e ficaste 
crucificado numa cruz de estrelas brancas!

Depois, fugiste ao cativeiro;

fundaste, à sombra dos palmares, tua cidade livre, e com o teu próprio sangue semeaste a redenção do solo brasileiro.

Depois... a tua redenção.

Depois que as tuas lágrimas

já se haviam juntado ao nosso coração;

e que o teu sangue já se havia derramado

nas raízes da raça enterradas no chão...

Tu tens razão... tu tens razão.

Não há nada que mais me oprima ou me machuque

o coração de brasileiro, ó meu Pai-João,

do que ouvir, pela noite negra, que foi sempre

a doce mãe dos pretos sem história, com seu leite luar e o seu luto de glória,

ouvir o chôro surdo, sapateado e entrecortado do batuque.

Ó meu Pai-João, por que choraste?

E êle nem me voltou o rosto de carvão.

Como um grito de dor, dentro do coração,

pareceu-Ihe escutar o clamor da senzala.

E grandes lágrimas de opala

Ihe estrelaram a face negra, à hora do jongo,

como se o pobre prêto, em sua noite escura,

conseguisse acender as estrêlas do Congo... (p.72 e 73).

Coelho Neto apud João do Rio. O Momento Literário. Rio de Janeiro, Fundação Biblioteca Nacional, 1994.

\section{ENTREVISTA COM COELHO NETO}

- Para a minha formação literária, começa ele, não contribuíram autores, contribuíram pessoas. Até hoje sofro a influência do primeiro período da minha vida no sertão. Foram as histórias, as lendas, os contos ouvidos em criança, histórias de negros cheias de pavores, lendas de caboclos palpitando encantamentos, contos de homens brancos, a fantasia do sol, o perfume das florestas, o sonho dos civilizados... Nunca mais essa mistura de ideais e de raças deixou de predominar, e até hoje se faz sentir no meu ecletismo. A minha fantasia é o resultado da alma dos negros, dos caboclos e dos brancos. É do choque permanente entre esse fundo complexo e a cultura literária que decorre toda a minha obra, e daí Baladilhas, Rapsódias, livros de uma fatura absolutamente especial. (p. 53-54) 
Sílvio Romero apud João do Rio. O Momento Literário. Rio de Janeiro, Fundação Biblioteca Nacional, 1994.

\section{ENTREVISTA COM SILVIO ROMERO}

“Como caráter de temperamento, sou hoje o que era aos cinco anos de idade. (...) Eu tinha seis semanas. Fui transportado para o engenho de meus avós maternos a quatro léguas de distância, na região chamada o Piauí, de um rio deste nome que ali corre águas turvas e cortadas no tempo das secas. O sítio era delicioso, com trechos de mata virgem, belos outeiros fronteiriços, riachos correntes e o engenho. Este era dos de animais. (...) Fiquei no engenho Moreira, tal é sua denominação, até os cinco anos. Dos três em diante a moagem era para mim um encanto. (...) Tudo que sinto do povo brasileiro, todo meu brasileirismo, todo meu nativismo vem principalmente daí. Nunca mais o pude arrancar d'alma, por mais que depois viesse a conhecer os defeitos de nossa gente, que são também meus defeitos. Outra coisa que me ficou incrustada no espírito, e com tanta tenacidade que nunca mais houve crítica ou ciência que dali ma extirpasse: a religião. Ainda hoje existe, nonagenária, no Lagarto, ao lado de mim mãe, essa adorada Antônia, a quem me costumei a chamar também de mãe. É um dos meus ídolos, dos mais recatados e queridos. Nunca vi criatura tão meiga rezar tanto. Dormia comigo no mesmo quarto, e, quando, por alta noite, eu acordava, lá estava ela de joelhos... rezando..." (p. 40-42)

Wilson W. Rodrigues. Pai João Menino. Rio de Janeiro, Arca Editora, 1945/1949. $3^{\text {a }}$ Edição.

\section{O MENINO MAGRO}

Com o menino no regaço, a escrava dizia:

- Mama, meu filho, mama. Eu escondi leite para te dar. Ioiôzinho branco quer tudo para êle, mas êsse leite que guardo no meu peito foi Nosso Senhor quem me deu para te dar. Mama, meu filho, mama...

Nesse momento, veio correndo o mulato Pemba, e avisou a escrava:

- Dona Sinhá mandou dizer que menino branco está com fome.

- Mama, meu filho.

- Anda, desavergonhada. Olha que eu vou dizer.

- Vá logo, marvado.

E a escrava, medrosa, ajeitando o filho entre os panos da catre de couro, saiu correndo para a Casa Grande. O Pemba olhou o menino, e como não sabia ter piedade de ninguém, disse indiferente:

- Ih! Até se vê os ossos.

Nesse tempo de Pai J oão menino, êle era magro, magrinho, bem magrinho. A pele parecia uma túnica pegada aos ossos. (p. 7)

\section{A CATAPORA}

- Você merecia apanhar mais, negra atrevida, falou D. Sinhá com as mãos nas cadeiras. Para outra vez, não sou eu quem Ihe dá, não; eu mando o Damião Ihe meter o relho. Então, você se atreve a não querer dar de mamar ao seu patrão, ama maldita?

- É que ioiôzinho está com catapora, e o meu filho... está bom.

- Que bom, nada. Quem pegou catapora no menino foram vocês. Foi você quem trouxe a mazela da senzala. 
I oiôzinho no berço choramingava, e D. Sinhá segurando-o nos braços roliços, levou-o ao regaço da negra.

- Anda, atrevida, dá de mamar ao menino.

- Mama, ioiô.

E num tom mais baixo:

- Como seu rosto até parece moita de catapora. (p. 8)

\section{PRESENTE}

Quando a escrava entrou na senzala, o negrinho chorava:

- Está com fome

Colocou-o no regaço, repuxou o seio, deu de mamar. uma moléstia.

- Meu filho, hoje não te dou apenas leite. Dou mais. Muito mais. Dou também

\section{REVELAÇÃO}

Às vezes, à noite, a negra-mãe cantava para adormecer o menino:

Tutu Marambaia

não venha mais cá,

o pai do menino

te manda matar.

Tutu, bicho feio,

acima do teiado,

deixa o meu menino

drumi sossegado.

E tantas vezes cantou que, um dia, o menino teve vontade de conhecer o Tutu. Quando a mãe se retira, o moleque abre os olhos, espreita para ver se está sozinho, levanta-se da esteira, vai até a janela da senzala, e chama:

- Tutu Marambaia... Tutu.

Logo depois, Tutu aparece:

- Não tens mêdo de mim, menino?

- Não, Tutu. Eu quero ser seu amigo.

- Como és valente, meu amigo será.

- Tutu, por que você mora em cima dos telhados?

- Porque eu gosto de ouvir as mães cantarem.

- É bonita a cantiga?

- A cantiga das mães é sempre bela, mesmo quando elas cantam com os olhos rasos d'água.

- E minha mãe, Tutu? Por que chora quando canta?

- Chora pela escravidão, negrinho, e canta pelo dia em que no mundo não houver mais escravos. (p. 8-10)

\section{CONSOLAÇÃO}

O moleque veio correndo para o curral ver o bezerro berrar. O Tião ordenhava a Botija, a vaca mais leiteira da fazenda. O bezerro fazia alarido.

- Ó menino - gritou Tião - faz o bezerro calar.

O negrinho pulou a cêrca e veio para junto do bezerro:

- Não chore, não. Comigo êles também fizeram assim, tiravam o leite da mamãe para o ioiô branco.

O bezerro parou de chorar como se entendesse as palavras do menino. (p. 11) 


\section{POBREZA}

- Você é pobre, sim, disse o primo de ioiôzinho para o moleque J oão. eu faço.

- Não sei por quê. Eu brinco tanto com ioiôzinho e êle até tem inveja do que

- Mas você é pobre.

- Não sou.

- Ioiôzinho usa sapato e você anda de pé no chão.

Pai João menino sorriu:

- Sapato não é riqueza, nada.

- Então que é?

- O que ioiôzinho tem não é riqueza, não. O que êle tem é medo de pisar a terra... (p. 66)

\section{PRIMEIRO LEITE}

Tia Zacuta ficou desesperada quando soube que iam arrancar-lhe as mamas. Diziam que estavam cancerosas e que aquilo pegava... Chorou, pediu, suplicou, mas nem Sinhô nem D. Sinhá ouviram as suas súplicas.

- Desalmados, dizia para si mesma a velha mucama, nem se lembram que fui eu que amamentei os seus filhos. (p. 121)

\section{SETE PINGOS DE LUAR}

Na véspera de ser operada, tia Zacuta, de noite, quando todos dormiam, atravessou o terreiro e chegou à beira do barranco alto.

- Todos, agora, têm nojo das minhas mamas. Vão arrancá-las. Mas eu ainda

E, botando os grandes seios cancerosos para fora, apertou-os, espremendo-os. Caíram apenas sete gotas de leite.

- É o que me resta.

Zacuta voltou para a casa grande. E as sete gotas de leite que escorreram pelo barranco se desfizeram com o luar. (p. 123)

Luiz Delfino dos Santos. Poesia Completa. Florianópolis, Academia Catarinense de Letras, 2001. Tomo I, (escrito entre 1844 e 1910).

\section{A PRETA DA CABANA}

Esta preta que vês junto à cabana,

Velha, gasta, pedindo-te uma esmola,

Teve na terra benfazeja a escola

Do trabalho, do amor, da luta humana.

Deixou a pátria tórrida africana

Pelo Brasil, onde é soberba a flora;

$E$, no país em que ela é livre agora,

Viveu escrava e a um tempo soberana.

Misturou o seu sangue ao nosso sangue,

O seu suor, no campo, ao suor da aurora,

Deu força e alento ao nosso corpo langue. 
Helena, inda hoje embala-nos nas sestas, Como ria no lar conosco outrora

E eram suas também as nossas festas... (p. 466)

\section{A TERESA}

Teresa! E este sagrado nome é um grito Que a alma toda atravessa, e o pensamento, E o oceano em luta, e a vaga atrás do vento, E a sombra vasta e longa de infinito;

Tudo enche. - Ergo-Ihe um templo de granito, Um panteão eterno, um monumento, Que eu só vejo ir subindo, e cabo, e atento A mole abraço, e o olhar na escrava fito.

É dela. - Luz-me em resplendor de Santa: Viu-me nascer, e amou-me de maneira Que em mim criou o amor, que o amor levanta;

Dela a saudade, em minha vida inteira, Como uma árvore, acesa em ninhos, canta, E, como um vale aberto em flores, cheira. (p. 336)

\section{OS DIABRETES DE D. ANA}

Quem não teve entre os seus uma velha africana, Que embala o berço, e canta, e acarinha, e vigia? Que com histórias, que valem pérolas, grana Quimeras de oiro, e as lanças em nossa fantasia?

A nossa tinha atrás do morro uma cabana, Vegetando agarrada à bronca penedia; Junto dela o moital, no moital a alegria De uma água que cantava ao ver chegar D. Ana.

Dizia a água a saltar: - a D. Ana já veio!...

E à meia noite a velha, o rosário no seio, Feito o sinal da cruz, ia a ponte espiar.

Riam-lhe da água então grupos de diabretes, Davam pulos no ar, jogavam-Ihes barretes...

Lindos!... feitos de prata, em nesgas do luar! (p. 340)

\section{A BENEDITA E A GEORGINA}

Bendita sejas tu, mulher escrava, Bendita sejas tu, bendita sejas,

Mais santa do que a santa das igrejas, Em que o olhar indiferente a turba crava.

Alma feita de lírios, fogo e lava, 
Há Édens onde quer que vás e estejas;

Em cada beijo um rouxinol cantava,

E inda hoje canta ao crer que inda hoje a beijas.

Só teu heroísmo pôde-me salvá-la:

Que berço a voz que busca adormecê-la!

Que ninho a mão de ônix que ao berço a embala.

E há uma estrela que sorri, estrela,

Que, enquanto ela de ti me encanta e fala,

Parece-me ser tu a ouvi-la e a vê-la. (p. 340)

Luiz Delfino dos Santos. Poesia Completa. Florianópolis, Academia Catarinense de Letras, 2001. Tomo II.

O PAI JOSÉ

Era um pretinho velho o bom do escravo,

Mas velho, como era,

Vinha-Ihe da alma exalação perene

Da eterna primavera.

Não conhecia o peso das algemas:

Sua alma era a piedade,

Suspiro às vezes triste e involuntário

De mágoa e de saudade.

Por entre fachos aurorais, às vezes

Num olhar fundo e longo,

Via fugir outeiros, vales, campos.

Choças, e enfim o Congo.

Fumo...visão...saudades!...Em torno estava

Loura, chilreante e bela

A matinosa multidão, enquanto

Mexia a panela.

Era o rei da cozinha; e a dominava

Com nobre desempenho:

Que ondulante fumaça enovelava

O seu cheiroso reino!

Tinha aquele portento nas mãos negras

A mágica vergasta:

Com a colher, dizia a um, e a outro:

Nhonhô, afasta....afasta...

Fingimos fome... No país das fadas

Não há melhor cozinha:

Não cheira tanto, como estou lembrado,

Que ali cheirava a minha. 
E o pai J osé, mostrando que ralhava, Inda fidelidade

Guardada à nossa mãe, lá vinha um prato, Com grande hilaridade

Recebido por nós: estas delícias,

Da vida ornato e enfeite,

Ele nos dava, como a aurora aos montes

Mel oiro e branco leite.

E aqui jaz nesta rasa sepultura,

Sem pedra e sem letreiro,

O bom amigo, o pai José, o escravo...

O nosso cozinheiro!

Flores de gratidão derramo agora

Onde ele está sepulto:

São verdadeiras lágrimas, que choro

Sobre este chão inculto.

Ai! quando ele morreu, não levou tudo

Para a cova consigo:

Ai! que saudades nos deixou o negro...

O nosso pobre amigo!...

Sob essa crosta bárbara e sombria, Que eterna primavera,

Que alma cheia de luz e de perfumes Lá dentro não coubera!...

Quando, para estudar, da loira turba

Algum de nós fugia,

Emigrando, qual prófuga andorinha,

Que tristeza o invadia...

Chorava... Até que um dia já de volta

Chegava o senhor-moço...

Era um dançar de louco, em torno dele,

Um curvar de pescoço,

Bater de palmas, dar com os pés em terra, $\mathrm{E}$ a tudo, que ele via,

Ao céu, ao sol, aos muros, e arvoredos A bênção ele pedia.

Já Ihe caíam lágrimas dos olhos,

Já ria, já gritava:

Era um vulcão, que a luz de mil auroras

Num instante entornava!

Veio a morte um de nós buscar um dia, Que grandes gritos doudos!

Parecia chorar pelo universo, 
Por si, e por nós todos!...

A dor profunda Ihe abalava a entranha:

Ele a mostrava em tudo:

Chorava a dor, nas lágrimas chorava,

Chorava-a o lábio mudo.

Adeus, meu pobre preto, adeus! - Contigo

Minha infância querida

Dorme também da mesma relva à sombra,

Que te cobre a jazida.

Esta saudade adorne-te o sepulcro,

Porta da liberdade:

Ninguém ossário encheu de amor tão grande,

E tão grande piedade!... (p. 268-271)

Hélio Serejo. Mãe Preta - Poema. São Paulo, s.d. - Coleção Balaio de Bugre. Vol.5

MÃE PRETA

“MÃE PRETA NASCEU ALI,

BEM JUNTICO DA INVERNADA

NO RAIR DA MADRUGADA!

NASCEU COM O CANTAR DOS GALOS, COM O RELINCHAR DOS CAVALOS;

NASCEU NUM GALPÃO RELVOSO, ONDE, A GALOPE, TEIMOSO,

SOPRAVA O VENTO NASCENTE

GELANDO A CARNE DA GENTE!

MÃE PRETA NASCEU ALI,

E NASCEU, PRA NA VIVÊNCIA, DA SUA PRÓPRIA QUERÊNCIA,

OLHAR O AZUL INFINITO,

PRA CRAVAR, NO CHÃO BENDITO,

O MARCO DA SUA EXISTÊNCIA,

QUE SERIA, NA INCLEMÊNCIA,

- PROSEADA DE GALPÃO,

— REFUGO DA TRADIÇÃO!

POBRE MÃE PRETA! MULAMBO!

CORPO DORIDO... SURRADO, 
FOGO DE CHÃO APAGADO!

MÃE PRETA, PRAGA ROGADA,

NA NOTE SEM ALVORADA;

— FIGURA TRISTE, ANDEJ ANTE,

- ALMA SOFRIDA... ROGANTE

- COURO ATIRADO AO RELENTO,

- IMAGEM DO SOFRI MENTO!...

QUE DESTINO INGRATO O TEU!

QUE SORTE MAULA ESSA TUA!

POIS NEM O CLARÃO DA LUA,

A RENDILHAR O DESERTO, APOIOU TEU PASSO INCERTO,

POIS TU, NA GRANDE J ORNADA, DEIXASTE PELAS ESTRADAS, COM A DESCRENÇA E O PERDÃO,

QUASE CEGA... ENCARQUILHADA, TRAZENDO DENTRO DO PEITO

TODOS OS SONHOS DESFEITOS,

- GOLPEANDO A EVOCAÇÃO,

- NA MANGA DA I NGRATIDÃO!...

- PEDAÇOS DO CORAÇÃO!... POBRE MÃE PRETA, COITADA!

ENRUGADINHA E SUMIDA,

LEMBRANDO OS FATOS DA VIDA, VIVE NUM CANTO JOGADA!

QUE PÊRRA LUTA, MÃE PRETA!

— QUE PIALAÇO TÃO FERINO,

— QUE BRAVEZA DE DESTINO!...

SORTE MAULA... DESGRAÇADA, MÃE PRETA DESFIGURADA,

CUÊ-PUCHA, BARBARIDADE! FOSTE CARINHO E VERDADE,

ENTRETANTO, NA AGONIA, ÉS MÃE PRETA, SEM VALIA!... TU ÉS FIGURA DE LENDA, 
ÉS SOMBRA QUE O VENTO AFRONTA, HISTÓRIA QUE A HISTÓRIA CONTA,

ENTREVERANDO A CHULICE,

E NO PIALO DA VELHICE!

TU ÉS ALMA PENADA

QUE VAGUEIA PELA ESTRADA

- A TANGER, PELA PLANEIRA,

- A TROPA DA DESVENTURA!

AGORA... TU ÉS BAGAÇO!

ÉS UM TRASTE NA PORFÍA,

POIS CAÍSTE, NA PORFÍA,

DE GOLPE, DE TRANCO EM TRANCO,

NA COR DOS CABELOS BRANCOS!

TU ÉS A SOMBRA MALDITA,

TU ÉS A MÃE PRETA AFLITA,

TU ÉS UM GUAXO ENJ EITADO,

PASTOREJ ANDO O PASSADO!...

MÃE PRETA! QUE EU ME REVOLTO;

VENDO TU, QUEBRADA E GASTA, POR UMA SINA MADRASTA!

VENDO TU, PALANQUEADA;

NA SUPREMA VOLTEADA,

ABICHORNADA NUM CANTO,

A VERTER O AMARGO PRANTO, NO MAIS CRUEL DOS BOLEIOS,

DO TEU ÚLTIMO RODEIO...

MÃE PRETA SANTIFICADA!

MÃE PRETA CHEIA DE GLÓRIAS,

SÃO SUBSÍDIOS PARA A HISTÓRIA!

MÃE PRETA QUE CHORA E CANTA,

- IMAGEM DA PÁTRIA SANTA!...

MÃE PRETA MARTIRIZADA,

PELA VIDA AOS SOLAVANCOS 
- SOB ESTE CÉU DE COR ANIL, MÃE PRETA CRIANDO BRANCOS,

E, DE J OELHOS, CONTRITA,

PEDINDO A VIRGEM BENDITA,

PAZ E AMOR PARA O BRASIL".

Luiz Demétrio Juvenal Tavares. Serões da Mãe Preta. Belém, Secretaria de Estado da Cultura/Fundação Cultural do Pará Tancredo Neves, 1890/1990.

\section{MÃE PRETA}

"No Pará e Amazonas, a 'mãe preta' é um tipo legendário criado pela escravatura. Não sei se no Sul apareceu igual personagem: o que sei, o que todos sabem, pelos tristes fatos da escravatura no Brasil, é que o escravo do Pará e Amazonas em nada era comparável com o do Sul.

Ali o negro era considerado, não como um homem, mas como uma besta de carga, uma simples máquina feita para o trabalho material e meio de enriquecer o branco.

Para ele havia a senzala, coisa desconhecida entre nós; o 'bacalháo' e outros suplícios infamantes, instrumentos cruéis com que o seviciavam e o levavam à mesma estiva com os animais irracionais.

Aqui, não. O escravo era tratado como um membro da família, guardando-se apenas a distinção que naturalmente existe entre o criado e o patrão.

As mulatinhas eram criadas com as meninas, com quem iam à missa e aos passeios, com suas chinelinhas de polimento e tacão alto, com rosários de ouro, etc. família.

Eram tratadas com recato e dormiam no mesmo quarto em que dormia a

A dona da casa, a branca, ou a 'mãe tinga', como a chamavam as rapariguinhas, concentrava em si o supremo poder do lar.

Mas havia um outro ente, outra autoridade no estudo doméstico, igualmente respeitável, que partilhava com ela esse poder: - era a 'mãe preta', ordinariamente uma mulata velha, séria e bondosa, que tinha a grave incumbência de criar todos os meninos da 'sinhára'.

Oh! quantas recordações docemente saudosas, não nos traz este ente querido, em cujo 'colo' íamos para o banho, a cuja narração de historietas inverossímeis passávamos as horas agradáveis do serão, a cuja voz, cantando o 'ninã-ninã' ou o 'murucutu empresta o teu sono', adormecíamos em nossa redinha de fio de algodão!...

A 'mãe preta' tomava a si o cuidado especial e carinhoso de dar aos meninos todo o bom tratamento que Ihes convinha, asseiando-os com especial dedicação.

À noite, rodeada das crianças, embaixo de uma grande candeia de barro alimentada com azeite de andiroba, ela Ihes contava alegres e divertidas histórias.

Se fossemos poeta de gênio, em vez desta singela notícia, consagraríamos um poema a essa personalidade da 'mãe preta', cuja imagem sempre querida, guardamos no peito, cuja recordação perdura em nossa memória, em traços indeléveis.

“Na impossibilidade, porém, de cometermos tão transcendental trabalho, apresentamos este livrinho, em que se procura copiar com verdade os 'contos da mãe preta'." (p. 20-21) 
"A Mãe Preta, no meio das crianças, ansiosas e atentas, sentadas todas sobre o grande tupé de talas de muruti, começa sua narração." (p. 22)

“Quando a Mãe Preta, depois da ceia, disse que no serão dessa noite ela ia contar as histórias de um famoso Papagaio, os meninos acercaram-se dela com mais atenção e interesse. narração.

- Ora a Rosa!... disse um dos meninos, já sequioso, por ouvir o começo da

- E era mesmo Rosa que esse tratante se chamava, acudiu ela.

E começou a narrar as proezas seguintes. " (p. 27)

"Seus olhos pequeninos [do jabuti] estão sempre cheios de lágrimas; mas ninguém acredite naquelas lágrimas... Aquilo é manha para enganar os outros animais, como uma vez ele já passou a perna no veado.

Ao ouvir isto, deram uma forte gargalhada as crianças.

'Ah! vocês duvidam? - disse a Mãe Preta, - pois ouçam'.

E contou a história seguinte." (p. 22)

"Quando mãe Preta disse que o Jaboti havia morto uma Onça, houve entre a criançada uma verdadeira algazarra.

- Ah! vocês duvidam? Pois escutem, disse ela.

E começou a história." (p. 23)

"A mãe Preta piscando o olho esquerdo, como quem diz: - 'agora eles vão ficar atrapalhados para responder-me', - perguntou:

- Vocês sabem porque o casco do Jaboti é todo emendado em pedacinhos?

- Não, senhora, não sabemos, bradaram os meninos.

- Pois eu Ihes digo." ( p. 25)

"Só há no mato um pau que ele [o jaboti] não quer que venha sobre suas costas; e por isso, quando pressente alguma trovoada, foge bem longe do tal pau.

- Qual é? Perguntaram os meninos.

- É o taperebazeiro, ou cajazeiro, como denominam em outros estados.

- E por que tem ele medo do taperebazeiro?

- Porque essa árvore é carne de cão.

- Ah! é carne de cão... então não morre...

- Não ela cai no chão e torna a grelar por toda a extensão que fica sobre a terra.

Por isso, quando um Jaboti sente um taperebazeirono seu costado, ele perde a esperança de viver e trata logo de fazer seu testamento e encomendar a alma a Deus.

Vamos ao caso." (p. 23-24)

"Mãe Preta começou assim:

De todos os bichos do mato que a gente cria em casa para seu divertimento, o macaco é o que mais amizade dedica.

Uma vez criado em casa nunca mais foge para o mato; e se ele o fizesse, estava arriscado a morrer de fome; porque macaco é vadio; ele não fala para não trabalhar.

- E porque - disse um menino - e porque o Chico vive todo o dia a gritar, a pular no cepo, querendo arrebentar a corda?

- Ah! não o sabem? É por causa da sede.

- Então é por isso que ele mija nas mãos e bebe, acudiu um menino travesso.

- É por isso mesmo - confirmou a Mãe Preta. 
E contou a história seguinte:" (p.32)

"Por que razão, perguntou a Mãe Preta, tapuio não mata mutuca?

- Então tapuio não mata mutuca, perguntou por seu turno e muito admirado, o pequeno Eduardo.

- Não mata, não.

- Ora essa! E quando a mutuca ferra a gente, com aquele ferrão que tanto dói, não deve se matar a mutuca?

- Nunca, e eu Ihes digo porquê.

(...)

De sorte que o prudente tapuio, temendo ser azoinado e atormentado por milhões de mutucas, prefere não matar a primeira que lhe vem martelar os ouvidos e sugar-lhe o sangue.

- E o que faz ele para ver-se livre de tão insuportável inseto?

- Ele só diz-Ihe: vai com quem te mandou! Vai com quem te mandou! - e ela se retira zunindo como um pião." (p. 34)

"Como era negociante de papagaios, serviu-se de Rosa para fazer dela o chama.

- O que é chama? Interrogou a sagaz Anica.

- É o chamariz, respondeu a Mãe Preta.

- E o que é chamariz? Perguntou Luizinha. essa noite!

- Mau, mau! Resmungou a mulata velha; vocês já querem ficar sem história

- Não! Não! Isso não! Berraram os outros.

Então ela explicou: - é o que vocês aqui, quando querem pegar o Tem-tem, prendem no alçapão.

- Ah! fizeram todos em coro; é a negaça...

- Pois bem, eu vou continuar:" (p. 29)

"Mas o diabo era linguarudo como um barbeiro! Aquela língua seca não parava. Falava nomes porcos e obscenos...

- O que é obsceno? Interrogou o J oãozinho, com curiosidade.

- É palavra que os meninos não devem saber nem dizer, disse a Mãe Preta um pouco contrariada. E ninguém me faça mais perguntas.

Dado este cavaco, continuou:" (p. 31)

"Hoje, - disse a Mãe Preta com tristeza, quando chegou a hora do serão, vamos ler uns pequenos romances, cujo autor se ocupa em narrar os desastres de alguns desses amigos domésticos, que nos servem em casa, de utilidade e divertimento: são o cão, o gato, o passarinho, o galo, a galinha, etc., etc.

- E os ratos também, disse Anica. prejudicial.

- Nada disso, respondeu Mãe Preta: esse é um companheiro intruso e muito

Em seguida, tirando do bolso um livrinho, abriu-o e o deu a ler ao menino mais velho, que logo começou a leitura, indo ela notando os erros que cometia." ( p. 34-35)

"Bom; gostei muito de ouvir a leitura dos amigos mortos; e, porque ela foi bem feita, vou dar-Ihes um prêmio; disse Mãe Preta.

- Que será? Perguntaram os meninos.

- É a história do bicho folharal...

- Bravo! Bradaram em coro; venha o tão desejado bicho folharal.

E ela começou a narrar." (p. 51) 
"A memória, disse Mãe Preta, é uma faculdade que se adquire. Um menino desmemoriado, ou esquecido, como se diz, pode depois conseguir decorar tudo que ler ou ouvir, com maior facilidade, exercitando a memória. Nada mais eficaz para isso, do que decorar versos.

Em seguida fez os meninos lerem e cantarem versos simples e de fácil audição." (p.56)

Maria Alves Velloso. As férias com a vovó. Rio de Janeiro, Livraria Francisco Alves, 1932.

\section{DIA DA GOIABADA}

Uma das coisas que os pequenos mais gostavam, era o dia da Goiabada.

Certa manhã, passando pela cozinha elles viram Jovita de avental de riscado com um tacho de cobre nas mãos. Signaes certos de que havia goiabada pela zona!...

O' J ovita! Disse Stella. Você quer que a gente ajude a fazer goiabada; quer?

J ovita - É, eu bem sei o que vocês querem, seus interesseiros!

Tiz - Não é não! A gente gosta mais de passar goiabada na peneira do que de comer. Agora!...

Pois é, disse Zoe.

Jovita - Então vamos, gente, vamos! Ué! Porque é que está tudo ahi parado? Peguem nas vasilhas, nas peneiras, e vamos! Vamos p'ro quintal!

Isso mesmo é que os pequenos queriam. Cada um agarrou o que poude, e com muito cuidado para não zangar J ovita, lá foram todos para fóra. Sentaram-se em baixo de uma jaboticabeira, e toca, mãos a obra! Uns tiravam os caroços, outros passavam na peneira. Trabalharam, trabalharam até a hora do almoço. Jovita que tinha ido para dentro, voltou dali a pouco com uma latas e forminhas na mão. Marcello, que doidinho de gulodice, perguntou logo: O' J ovita! Isso é p'ra gente, é?

Jovita - Que p'ra gente nada; ué! Vocês não disseram que só gostavam de peneirar goiabada! Pois então!

E a velha riu-se.

Os outros, que já conheciam o systema, não disseram nada. no tanque, vá!

Jovita - É hora do almoço, hein! Sinházinha já está na sala. Vá tudo se lavar ali

Tiz - Você inda quer que a gente ajude depois do almoço, quer?

doce.

Jovita - Eh! Eh! Depois do almoço, eu quero mais é socego para mexer meu

Stella - Olhe, você querendo eu sei mexer muito bem. Não queimo, não!

Jovita - Deus me livre! O’ crianças! Sinházinha está chamando, gente!

O pessoal correu para a casa, mas, depois do almoço, o dia inteiro, ninguem sahiu do quintal: ora um, ora outro, andava por perto da joboticabeira, assim com uns ares disfarçados, só para ver o que fazia a velha. E ella lá estava com um panno amarado à cabeça por causa do sol, mexendo o doce com uma pá muito grande. Afinal, lá pela tardinha, a goiabada ficou prompta, e Jovita começou a encher uma porção de latas. Depois tomou as forminhas que trouxera, e encheu-as tambem. Tiz, que andava passeando à espreita, correu chamando os outros.

É hora, pessoal! Ella já está enchendo as nossas latas.

E a taes palavras, Jovita começou tambem a gritar: o' crianças! crianças!

Que é? Responderam ellas, já prevenidas, pondo-se a correr.

Olhem, disse a preta, entregando-Ihes as latas; tratem de lamber isso depressa que eu vou raspar o tacho.

Os pequenos agarraram as forminhas sentaram-se no chão e regalaram-se de goiabada quente! Que delicia! Jovita sentou-se tambem e fez companhia às crianças. 
Depois da goiabada prompta, a mulata ficava sempre de bom humor. Os pequenos já o tinham percebido, e, como gostavam de ouvir falar a velha, aproveitavam sempre essa occasião.

O' J ovita, disse Stella; é verdade que o doce desanda quando a gente conversa emquanto está mexendo?

Jovita - É, sim! Até perigoso.

Tiz - Porque é, hein?

J ovita - Porque, sabe, não é? Anda tanto feitiço pelo ar; e, a gente distrahida, cae o feitiço no doce... e prompto!

Zoé - Ah! então é por isso que você não quer ninguém aqui?

Jovita - É; me lembro daquella negrinha que ficou sempre enfeitiçada.

Ruth - Que negrinha? Como foi, hein?

Jovita - Ah! Isso já foi ha muito tempo! Eu era pequena.

Marcello - I h! Então foi mesmo ha muito tempo!

Jovita - Pois é! Não havia ninguem como aquella creoulinha p'ra fazer os doces. Era cada bananada gostosa - cada goiabada vermelhinha, sempre no ponto! Um dia a pequena estava mexendo a goiabada, quando passou uma borboleta azul.

Marcello - Como as que têm no matto, não é?

Jovita - Assim mesmo. Pois a pequena ficou doida pela borboleta e começou a falar com o moleque que estava ali perto. "Ah! Eu quero aquella borboleta! Eu quero! Vae apanha-la para mim, Vicente! Ah! Borboleta, espera um pouco, espera!" E o bicho parece de propósito, só esvoaçava em volta da negrinha. Quando esta quis pega-lo, elle fugiu de vez; mas a pequena não acertou mais o ponto do doce. Não houve meio! Estragou um talho enorme. Aquillo era algum encanto, que andava voando para ella ficar tentada! Eu sei que nunca mais a pretinha acertou os doces. Cada vez era uma tachada desperdiçada, e os senhores brigavam que nem era vida.

Ora, disse Adolpho, você não vê logo que ella deixava passar do ponto o doce e que só por isso queimava?!

J ovita - Credo, menino! Você não acredita em nada! Pois eu me lembro d'essa pequena; ella chorava que fazia pena, dizia que a borboleta tinha vindo botar quebranto n'ella.

Adolpho não quis brigar com a velha e calou-se; as meninas piscaram um olho e abafaram uma risadinha, mas Vera e Marcello estavam um tanto assombrados.

Vera - o J ovita, ainda ha encantos?

Jovita - Si ha! Si ainda ha feiticeiras!

Onde - disse Vera.

Jovita - Oh! Gente! Não é tão longe assim! Ali mesmo no caminho do Corrego mora a tia Eva. Dizem que ella é bruxa.

Vera - É?!!!

Stella - Vamos pedir a mamãe para ir ao Corrego?

É, brinquem com ella, p'ra vê só!

A mulata afastou-se resmungando. (p. 141-146)

\section{OS DOCES DA TIA JOVITA}

Dali a dias seria o anniversario de Marcello. Este parecia ter criado juízo com os oito annos que ia completar, e, para recompensa-lo, cada qual por seu lado, em segredo, Ihe prepararia um presente.

Marcello tinha sua quéda pelas gulodices; mas, entre todas, a que elle preferia, era a cocada de abobora feita pela tia Jovita. E, como a vovó sabia disso, chamou uma manhã a mulata e disse-Ihe: Tia Jovita, não se esqueça do dia de annos de Marcello; cuide das cocadas. 
No dia seguinte estavam os doces promptinhos, corados, seccando ao sol em cima de uma taboa.

Ruth bisbilhotou logo a cousa: O' gente! Gritou ella, passando para o collegio, vocês já viram, o que está seccando na janella?

'O que é?'

'Adivinhem. Olhe, Marcello; uma cousa que você gosta.'

'Cocada de abobora.'

'Acertou! I sso mesmo!'

'Em que janella está, Ruth?'

Mas Ruth já correra como uma ventania, cantarolando e sumindo-se depressa, depressa pela estrada à fora. o sol!'

A vovó chegou a janella. 'O' menina! gritou ella, ponha chapeu na cabeça; olhe

Mal a vovó entrou, Marcello começou a matutar sua idéa. Sentou-se na solleira da porta e ficou pensando. Crespo, que estava perto delle, bateu com o rabo, ganiu duas ou tres vezes como para convida-lo a brincar. Mas qual! Na cabeça de Marcello, só o que virava era o doce de abobora!

[...]

E, muito geitozinho, o garoto foi trepando, trepando. Chegou à altura da taboa e provou o doce! Provou até demais! Porém, como era muito esperto, que fez ele? Agarrou uma cocada, virou-a e, com o dedinho, foi raspando o doce de dentro, deixando só a crosta como se fora um combuquinha. Fez isso com outra, com mais outra e outra ainda. Depois, virou-as de novo direitinho, botou-as no logar, e ninguém percebia que ellas estavam ôcas. Quando a tia J ovita chegou, já Marcello estava longe a correr com Crespo! A cozinheira sem desconfiar sequer de tamanha arte, recolheu os doces. No dia seguinte, à hora da sobremesa, veiu o doce de côco, veiu a goiabada, vieram muitos doces; afinal, como não chegassem as cocadas, a vovó gritou para dentro:

'O' J ovita, ande com as cocadas!'

No fim de alguns minutos a preta appareceu à porta. Tinha numa das mãos o prato dos doces e, na outra, uma cocada ôca.

'Sinházinha! exclamou ella com uma cara assombrada, Sinházinha! Veja só, e advinhe se puder qual foi o capetinha que comeu o meu doce!'

'Oh!' disse a velha

'Ah!' gritaram as crianças

E foi um reboliço então!

'Deixa ver! Como foi? Quem fez isso?!'

'Eu é que não fui!' quatro!

J ovita - E não pense a senhora que foi só uma, não! Estão assim umas tres ou

O pessoal cercara a tia Jovita, a vovó e o prato de doces. Só Marcello não se mexera. A vovó olhou-o.

'E se eu disser que eu já sei quem foi o capetinha?'

Marcello abriu no pranto.

‘Pois também, vovó, soluçou elle, tia Jovita faz de propósito! Bota o doce na janella p'ra tentar a gente!'

'Ora, ora! resmungou a creada, onde é que o havia de pôr!'

Marcello soluçou tanto que a vovó teve que abraça-lo para não estragar a festa dos seus oito annos. Elle consolou-se, mas tinha merecido um castigo, e castigado ficou. Os outros comeram as cocadas, elle ficou só com as quatro combuquinhas ôcas que tanto quizera provar! (p. 157-162) 


\section{ATÉ PARA O ANNO}

(...)

As meninas de D. Genoveva primeiro. Na vespera da viagem, despediram-se de tudo. Da parreira, do jardim, dos patos e tambem da Anna, da Zelinda e da tia Jovita. Esta enxugou os olhos na ponta do avental e entregou a Verinha umas latas de goiabada.

Para todas, hein?... recommendou ella. E não vão brigar!

Obrigada tia Jovita. Não se esqueça de nós ouviu?!

Não esqueço, não! E vocês vejam lá se aprendem tanta cousa para não escrever às velhas!

Nós havemos de escrever, sim, prometteu Stella.

[...]

Lá pelo meio dia, como sempre, chegou o correio. Ao ouvi-lo chegar, D. Clemência gritou para a cozinha: J ovita! olhe o correio. Veja si tem carta! pequenino.

Está aqui Sinházinha! disse a preta, entregando à velha um enveloppe

A velhinha abriu-o e deixou transparecer um sorriso.

É de Verinha... O' J ovita, é uma novidade! Ouça! 'Vovó, eu mando um beijo para a senhora, outro para Crespo, outro para a tia Jovita. Estou muito contente, por que aqui em casa ha tres cousas novas: um gato, uma boneca e uma irmãzinha que eu gosto mais! Parece uma bolinha e chama-se Thereza...' Mais uma para o anno, tia Jovita! rematou contente, a vovó.

A preta riu-se.

Está aqui, estamos de novo no verão, Sinházinha! Olhe, diga a Verinha que a tia Jovita já vai preparar a cama p'ra irmãzinha, o borralho p'ro gato e os trapos p'ra bruxinha!... (p. 180-184)

“A Mãi Preta” in: A Mãi de Família. Rio de Janeiro, Novembro de 1888. apud Sonia Maria Giacomini. Mulher e Escrava: uma introdução histórica ao estudo da mulher negra no Brasil. Rio de Janeiro, Vozes, 1988.

“... bendiziam aquelles que Ihes davam o pão para alimento e o duro trabalho para amenidade de suas vidas. Mãi preta foi uma dessas creaturas; sua vida porém não deve ficar no olvido, pois que symbolisa a existência de um'alma dotada de sentimentos extraordinariamente nobres." (p. 63)

“... tendo nascido a almejada criança, foi a filha preta levada para Róda, e, como a pobre mãi chorasse por essa separação brusca, foi de novo barbaramente castigada; mas como o seu coração era accessivel ao carinho, o vagido da recém nascida Ihe tocou n'alma, e assim também o soffrimento de sua senhora: esquecendose do mal que the faziam pelo bem que ia prestar, tomou a criancinha, chegou-a ao seio e amamentou-a devotamente...". (p. 63) 